MARIA AUGUSTA ALONSO

Efeito da aplicação da hCG em diferentes dias do ciclo estral sobre a concentração sérica de progesterona e fluxo sanguíneo uterino e ovariano em éguas 


\section{Efeito da aplicação da hCG em diferentes dias do ciclo estral sobre a concentração sérica de progesterona e fluxo sanguíneo uterino e ovariano em éguas}

Tese apresentada ao Programa de Pós-
Graduação em Reprodução Animal da
Faculdade de Medicina Veterinária e Zootecnia
da Universidade de São Paulo para a obtenção
do título de Doutor em Ciências

Departamento:

Reprodução Animal

Área de concentração:

Reprodução Animal

Orientador:

Prof. Dr. Rubens Paes de Arruda

São Paulo 
Autorizo a reprodução parcial ou total desta obra, para fins acadêmicos, desde que citada a fonte.

DADOS INTERNACIONAIS DE CATALOGAÇÃO-NA-PUBLICAÇÃO

(Biblioteca Virginie Buff D’Ápice da Faculdade de Medicina Veterinária e Zootecnia da Universidade de São Paulo)

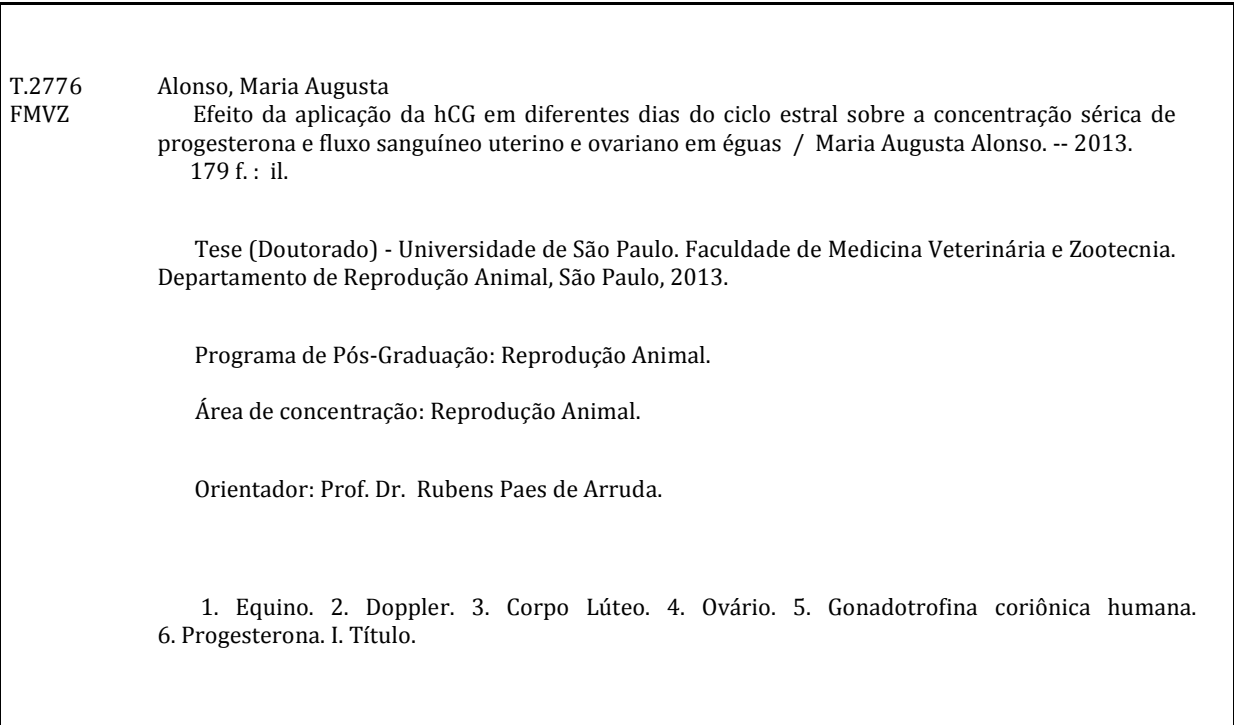




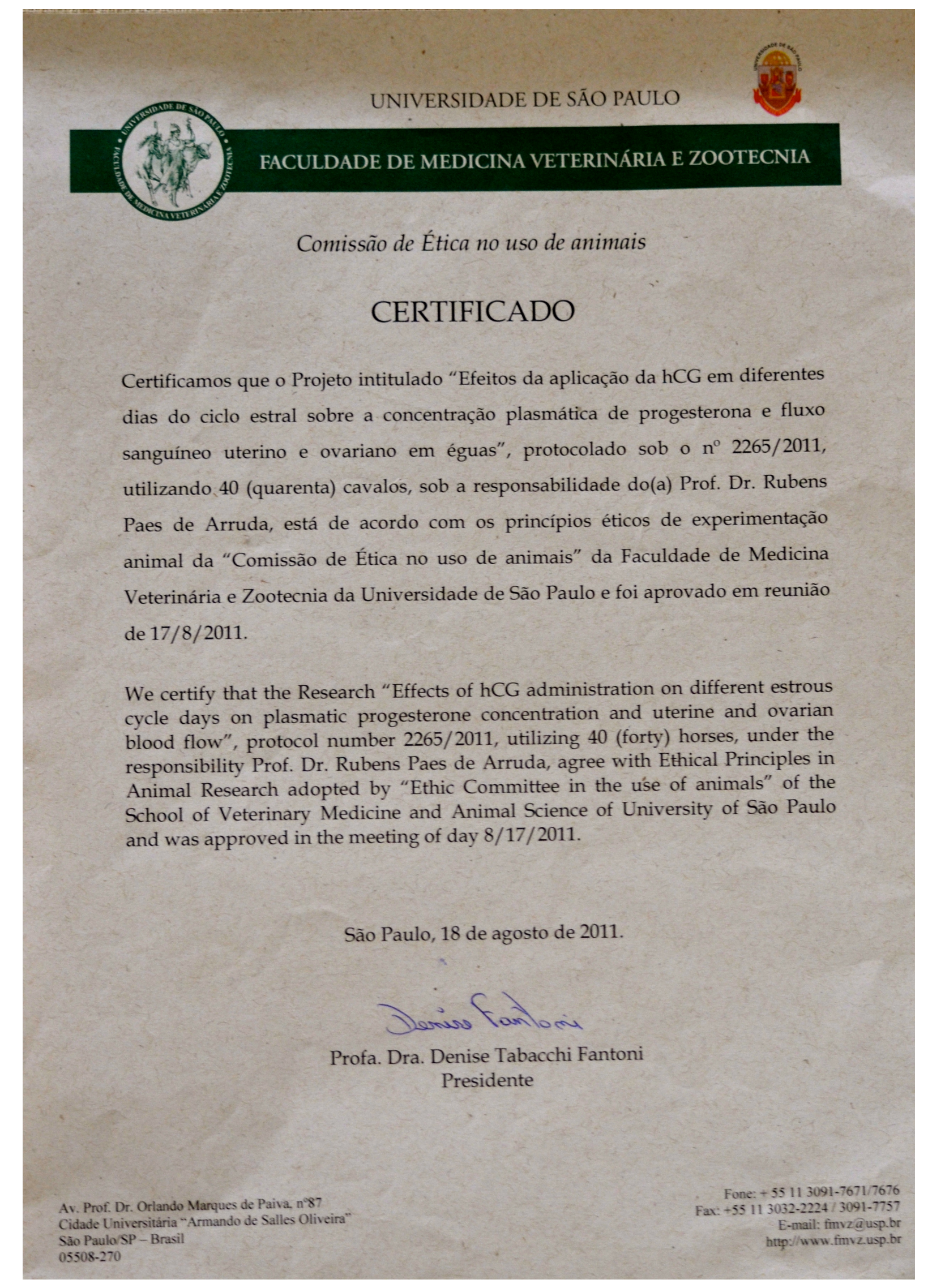




\section{FOLHA DE AVALIAÇÃo}

Nome: ALONSO, Maria Augusta

Título: Efeito da aplicação da hCG em diferentes dias do ciclo estral sobre a concentração sérica de progesterona e fluxo sanguíneo uterino e ovariano em éguas

Tese apresentada ao Programa de PósGraduação em Reprodução Animal da Faculdade de Medicina Veterinária e Zootecnia da Universidade de São Paulo para a obtenção do título de Doutor em Ciências

Data:

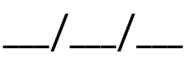

\section{Banca Examinadora}

Prof. Dr.

Instituição:

Julgamento:

Prof. Dr.

Instituição:

Julgamento:

Prof. Dr.

Instituição:

Julgamento:

Prof. Dr.

Instituição:

Julgamento:

Prof. Dr.

Instituição:

Julgamento: 


\title{
DEDICATÓRIA
}

\author{
"Teaching consists of causing or \\ allowing people to get into \\ situations from which they cannot \\ escape except by thinking"
}

Dedico minha tese ao João (in memoriam), que me acompanha em todos os dias da minha vida na reprodução, em memória e como exemplo. A você João, obrigada por ter guiado meu primeiro passo na Reprodução Equina e ser uma inspiração que ilumina o caminho. 


\section{AGRADECIMENTOS}

Como sempre, devo agradecer ao meu pai. Sempre ao meu lado em todas as situações, e acreditando no meu potencial. Os puxões de orelha nas horas certas e outras nem tanto... as oportunidades que me ofereceu e oferece todos os dias... a devoção total ao papel de pai, com tudo que a palavra PAI significa... Muito obrigada por tudo mais uma vez e me desculpe pelas teimosias e discussões...

À minha mãe, por estar agora longe fisicamente, mas mais perto do meu coração...

À Pata, que sempre prezou pela minha felicidade e a da nossa família. Sempre é meu modelo sendo uma profissional excepcional e de ética irreparável. Por me mostrar que temos sempre que olhar para o outro e oferecer não o que esperamos receber, mas sim o que o outro realmente precisa. Pelo ensinamento de falar pelos cavalos quando eles não podem fazê-lo e protegê-los sempre.

Ao Zé, meu companheiro de muitos anos na linda arte de cuidar de cavalos... meu melhor amigo... meu amor...meu colo...e acima de tudo, minha calma.... Obrigada por me dar broncas quando eu preciso e me acalmar quando a ansiedade me mata.... Ao seu lado, eu sou uma pessoa melhor.

À Mari! Minha irmã querida! Não tenho como expressar em palavras... o que temos é meu bem mais precioso... você sabe... Pedro Augusto e Maria Fernanda, meus sobrinhos amados!! Aos meus tios Bellini e Dadá, que me integraram na sua família e aquecem meu coração com muito amor e carinho.

Ao Fer e a Fê, que ficaram ao meu lado todos os dias para tornar possível um sonho. Por terem sido meus braços direito e esquerdo, e me divertirem nas horas mais cansativas... Eu não tenho como agradecer a vocês pela grande ajuda e amizade!

A Flor e ao Gui, que me acompanharam na pior fase da vida, de maiores dificuldades e dores... São amigos para todas as horas! Amo vocês! 
À Sofie, que se tornou uma grande amiga e ficou ao meu lado quando tudo parecia desmoronar... Me ajudou a ficar em pé e continuar trabalhando....

À Juju Nascimento por todas as ajudas (e olha que foram muitas) e pela grande amizade que construímos dia a dia, e que cresce cada vez mais. Você sempre esteve ao meu lado com um sorriso no rosto! Te admiro muito como pessoa e profissional. Aprendi e aprendo muito com você. Sinto sua falta aqui com a gente!

À Soninha, por estes 18 anos ao meu lado. Por ser muito mais do que terapeuta... Por realmente se preocupar em me tornar uma pessoa feliz e estar ao meu lado nos momentos mais difíceis!

À Perla por ser minha amiga querida apesar da distância. Por ter me dado a primeira chance profissional e ter confiado na minha capacidade. Não terei nunca como te agradecer...

À minha irmã/filha, Julia que me faz rir com seus "Meus que me livres" e sorrir com seus abraços ao som de "te amo minha irmã".

À Ju, que mesmo do lado de cima do continente me diverte com suas ligações cômicas com histórias hilárias e discussões de papers! Você faz muita falta por aqui!

À Hilda e Terezinha por cuidarem de mim como da própria família e estarem do meu lado ao longo de toda a minha vida!

À Helô, Dra Letícia, Rô e Dr. Ivan que me recuperaram incansavelmente das dores no punho e ombro e tornaram a realização deste experimento possível, pelo carinho com que me trataram e por ter novamente um corpo saudável! 
Em especial ao Professor Rubens, meu orientador desde o tempo da graduação... Esteve ao meu lado desde o começo, acreditou em mim, e sempre me deu grandes oportunidades, ensinamentos como pessoa e como educador. E sempre corrigiu meus erros, para me colocar no caminho correto. Obrigada pela oportunidade de realizar meu doutorado e continuar com a minha paixão pelo ensino.

Ao Luciano, pela coorientação, pela disponibilidade e atenção com que sempre me atendeu. Por me ajudar pacientemente com as minhas dúvidas e questionamentos intermináveis.

Ao Professor Marco Alvarenga, que foi responsável pelo início inusitado no mundo acadêmico, que me abriu tantas portas e me levou a tantos caminhos novos e maravilhosos.

À Professora Cláudia, pela amizade, companheirismo e confiança e por me dar a chance de ficar ao seu lado nesta bela caminhada que é a pesquisa!

Ao Kléber, meu querido amigo e verdadeiramente indispensável! Sem você, não teríamos chegado até aqui.... Com muito trabalho e amizade nós passamos ótimos e produtivos dias juntos.

À Joanna, que foi fundamental para que a primeira etapa do experimento fosse realizada. Muitíssimo obrigada!

À Dea, que de forma tão fraternal me doou seus preciosos dias, sorrisos, palpações e colo e que me mostrou como realmente conhecemos os verdadeiros amigos. Muito, muito mesmo obrigada!

Ao Henrique e ao Milton, meus amigos de longe mas no coração sempre perto! 
Aos meus estagiários que diretamente auxiliaram no meu experimento: Naty, Danilo, Thiago, Paloma e Ju!

Ao Reno, por ter me ajudado no início Doppler da minha vida, que se dispôs a ficar aqui me ensinando!

Aos amigos do VRA que sempre estão ao meu lado para tudo, sobretudo dispostos a ajudar e passar bons momentos: Carol, João, Carina, Simprão, Simone, Paty, Lili, Samir, Primo, Manolo, Henderson, Robertinha, Andres, Zé Rodrigo, Aline, Lindsay, Moana, Milena, Saara, André (tóxico), Arroz, Roberta, Andrezza, Rodrigos, Paulão, Mari, Fernanda, Robinson, Rafaela, Julia, Marcão, Dominique, Kedson, Andrezza, João Diego, Daniel, Cris, Liege, Carina, Marcela...

À Priscila Viau e a todos do LDH, pelo auxílio nas mensurações de progesterona.

A todos os meus estagiários ao longo do tempo, que seria injusto citar um e esquecer de alguém!

A minha vó Elza e minha madrinha, por sempre se preocuparem e cuidarem de mim.

À vó Zezé e o vô Geraldo (in memoriam)! Meus avós queridos que fazem muita falta!

Ao Dr. Patrick McCue que me orientou nos primeiros experimentos, me deu a primeira oportunidade de pesquisa e me encantou por ensinar.

Aos professores da minha vida toda, não só na faculdade, como também na escola! 
Aos Professores do Departamento de Reprodução da FMVZ-USP, pelas aulas, conversas e valiosas idéias trocadas.

À Harumi que sempre me auxiliou com minhas dúvidas burocráticas.

À Neuza e à Elza da biblioteca que me ajudaram nas correções da parte de normalização.

À todos os outros amigos que fizeram ou fazem parte da minha vida.

Aos cavalos, que são os responsáveis pela opção pela Medicina Veterinária e pela Reprodução. Que enchem meus dias de alegria e sentimento de tarefa cumprida... Cada relincho, cada galope me fazem ter mais certeza de que faço a única coisa que me faria feliz!

Em especial à Ruiva, Pedrita, Pedrês, Balalaica, Geometria, Gaia, Mancha, Gaúcha, Anabela, Nala, Árabe e Raiz por terem sido anjos durante todo o tempo no experimento...

Agradeço à FAPESP pelo apoio financeiro, pelo Auxílio e pela bolsa que permitiram a realização deste projeto. 


\section{RESUMO}

ALONSO, M. A. Efeito da aplicação da hCG em diferentes dias do ciclo estral sobre a concentração sérica de progesterona e fluxo sanguíneo uterino e ovariano em éguas. [Effect of hCG administration in different days of the estrous cycle on serum progesterone concentration and uterine and ovarian blood flow in mares]. 2013. $179 \mathrm{f}$. Tese. (Doutorado em Ciências) - Faculdade de Medicina Veterinária e Zootecnia, Universidade de São Paulo, São Paulo, 2013.

A aplicação de drogas durante o diestro para melhorar a taxa de prenhez na égua inseminada e na receptora de embrião tem sido o foco de alguns grupos de pesquisa. Estudos com hCG encontraram resultados promissores nas taxas de prenhez e características uterinas de receptoras de embrião no dia da transferência. Com o objetivo de avaliar o efeito da aplicação da hCG em diferentes momentos do ciclo estral sobre as características do trato reprodutivo, vascularização e concentração sérica de progesterona, os animais foram submetidos à aplicação da hCG para induzir ovulação, no dia da ovulação e no $5^{\circ}$ dia pós ovulação, além do grupo controle. 0 presente trabalho foi dividido em estudo preliminar com 4 animais em cada grupo e um estudo principal, com 12 animais por grupo sendo que todos os animais foram submetidos a todos os tratamentos. As características examinadas ao longo dos 15 dias pós ovulação foram tônus, morfoecogenicidade e vascularização do útero; tônus da cérvix; o diâmetro e área do corpo lúteo e do pedículo ovariano e seu RI; RI e vascularização mesometrial. Além disso, amostras de sangue para mensuração sérica de progesterona foram coletadas. Não foi encontrado efeito do tratamento nas características avaliadas com hCG em nenhum dos grupos. As características somente apresentaram variação ao longo do tempo, conforme descrito na literatura. Novos estudos avaliando o efeito da hCG em éguas devem ser realizados para averiguar outras variáveis e possíveis efeitos.

Palavras-chave: Equino. Doppler. Corpo Lúteo. Ovário. Gonadotrofina Coriônica Humana. Progesterona 


\begin{abstract}
ALONSO, M. A. Effect of hCG administration in different days of the estrous cycle on serum progesterone concentration and uterine and ovarian blood flow in mares. [Efeito da aplicação da hCG em diferentes dias do ciclo estral sobre a concentração sérica de progesterona e fluxo sanguíneo uterino e ovariano em éguas]. 2013. 179 f. Tese. (Doutorado em Ciências) - Faculdade de Medicina Veterinária e Zootecnia, Universidade de São Paulo, São Paulo, 2013.
\end{abstract}

The use of drugs during diestrus in order to improve conception rates in inseminated and recipient mares has been the focus of several research groups. Studies using hCG found promising results regarding pregnancy rates and recipient uterine characteristics on the Day of the transfer. The objective of the study was to evaluate the effect of hCG administration in different moments of the oestrous cycle on reproductive tract characteristics, vascularization and serum progesterone concentration. Therefore, groups consisted of control, hCG to induce ovulation; hCG on day 0 and hCG on day 5 postovulation. The current study was performed as a preliminar study with 4 animals per group, one cycle each animal and a main study with 12 animals per group, each animal receiving all the treatments during consecutive cycles. The evaluations were performed daily from day 0 until day 15 postovulation. Characteristics examined were uterine tone, morphoecogenicity and vascularization; cervical tone; area, diamaterand vascularization of the corpus luteum, ovarian pedicle vascularization and RI; mesometrial vascularization and RI. Besides, blood samples were collected for serum progesterone concentration. No diferences were detected comparing treated and control groups. The characteristics only varied through the days, as described in the literature. Therefore, it can be concluded that hCG administered to induce ovulation, on the day of ovulation and on day 5 postovulation did not alter the characteristics evaluated in the current study.

Keywords: Equine. Doppler. Corpus Luteum. Ovary. Human Chorionic Gonadotrophin. Progesterone 


\section{LISTA DE ILUSTRAÇÕES}

Figura 1 - Vascularização do CL....................................................................................103

Figura 2 - Escores de vascularização do pedículo ovariano.......................................104

Figura 3 - Escores de vascularização do endométrio..................................................105

Figura 4 - Escores de vascularização do mesométrio...................................................105 


\section{LISTA DE GRÁFICOS}

Gráfico 1- Média \pm erro padrão do escore de morfoecogenicidade uterina das éguas nos diferentes tratamentos entre os dias 0 a 15 pós ovulação

Gráfico 2- Média \pm erro padrão do escore do tônus uterino das éguas nos diferentes tratamentos entre os dias 0 a 15 pós ovulação

Gráfico 3 - Média \pm erro padrão do escore do tônus cervical das éguas nos diferentes tratamentos entre os dias 0 a 15 pós ovulação.

Gráfico 4 - Média \pm erro padrão da área do corpo lúteo das éguas nos diferentes tratamentos entre os dias 0 a 15 pós ovulação

Gráfico 5 - Média \pm erro padrão do diâmetro do corpo lúteo das éguas nos diferentes tratamentos entre os dias 0 a 15 pós ovulação

Gráfico 6 - Média \pm erro padrão da porcentagem de vascularização do corpo lúteo das éguas nos diferentes tratamentos entre os dias 0 a 15 pós ovulação.

Gráfico 7- Média \pm erro padrão do escore de vascularização do pedículo ovariano das éguas nos diferentes tratamentos entre os dias 0 a 15 pós ovulação

Gráfico 8 - Média \pm erro padrão do escore de vascularização do endométrio das éguas nos diferentes tratamentos entre os dias 0 a 15 pós ovulação.

Gráfico 9 - Média \pm erro padrão do escore de vascularização do mesométrio contralateral nas éguas nos diferentes tratamentos entre os dias 0 a 15 pós ovulação. 
Gráfico 10- Média \pm erro padrão do escore de vascularização do mesométrio ipsilateral ao corpo lúteo nas éguas nos diferentes tratamentos entre os dias 0 a 15 pós ovulação

Gráfico 11 - Média \pm erro padrão da concentração sérica de progesterona nas éguas nos diferentes tratamentos entre os dias 0 a 15 pós ovulação

Gráfico 12 - Média \pm erro padrão da concentração sérica de progesterona nas éguas com ovulação simples e dupla nos diferentes tratamentos entre os dias 0 a 15 pós ovulação

Gráfico 13- Média \pm erro padrão do escore de morfoecogenicidade uterina das éguas nos diferentes tratamentos entre os dias 0 a 15 pós ovulação

Gráfico 14- Média \pm erro padrão do escore de tônus uterino das éguas nos diferentes tratamentos entre os dias 0 a 15 pós ovulação

Gráfico 15 - Média \pm erro padrão do escore de tônus cervical das éguas nos diferentes tratamentos entre os dias 0 a 15 pós ovulação.

Gráfico 16 - Média \pm erro padrão da área do corpo lúteo das éguas nos diferentes tratamentos entre os dias 0 a 15 pós ovulação. 126

Gráfico 17 - Média \pm erro padrão do diâmetro do corpo lúteo das éguas nos diferentes tratamentos entre os dias 0 a 15 pós ovulação

Gráfico 18 - Média \pm erro padrão da porcentagem de vascularização do corpo lúteo das éguas nos diferentes tratamentos entre os dias 0 a 15 pós ovulação

Gráfico 19 - Média \pm erro padrão do escore de vascularização do pedículo ovariano das éguas nos diferentes tratamentos entre os dias 0 a 15 pós ovulação 
Gráfico 20 - Média \pm erro padrão do índice de resistência do pedículo ovariano das éguas nos diferentes tratamentos entre os dias 0 a 15 pós ovulação

Gráfico 21 - Média \pm erro padrão do escore de vascularização do endométrio das éguas nos diferentes tratamentos entre os dias 0 a 15 pós ovulação

Gráfico 22 - Média \pm erro padrão do escore de vascularização do mesométrio nas éguas nos diferentes tratamentos entre os dias 0 a 15 pós ovulação

Gráfico 23 - Média \pm erro padrão do índice de resistência do mesométrio nas éguas nos diferentes tratamentos entre os dias 0 a 15 pós ovulação 133

Gráfico 24 - Média \pm erro padrão daconcentração sérica de progesterona nas éguas nos diferentes tratamentos entre os dias 0 a 15 pós ovulação 


\section{LISTA DE TABELA}

Tabela 1- Sensibilidade, dose mínima detectável, coeficiente de variação intra ensaio e coeficiente de variação inter ensaio dos ensaios de progesterona - São Paulo - 2012 


\section{LISTA DE ABREVIATURAS E SIGLAS}

$\begin{array}{ll}\text { CH } & \text { corpo hemorrágico } \\ \text { CL } & \text { corpo lúteo } \\ \text { cm/s } & \text { centímetro por segundo } \\ \text { d 0 } & \text { dia da ovulação } \\ \text { d 5 } & \text { quinto dia pós ovulação } \\ \text { d } & \text { dia } \\ \text { D2 } & \text { receptor de dopamina 2 } \\ \text { Da } & \text { Dalton } \\ \text { DNA } & \text { ácido desoxiribonucleico } \\ \text { EDV } & \text { velocidade no pico diastólico } \\ \text { EGF } & \text { fator de crescimento epidermal } \\ \text { eNOS } & \text { oxido nítrico sintase endotelial } \\ \text { FGF } & \text { fator de crescimento fibroblástico } \\ \text { FSH } & \text { hormônio folículo estimulante } \\ \text { g } & \text { grama } \\ \text { GH } & \text { hormônio do cresciemnto } \\ \text { GnRH } & \text { hormônio liberador de gonadotrofina } \\ \text { h } & \text { hora } \\ \text { hCG } & \text { gonadotrofina coriônica humana } \\ \text { HDL } & \text { lipoproteína de alta densidade } \\ \text { Hz } & \text { hertz } \\ \text { IGF } & \text { fator tipo insulina } \\ \text { LDL } & \text { oxido nítrico sintase induzida } \\ \text { min } & \text { lipoproteína de baixa densidade } \\ \text { milititro por grama por minuto }\end{array}$




$\begin{array}{ll}\text { mm } & \text { milímetro } \\ \text { ng } & \text { nanograma } \\ \text { ON } & \text { óxido nítrico } \\ \text { P450c17 } & \text { esteróide 17alfa hiroxilase/17,20 liase } \\ \text { P450scc } & \text { enzima clivadora da cadeia lateral de colesterol } \\ \text { PGE }_{2} & \text { prostaglandina E } \\ \text { PGF }_{2 \alpha} & \text { Prostaglandina F 2alfa } \\ \text { PI } & \text { índice de pulsatilidade } \\ \text { PKA } & \text { proteína quinase A } \\ \text { PRA } & \text { receptor de progesterona A } \\ \text { PRB } & \text { receptor de progesterona B } \\ \text { PRL } & \text { prolactina } \\ \text { PSI } & \text { Puros Sangue Inglês } \\ \text { PSV } & \text { velocidade no pico sistólico } \\ \text { r } & \text { raio } \\ \text { RI } & \text { índice de resistividade } \\ \text { SCP-2 } & \text { proteina 2 carreadora de esterol } \\ \text { SR-BI } & \text { receptor scavenger classe B tipo 1 } \\ \text { StAR } & \text { proteína esteroidogênica reguladora aguda } \\ \text { TAMV } & \text { média das velocidades máximas } \\ \text { TE } & \text { transferência de embrião } \\ \text { VEGF } & \text { fator de crescimento vascular endotelial } \\ & \end{array}$




\section{LISTA DE SÍMBOLOS}

$\begin{array}{ll}\% & \text { porcentagem } \\ < & \text { menor } \\ > & \text { maior } \\ \pm & \text { mais ou menos } \\ { }^{\circ} & \text { grau } \\ { }^{\circ C} & \text { graus Celsius } \\ \text { X } & \text { vezes } \\ \alpha & \text { alfa } \\ \beta & \text { beta } \\ \Pi & \text { pi }\end{array}$




\section{SUMÁRIO}

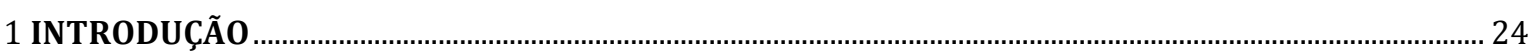

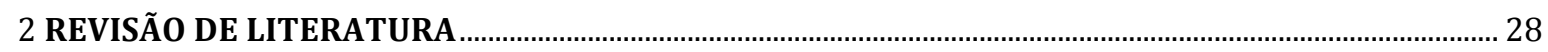

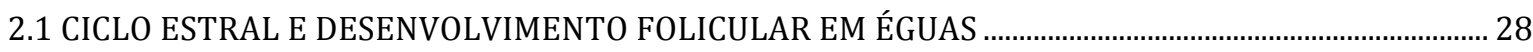

2.2 ALTERAÇÕES DO ÚTERO E CÉRVIX AO LONGO DO CICLO ESTRAL …………………………………....... 38

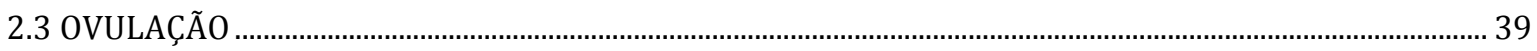

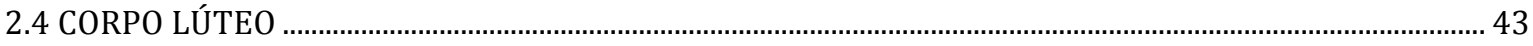

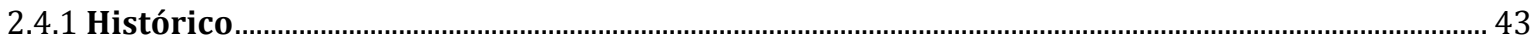

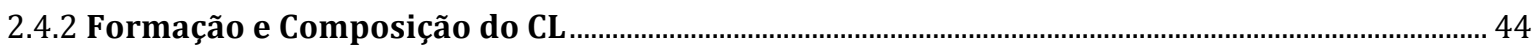

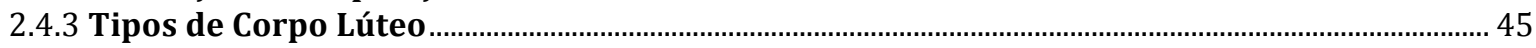

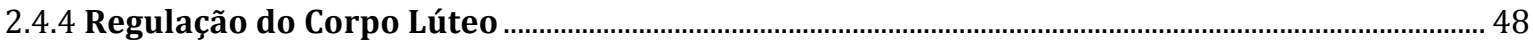

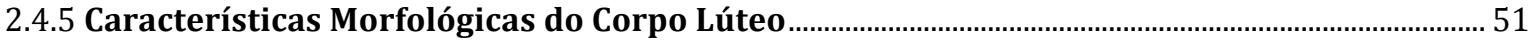

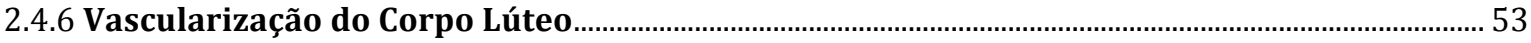

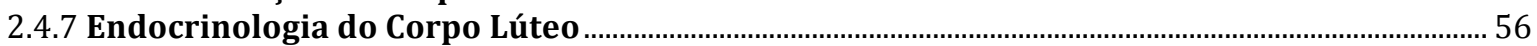

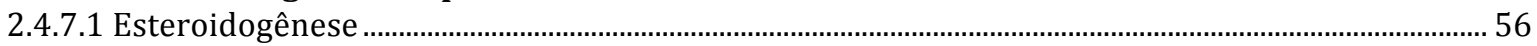

2.4.8 Alteração da Função Luteal............................................................................................................. 59

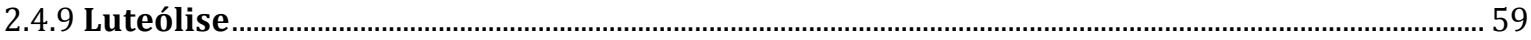

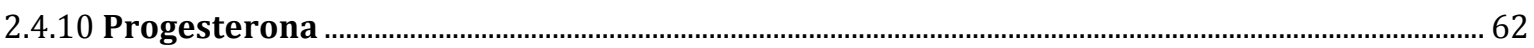

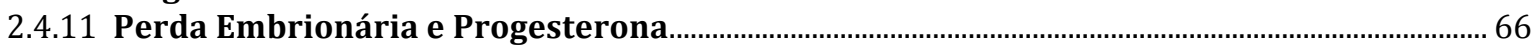

2.5 GONADOTROFINA CORIÔNICA HUMANA (hCG) ................................................................................................ 69

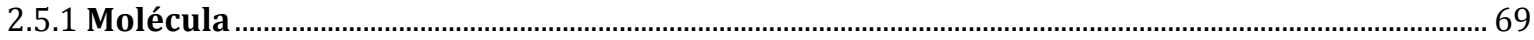

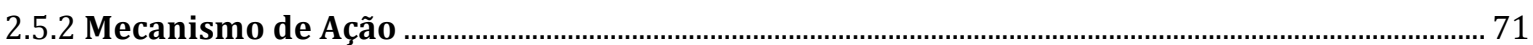

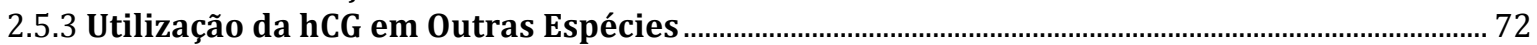

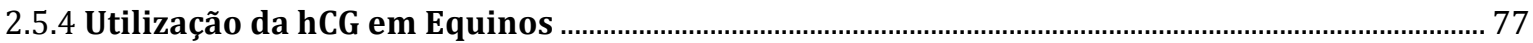

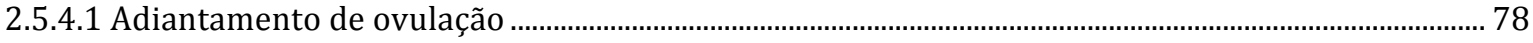

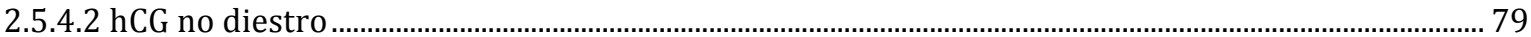

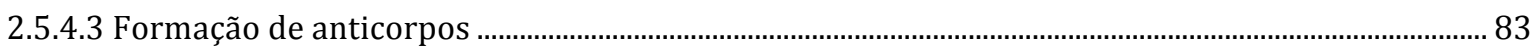

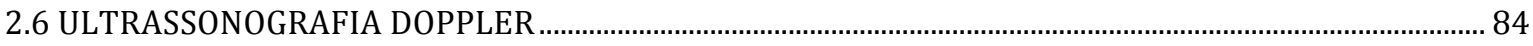

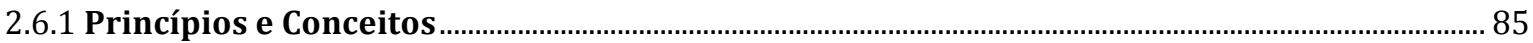

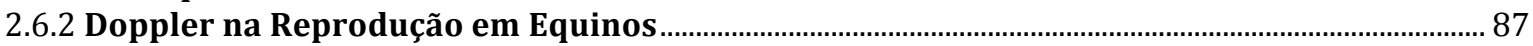

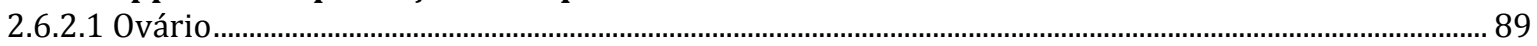

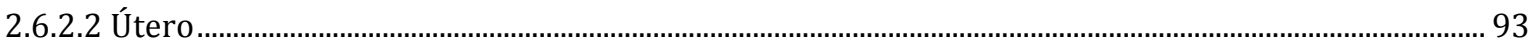

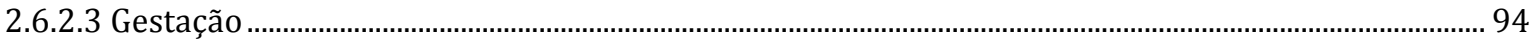

3 HIPÓTESES

4 OBJETIVOS

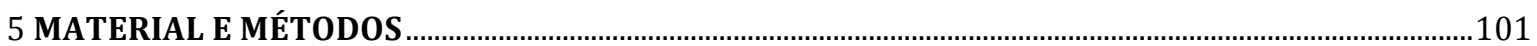

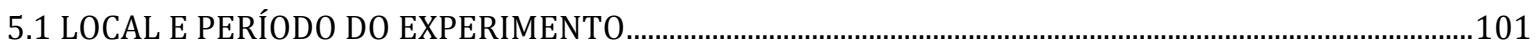

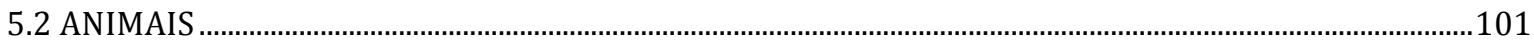

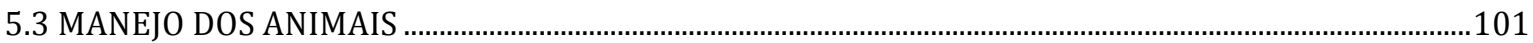

5.4 DELINEAMENTO EXPERIMENTAL ..............................................................................................................102

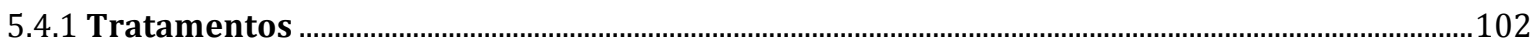

5.4.2 Avaliação do Sistema Reprodutivo ………………………………………………………………....103

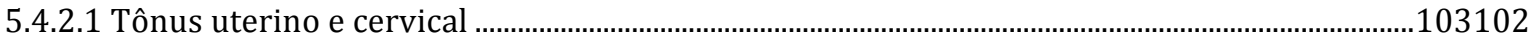

5.4.2.2 Avaliação ultra-sonográfica utilizando modo B...................................................................................103

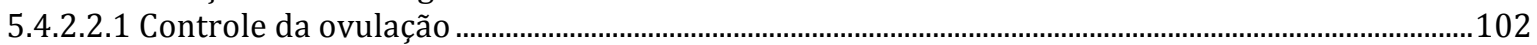




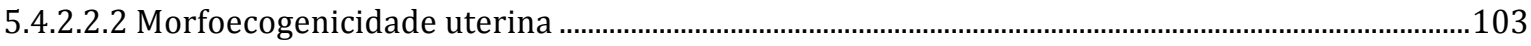

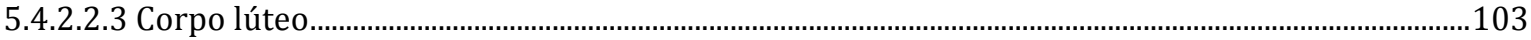

5.4.2.3 Avaliação ultra-sonográfica utilizando doppler colorido..................................................................105

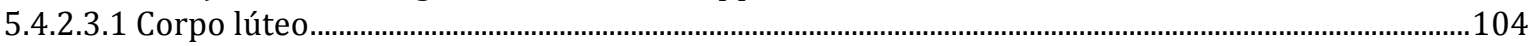

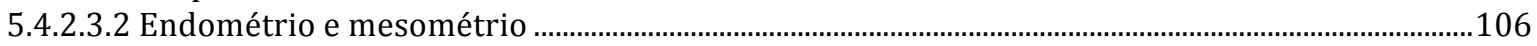

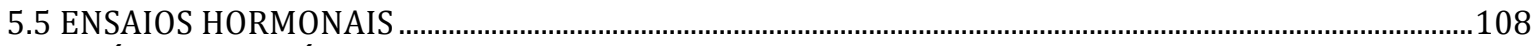

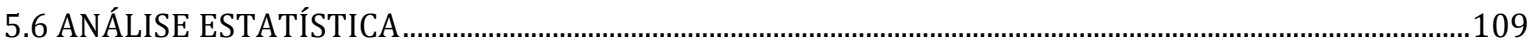

6 RESULTADOS ...................................................................................................................................112

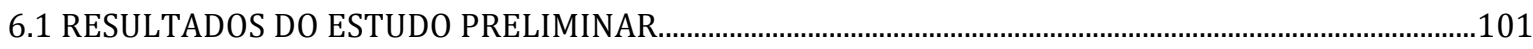

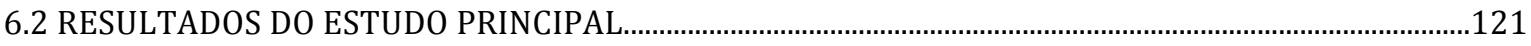

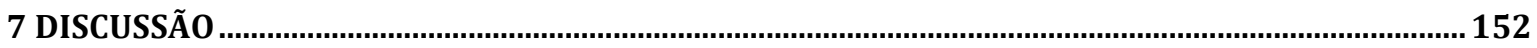

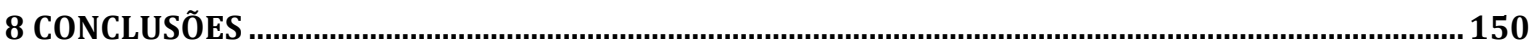

REFERÊNCIAS 


\section{INTRODUÇÃO}

O cavalo possui um aspecto de produção e animal de companhia, tornando seu papel na sociedade duplamente importante. A população de equídeos atinge cerca de oito milhões no Brasil, sendo 5 milhões e 560 mil equinos, conferindo a quarta colocação ao país no cenário mudial, atrás apenas de EUA, México e China. 0 mercado relacionado aos eqüinos gira $\mathrm{R} \$ 7,5$ bilhões, com 3,2 milhões de empregos diretos e indiretos (ALMEIDA; SILVA, 2010; IBGE, 2010).

$\mathrm{Na}$ área de Reprodução especificamente, um levantamento realizado por Stroud e Callesen (2012) estimou que 41652 coletas de embrião foram realizadas no mundo em 2010 , um crescimento de $13 \%$ em relação ao ano anterior e $42 \%$ a mais do que em 2008 , mostrando claramente um aumento da utilização da técnica. O Brasil passou a ocupar o primeiro lugar com $43 \%$ do número de embriões transferidos, sendo que Argentina (29\%) e EUA (19\%) ocupam a segunda e terceira colocação, respectivamente.

Quando consideramos que a égua é, na maioria das vezes, um animal monovulatório e estacional, fazendo com que o número de ciclos e ovulações utilizados por ano seja limitado, fica mais evidente a importância de uma máxima eficiência reprodutiva nas gestações naturais e TE (transferência de embrião). Entretanto, o valor sentimental atribuído ao cavalo torna a abordagem um pouco diferente dos outros animais de produção, tendo um aspecto individual e não de rebanho, o que confere a cada gestação, potro ou perda embrionária uma importância muito maior do que meramente financeira.

Visto que o objetivo da criação é a produção de potros, bons índices reprodutivos de taxa de prenhez por ciclo, taxa de prenhez ao final da estação de monta, taxa de recuperação embrionária, taxa de prenhez pós transferência de embrião e baixa taxa de perda embrionária são imperativos para que a máxima eficiência seja atingida. Desta forma, o incremento destes índices de uma forma geral tem sido o objeto de pesquisas ao longo dos anos, abrangendo aspectos relativos ao sêmen, ao trato reprodutivo da égua e à manipulação farmacológica do ciclo estral (adiantamento da estação reprodutiva, aplicação de drogas para melhoria da taxa de prenhez e protocolos de superovulação). 
A aplicação de drogas durante o diestro para melhorar a taxa de prenhez na égua inseminada ou na receptora de embrião tem sido estudada nos últimos anos. Análogos do GnRH como a buserelina (PYCOCK; NEWCOMBE 1996; NEWCOMBE; MARTINEZ; PETERS, 2001; KANITZ et al., 2007) e a deslorelina (MCCUE et al., 2012) e a gonadotrofina coriônica humana (hCG) (FLEURY, 2004) levaram a resultados nas taxas de prenhez promissores. Além disso, a utilização da hCG no dia da ovulação e no dia 1 pós ovulação aumentou a porcentagem de receptoras que apresentam características uterinas e cervicais desejáveis no dia 6 pós ovulação (SOUZA, 2006).

Desta forma, este estudo tem como objetivo estudar os efeitos da aplicação da hCG em diferentes momentos do ciclo estral sobre as dimensões e fluxo sanguineo do corpo lúteo, tônus cervical e tônus, morfoecogenicidade e vascularização do útero, além do efeito na concentração sérica de progesterona em éguas. 
Revisão de Literatura 


\section{REVISÃO DE LITERATURA}

Ao longo da revisão de literatura serão abordados temas referentes ao assunto pesquisado, com o intuito de prover informações para justificar e discutir os materiais e métodos e resultados do presente trabalho.

\subsection{CICLO ESTRAL E DESENVOLVIMENTO FOLICULAR EM ÉGUAS}

A Terra sofre ao longo do ano um aquecimento e resfriamento devido a sua rotação ao redor do sol (SHARP, 2011). Ao longo da evolução, adaptações ocorreram para que os descendentes das espécies nascessem no momento apropriado do ano (AURICH, 2011), sendo que as éguas que pariam no período frio, sem alimento disponível não conseguiam passar seus genes (SHARP, 2011). No cavalo, a mudança do fotoperíodo é considerada a principal responsável pelo ritmo circanual reprodutivo (GINTHER, 1992; NAGY; GUILLAUME; DAELS, 2000), garantindo que o nascimento ocorra na primavera e verão. A mudança no período de luz diário é um sinal ambiental codificado pelo olho para um sinal endócrino na pineal, que em resposta à escuridão irá secretar melatonina (NAGY; GUILLAUME; DAELS, 2000).

Éguas são geralmente animais poliéstricos estacionais com atividade ovulatória relacionada aos dias longos e noites curtas (PALMER; GUILLAUME, 1992; HAFEZ; HAFEZ; 2000). 0 fotoperíodo não é, entretanto, o único responsável por esta regulação, tendo outros fatores tais como idade, status reprodutivo, nutrição, condição corporal e temperatura, influência na atividade reprodutiva (NAGY; GUILLAUME; DAELS, 2000; SESSIONS et al., 2004). Uma proporção de animais continua ciclando ao longo de todo o ano (AURICH, 2011) podendo produzir um potro em qualquer época (HAFEZ; HAFEZ, 2000), sendo essa atividade reprodutiva no período esperado de anestro reportada por vários grupos (FITZGERALD; SCHMIDT, 1995; DAVISON; MCMANUS; FITZGERALD, 1998; FITZGERALD; MCMANUS, 2000) e o motivo de sua ocorrência não é completamente compreendido. 
Entretanto notou-se que éguas com mais do que 5 anos têm mais chance de ciclar continuamente, provavelmente devido a um maior acúmulo de gordura, sendo uma forma de armazenamento de energia que pode alterar a ciclicidade. Por outro lado, a gestação e posterior lactação, situações de desafio energético, parecem favorecer o anestro, independente da idade (PALMER; DRIANCOURT, 1983; FITZGERALD; MCMANUS, 2000; KING, 2011). Animais bem nutridos e estabulados tendem a ciclar o ano todo (HAFEZ; HAFEZ, 2000), em especial éguas com escore de condição corporal entre 6 e 9, em uma escala na qual 1 significa um animal muito magro e 9 um animal obeso (HENNEKE et., 1983; FITZGERALD; MCCMANUS, 2000). Acredita-se que a seleção da criação também auxilia nessa diminuição da sazonalidade da atividade reprodutiva, pois a gestação deve ocorrer mais cedo na estação de monta, para tornar possível a entrada dos potros em competição precocemente. Nas raças de competição, cerca de $30 \%$ das éguas apresentam ciclos ovulatórios ao longo de todo o inverno (AURICH, 2011). A leptina é provavelmente o fator sinalizador do balanço energético e ela altera a resposta a diminuição do fotoperíodo e inibição pela melatonina (FITZGERALD; MCCMANUS, 2000).

Geralmente as éguas são monovulatórias, e esta característica permanece em animais menos domesticados, sendo as duplas ovulações pouco frequentes (GINTHER et al., 2001). Em éguas domesticadas, as taxas de dupla ovulação variam de 7 a $25 \%$ e são geralmente relacionadas a diversos fatores tais como raça, idade, status reprodutivo, manipulação farmacológica do ciclo estral e indivíduo. Em Pôneis sua frequência é de cerca de $2 \%$ a 3\% enquanto em Puro Sangue Inglês (PSI) varia entre 15 a 25\% (GINTHER, 1992). As ovulações duplas podem ser sincrônicas (até 12 horas de intervalo) ou assincrônicas, com intervalo de dois dias ou mais. Particularmente nos animais com duplas ovulações, a taxa de crescimento dos folículos dominantes é menor e consequentemente o diâmetro folicular também é menor. Acredita-se que os menores níveis de hormônio folículo estimulante (FSH) circulantes decorrentes da maior concentração de inibina e estradiol dos dois folículos pré ovulatórios sejam os responsáveis por esta característica de menor crescimento (GINTHER et al., 2008).

O ciclo estral ou intervalo interovulatório se inicia após a ovulação acompanhada de estro e termina com a próxima ovulação acompanhada de estro (BEG; BERGFELT, 2011), tendo uma duração média na primavera e verão de 21 (MCCUE; SCOGGIN; LINDHOLM, 2011) a 22 dias (HAFEZ; HAFEZ, 2000). A raça e o status reprodutivo afetam 
a duração do ciclo estral, sendo que as raças Pônei têm ciclo estral dois dias mais longo (AURICH, 2011) e éguas em lactação apresentam um ciclo estral médio de 21,2 $\pm 1,8$ dias comparado com 22,8 \pm 1,4 dias em não lactantes (HEIDLER et al., 2004).

O ciclo estral possui duas fases distintas tanto fisiológica como comportamental. A fase folicular ou estro é altamente variável entre ciclos e entre éguas, e dura entre 5 e 9 dias e comportamentalmente manifesta-se a receptividade ao macho. A intensidade do estro geralmente aumenta próximo à ovulação, quando o folículo dominante tem diâmetro máximo, o útero encontra-se heterogêneo e a concentração máxima de estradiol (um a três dias antes da ovulação) ocorre, na ausência da progesterona (MCCUE; SCOGGIN; LINDHOLM, 2011). 0 comportamento de estro pode se prolongar até um a dois dias após a ovulação (BERGFELT, 2009).

0 diestro (fase luteal), que significa um período de repouso entre dois períodos de estro (LOFSTEDT, 2011), é menos variável em sua duração, tendo em média de 14 a 16 dias (BERGFELT, 2009), sendo extremamente curto em relação às outras espécies (LOFSTEDT, 2011).

Como já foi mencionado no início, o caráter poliéstrico estacional de um grande número de animais determina uma mudança do ciclo estral e do perfil hormonal ao longo do ano. Nos animais que são verdadeiramente poliéstricos estacionais, quatro fases distintas são detectadas, com características hormonais e ovarianas específicas (SHARP, 2011). Elas são a fase ovulatória, correspondente à estação ovulatória, a transição de outono, o anestro e a fase de transição de primavera (AURICH, 2011).

A fase conhecida como anestro se caracteriza por ovários pequenos e inativos (THOMPSON, 2011), apesar de algumas éguas continuarem a mostrar sinais de estro durante este período (GINTHER, 1992; KING, 2011). Os folículos são menores do que $20 \mathrm{~mm}$, as concentrações de estradiol são basais, não existe corpo lúteo e por isso as concentrações de progesterona não excedem 1ng/mL (KING, 2011). Caracteristicamente o conteúdo hipotalâmico de GnRH no inverno é menor do que durante o verão (HART et al., 1984). O FSH permanece sendo encontrado na circulação sistêmica (reduzido cerca de 50\%), sendo que os folículos atingem somente cerca de 20 a $25 \mathrm{~mm}$, principalmente pela falta de hormônio luteinizante (LH) (ALEXANDER; IRVINE, 1986). Esta diferença nos dois hormônios acontece, pois existe uma produção e liberação constitutiva de FSH (liberado das vesículas secretórias assim que é sintetizado), independente de GnRH do hipotálamo (MORRESEY, 2011). 
Por outro lado, o LH necessita de níveis normais de GnRH para normal síntese e liberação (GARZA et al., 1986). Existe inclusive uma alteração celular na hipófise, sendo a densidade de gonadotrofos na pars tuberalis 4 a 5 vezes menor durante o anestro, enquanto que a pars distalis não sofre alteração. Essa sazonalidade celular na pars tuberalis é considerada responsável pela liberação diferencial entre LH e FSH durante o ciclo reprodutivo da égua (TORTONESE et al., 2001).

Os animais no período de transição para o anestro e para a estação ovulatória apresentam períodos de cios irregulares com duração de semanas a meses, sendo variáveis (GINTHER, 1992). Entretanto estas duas fases diferem marcadamente no ambiente hormonal e fatores que disparam seu início (KING, 2011).

A transição de outono erroneamente considerada o oposto da transição de primavera, envolve uma série de características que a tornam peculiar, sendo mais longa do que a transição de primavera. Aparentemente a primeira alteração para início desta fase ocorre no ovário, enquanto na transição de primavera ela ocorre no eixo hipotálamo-hipófise-gonadal. Ainda mais, a última ovulação da estação não pode ser considerada como referência para início do anestro como frequentemente ocorre, uma vez que a égua pode não estar ovulando e não se encontrar em anestro (KING, 2011).

Como características inerentes a esta fase podem ser citadas alterações na função luteal como seu prolongamento ou encurtamento e na fisiologia folicular com crescimento folicular anovulatório, folículos hemorrágicos e estro silencioso (WEEDMAN et al. 1993). A explicação endocrinológica destes eventos será a seguir pormenorizada e evidencia-se uma variação em sua sequência de acordo com o indivíduo. Iniciando no corpo lúteo, podem ser notadas falhas parciais ou totais tanto no suporte luteotrófico como na luteólise.

De acordo com King et al. (2010), eles puderam confirmar que a função luteal é comprometida durante o outono, sendo as concentrações de progesterona menores. Também puderam demonstrar que a atividade prolongada do corpo lúteo ocorre devido a uma falha na liberação de $\mathrm{PGF}_{2 \alpha}$ no momento da esperada luteólise. As concentrações de progesterona dos ciclos a partir do solstício de verão gradualmente vão declinando (KING et al., 1988), apesar do corpo lúteo (CL) não sofrer alteração de tamanho e de aspecto ultrassonográfico (KING et al., 1993). Por ter papel essencial para que ocorra a luteólise normal, a diminuição da progesterona pode alterar a ocorrência normal dela. 
Por outro lado, uma redução da fase luteal também pode ocorrer, e hipotetiza-se que a redução de suporte luteotrófico possa ser causador deste acontecimento (KING, 2011). A foliculogênese também apresenta particularidades durante este período do ano, sendo que a capacidade esteroidogênica dos folículos encontra-se diminuída e a incidência de folículos hemorrágicos anovulatórios é maior (23\% no outono vs 5 a $8 \%$ na primavera) (WEEDMAN et al., 1993; GASTAL et al., 1998). Foram descritas três diferentes possiblidades antes da entrada no anestro em éguas, sendo elas: a falha de ovulação de um folículo dominante durante a fase folicular (42 a 56\%), podendo se repetir várias vezes; após a lise normal de um CL e não retomada de crescimento folicular (25\%) e após a ocorrência de uma fase luteal prolongada, lise deste CL e posterior inatividade ovariana (20 a 33\%) (KING et al., 1993).

A secreção de LH é menor, causando um menor aumento nos seus níveis e no momento inadequado do ciclo, resultando em não ovulação (IRVINE et al., 2000). Níveis variáveis de atividade folicular ocorrem antes da entrada no anestro profundo, durante o qual o crescimento folicular é mínimo e os folículos medem em média $15 \mathrm{~mm}$, não excedendo $16 \mathrm{~mm}$, portanto não ocorrem folículos dominantes. Os níveis de LH baixos contribuem para a redução no crescimento folicular, apesar de os níveis de FSH continuarem e ondas foliculares serem detectadas (DONADEU; WATSON, 2007). A prolactina também exerce um papel nesta fase, sendo que é a primeira a sofrer um decréscimo durante o outono (KING, 2011).

De forma esquemática, baseando-se em resultados de vários trabalhos, a transição de outono pode ser dividida em quatro fases distintas. Na primeira, os ciclos estrais são aparentemente normais, sendo encontrada uma diminuição nas concentrações de prolactina e na função luteal traduzida em reduzida produção de progesterona e capacidade luteolítica. A segunda é caracterizada por ciclos aberrantes, mas ainda ovulatórios durante o final do outono com diminuição do crescimento folicular e esteroidogênese e redução no LH. Frequentemente acontecem cios silenciosos, fase luteal abreviada e fase folicular prolongada. Na terceira fase destaca-se o período anovulatório por queda de LH, impossibilitando a ovulação, com crescimento folicular por 30 ou mais dias. Finalmente atinge-se a quarta fase (que não ocorre em alguns animais) que é o anestro (NEQUIN et al., 2000).

A transição de primavera varia entre 30 a 90 dias de duração, sendo a etapa inicial para a volta à capacidade reprodutiva (SHARP, 2011), caracterizando-se por 
comportamento irregular de estro e volta de secreção das gonadotropinas e esteroides ovarianos (WATSON et al., 2002). Ela é iniciada quando o desvio folicular reinicia, havendo um folículo dominante entre 20 e $30 \mathrm{~mm}$, com um maior número de folículos maiores do que $15 \mathrm{~mm}$. Geralmente 1 a 3 ondas que não culminam em ovulação ocorrem antes que a ovulação aconteça (WATSON et al., 2002; DONADEU; WATSON, 2007). Estas ondas em geral distam cerca de 12 dias entre elas, sendo considerado o momento que um folículo $>30 \mathrm{~mm}$ é detectado até o próximo (WATSON et al., 2002). Os folículos não ovulatórios possuem menor expressão de receptores de FSH durante o anestro comparado com éguas ovulatórias, não sendo a secreção de FSH a responsável pela volta à ciclicidade (SHARP, 2011).

Alterações ao nível ovariano como expressão de receptores de dopamina tipo 2 (D2) na córtex (KING; ROSER; JONES, 2008) e expressão de membros do sistema dos fatores de crescimento tipo insulina(IGF) nos folículos podem ter importante papel. Assim como hormônios prolactina e hormônio do crescimento também devem estar envolvidos (DONADEU; WATSON, 2007). Além disso, a capacidade de produção de estrógeno pelo folículo é diminuída (SHARP; DAVIS, 1993), com menor quantidade das enzimas 17- $\alpha$ esteroide hidroxilase e enzima de clivagem da cadeia lateral; taxa de crescimento folicular menor (2mm/dia); folículos menos vascularizados (TUCKER; CLEAVER; SHARP, 1993). Após o desvio folicular, os níveis aumentados de LH são necessários para o crescimento do maior folículo, entretanto neste período ele ainda está reduzido, não provocando ovulação. Portanto, um aumento da onda de LH é um evento chave para levar à primeira ovulação (AURICH, 2011). Estas características da fase de transição descritas são causadoras de ineficiência reprodutiva e grande frustração (SHARP, 2011).

Por fim, a estação reprodutiva propriamente dita, que é o período de ciclos estrais seguidos de forma regular será descrita. Seu início é marcado pela primeira ovulação do ano e a partir deste ponto do texto serão abordados os aspectos foliculares e endócrinos que ocorrem durante esta fase.

Uma onda folicular é um grupo de folículos que são detectados em intervalo de um a dois dias entre eles (GASTAL et al., 2000) e que aumentam de diâmetro de forma semelhante até a seleção folicular ou regressão. Uma ou duas ondas foliculares se desenvolvem durante o ciclo estral, sendo que a maioria das éguas possui uma onda folicular maior (GINTHER, 1990). 
Ondas foliculares são classificadas como maiores, nas quais o folículo atinge diâmetro maior ou igual a 28 - 30mm, sendo chamado de folículo dominante. Elas incluem ondas primárias e secundárias. As ondas primárias se caracterizam por sua emergência ocorrer durante o final do diestro e nela está o folículo dominante que se tornará pré-ovulatório (MCCUE, SCOGGIN, LINDHOLM, 2011). A onda secundária emerge antes da última ovulação do período interovulatório anterior e seu folículo dominante pode não ovular, regredir ou ovular, independente dos altos níveis de progesterona circulantes (GINTHER, 1993).

O desenvolvimento de uma onda folicular ovulatória durante o diestro é uma particularidade da égua, sendo sua ocorrência variável com a raça, sendo que Pôneis geralmente possuem apenas uma onda folicular maior e PSI e cavalos de sangue quente apresentam duas ondas foliculares (GINTHER, 2000). A incidência de ovulações durante o diestro em PSI e Cavalo de sela é de 18-21\% e praticamente 0\% em Quarto de Milha, Pôneis (GINTHER, 1992) e Bretões (GINTHER et al., 2004). Além disso, os diâmetros do folículo dominante são menores (37 e 46mm) nas ondas secundárias e o útero permanece com características de diestro (GINTHER, 1993). As ondas menores são aquelas nas quais os folículos não passam dos 30mm e não ocorre seleção folicular. Em ambos os tipos ocorre a fase de crescimento comum, com um conjunto de folículos antrais no início da onda (GINTHER; BERGFELT, 1992; GINTHER, 1993; GINTHER et al., 2004; BERGFELT, 2009).

Um folículo que entra na fase de crescimento e diferenciação está comprometido irreversivelmente, e seu destino será a ovulação ou a atresia. A grande maioria, 99\% deles, irá sofrer atresia (BEG; BERGFELT, 2011). 0 folículo que se tornará pré ovulatório passa por diversas alterações de desenvolvimento sequenciais uma vez que ele deixou o pool de folículos primordiais. O futuro folículo dominante, em geral já se apresenta com um dia a mais de crescimento ou 3mm maior (GASTAL et al., 1997, 2004).

As características das ondas foliculares maiores serão abaixo descritas. 0 processo de crescimento dos folículos antrais é dividido da seguinte forma: a emergência e fase de crescimento comum se caracterizam pela emergência de vários folículos, entre 7 e 11 que crescem juntos como um grupo. Em seguida ocorre a seleção e dominância e por fim, o folículo dominante atinge a fase pré ovulatória, com o diâmetro máximo e sofre alterações morfológicas e fisiológicas para que ocorra a ovulação (BEG; BERGFELT, 2011). 
A emergência de uma onda folicular é temporalmente associada com um aumento de FSH durante o ciclo estral e 5 a 10 folículos em torno de 4-6mm crescem com 2 a 3 dias de intervalo entre si (BERGFELT, 2009), antecedendo em cerca de 6 dias o momento do desvio (GINTHER, 2000). Quando o maior folículo atinge um diâmetro de 13mm, o FSH atinge um platô e começa a diminuir (GASTAL et al., 1997).

Em seguida, inicia-se a fase de crescimento comum, durante a qual todos os folículos crescem de $2-4 \mathrm{~mm}$ por dia até que o maior folículo atinja $20-25 \mathrm{~mm}$, tendo duração de 6 a 7 dias (GINTHER et al., 2001).

Em ondas menores, neste momento todos os folículos começam a regredir, por outro lado em ondas maiores, o maior folículo escapa da regressão enquanto o restante gradualmente regride (BERGFELT, 2009; BEG; BERGFELT, 2011; GINTHER, 2012). 0 desvio folicular é considerado o momento de dissociação em diâmetro entre os folículos ao final da fase de crescimento comum, quando um ou dois folículos continuam a crescer e os outros encerram o crescimento ou regridem (GINTHER, 2000; GINTHER et al., 2003; GINTHER, 2012). Imagina-se que este seja um mecanismo para impedir que múltiplos folículos se tornem codominantes em uma espécie monovular (GINTHER et al., 2001).

O desvio acontece de forma abrupta quando o diâmetro do maior folículo atinge 22 a 25mm, e o segundo folículo atinge cerca de 19mm (GINTHER, 1992; GINTHER et al., 2004). Neste momento, uma série de mecanismos de desvio é ativada no folículo dominante, sendo considerada esta uma fase decisiva. Estes mecanismos também auxiliarão na inibição do crescimento dos folículos subordinados (BEG; GINTHER, 2006). Ginther et al. (2004b) mostraram que as concentrações de estradiol, IGF-1, inibina A e ativina A aumentam de forma diferente no futuro folículo dominante e nos futuros folículos subordinados antes mesmo do desvio, podendo ser responsáveis por aumentar a responsividade ao FSH e LH do futuro folículo dominante.

A fase de dominância é o período entre o início do desvio até o início da fase préovulatória, que dura em torno de 8 dias. Pode-se identificar a dominância morfologicamente utilizando a ultrassonografia modo Bidimensional (B), notadas pelas diferenças dos diâmetros foliculares dos dois maiores folículos. Além disso, a avaliação da presença de receptores para LH nas células da granulosa e aumento de hormônios reprodutivos e fatores de crescimento no fluido folicular também fornecem informações fisiológicas com relação à dominância (GINTHER et al., 2003). 
Desta forma, o folículo dominante é detentor de um maior número de receptores de LH tornando-o mais responsivo aos seus efeitos estimulatórios. A concentração alta de IGF-1 no fluido folicular promove maior mitogênese e crescimento do folículo dominante além de outras mudanças no sistema IGF (IGF1, IGFBP e IGFBP protease) anteriores ao desvio (BEG; GINTHER, 2006). 0 aumento dos níveis de estradiol e inibina produzidos pelo folículo dominante provoca um duplo feedback negativo que atua no eixo hipotálamo-hipófise-gonadal diminuindo as concentrações de FSH para níveis basais (DONADEU; GINTHER, 2001; BERGFELT, 2009; GINTHER, 2012), prejudicando o crescimento dos folículos subordinados (BEG; BERGFELT, 2011).

O futuro folículo dominante tem um aumento na produção de estradiol um dia antes do desvio (GASTAL et al., 2000). Uma relação inversa nos níveis em ascensão de inibina e decréscimo de FSH suportam claramente o papel da inibina no desvio (BERGFELT et al., 1991). Já os níveis de LH provavelmente não estão associados ao desvio, mas são importantes no prosseguimento do crescimento folicular após o acontecimento deste evento (GINTHER, 2000).

Os folículos subordinados por sua vez não apresentam quantidade suficiente de receptores de LH nas células da granulosa e fatores intrafoliculares regulatórios e por isso não são capazes de manter o crescimento com os baixos níveis de FSH, sofrendo regressão (BERGFELT; ADAMS, 2007; BERGFELT, 2009). Uma diferença entre o futuro folículo dominante e os folículos subordinados com relação aos sinais de fluxo sanguíneo e velocidades à ultrassonografia Doppler foi notada, sendo que futuros folículos dominantes apresentavam mais sinais de fluxo sanguíneo e maiores velocidades do que os subordinados antes mesmo do início do desvio (ACOSTA et al., 2004). Evidencia-se que a formação de uma rede vascular adequada é um fator limitante na seleção e maturação do futuro folículo dominante (REYNOLDS et al., 2000; STOUFFER et al., 2001) e mostra a importância de um suprimento sanguíneo para a manutenção folicular (REYNOLDS et al., 2000). Essa rede irá fornecer oxigênio, nutrientes e substratos assim como gonadotrofinas e auxiliará na liberação dos hormônios foliculares para a circulação (WATSON; AL-ZI'ABI, 2002).

Segundo Ginther et al. (2008), a taxa de crescimento folicular a partir do desvio é de cerca de $3 \mathrm{~mm}$ por dia até que o folículo atinja $35 \mathrm{~mm}$, cerca de 4 dias antes de ovular. 0 crescimento continua até 2 dias antes da ovulação quando a estabilização do crescimento folicular com diâmetro em torno de 40mm acontece (GINTHER et al., 2008). 
A manutenção da dominância do folículo dependerá de níveis intermediários de LH. As concentrações de estradiol neste momento vão aumentando em paralelo com o aumento do folículo dominante e atingem concentrações máximas 1 a 2 dias antes da ovulação. Além de suprimir o FSH, o estradiol na ausência de progesterona parece estimular as concentrações de LH (GINTHER, 1992; MCKINNON et al., 2011). Os altos níveis de LH no final do estro não só garantem o crescimento contínuo do folículo dominante como sinalizam e preparam o folículo e seu conteúdo para a ovulação que está se aproximando (BERGFELT; ADAMS, 2007). Estas altas concentrações de estradiol produzem um feedback positivo no eixo hipotálamo-hipofisário-gonadal, culminando na concentração máxima de LH pós ovulação. Um pequeno aumento do FSH antes da ovulação acontece em decorrência da diminuição dos níveis de estradiol apesar dos altos níveis de inibina (BERGFELT, 2009).

A fase do desenvolvimento pré ovulatório folicular e ovulação são diferentes na espécie equina (AURICH, 2011). O tamanho do folículo pré ovulatório é muito maior, podendo chegar a $55 \mathrm{~mm}$ ou mais, e repetindo-se em ciclos consecutivos nos indivíduos (CUERVO-ARANGO; NEWCOMBE, 2008). Entretanto o diâmetro do folículo pré ovulatório varia de acordo com a estação, raça, tipo de égua e número de folículos pré ovulatórios (BERGFELT, 2009). Neste período o folículo adquire a capacidade de responder a um estímulo ovulatório, seja ele endógeno ou exógeno, encontrando-se com diâmetro acima de $30 \mathrm{~mm}$, pois antes deste tamanho existe uma baixa probabilidade de ovulação espontânea (GINTHER, 1992) ou a resposta a um agente indutor de ovulação (BERGFELT et al., 2007).

O LH aumenta no momento periovulatório acompanhado de um leve aumento de FSH que decresce para seu limite inferior em seguida (BERGFELT et al., 1991). A ovulação não é iniciada por um pico de LH e sim por um aumento progressivo durante o estro, que atinge seu nível máximo 1 dia após a ovulação (STABENFELDT et al., 1972; GINTHER et al., 2006; GASTAL, 2011), diferindo das outras espécies de animais domésticos (GINTHER et al., 2010). Em seguida gradualmente os valores retornam a níveis baixos, permanecendo desta forma entre os dias 6 a 14 pós ovulação, quando novamente inicia um novo aumento que novamente culminará com o valor máximo um dia após a próxima ovulação (GINTHER, 1992; ALEXANDER; IRVINE, 2011). 


\subsection{ALTERAÇÕES DO ÚTERO E CÉRVIX AO LONGO DO CICLO ESTRAL}

As alterações do endométrio em resposta ao ambiente hormonal circulante são mediadas pela interação dos hormônios estrógeno e progesterona com seus respectivos receptores. Eles se localizam no epitélio luminal, epitélio glandular e estroma e sua expressão é influenciada pelos mesmos hormônios que neles se ligam. A expressão máxima de ambos ocorre no estro, com altas concentrações de estrógeno e diminui por influência da progesterona no diestro, com níveis mínimos no meio do diestro (HARTT et al., 2005).

A aparência ultrassonográfica do útero é influenciada dramaticamente pela fase do ciclo estral e é dependente dos níveis de esteroides ovarianos predominantes (GINTHER, 1993; PELEHACH et al., 2002). Entretanto, sabe-se que os efeitos da progesterona nas características morfológicas do útero são predominantes sobre os efeitos do estrógeno (DAELS; HUGHES, 1993). Durante o estro, as altas concentrações de estrógeno e baixas de progesterona fazem com que a parede uterina apresente edema, a cérvix fica relaxada e o útero e vagina achatam-se, com tônus uterino flácido, além de aumentar as secreções uterinas (MCCUE; SCOGGIN; LINDHOLM, 2011). Ao ultrassom as dobras endometriais são visualizadas, com áreas edematosas não ecogênicas e áreas ecogênicas de tecido denso, pois existe um aumento de fluido intersticial no tecido endometrial (GINTHER; PIERSON, 1984; HAYES; GINTHER, 1986; GRIFFIN; GINTHER, 1991; PYCOCK et al., 1995).

Durante o diestro, quando os níveis de progesterona aumentam, as dobras endometriais individualizadas não são discernidas (GINTHER, 1984; GINTHER; PIERSON, 1984; GINTHER, 1986; HAYES; GINTHER, 1986; GRIFFIN; GINTHER, 1991; PYCOCK et al., 1995) pois o edema intersticial se dissipa, e a ecotextura torna-se homogênea (MCCUE; SCOGGIN; LINDHOLM, 2011). O lúmen do corpo do útero geralmente é detectado como uma linha branca formada por reflexões especulares sobre as superfícies luminais intimamente sobrepostas. Por causa da prolongada duração dos picos de atividade mioelétrica, o total de atividade elétrica é maior durante o diestro do que o estro (TROEDSSON et al., 1993), explicando o tônus aumentado e a tubularidade que são características do útero equino durante o diestro à palpação retal (GINTHER; PIERSON, 1984; HAYES; GINTHER, 1986; GRIFFIN; GINTHER, 1991; BONAFOS et al., 
1994; MCCUE; SCOGGIN; LINDHOLM, 2011). Nesta fase a cérvix encontra-se fechada (GINTHER, 1992).

Estudos com suplementação com progesterona em éguas não cobertas durante a estação anovulatória e ovulatória mostram que a progesterona é responsável por pelo menos parte do tônus do diestro. Ocorre um aumento gradual de tônus uterino em éguas não cobertas do dia 0 (dia da ovulação) ao dia 6 e subsequente queda de tônus entre os dias 6 e 10. Esses achados demonstram que o tônus uterino durante o ciclo estral segue um padrão bimodal com pontos mais baixos no dia 0 e 10 e picos nos dias 6 e 13 . Este aumento de tônus com pico no dia 6 pós ovulação pode estar relacionado com um aumento de estrógenos neste momento (BONAFOS et al., 1994). Os escores uterinos não foram diferentes nas éguas tanto no período anovulatório, na ausência de progesterona, quanto no meio do período de diestro. Com isso, foi sugerido que baixas concentrações de estrógeno têm maior importância do que altos índices de progesterona no desenvolvimento de endométrio característico de diestro (HAYES et al., 1985). Hayes e Ginther (1986) afirmaram que deve existir estrógeno associado à progesterona para que o tônus uterino seja máximo (similar ao encontrado no $16^{\circ}$ e o $25^{\circ}$ dia de gestação).

A progesterona exógena tem sido utilizada para melhorar o tônus uterino de éguas com baixo tônus durante o início da gestação (SQUIRES, 1993), pois a administração de progesterona em éguas ovariectomizadas ou intactas causou espessamento uterino ou um tônus característico de diestro. Porém este aumento não se equiparou ao que ocorre durante a gestação. Durante o diestro, quando o edema desaparece, a densidade tecidual aumenta, e os cornos ficam mais tubulares com maior espessura, sendo de intensidade intermediária em relação ao tônus e espessura encontrados no estro e no início da prenhez (GINTHER, 1993).

Essa mudança importante no tônus uterino a partir do dia 14 a 16 do ciclo estral que ocorre em éguas gestantes, acima daquele encontrado durante o diestro, provavelmente ocorre pela secreção contínua de progesterona pelo corpo lúteo aliado ao estrógeno de origem embrionária e/ou materna (HAYES; GINTHER, 1986). A progesterona tem caráter essencial nas interações dinâmicas físicas entre concepto e endométrio, incluindo mobilidade, fixação, orientação e sobrevivência do embrião (KASTELIC; ADAMS; GINTHER, 1987). 


\subsection{OVULAÇÃO}

A ovulação ocorre em um lugar específico do ovário, a fossa ovulatória. Isto se deve à conformação particular do ovário da égua no qual a medular se localiza no exterior e a cortical no interior (GINTHER, 1992).

A maioria das éguas ovula quando o folículo pré ovulatório mede cerca de $40 \mathrm{~mm}$ (GINTHER et al., 2007b), entretanto pode variar de acordo com o período do ano, raça e indivíduo e a presença de um ou dois folículos preovulatórios no ovário (BERGFELT, 2009; GASTAL, 2011).

O momento da ovulação geralmente é usado como referência de tempo para outros eventos reprodutivos ou tratamentos pós ovulação, e é denominado d0.

A ovulação espontânea ocorre como resultado da resposta do folículo dominante a um aumento nas concentrações circulantes de LH (BERGFELDT; ADAMS, 2007), que dispara uma cascata de eventos (HAFEZ; HAFEZ, 2000), culminando na liberação do oócito do interior do folículo. Uma série de mudanças bioquímicas, fisiológicas e morfológicas no tecido folicular serão fundamentais para que este complexo evento ocorra (PIERSON, 1993). Ela pode ser induzida artificialmente ou adiantada durante a fase de transição e na estação reprodutiva por preparações tipo LH (hCG) ou preparações que causem liberação do LH endógeno (análogos do GnRH) (BERGFELDT; ADAMS, 2007).

A onda de LH que resultará na ovulação é iniciada de forma lenta ainda antes do desvio folicular. Assim que ocorre o pico esteroidogênico, dois dias antes da ocorrência da ovulação, um aumento mais rápido do LH começa, atingindo seu valor máximo um dia após a ovulação (GINTHER, 2012). Após o aumento do LH, este se liga ao seu receptor e ativa a adenil ciclase e estimula a via da proteína quinase $\mathrm{A}$, induzindo nas células da granulosa a expressão de genes codificando receptor de progesterona, cicloxigenase 2 (COX-2) (WONG; RICHARDS, 1991; SIROIS et al., 1992; RICHARDS, 1994; BOERBOOM; SIROIS, 2004; STOUT, 2011), prostaglandina endoperóxido sintase 2, entre outros (RICHARDS et al., 1998; ROBKER et al., 2000).

O processo ovulatório consiste na destruição de tecido folicular (HAFEZ; HAFEZ, 2000), sendo uma reação inflamatória (ESPEY; LIPNER, 1994) que envolve hiperemia, congestão, aumento da permeabilidade vascular e edema (KERBAN; DORE; SIROIS, 
1999). Estudos realizados avaliando os genes responsáveis por este evento têm evidenciando a sua complexidade, envolvendo uma gama enorme de genes da cascata de inflamação. Existem 4 grupos entre eles, sendo o primeiro responsável pela resposta aguda da reação inflamatória; o segundo participante de eventos pró inflamatórios que levam à degradação proteolítica do folículo; o terceiro tem principal papel na atividade antiinflamatória para promover a cicatrização e reparação no ovário e o quarto grupo são genes protetores de estresse oxidativo ocasionado pela ovulação (ESPEY; BELLINGER; HEALY, 2004).

Todas as camadas que separam o oócito do meio externo devem ser rompidas: epitélio da superfície do ovário, a teca externa, a membrana basal entre a rede capilar e a granulosa. Ao mesmo tempo um aumento do aporte sanguíneo ocorre em todo o folículo, exceto no ponto onde será a ruptura (ESPEY; LIPNER, 1994; HAFEZ; HAFEZ, 2000).

A ruptura folicular, com liberação do fluido folicular durante a ovulação é um evento dinâmico e já bem descrito em éguas (GINTHER, 1992; GINTHER et al., 2004).

Durante a ovulação, mudanças na função de células do folículo (células da teca e granulosa) e estroma (células endoteliais e fibroblastos) e epitélio superficial ovariano devem ocorrer (ESPEY; LIPNER, 1994), além da invasão e aliciamento de células inflamatórias (neutrófilos e macrófagos) produtoras de citocinas. 0 papel delas é a regulação do processo, agindo tanto nas próprias células imunes como nas células ovarianas (NORMAN; BRANNSTROM, 1994).

0 processo de ovulação em equinos envolve um padrão especifico e único de regulação gênica nas células da teca e granulosa mural, sendo que ocorre diferença na expressão de vários fatores como prostaglandinas e enzimas metabolizadoras de prostaglandina (SAYASITH et al., 2007).

A COX-2, conhecida também como prostaglandina G/H sintase-2 (PGH-2) é responsável pela produção tanto de $\mathrm{PGF}_{2}$ e $\mathrm{PGE}_{2}$ no folículo entre 10 e 12 horas antes da ovulação (SIROIS; DORE, 1997; CUERVO-ARANGO; DOMINGO-ORTIZ, 2011). A síntese dela é estimulada nas células da granulosa pelo LH e provoca a ruptura de lisossomos localizados nas células do epitélio no ápice do folículo, e também leva a contrações de fibras musculares no ovário. Com isso, a pressão do folículo aumenta associado com a fina parede folicular, facilitando sua ruptura. A $\mathrm{PGE}_{2}$ causa remodelamento tecidual, preparando o folículo para se tornar um CL. Ela ativa o plasminogênio que é convertido para plasmina pelo fator ativador de plasminogênio e a plasmina é a enzima responsável 
por este remodelamento tecidual e pela dissolução do coágulo no corpo hemorrágico. Pode ser notada uma separação das células do cumulus e posterior aproximação ao redor do oócito devido ao estímulo de síntese de colagenase pelo aumento da progesterona, o que provoca a formação da corona radiata (HAFEZ; HAFEZ, 2000).

Três etapas importantes devem ocorrer no folículo pré ovulatório durante a ovulação. A primeira consiste na maturação do citoplasma e núcleo do oócito, em seguida uma diminuição da adesividade das células da granulosa e por fim adelgaçamento e ruptura da parede folicular externa (HAFEZ; HAFEZ, 2000). 0 resultado é a evacuação do fluido folicular (GINTHER, 1992; GINTHER et al., 2004), células da granulosa e complexo cúmulus oócito (BERGFELT, 2009), levando a uma diminuição no tamanho do antro e acúmulo de fluido folicular na bursa ovariana e área circundante (BERGFELDT; ADAMS, 2007).

Existem relatados na literatura dois tipos de evacuação folicular, a forma abrupta e a gradual (GINTHER, 1992; GINTHER, 1995; GASTAL, 2011; GINTHER, 2012), sendo a ocorrência de cada uma delas de 50\%. Durante a abrupta, 15\% do fluido folicular permanece no folículo, e sua duração é entre 5 a 90 segundos. A liberação do fluido folicular lenta é gradual e dura entre 6 e 7 minutos, e 4 a 17\% do volume inicial do folículo permanece. 0 desaparecimento completo do fluido antral e espaço extraovariano é bem mais lento podendo demorar entre 30 minutos até 5 a 20 horas (TOWNSON; PIERSON; GINTHER, 1989; GINTHER, 1992; GINTHER, 1995; GASTAL, 2011; GINTHER, 2012).

Com o advento da ovulação, os níveis de progesterona circulantes começam a aumentar gradualmente acompanhando o desenvolvimento do corpo lúteo. Os níveis de LH irão diminuir provavelmente como consequência do feedback negativo da progesterona na responsividade da hipófise ao GnRH (GREAVES et al., 2001), maior regulador de secreção de LH em éguas (ALEXANDER; IRVINE, 1996). A progesterona circulante será responsável por cessar o comportamento de estro e iniciará o comportamento de diestro, deixando a égua de ser receptiva ao garanhão (BERGFELT, 2009). 


\subsection{CORPO LÚTEO}

O corpo lúteo é a estrutura responsável pela síntese e secreção da progesterona, fundamental para estabelecimento e manutenção da gestação em éguas (BOWENSHAUVER; GIBORI, 2004). As características desta glândula ao longo do ciclo estral no que diz respeito a sua morfologia, histologia e função serão discutidas nesta parte da revisão de literatura.

\subsubsection{Histórico}

0 primeiro relato da existência do corpo lúteo (CL) remete a Falloppio ${ }^{1}$ (1561 (1561 apud BOWEN-SHAUVER; GIBORI, 2004, p. 201). Entretanto foi Marcello Malpighi (1628-1694) (MALPIGHI,2 1685 apud BOWEN-SHAUVER; GIBORI, 2004, p. 201) que o nomeou como corpo lúteo, cujo significado corpo amarelo pode ser enganoso uma vez que na maioria das espécies ele tem coloração vermelha ou roxa devido à sua intensa vascularização (BOWEN-SHAUVER; GIBORI, 2004). No mesmo período, Regnier de Graaf notou a presença de corpos lúteos nos ovários de coelhos após o coito até o parto, e os chamou de corpos globulares. Ele também relacionou o número de estruturas no ovário com o número de fetos (DE GRAAF, ${ }^{3} 1672$ apud NISWENDER et al., 2000, p. 1).

Prenant em 1898 fez avaliações histológicas do CL e falou que não poderia haver dúvidas de que o CL agia como uma glândula de secreção interna, e sugeriu sua relação com a gestação. No início do século XX, Fraenkel e Magnus retiraram os corpos lúteos ou ovários de coelhas prenhes e notaram perda da gestação (PRENANT, ${ }^{4} 1898$ apud BOWEN-SHAUVER; GIBORI, 2004, p. 201).

\footnotetext{
${ }^{1}$ FALLOPPIO, G. Observationes Anatomicae, translator L. G.Wilson. Venice, 1561.

${ }^{2}$ DE GRAAF, R. De Mulerium Organis Generationi Inservientibus Tractatus Novus. Leydon, The Netherlands, Hackiana, 1672.

${ }^{3}$ MALPHIGHI, M. Praeclarissimo et eruditissimo viro d. Jacobo Sponio medicinae doctori et ludgeunense Anatomico Accuratissimo. Phil. Trans. R. Soc., (Lond.), v.14, p.630, 1685.

${ }^{4}$ PRENANT, A. La valeur morphologique du corps jaune. Son action physiologique et therapeutique possible.

Revue Generale de Sciences Pare et Appliquees, v. 9, p, 646-650, 1898.
} 
Mais tarde, quatro foram os grupos que simultaneamente caracterizaram e cristalizaram o produto do CL, um hormônio esteroide que foi chamado de progesterona por suas características pró gestacionais (NISWENDER et al., 2000).

Com isso, evidenciamos o antigo interesse da humanidade por esta estrutura intrigante e fundamental para a sobrevivência das espécies. Muitos aspectos permanecem por ser desvendados, tornando o corpo lúteo uma glândula ainda repleta de questões a serem respondidas, como veremos a seguir.

\subsubsection{Formação e Composição do CL}

A formação do CL após a ovulação é resultado de um dinâmico e complexo processo de luteinização das células do folículo, regulado por luteotrofinas (FERREIRADIAS; SKARZYNSKI, 2008; SKARZYNSKI; FERREIRA-DIAS; OKUDA, 2008), essencial para que possa ser sintetizada a progesterona (MURPHY, 2004). Esta glândula transitória (FERREIRA-DIAS et al., 2011), de natureza efêmera, torna-se única no ovário de mamíferos (MIYAMOTO et al., 2009), e é essencial para que a gestação possa se estabelecer (BOWEN-SHAUVER; GIBORI, 2004).

Logo após a ovulação, ocorre uma desestruturação e reorganização da parede folicular, ruptura da membrana basal ocorrendo uma invasão de fibroblastos e vasos sanguíneos da teca interna para o corpo lúteo em desenvolvimento ao mesmo tempo que ocorre a hipertrofia das células da granulosa (BERGFELT, 2009; GASTAL, 2011).

A luteinização envolve a morfogênese estrutural e funcional das células da granulosa produtoras de estrógeno para células luteais produtoras de progesterona (MURPHY, 2004; BERGFELT; ADAMS, 2007; BERGFELT, 2009). 0 grau de migração e mistura das células derivadas do folículo na formação do CL difere entre as espécies. 0 tecido folicular sofre um extensivo rearranjo, envolvendo a diferenciação e crescimento das células luteais grandes e pequenas (ROBERTO DA COSTA et al., 2005) e proliferação de células não luteais (células do sistema imune e fibroblastos), além de grande angiogênese (TAMANINI; DE AMBROGI, 2004; ROBERTO DA COSTA et al., 2005; FERREIRA-DIAS et al., 2006), sendo que todos os tipos celulares encontram-se em grande proximidade (DHARMARAJAN; BRUCE; MEYER, 1985; FARIN et al., 1986). 
No início do desenvolvimento do CL um aspecto importante é a taxa de crescimento tecidual e proliferação celular (FARIN et al., 1986; ROBERTO DA COSTA et al., 2005; FERREIRA-DIAS et al., 2006), que resulta em taxa mitótica comparável aos tumores de maior crescimento (JABLONKA-SHARIFF et al., 1993) e à placentação (FRASER; LUNN, 2001).

Mudanças na expressão de enzimas esteroidogênicas e proteína de regulação aguda esteroidogênica com o objetivo de produzir grandes quantidades de progesterona acontecem durante este processo (MURPHY, 2004). Durante a luteinização, as gap junctions presentes entre as células da granulosa e da teca antes da ovulação voltam a se reestabelecer, tornando o parênquima luteal altamente conectado, sugerindo um alto grau de comunicação intercelular (REYNOLDS; REDMER, 1994). A luteinização é considerada terminada entre os dias 3 a 5 após a ovulação (GINTHER, 1992).

Apesar da ideia de que o CL seja formado apenas de células luteais, ele possui uma mistura heterogênea de tipos celulares, com aspecto anatômico e funções biológicas distintas (SKARZYNSKI; FERREIRA-DIAS; OKUDA, 2008).

Existem dois tipos de células esteroidogênicas, as células luteais grandes e pequenas classificadas por diferenças morfológicas (células luteais pequenas são escuras e medem cerca de $10 \mu \mathrm{m}$ e células luteais grandes são claras com cerca de $40 \mu \mathrm{m}$ ) e bioquímicas (VAN NIEKERK et al., 1975; KELLY et al., 1988; ROBERTO DA COSTA et al., 2005; SKARZYNSKI; FERREIRA-DIAS; OKUDA, 2008). Além disso, provavelmente relacionado com a maior capacidade secretória das células luteais grandes, elas possuem maior quantidade de retículo endoplasmático liso e rugoso, complexo de Golgi e grânulos secretórios em comparação com as células luteis pequenas (STOUFER, 2004). Acredita-se que as células luteais pequenas sofrem diferenciação em células luteais grandes com o progresso do CL (VAN NIEKERK et al., 1975; LEI; CHEGINI; RAO, 1991).

De acordo com Ginther (1992), as células da teca não serão precursoras das células luteais pequenas, uma vez que anterior à ocorrência da ovulação, elas iniciam um processo de degeneração e substituição por fibroblastos hipertrofiados, diferindo do encontrado em outras espécies (VAN NIEKERK et al., 1975). Entretanto Watson (2000) encontraram células da teca entre as células luteais grandes no CL do meio do diestro, gerando ainda um debate com relação ao papel das células da teca na formação do corpo lúteo. 
Ao longo do tempo de desenvolvimento do corpo lúteo, as quantidades de células produtoras de progesterona vão sofrendo alterações. Uma variação na proporção entre células luteais grandes e pequenas foi encontrada ao longo do ciclo estral, sendo que ela diminuiu de $46 \%$ no $\mathrm{d} 4$ a $\mathrm{d} 5$, para $38,5 \%$ no $\mathrm{d} 8$ a $\mathrm{d} 9$ para $24,3 \%$ no d12 a d 13 (WATSON; SERTICH, 1990). De acordo com Roberto da Costa et al. (2005), não houve diferença no número de células luteais pequenas ao longo do desenvolvimento do CL contrastando com o aumento do número de células luteais grandes entre o corpo hemorrágico $(\mathrm{CH})$ e o $\mathrm{CL}$ no meio do diestro. Em seguida, os números novamente diminuem, comparáveis com o $\mathrm{CH}$.

As outras células que formam o CL são fibroblastos, pericitos, células musculares lisas, células do sistema imune (macrófagos, linfócitos) e células endoteliais do folículo pós ovulatório (NISWENDER et al., 2000).

Não existe um grande número de estudos histológicos da composição celular e formação do CL em equinos diferindo de outras espécies tais como bovinos e ovinos. Por isso, muitas das informações utilizadas são extrapoladas do conhecimento obtido nos outros modelos animais.

No início da fase luteal, as células luteais produtoras de progesterona estão em intensa mitose (AGUILAR et al., 2006). A maioria das células que estão em proliferação durante o processo de formação do novo CL são células endoteliais que se encontram em condições de hipóxia. Por isso uma intensa angiogênese regulada por fatores angiogênicos, como o fator de crescimento vascular endotelial (VEGF) produzido pelas próprias células luteais se inicia (AL-ZI'ABI et al., 2003).

A maturação do CL primário é considerada completa entre os dias 5 e 10 pós ovulação (meio do diestro). 0 corpo lúteo da égua é funcional por cerca de 14 a 15 dias durante o ciclo não fertilizado (DAEL; HUGHES, 1993), até sofrer luteólise.

\subsubsection{Tipos de Corpo Lúteo}

A morfologia do CL primário após a ovulação não é única e uniforme, sendo dois tipos descritos após a ovulação. A formação de corpo hemorrágico, que é um corpo lúteo com uma cavidade preenchida de sangue, ocorre em 50 a $70 \%$ dos ciclos de forma 
aleatória (BERGFELT, 2009). Geralmente a cavidade é detectada no d0 em 28\% dos animais e no d1 em 62\%. A parte da cavidade é maior proporcionalmente no início do diestro, e diminui gradativamente com a organização do coágulo e presença de tecido conjuntivo no meio do diestro. Eventualmente continua presente até o final do diestro (BERGFELT; ADAMS, 2011). Eles são em torno de 17\% maiores do que o outro tipo, entretanto a área de tecido luteal é semelhante (BERGFELT; ADAMS, 2007). Ele pode se tornar uma estrutura sólida com o passar do tempo, assemelhando-se a CL sem cavidade (BERGFELT; ADAMS, 2011).

O CL que não apresenta cavidade acontece em 30-50\% dos ciclos e permanece com este aspecto ao longo de sua duração (GINTHER, 1992; ARRUDA et al., 2001; BERGFELT, 2009). A morfologia do CL não parece estar associada a indivíduos e duplas ovulações parecem ter a mesma chance de serem iguais morfologicamente ou diferentes (GINTHER, 1992). Independente do aspecto morfológico da glândula lútea formada, a produção de progesterona e intervalo interovulatório são comparáveis (GINTHER, 1992; GINTHER, 1995; ARRUDA et al., 2001).

O corpo lúteo em éguas gestantes e não gestantes tem um comportamento funcional e morfológico semelhante até o dia 14 pós ovulação, quando se inicia o processo de lise do corpo lúteo nas não gestantes (SEVINGA et al., 1999; SAMPER et al., 2007).

Os dois tipos de corpo lúteo, CH e CL acima citados se referem ao aspecto morfológico das estruturas. Porém, uma classificação com relação ao momento fisiológico durante o qual o corpo lúteo se forma ou em que momento ele se encontra do seu desenvolvimento existe. Abaixo serão descritos os tipos de corpo lúteo encontrados.

O corpo lúteo primário resulta da ovulação de um folículo dominante de uma onda folicular primária no ou perto do fim do estro, quando o estrógeno predomina circulante (GINTHER, 1990; GINTHER, 1992).

O corpo lúteo secundário resulta da ovulação de um folículo dominante de uma onda secundária durante o diestro ou início da gestação sob domínio progesterônico. Tanto o corpo lúteo primário quanto o secundário que se desenvolvem com uma cavidade com fluido são denominados corpo hemorrágico (GINTHER, 1990).

Quando ocorre a luteinização de um folículo dominante anovulatório, em especial no início da gestação, ele é denominado de corpo lúteo acessório. Os corpos lúteos 
secundários e acessórios que se desenvolvem durante o diestro e início da gestação são denominados de corpos lúteos suplementares (GINTHER, 1990).

Finalmente, o tecido cicatricial resultante da regressão do corpo lúteo denominase corpo albicans e pode ser detectado no final do diestro e início do estro como uma área hiperecogênica no ovário. Esta denominação se aplica independente da origem do CL (BERGFELT, 2009).

\subsubsection{Regulação do Corpo Lúteo}

A regulação da formação, função e regressão luteal abrangem uma gama enorme de fatores, a respeito dos quais ainda muito pouco é compreendido (FERREIRA-DIAS; SKARZYNSKI, 2008), a despeito dos avanços alcançados em seu conhecimento (FERREIRA-DIAS et al., 2011). O levantamento da literatura disponível sobre este assunto mostra os fatores e mecanismos conhecidos, as dúvidas sobre seu verdadeiro papel e importância, deixando evidente o amplo campo de pesquisa para ser explorado, com o intuito de tentar esclarecer e desvendar o funcionamento do corpo lúteo em éguas.

Atualmente, um grande número de fatores têm sido relacionados com a regulação do CL equino, abrangendo a progesterona (ROBERTO DA COSTA et al., 2005), prostaglandinas, óxido nítrico, fatores de crescimento e angiogênicos (FERREIRA-DIAS et al., 2006; 2011; GALVÃO et al., 2012), e citocinas produzidas pelas células imunes no CL, como o TNF $\alpha$ e INF $\gamma$ (SKARZYNSKI; FERREIRA-DIAS; OKUDA, 2008).

Por definição, os hormônios luteotróficos são aqueles que suportam o crescimento e função do CL (NISWENDER et al., 2000) e o LH e PGE 2 são considerados os principais representantes (FERREIRA-DIAS; SKARZYNSKI, 2008). O LH liberado de forma pulsátil pela hipófise é um dos reguladores de síntese e secreção de progesterona pelo CL mais potentes em animais domésticos (NISWENDER et al., 2002). Entretanto, apesar de ter sido considerado por décadas o único hormônio responsável pela ovulação e formação, desenvolvimento, manutenção e função secretória do CL (GINTHER, 1992), sabe-se que o mecanismo de controle do CL é bem mais complexo, e pode envolver fatores produzidos tanto dentro do CL como fora do ovário. 
Atualmente mediadores e fatores autócrinos e/ou parácrinos parecem também desempenhar uma função importante. Citocinas podem ser responsáveis por desenvolvimento e manutenção luteal (REYNOLDS; REDMER, 1999; BERISHA; SCHAMS, 2005), prostaglandinas e outros metabólitos do ácido araquidônico (PGE, PGF, LT), neuropeptídeos (noradrenalina), hormônios peptídeos (ocitocina), óxido nítrico, fatores de crescimento, VEGF, FGF, EGF, GH, PRL, esteroides ( $17_{\beta}$ estradiol e progesterona) também são envolvidos nestes mecanismos luteotróficos (SKARZYNSKI; FERREIRADIAS; OKUDA, 2008).

Alguns dos trabalhos que fornecem argumentos, demonstrando a função destas substâncias na regulação luteal são citados abaixo.

Os dados de um estudo sugerem a presença de um sistema intraluteal de geração de óxido nítrico $(\mathrm{ON})$, que pode ter papel na regulação do CL. A óxido nítrico sintase endotelial (e $\mathrm{NOS}$ ) e a óxido nítrico sintase induzida (iNOS) foram detectadas no citoplasma de células luteais grandes e células endoteliais. A eNOS provavelmente tem uma função relevante na angiogênese nos estágios inicias e efeito oposto na luteólise. Já foi demonstrado também que o ON induz apoptose em CL humano (VEGA et al., 2000) e bovino (KORZEKWA et al., 2006). Em equinos a eNOS aumenta no final da fase luteal provavelmente participando na luteólise também nesta espécie (FERREIRA-DIAS et al., 2011).

De acordo com a literatura, Ferreira-Dias et al. (2011) encontraram produção in vitro de progesterona estimulada por LH maior em CL recente em comparação com CL no meio do diestro. 0 grupo propôs uma maior sensibilidade do CL no início do diestro aos baixos níveis de LH do que no CL no meio do diestro. Fisiologicamente é no meio do diestro que as concentrações de LH estarão mais baixas (GINTHER, 1992; GINTHER et al., 2005) e portanto sua função deve ser mais importante no início da fase luteal e menor com o passar do tempo.

$\mathrm{O} \mathrm{TNF}_{\alpha}$ adicionado in vitro às células luteais de corpo lúteo recente aumentou a proliferação endotelial (COSTA et al., 2006), o que pode indicar um papel deste fator de estimulante de fatores angiogênicos no início da fase luteal, além de ter um efeito positivo na produção de progesterona e PGE (GALVÃO et al., 2012). Uma diminuição na produção luteal de $\mathrm{PGF}_{2 \alpha}$ também foi detectada in vitro quando adicionado o $\mathrm{TNF}_{\alpha}$ à células de corpo lúteo recente, e um aumento da mesma foi encontrado quando as células do CL do meio do diestro ou em regressão foram tratadas. Os autores sugerem 
um papel desta citocina na modulação da produção intraluteal de $\mathrm{PGF}_{2 \alpha}$. variável de acordo com a fase do CL (GALVÃO et al., 2012). Com isso, este fator apresenta importante influência tanto na angiogênese como na produção de prostaglandinas e progesterona tempo dependente (FERREIRA-DIAS; SKARZYNSKI, 2008).

Outro fator investigado pelo mesmo grupo foi o IFN $\gamma$, que não causou nenhum efeito in vitro na produção de progesterona e prostaglandinas pelas células do corpo lúteo recente. Entretanto uma diminuição de $\mathrm{PGE}_{2}$ e progesterona foi provocada nas células do CL em regressão quando IFN $\gamma$ e $\mathrm{TNF}_{\alpha}$ foram adicionados, aliada a uma diminuição na viabilidade celular e aumento da apoptose. Provavelmente num momento mais tardio da fase luteal, estas substâncias sejam importantes na luteólise (GALVÃO et al., 2012).

PGE2, VEGF e IGF (FERREIRA-DIAS et al., 2011) parecem ter papel mais tarde durante a fase luteal. A IGF, por exemplo, apresenta efeito estimulatório da esteroidogênese e protege células contra a apoptose (WATSON et al., 2005). Em CL equino, a interação de $\mathrm{ON}$ e $\mathrm{PGE}_{2}$ pode participar dos mecanismos luteoprotetores requeridos para formação e manutenção do ciclo estral como sugerido em bovinos (KORZEKWA et al., 2007; FERREIRA-DIAS et al., 2011). VEGF também foi detectado no CL em éguas (TAMANINI; DE AMBROGI, 2004) e o estímulo luteotrófico e angiogênico no CH suporta uma neovascularização extremamente rápida coordenada com desenvolvimento não vascular durante o processo de luteinização (FERREIRA-DIAS, 2006).

A progesterona tem efeito luteotrófico (ROTCCHILD, 1981) e influencia a síntese de esteroide pelo CL (CHAPPEL et al., 1997; KOTWICA; REKAWIECKI; DURAS et al., 2004) em muitas espécies. A ação da progesterona de forma autócrina por meio do receptor de progesterona parece manter a função endócrina do $\mathrm{CL}$, pois suprime o início da apoptose (SKARZYNSKI; OKUDA, 1999). A expressão de seus receptores no CL equino aumenta concomitantemente com o aumento da progesterona circulante em células luteais grandes, enquanto não encontraram expressão em células luteais pequenas (ROBERTO DA COSTA et al., 2005; FERREIRA-DIAS; SKARZYNSKI, 2008).

Ainda não está estabelecido se a progesterona afeta a secreção da $\mathrm{PGE}_{2}$, uma vez que os resultados de experimento mostraram que as células luteais grandes e pequenas in vitro são capazes de produzir $\mathrm{PGE}_{2}$, contudo o tratamento das células com 
pregnenolona não provocou aumento na síntese de progesterona, diferindo dos achados em bovinos (FERREIRA-DIAS et al., 2006b; FERREIRA-DIAS; SKARZYNSKI, 2008).

Os mecanismos protetores contra os efeitos nocivos do estresse oxidativo também são fundamentais para a manutenção da função luteal (AL-GUBORY et al., 2012). Altos níveis de enzimas antioxidantes são encontrados, incluindo a SOD (superóxido desmutase), catalase, glutationa peroxidase, glutationa transferase e glutationa redutase, garantindo a proteção das células luteais contra as espécies reativas de oxigênio produzidas durante a esteroidogênese (CHEW et al., 1984). Esses radicais livres podem ter papel também na lise e apoptose do CL (RILEY; BEHRMAN, 1991).

Um recente estudo demonstrou curiosamente a presença de receptores para melatonina no tecido luteal equino independente da influência do fotoperíodo. Também mostraram que a melatonina inibiu a produção de progesterona estimulada pelo eCG e foscolina por um mecanismo de inibição direta na P450scc. Com isso, o papel da melatonina na esteroidogênese fica claramente evidenciado (PEDREROS; RATTO; GUERRA, 2011).

Fica evidente, com base nos resultados encontrados a respeito da regulação luteal, a complexidade do suporte trófico do CL ao longo de sua formação, desenvolvimento, função e lise em equinos, tornando fundamental a realização de novos estudos.

\subsubsection{Características Morfológicas do Corpo Lúteo}

A fossa ovulatória é o resultado de um rearranjo estrutural único do ovário equino que é estabelecido antes da puberdade (GINTHER, 1992). Diferente do que ocorre em outras espécies domésticas o CL é totalmente contido no estroma ovariano, o que torna a avaliação por palpação muito difícil e subjetiva. 0 exame ultrassonográfico por sua vez é uma forma imediata e objetiva (GINTHER, 1995), sendo a abordagem mais atual para pesquisadores, clínicos responsáveis pelo manejo reprodutivo, pois permite uma avaliação precisa, eficiente e segura do ovário e da glândula luteal, além do controle do desenvolvimento e detecção de um potencial mau funcionamento (BERGFELT; ADAMS, 2007). 
Ao longo de todo o ciclo, percebe-se a região que separa o tecido lúteo (menos ecogênico) do estroma ovariano (mais ecogênico, tecido mais denso e menos vascularizado) devido à diferença de impedância dos ecos na interface dos tecidos. Deste modo, o CL é facilmente identificado no ovário ao longo de todo o ciclo, até regredir (BERGFELT; ADAMS, 2011).

Desta forma, informações morfológicas (área, diâmetro e ecogenicidade luteal) e funcionais (fluxo sanguíneo) tornam-se extremamente úteis, pois têm alta correlação com características endócrinas (produção de progesterona) ao longo da maturação e regressão durante o ciclo estral e início da gestação (ARRUDA et al., 2001; SAMPER et al., 2007).

A ecogenicidade do CL pode ser classificada por um escore de tons de cinza no Modo B do ultrassom. Escores baixos indicam escuro, ou seja, hipoecogênico e escores altos representam tecido claro, mais ecogênico. A avaliação visual do CL é baseada em um escore de cinza de 0 (preto, anecóico) a 4 (branco, hiperecóico) (BERGFELT; ADAMS, 2011). Utilizando análises subjetivas e objetivas por mensuração de pixels da imagem, Ginther (1995) mostrou paralelismo entre os resultados, demonstrando a confiabilidade da avaliação subjetiva. Como a avaliação subjetiva é mais prática, ela pode ser utilizada como ferramenta diagnóstica no desenvolvimento do corpo lúteo (GINTHER, 1995).

Um corpo lúteo ainda no início do diestro apresenta alta ecogenicidade, devido à aposição das paredes foliculares, e o tecido durante o processo de luteinização é mais denso. Os escores de ecogenicidade aumentam após a ovulação, atingindo valores máximos entre 24 e 48h. A partir deste momento, os valores diminuem progressivamente, até chegarem a valores baixos no dia 9 pós ovulação (BERGFELT; ADAMS, 2007). Conforme a maturação do CL ocorre, as células luteais aumentam de diâmetro, apresentam núcleo vesiculado e vacúolos pequenos no citoplasma, indicando um aumento de síntese celular e secreção de progesterona. Concomitantemente com estas alterações morfológicas e funcionais típicas da luteinização, a gênese de vasos sanguíneos e linfáticos acompanha a invasão do tecido luteal pelo estroma. Nesta fase, o tecido é mais esparso, as células são maiores e secretoras e o fluxo sanguíneo e linfático para o corpo lúteo é maior. Desta forma justifica-se a menor ecogenicidade apresentada pelo CL maduro durante o meio do diestro. A regressão luteal é caracterizada por uma ecogenicidade aumentada novamente durante o final do diestro (GINTHER, 1992). 
Outra avaliação morfológica avaliada é a medida do diâmetro do corpo lúteo, realizada na maior imagem ao ultrassom encontrada e congelada. A maior medida de um lado a outro é feita e em seguida uma medida perpendicular a esta. Calcula-se a média das duas e determina-se o diâmetro médio (BERGFELT; ADAMS, 2011).

A área do CL pode ser determinada utilizando o diâmetro na formula: Área $=\pi r^{2}$ ou ainda nos novos aparelhos de ultrassom que possuem tal ferramenta. 0 volume pode ser calculado pela fórmula Volume $=4 / 3 \mathrm{r}^{3}$ (GINTHER, 1998; LOFSTEDT; IRELAND, 2000). A área do CH é calculada subtraindo-se da área total, a área da cavidade intraluteal. Apesar do diâmetro do $\mathrm{CH}$ ser maior do que o do CL homogêneo, a área de tecido luteal não é diferente entre os dois tipos (BERGFELT; ADAMS, 2007).

Durante os dias 0 e 5 pós ovulação (diestro inicial) ocorre uma maturação funcional do CL, evidenciada por um aumento progressivo das concentrações de progesterona circulantes associada com um aumento do diâmetro e área do CL. Ginther et al. (2007) detectaram um decréscimo gradual na área do CL do d4 ao d19. Entretanto o volume das células produtoras de progesterona aumenta significativamente do início da fase luteal ao meio, quando o volume máximo é atingido (VAN NIEKERK et al., 1975; AGUILAR et al., 2006).

Após o dia 9, é iniciada a regressão funcional do CL, que se caracteriza por diminuição progressiva dos níveis de progesterona, do diâmetro, área e vascularização do CL e um aumento de sua ecogenicidade. As mudanças morfológicas do CL antecedem mudanças funcionais tanto na maturação como na regressão (BERGFELT; ADAMS, 2007).

\subsubsection{Vascularização do Corpo Lúteo}

O corpo lúteo é um dos tecidos mais vascularizados do corpo e durante seu rápido crescimento fisiológico, um intenso processo de angiogênese se inicia (ROBERTO DA COSTA et al., 2005; FERREIRA-DIAS et al., 2006; MULLER; ELLENBERGER; SCHOON, 2009) que é essencial para sua formação e desenvolvimento, resultando em uma rede capilar extensa (REDMER; REYNOLDS, 1996) e uma pronta produção de progesterona pela estrutura recém formada (FERREIRA-DIAS; MATEUS, 2003; ROBERTO DA COSTA et 
al., 2005). Sua regressão, por sua vez, envolve alterações e morte celular por apoptose das mesmas células vasculares que permitiram seu grande crescimento (AL-ZI'ABI et al., 2003; FERREIRA-DIAS et al., 2006).

O VEGF é apontado como o principal fator angiogênico no CL (REYNOLDS; REDMER, 1998; FRASER et al., 2000) e aparentemente ele é controlado mais pelo LH do que por hipóxia (NEULEN et al., 1998; DICKSON; FRASER, 2000). As células endoteliais chegam a constituir 85\% das células em proliferação do CL no início da fase luteal, e $50 \%$ do CL maduro de acordo com achados em ovinos (REYNOLDS et al., 1994).

A quantidade de capilares é tão grande que cada célula lútea pelo menos está em contato com um dos capilares recém formados (DHARMARAJAN; BRUCE; MEYER, 1985; ZHENG; REDMER; REYNOLDS, 1996). Exemplificando esta proximidade, 59\% das células luteais estavam diretamente adjacentes a um capilar e $37 \%$ adjacente ao tecido intersticial próximo a um capilar. Essa proximidade otimiza a função da glândula endócrina temporária de síntese de progesterona, pois fornece precursores necessários e uma eficiente distribuição da progesterona produzida para a circulação (AL-ZI'ABI et al., 2003).

Em ratos, demonstrou-se que $22 \%$ do volume do CL é somente a rede capilar. 0 fluxo sanguíneo para o corpo lúteo é de $6-10 \mathrm{~mL} / \mathrm{g} / \mathrm{min}$, sendo maior do que para os outros tecidos (DHARMARAJAN; BRUCE; MEYER, 1985). Além disso, fornece o suprimento de oxigênio gerado por esta glândula de alta demanda metabólica, que é 2 a 6 vezes maior do que para fígado, rim ou coração (SWANN; BRUCE, 1987). Portanto, uma insuficiente ou inadequada vascularização pode ser associada com função luteal alterada (REDMER; REYNOLDS, 1996).

Um aumento na área de microvascularização do CL nas fases iniciais e no meio do diestro ocorre apesar do número de vasos ser maior no meio e final do diestro. 0 aumento do número de vasos e diminuição das áreas vasculares pode ser explicado por uma diminuição no lúmen do vaso sanguíneo e contração do vaso, tendo aspecto de anéis concêntricos (FERREIRA-DIAS et al., 2006). Essa redução no diâmetro vascular pode levar a uma diminuição do fluxo sanguíneo, e iniciar ou acelerar o processo de regressão do CL (GÁYTAIN et al., 1999). No corpo albicans ocorre a oclusão dos vasos que desaparecem junto com a estrutura em regressão, reduzindo seu número e densidade (FERREIRA-DIAS et al., 2006). 
Uma série de fatores anti-angiogênicos provavelmente exercem função na regressão do CL e modulação da angiogênese como a angiostatina, endostatina, trombospondina e fator plaquetário quatro. Alguns destes fatores anti-angiogênicos podem participar também da formação do corpo lúteo para garantir que não ocorra uma vascularização excessiva e mediar apoptose durante a regressão luteal. As células do endotélio microvascular são as primeiras a sofrer apoptose, que aumenta na fase luteal tardia e a mitogênese endotelial diminui (FERREIRA-DIAS et al., 2006).

Por ser uma das partes mais vascularizadas do corpo na égua, a avaliação do fluxo sanguíneo do CL pode ser usada como indicador de integridade fisiológica no ovário (BERGFELT; ADAMS, 2011). 0 fluxo sanguíneo para o recém formado corpo lúteo foi avaliado utilizando ultrassonografia modo B e Color Doppler (GINTHER et al., 2007). Neste estudo, três regiões diferentes foram escaneadas a cada 12 horas até o dia 6 do ciclo, sendo elas o terço basal, médio e apical. 0 início da vascularização do corpo lúteo após a ovulação ocorreu na base, onde alguns vasos do folículo permaneceram. Notou-se então um padrão de vascularização crescente da base em direção ao ápice ao longo dos 6 próximos dias (6 dias pós ovulação) (GASTAL, 2011).

Outros estudos detectaram (BOLLWEIN et al., 2002; GINTHER et al., 2007a) um aumento progressivo nas concentrações plasmáticas de progesterona e porcentagem de fluxo sanguíneo no corpo lúteo até níveis máximos durante a primeira semana após a ovulação. Este padrão ocorreu nas éguas com ovulações denominadas de evacuação normal. Nas éguas com ovulações do tipo septadas foi notada outro tipo de vascularização, sendo que todas as partes do corpo lúteo eram vascularizadas desde o início, sugerindo que vasos de toda a periferia contribuam para a vascularização do novo corpo lúteo (GASTAL, 2011).

Um aumento no fluxo sanguíneo acontece entre os dias 0 e 5 pós ovulação (BERGFELT; ADAMS, 2011). De acordo com Bollwein et al. (2002), o número médio de pixels por imagem de CL atingiu valor máximo no dia 5, diminuiu entre 7 e 15 pós ovulação, sendo associado com a regressão luteal. Entre os dias 5 e 7 pós ovulação, atingem-se as maiores concentrações circulantes de progesterona, máxima vascularização e mínima ecogenicidade. Do 5ำ dia em diante, a vascularização do CL começa gradualmente a diminuir (BERGFELT; ADAMS, 2007; GINTHER et al., 2007b). 
A partir do $10^{\circ}$ dia pós ovulação, uma queda na progesterona indica regressão funcional do CL, em conjunto com uma diminuição do diâmetro e área, e redução no fluxo sanguíneo (GINTHER et al., 2007b; BERGFELT; ADAMS, 2011).

\subsubsection{Endocrinologia do Corpo Lúteo}

As concentrações séricas de progesterona são dependentes da quantidade de tecido esteroidogênico, fluxo sanguíneo e capacidade do tecido esteroidogênico de produzir progesterona. A quantidade de tecido esteroidogênico é dependente do número e tamanho das células luteais, que aumentam no decorrer do desenvolvimento luteal (NISWENDER et al., 2000).

Com o evento da ovulação, tanto estradiol como inibina caem no início do diestro (BERGFELT, 2009). Ocorre um aumento imediato de progesterona no momento da ovulação, iniciando-se cedo na fase luteal e acompanhada por um aumento nos receptores de progesterona e proliferação de células luteais grandes até o meio da fase luteal (ROBERTO DA COSTA et al., 2005).

Após a ovulação ocorrem aumentos periódicos de baixa magnitude de LH que serão luteotróficos e garantirão o desenvolvimento e manutenção do CL, e resultam no aumento das concentrações de progesterona. Paradoxalmente, este aumento da progesterona fará com que aconteça um feedback negativo no LH e consequente diminuição dos seus níveis até atingirem o nível basal novamente ao redor do dia 6 pós ovulação. As concentrações de progesterona vão aumentando até o dia 8 pós ovulação (GINTHER et al., 2007b; AURICH, 2011). A partir de então, as concentrações de progesterona diminuem levemente sem o suporte luteotrófico do LH e se mantêm moderada durante o meio e final do diestro (BERGFELT, 2009), quando decrescem até o momento da luteólise aproximadamente no dia 14 (AURICH, 2011).

\subsubsection{Esteroidogênese}

Em mamíferos, o CL produz 2 a 3 vezes mais esteroides do que o folículo (MURPHY, 2004). Na égua, é no meio da fase luteal que as concentrações de 
progesterona ficam altas e o número de receptores de progesterona nas células luteais grandes é maior. Estas células são as responsáveis pela regulação da síntese de progesterona nesta espécie. A queda de progesterona no final do diestro pode ser explicada pela redução no número de células luteais grandes (ROBERTO DA COSTA et al., 2005) por um feedback negativo autócrino-parácrino que ocorre no CL em regressão (RUEDA et al., 2000), ou por um mecanismo de dessensibilização à progesterona no CL (DIAZ; WILTBANK, 2004). O papel endocrinológico de produção de progesterona das células luteais pequenas em éguas não parece importante (ROBERTO DA COSTA et al., 2005), entretanto ainda não existe uma posição absoluta com relação a esta questão. Neste trabalho levanta-se o questionamento se a progesterona é luteotrófica ou luteolítica na égua, sugerindo um provável papel dual, tendo as duas funções em momentos diferentes (FERREIRA-DIAS et al., 2007).

A esteroidogênese necessita como substrato o colesterol, tornando essencial seu fornecimento constante (STOCCO; TELLERIA; GIBORI, 2007). Geralmente ele é sintetizado no fígado (KRISANS, 1996) e atinge o corpo lúteo transportado na forma de lipoproteínas. As duas formas mais comuns utilizadas para chegar ao CL são a lipoproteína de baixa densidade (LDL) e lipoproteína de alta densidade (HDL) (PATE; CONDON, 1982; HWANG; MENON, 1983), variando entre as espécies (STOCCO; TELLERIA; GIBORI, 2007).

O CL também é capaz de produzir colesterol a partir de acetato em situações com diminuição de lipídeos e in vitro. Entretanto, a maioria do colesterol é obtida da corrente sanguínea na forma de LDL e HDL (NISWENDER et al., 2000). A molécula de LDL possui 2500 moléculas de colesterol e seu transporte para as células luteais é por endocitose mediada por receptor. Os endossomos se unem aos lisossomos, fornecendo o LDL do seu receptor, liberando as moléculas de colesterol. 0 mecanismo de transporte com HDL difere do primeiro, sendo que a molécula se liga a proteína de membrana e o colesterol é transportado. Atualmente, receptor scavenger classe B tipo 1 (SR-BI) é considerado o mediador da entrada de HDL, sendo que o HDL permanece na superfície celular (ACTON et al., 1996).

Os colesteróis na célula formam gotas lipídicas que serão hidrolizadas pela colesterol esterase, ativada pela fosforilação da proteína quinase A (PKA). A primeira etapa no processo esteroidogênico é o transporte do colesterol para a membrana mitocondrial externa. A forma com a qual este transporte é realizado ainda não é 
esclarecida, entretanto devido a sua natureza hidrofóbica, o colesterol não é capaz de difundir pelo citosol e atingir a mitocôndria sem ligar-se às proteínas carreadoras. A proteína 2 carreadora de esterol (SCP-2) parece ter um papel no movimento intracelular do colesterol (SEEDORF; ELLINGHAUS; ROCH NOFER, 2000). Após sua chegada à membrana mitocondrial externa, o colesterol é transportado para a membrana mitocondrial interna passando pelo espaço aquoso intermembrana (STOCCO; TELLERIA; GIBORI, 2007).

O transporte do colesterol para a membrana mitocondrial interna é considerada o passo limitante na esteroidogênese. A proteína StAR (proteína esteroidogênica reguladora aguda), o receptor benzodiazepínico tipo periférico e o ligante endógeno deste receptor, além da lipase hormônio sensível são necessários para o transporte para a membrana mitocondrial interna, onde ocorrerá a clivagem da cadeia lateral do colesterol (NISWENDER et al., 2000; STOCCO; TELLERIA; GIBORI, 2007).

Após chegar ao seu destino, a membrana mitocondrial interna, o colesterol inicia a transformação para hormônio esteroide. A enzima clivadora de cadeia lateral P450 (P450scc) e a $3 \beta$-hidroxiesteróide desidrogenase, localizadas no retículo endoplasmático liso são comprometidas com a transformação do colesterol em progesterona. Um aumento importante na expressão destas duas enzimas ocorre na formação do CL (KAYNARD et al., 1992) e nas organelas nas quais elas se encontram, tornando-o capaz de produzir grandes quantidades de progesterona (STOCCO; TELLERIA; GIBORI, 2007). O colesterol é transformado em pregnenolona pela P450scc, que é transportada para o retículo endoplasmático liso, associado intimamente à mitocôndria. Nele, a 3- $\beta$ hidroxiesteróide desidrogenase converte a pregnenolona para progesterona, que vai difundir para fora da célula, não existindo evidência de armazenamento em grandes quantidades no tecido luteal (NISWENDER et al., 2000; VANDERWALL, 2011).

A distribuição da progesterona na corrente sanguínea é sistêmica e irá agir nas células alvo que contêm o receptor de progesterona (VANDERWALL, 2011).

Interessante é o fato de receptores de progesterona somente terem sido encontrados em células luteais grandes em equinos e a ausente ou inconsistente detecção de enzimas esteroidogênicas nas células luteais pequenas (ROBERTO DA COSTA et al., 2005; FERREIRA-DIAS et al., 2007). Supõe-se que as células luteais pequenas em éguas sejam apenas precursoras das células luteais grandes que 
aumentam em tamanho e função ao longo do desenvolvimento do CL (VAN NIEKERK et al., 1975; ROBERTO DA COSTA et al., 2005). Os dois tipos de célula luteal podem ser distinguidos morfológica e funcionalmente (LEI; CHEGINI; RAO 1991). Ambos estão presentes ao longo da formação, desenvolvimento e regressão do CL (FERREIRA-DIAS et al., 2002). A quantidade de células luteais grandes no CL recém formado foi menor do que no restante do ciclo. Notou-se um paralelismo entre as quantidades de células luteais grandes e produção de progesterona, provavelmente por elas terem um importante papel na síntese de progesterona.

No corpo albicans, apesar de não haver diferença na quantidade de células luteais grandes, as células apresentavam sinais de morte celular como degeneração citoplasmática (vacúolos e fragmentação) e nuclear. Portanto eram incapazes de síntese de progesterona. Diferindo destes achados, a quantidade de células luteais pequenas não variou no CL ao longo das diferentes fases (FERREIRA-DIAS et al., 2002).

Discordando desta afirmação, Watson (1999) demonstrou que células luteais pequenas têm a enzima esteroide $17 \alpha$-hidroxilase/17,20liase (citocromo P450c17), dando evidência do seu potencial esteroidogênico. Também identificaram células da teca entre as células luteais grandes no CL maduro (WATSON, 2000). Este mesmo grupo detectou produção in vitro de progesterona quando células luteais pequenas foram cultivadas, reforçando a hipótese anterior (BROADLEY et al., 1994), sendo que uma conclusão sobre este ponto ainda não foi alcançada.

\subsubsection{Alteração da Função Luteal}

Em um animal não gestante, espera-se que a duração do CL seja entre 14 e 15 dias (DAELS; HUGHES, 1993). Alterações nesta duração de fase luteal, seja ela diminuição ou aumento, são consideradas anormais. No passado, a persistência do corpo lúteo era denominada função luteal prolongada, independente de sua etiologia (GINTHER, 1992). Uma vez iniciada a utilização da ultrassonografia, um diagnóstico mais preciso de sua causa pode ser determinado, mostrando diversas origens tais como piometra, mucometra, ovulações secundárias e folículos anovulatórios hemorrágicos (GINTHER, 1992). 
Desta forma, o termo previamente utilizado foi substituído por termos mais apropriados. Quando detectada a alteração de função luteal caracterizada por aumento de duração devido à reduzida síntese ou secreção de $\mathrm{PGF}_{2 \alpha}$ como na piometra, nomeiase persistência de corpo lúteo uteropática. Quando a persistência luteal não apresenta aparente causa uterina ou ovariana, denomina-se persistência luteal idiopática (GINTHER, 1990).

Por outro lado, o termo abreviação do corpo lúteo uteropática foi sugerido para os casos nos quais ocorre uma lise precoce do corpo lúteo por síntese e secreção de $\mathrm{PGF}_{2 \alpha}$ prematura, geralmente associada com endometrite. Nestas circunstâncias o ciclo estral tem duração reduzida (GINTHER, 1990).

Insuficiência luteal por sua vez é definida como uma função luteal diminuída pelo mau funcionamento do corpo lúteo associado à perda embrionária precoce (IRVINE et al., 1990; BERGFELT et al., 1992), entretanto, parece ser um evento raro durante a estação ovulatória. Em éguas que foram retiradas do anestro com folículos menores do que $15 \mathrm{~mm}$ no início do tratamento e aplicado GnRH para induzir a ovulação, detectou-se disfunção do corpo lúteo precedendo a perda embrionária (BERGFELT et al., 1992).

\subsubsection{Luteólise}

Quando a gestação não é estabelecida, o CL sofre um processo de regressão funcional e estrutural, uma vez que a continuação da secreção de progesterona já não se faz mais necessária (BOWEN-SHAUVER; GIBORI, 2004; FERREIRA-DIAS; SKARZYNSKI, 2008). Neste momento, o CL diminui a síntese de progesterona com subsequente regressão estrutural (NISWENDER et al., 2000). Este processo é conhecido como luteólise e é essencial para a ciclicidade normal e permite o desenvolvimento de um novo folículo ovulatório (SKARZYNSKI; FERREIRA-DIAS; OKUDA, 2008).

A primeira alteração detectada de apoptose em células luteais ainda no dia 10 pós ovulação é a degeneração das mitocôndrias, que ocorre associada a diminuição na produção de progesterona uma vez que elas são as responsáveis pela esteroidogênese (AL-ZI'ABI et al., 2002). 
A luteólise é iniciada pela liberação de $\mathrm{PGF}_{2 \alpha}$ das células endometriais e é estimulada pela ocitocina de origem hipofisária, diferindo de outras espécies nas quais existe produção luteal. Além disso, o equino foi o único no qual a ocitocina foi identificada no endométrio (BAE; WATSON, 2003). O processo luteolítico na égua envolve um sistema parácrino-autócrino de ocitocina endometrial e $\mathrm{PGF}_{2 \alpha}$ sendo iniciado pela secreção endometrial de $\mathrm{PGF}_{2 \alpha}$ durante o final da fase luteal, que cai na circulação sistêmica, disparando o processo irreversível funcional e estrutural da lise do CL (GINTHER, 1992). Devido à grande afinidade de ligação do CL equino com a PGF , $_{2}$, ele se torna mais sensível à ação dela (AURICH, 2011).

São caracterizados dois tipos de luteólise na égua: funcional e morfológica. A luteólise funcional é definida por uma pronunciada diminuição das concentrações de progesterona ao redor dos dias 15 a 17 do ciclo (AL-ZI'ABI et al., 2002). A luteólise morfológica é mais lenta e tardia (GINTHER et al., 2005, 2007).

A luteólise funcional é associada com uma queda grande na expressão da P450 scc. Um aumento na expressão de marcadores apoptóticos nas células luteais ocorre, sinalizando morte celular. Paradoxalmente um grupo de células luteais ainda começa estados iniciais de divisão. A expressão de VEGF diminui já nos estágios iniciais de regressão, mas não ocorre antes da apoptose das células luteais. Este achado é um indício de que em equinos a morte das células endoteliais não antecipa a morte das células luteais e nem é iniciadora de luteólise, sendo que as duas ocorrem simultaneamente (AGUILAR et al., 2006; GINTHER et al., 2007a).

Já nos estágios iniciais de regressão luteal, um desarranjo dos capilares luteais seguido por apoptose das células endoteliais foi notado (MULLER; ELLENBERGER; SCHOON, 2009). Degeneração celular e desvascularização ocorrem durante a regressão luteal (BERGFELT; ADAMS, 2011).

Sugere-se que o sistema IGF desempenhe um papel importante também na função luteal, sendo que um aumento na proteína 2 ligadora de fator de crescimento tipo insulina (IGFBP-2) pode reduzir a biodisponibilidade de IGF no CL no momento da luteólise, retirando o efeito estimulatório de esteroidogênese e protetor contra a apoptose (WATSON et al., 2005).

A exposição prolongada à progesterona no meio da fase luteal parece inibir a atividade angiogênica, contrariamente ao efeito estimulatório da síntese de progesterona no início da formação do CL. Talvez este já seja um passo inicial de 
preparação do CL para a lise. O óxido nítrico também pode estar envolvido neste processo, provocando efeito antagônico ao seu próprio durante a fase de formação luteal (FERREIRA-DIAS et al., 2006b).

INF $\gamma$ e TNF $\alpha$ em ação sinérgica causaram aumento na síntese de $\mathrm{PGF}_{2 \alpha}$ luteal , diminuição na viabilidade celular e aumento de apoptose em células de corpo lúteo em regressão in vitro, sendo implicados pelos autores do trabalho como parte importante no processo de luteólise (GALVÃO et al., 2012).

Em éguas não gestantes ocorre um aumento da expressão da COX- 2 nas células uterinas epiteliais, enquanto em éguas prenhes essa expressão é inibida. Baseado nesses achados considera-se a expressão da COX-2 um evento chave na luteólise ou reconhecimento materno da gestação (BOERBOOM et al., 2004).

A luteólise na égua é mediada por mecanismos de apoptose e não apoptóticos, tais como diminuição de volume, crenação e involução da membrana nuclear, conhecido como diferenciação terminal (AL-ZI'ABI et al., 2002). Foi detectado no tecido luteal após a fase inicial do diestro o dobro da expressão da caspase-3 comparado com o início (FERREIRA-DIAS et al., 2007), incluindo as células luteais grandes. Um acúmulo de lipídios no citoplasma foi encontrado em células no dia 17 do ciclo, sendo uma característica da regressão luteal. A presença de macrófagos também foi notada, internalizando corpos apoptóticos e células luteais degeneradas (AL-ZI'ABI et al., 2002).

A luteólise completa ao redor do dia 17 se caracteriza por níveis de progesterona abaixo de 2ng/ml (BERGFELT, 2009).

\subsubsection{Progesterona}

A progesterona foi desta forma nomeada, pois um nível adequado de progesterona e/ou progestágenos relacionados são essenciais para a manutenção de gestação na maioria dos mamíferos, tornando-a o hormônio pró-gestacional (VANDERWALL, 2011). Os níveis circulantes de progesterona são relacionados a formação, manutenção e luteólise (GINTHER; BEG, 2012). Ela age no trato reprodutivo com o objetivo de prepará-lo para o início e manutenção da gestação (NISWENDER et al., 2000). 
Em éguas gestantes ou vazias, os eventos iniciais de formação do corpo lúteo e secreção de progesterona são os mesmos. Entretanto a presença do concepto no lúmen uterino inibe a secreção de $\mathrm{PGF}_{2 \alpha}$, no momento esperado para luteólise, o que resulta na secreção contínua de progesterona pelo corpo lúteo (ALLEN, 2000).

Um aumento detectável de progesterona circulante é primeiro encontrado entre 10 e 12 horas após a ovulação, com uma variação grande individual entre 6 e 60 horas (PLOTKA et al., 1975; TOWNSON et al., 1989). O nível acima de $1 \mathrm{mg} / \mathrm{mL}$ de progesterona é considerado marcador do início do diestro (NEELY et al., 1979). Este aumento acontece de forma rápida e contínua, sendo que os níveis máximos são atingidos entre os dias 6 e 9 pós ovulação, seguido de um platô (HUGHES et al., 1972; ARRUDA et al., 2001).

As concentrações de progesterona também podem ser muito diferentes, não sendo raro encontrar valores díspares entre estudos. Alguns pesquisadores encontraram no dia 5 a 7 uma concentração plasmática máxima de aproximadamente $10 \mathrm{ng} / \mathrm{mL}$ e ela manteve-se relativamente constante até o dia 13 ou 14, quando a luteólise aconteceu em animais não gestantes (HOLTAN et al., 1979). Souza (2006) encontrou níveis de progesterona mais elevados dos que os descritos previamente na literatura, sendo que o grupo controle apresentou $8,42 \mathrm{ng} / \mathrm{ml}$ no dia 4 pós ovulação, e 16,08 no dia 8 pós ovulação. Nos grupos nos quais foi administrada a hCG para induzir a ovulação ou no dia 1 pós ovulação, as concentrações de progesterona no dia 4 foram de 16,01 e 14,85ng/mL, respectivamente. Nestes mesmos grupos, no dia 8, 16,08 e 17,31ng/mL. Arruda et al. (2001) encontraram valores em torno de 4ng/mL entre os dia 5ํ e 9o dia pós ovulação. Portanto, um cuidado ao comparar os níveis de progesterona descritos em cada estudo deve existir.

Grandes alterações comportamentais e fisiológicas no eixo hipotálamohipofisário-gonadal e no sistema reprodutivo da égua acompanham temporalmente as alterações nos níveis sistêmicos de progesterona. Estas mudanças são essenciais para que a atividade reprodutiva aconteça normalmente e para que uma boa fertilidade seja alcançada (VANDERWALL, 2011).

A progesterona exerce suas funções ligando-se aos seus receptores cujas duas isoformas diferem na ação biológica e farmacológica, os tipos A e B (PINTO, 2011). Enquanto o receptor de progesterona A (PRA) age como inibidor transcripcional e modulador para outros receptores esteroides incluindo o receptor de progesterona $\mathrm{B}$ 
(PRB), este é responsável pelos efeitos progestacionais típicos e derivativos (GIANGRANDE; MCDONNEL, 1999).

Sua ligação ao seu receptor no núcleo, e o complexo formado pelo receptor e progesterona irá atuar como um fator de transcrição que se liga aos elementos de resposta da progesterona no ácido desoxiribonulceico (DNA). 0 resultado desta ligação pode ser estimular a expressão de genes específicos, que irão sintetizar proteínas ou desligar a expressão de genes específicos, que inibirão a síntese proteica de uma maneira progesterona-dependente (NISWENDER et al., 2000).

A exposição prévia ao estrógeno, que aumenta a expressão de receptores de progesterona no trato reprodutivo é necessária para que ela possa agir (HARTT et al., 2005). A progesterona causa uma diminuição nos receptores de estrógeno, bloqueando desta forma várias ações dos estrógenos que agem como fatores mitogênicos. No oviduto, por exemplo, a progesterona bloqueia as proteínas secretórias (VERHAGE; FAZLEABAS, 1988) induzidas por estrógeno e causa deciliação e parada da atividade secretória do epitélio do oviduto (SAWYER; OLSON; GORELLI, 1984).

As alterações na expressão gênica provocam mudanças na atividade celular e dependendo do órgão alvo, elas podem ter efeitos locais (atividade secretória no lúmen uterino e tônus uterino e cervical) ou sistêmicos (alteração secretória no eixo hipotálamo-hipofisário-gonadal) (VANDERWALL, 2011).

Além do mecanismo conhecido de ação genômica, outro modo de ação não genômico foi proposto para a progesterona e outros hormônios esteroides. Este mecanismo seria de ação rápida, que não irá alterar expressão gênica e síntese proteica. A ocorrência e importância desta via de ação da progesterona em éguas ainda são desconhecidas (BISHOP; STORMSHAK, 2008).

Um efeito notável da progesterona é a influência no comportamento reprodutivo (CROWELL-DAVIS, 2007). Os níveis abaixo de $1 \mathrm{ng} / \mathrm{mL}$ de progesterona durante o estro são permissivos, fazendo com que a receptividade ao macho seja demonstrada sob efeito do estrógeno. Com o desenvolvimento do corpo lúteo após a ovulação e consequente aumento das concentrações de progesterona acima de $1 \mathrm{ng} / \mathrm{mL}$, o comportamento de estro é bloqueado.

Estrógeno e progesterona possuem efeitos de feedback positivo ou negativo sobre o eixo hipotálamo-hipofisário-gonadal, que por sua vez regulam vários eventos reprodutivos que são importantes para a fertilidade normal (VANDERWALL, 2011). A 
progesterona apresenta efeito inibitório sobre a secreção de LH (GINTHER et al., 2006) e não afeta a secreção de FSH (GARCIA et al., 1979).

A progesterona pode ter efeitos sinérgicos ou antagônicos com o estrógeno nos tecidos alvo. Enquanto o estrógeno estimula a expressão de receptores de progesterona (efeito sinérgico), a progesterona inibe a expressão de receptores de estrógeno (efeito antagônico) (NISWENDER et al., 2000). A progesterona é dominante sobre o estrógeno e pode ser notada quando se aplica ambos os hormônios para éguas anovulatórias ou ovariectomizadas, que resulta predominantemente em efeitos progestacionais (HAYES; GINTHER, 1986).

No útero, a progesterona:

- age como um fator de diferenciação estromal, inibe a mitose das células do endométrio (PADYKULA et al., 1989);

- estimula secreções glandulares associado com o acúmulo de vacúolos basais no epitélio glandular (MASLAR et al., 1986);

- muda o padrão de proteínas secretadas pelas células endometriais para nutrir o concepto (ZAVY et al., 1984);

- estimula a quiescência do miométrio, com elevado potencial de repouso e inibição da junção entre as células miometriais (PARKINGTON, 1983);

- reduz a entrada de cálcio nas células miometriais (BATRA, 1986) por diminuir a expressão dos genes que codificam as subunidades dos canais de cálcio voltagem dependentes (TEZUKA et al., 1995);

- diminui a contratilidade uterina bloqueando a ação indutora do estradiol sobre os receptores $\alpha$ adrenérgicos cuja ativação causa contração (BOTTARI et al., 1983).

Entre todos os efeitos mencionados da progesterona nos eventos reprodutivos na égua, talvez o mais importante pró-gestacional seja a regulação da secreção das glândulas uterinas, coletivamente denominadas de histotrofo uterino, que regulará o ambiente luminal para o desenvolvimento do concepto. Em sua composição, podemos citar moléculas bioativas (proteínas, carboidratos, esteroides, prostaglandinas, íons entre outros). Como suas propriedades essenciais, um sistema de troca metabólica de nutrientes e subprodutos entre concepto e endométrio é estabelecido enquanto a placenta não desempenha esta função. A osmolaridade necessária é mantida, garantindo um ambiente adequado, inclusive satisfazendo os requerimentos imunológicos e antibacterianos. Além disso, a mobilidade do embrião é facilitada pois este lubrifica o 
ambiente uterino, permite adesividade do concepto para que este se posicione e oriente de forma correta no útero (GINTHER, 1992; VANDERWALL, 2011).

Deve-se lembrar que o embrião equino é totalmente dependente das secreções uterinas durante o início do seu desenvolvimento, para seu suporte nutricional e metabólico por não haver uma superfície de contato íntimo de troca entre embrião e útero até um momento futuro da gestação (VANDERWALL, 2011). Já foi demonstrada que a habilidade de o endométrio provir quantidade adequada de secreções depende em grande parte da progesterona, visto que o total de proteína na secreção uterina ao longo do ciclo estral foi estudado e os resultados indicaram que o conteúdo total caiu abruptamente com o declínio da progesterona.

Zavy et al. (1982) notaram que somente após a aplicação de progesterona ou progesterona com estrógeno eram encontrados produtos secretórios no útero enquanto que o estrógeno não era capaz de causar este mesmo efeito, com isto fica clara que essas secreções são progesterona dependentes (ZAVY et al., 1982).

Após a manutenção do corpo lúteo, e consequentemente da secreção de progesterona, o conteúdo proteico da secreção uterina permanece elevado (ZAVY et al., 1979). A progesterona está associada com secreção de uteroferrina (SHARP, 1992), que parece ser tempo dependente, ocorrendo brevemente após a exposição do endométrio ao estrógeno seguido de progesterona (HINRICHS; KENNEY; SHARP, 1989). Fica evidenciado, portanto o papel fundamental da progesterona neste contexto.

O corpo lúteo primário é a fonte principal de progesterona ao longo dos 40 dias inicias da gestação, quando corpos lúteos adicionais serão formados pela ação do FSH da hipófise e do eCG produzido pelos cálices endometriais no útero. A unidade fetoplacentária se torna a fonte de síntese e secreção principal de progesterona/progestágenos em éguas gestantes deixando o CL primário de ter papel fundamental na manutenção da gestação (ALLEN, 2001).

\subsubsection{Perda Embrionária e Progesterona}

A perda embrionária representa uma importante causa de perda financeira e emocional para criadores, visto que entre 15 e $20 \%$ das prenhezes diagnosticadas no 
dia 15 pós ovulação não chegarão a termo. Cerca de $63 \%$ de todas estas perdas acontecem até o dia 40 pós ovulação (STOUT, 2009), momento durante o qual a progesterona luteal possui suma importância para vários mecanismos associados com o início da gestação. Permanece discutível se uma deficiência no desenvolvimento luteal ou na produção de progesterona podem resultar em menor taxa de prenhez. Em equinos, existe um intenso debate acerca dos resultados conflitantes responsabilizando a insuficiência luteal primária como causadora de falha de estabelecimento da gestação (IRVINE et al., 1990; GINTHER, 1992; ALLEN, 2001).

0 reconhecimento materno da gestação em éguas ocorre entre os dias 10 e 14 após a ovulação (GINTHER, 1992), sendo o corpo lúteo primário o responsável pela manutenção da gestação pelas próximas 3 a 4 semanas. Durante este período, as concentrações de progesterona podem diminuir a níveis mais baixos do que os primeiros 10 dias de gestação (ALLEN, 2001).

Aproximadamente 60\% das perdas embrionárias precoces ocorrem entre os dias 15 a 35 pós ovulação (MORRIS; ALLEN, 2002). Em aproximadamente 10\% das éguas férteis, a perda embrionária ocorre precocemente, e as éguas subférteis sofrem perda mais frequentemente e até uma fase mais avançada da gestação (ADAMS et al., 1987), provavelmente tendo relação com a pior qualidade dos embriões em comparação às éguas novas (BRINSKO et al., 1994).

O crescimento e desenvolvimento insuficiente do concepto são considerados causas importantes de perda embrionária precoce. Em embriões com tamanho anormal a taxa de perda é maior do que em embriões de tamanho normal (GINTHER et al., 1985; WOODS et al., 1986; ADAMS et al., 1987; BERGFELT; GINTHER, 1991).

Considerando-se a perda precoce de gestação até aproximadamente dia 20 pós ovulação uma causa importante de baixa eficiência reprodutiva em éguas subférteis (MORRIS; ALLEN, 2002) e o CL primário a única fonte de progesterona durante o período embrionário da gestação, muitos temem a insuficiência luteal primária. Ela já foi descrita por Bergfelt et al. (1995), e hoje um grande número de éguas é suplementado com progesterona ou progestágenos exógenos para prevenir a perda embrionária (PYCOCK, 2009), sendo o tratamento de éguas com histórico de repetidas perdas embrionárias precoces com o progestágenos altrenogest se tornou rotina (ALLEN, 2001). 
Abaixo serão revisados alguns trabalhos que estudaram o aspecto de perda embrionária e sua relação com a progesterona.

Concentrações reduzidas de progesterona podem ser associadas com perda embrionária espontânea e podem envolver luteólise induzida por endometrite, falha do concepto de bloquear a luteólise e a insuficiência luteal primária (BERGFELT et al., 1992).

Irvine et al. (1990) mensuraram o nível de progesterona de 179 éguas gestantes do dia 16 a 45 de gestação. Um total de 17 éguas sofreu perda embrionária, sendo que em apenas uma delas houve a queda da progesterona antecedendo a perda. Uma biópsia uterina foi realizada, e 7 das 17 éguas tinham grau IIB e III. Concluiu-se, portanto, que a perda embrionária entre os dias 18 e 45 raramente seria causada por insuficiência de progesterona (IRVINE et al., 1990).

No mesmo sentido, Papa et al. (1994) avaliaram a causa da perda embrionária acompanhando as concentrações de progesterona de éguas prenhes. As concentrações de progesterona das éguas que sofreram perda ou não foram semelhantes e todos os animais que apresentaram perda embrionária apresentavam sintomas de endometrite aguda ou crônica, com graus de biópsia uterina variando de IIA (n=2), IIB (n=14) e III $(\mathrm{n}=1)$. A endometrite foi considerada como a principal causa da perda embrionária. Apesar das éguas apresentarem o endométrio comprometido, nenhuma delas sofreu luteólise secundária, também inocentando a insuficiência luteal primária como causadora.

Adams et al. (1987) observaram que éguas com fluido intraluminal apresentaram menor taxa de gestação, maior perda embrionária e menor concentração de progesterona no dias 8 do que éguas sem fluido intraluminal. Com isso, concluíram que a baixa taxa de prenhez nas éguas com fluido era decorrente de uma inflamação uterina e subsequente queda na concentração de progesterona devido à luteólise e não por insuficiência luteal primária.

Em alguns trabalhos, detectou-se queda de progesterona em alguns dos animais na qual a perda antes dos 20 dias pós ovulação foi detectada. De 13 éguas, 10 tiveram queda de progesterona de acordo com Bergfelt, Woods e Ginther (1992) e Newcombe (1997) encontrou o mesmo perfil em 5 de 11 animais por ele avaliados. Entretanto algumas outras alterações tais como tamanho da vesícula menor do que esperado para a data também foram descritos por estes autores. 
Um recente relato de caso sobre insuficiência luteal e suplementação de progesterona foi descrito, no qual a égua foi avaliada para diagnóstico de gestação aos 15 dias pós ovulação e uma vesícula pequena para a fase da gestação foi encontrada, tônus uterino e cervical eram pobres, não foi detectado CL ao exame ultrassonográfico e a concentração plasmática de progesterona era de 0,67 ng/mL. Suplementação com altrenogest foi prontamente iniciada e a gestação foi mantida até o nascimento de um potro saudável. Os autores sugerem que neste caso uma regressão prematura, caracterizando uma insuficiência luteal primária foi encontrada, entretanto esta regressão pode ter sido causada por uma incapacidade do embrião, que estava menor do que o esperado para a idade gestacional, de realizar o reconhecimento materno da gestação (CANISSO; BELTAIRE; BEDFORD-GUAUS, 2013).

Uma discussão no que diz respeito aos valores mínimos de concentração de progesterona para manutenção de gestação existe. Shideler et al. (1982) falam em 4 ng/mL como sendo o valor crítico enquanto Douglas et al. (1985) citam o nível de 2,5 ng/mL. Outro estudo também indicou o nível de 2,5 ng/mL como sendo o mínimo requerido para a manutenção da gestação e nele foi verificado que altas concentrações de progesterona $(>20 \mathrm{ng} / \mathrm{mL})$ não incrementam as taxas de prenhez. Quando as concentrações de progesterona estavam entre 2,2 e 25,2 ng/mL não houve alteração nas taxas de prenhez e na perda embrionária (KNOWLES et al., 1993).

De acordo com Allen (1974), a concentração de progesterona de $2 \mathrm{ng} / \mathrm{mL}$ foi suficiente pra manter a gestação. Acredita-se existir um nível mínimo individual de progesterona abaixo do qual a prenhez pode estar ameaçada, provavelmente resultando em uma habilidade alterada do útero de secretar proteínas necessárias para os requerimentos do concepto (BALL, 1988; ALLEN, 2001).

Em éguas, a presença da progesterona é um pré requisito para a mobilidade do concepto assim como a subsequente fixação e orientação no útero (KASTELIC et al., 1987). Nos resultados de um experimento, o desenvolvimento do embrião foi limitado em éguas com mais de 8 anos comparando-se com éguas entre 4 e 8 anos. Em éguas idosas, o tamanho da vesícula embrionária, do embrião e feto era menor do que em éguas jovens (WILLMANN et al., 2011b). 0 tamanho das vesículas embrionárias que sofreram perda embrionária era menor do que as vesículas controle que se mantiveram gestantes (GINTHER et al., 1985). Embriões menores, com vesículas menores e fetos em 
éguas idosas podem ser devido a uma menor qualidade oocitária. Entretanto, mesmo estes sobreviveram.

Surpreendentemente, o tamanho menor do embrião no dia 30 e do feto entre os dias 35 e 45 em éguas idosas foi melhorado pelo tratamento com altrenogest. 0 tamanho da vesícula embrionária, por outro lado, não foi afetado pelo tratamento, em concordância com o trabalho de Voller et al. (1991). 0 período entre 30 e 45 dias de gestação é aquele que corresponde ao final da organogênese e início da placentação, que é uma fase crítica da gestação. Efeitos positivos do altrenogest no leite uterino, que garante a nutrição do concepto até a placentação, são plausíveis (ALLEN; WILSHER, 2009). Os achados do presente estudo com relação ao efeito benéfico do altrenogest no desenvolvimento embrionário e fetal de éguas acima de 8 anos pode justificar a indicação do tratamento de éguas idosas ou com histórico de perda embrionária precoce para manter o desenvolvimento do concepto (WILLMANN et al., 2011b).

\subsection{GONADOTROFINA CORIÔNICA HUMANA (hCG)}

A gonadotrofina coriônica humana tem relatada ação no corpo lúteo e em taxa de prenhez e concentração plasmática de progesterona em diversas espécies, e foi utilizada neste presente estudo por estes efeitos. A molécula, mecanismo de ação e os principais trabalhos relatando estes resultados serão citados.

\subsubsection{Molécula}

A hCG é produzida pelas vilosidades coriônicas da placenta humana (NEWCOMBE, 2011), especificamente no retículo endoplasmático rugoso (BIELINSKA; BOIME, 1979) dos sinciciotrofoblastos (MEDEIROS; NORMAN, 2009), que são células responsáveis pela invasão do endométrio pelo embrião humano. Ela é detectada precocemente após a concepção e atinge o pico em torno de 35 a 50 dias (NEWCOMBE, 2011). 
Os pesquisadores Ascheim e Zondek (1927) foram os primeiros a detectarem uma substância estimulante de gônada na urina e sangue de mulheres gestantes. Logo em seguida, em 1931, a empresa Organon lançou o produto Pregnon, que se tornou Pregnyl no mercado e permanece até os dias de hoje (LUNENFELD, 2004).

A hCG faz parte do grupo dos hormônios glicoproteicos que incluem LH, FSH e TSH (STENMAN et al., 2006), seu peso é de 38000Da com 237 aminoácidos, organizados em duas unidades alfa e beta, ligadas de forma não covalente (COLE, 2009), cada uma consistindo em uma única cadeia de polipeptídeos (MEDEIROS; NORMAN, 2009), contendo galactose e hexosamina. Sua estrutura é divida em $70 \%$ de cadeias proteicas e 30\% de unidades de carboidrato (KEAY et al., 2004).

Todos os hormônios glicoproteicos são formados por essas duas subunidades $\alpha$ e $\beta$, diferentes. A subunidade $\alpha$ é formada por uma sequência de aminoácidos comum a todos os hormônios glicoproteicos, sendo a $\beta$ única e responsável pela atividade biológica. A hCG e LH possuem $80 \%$ de homologia entre as subunidades $\beta$, sugerindo uma função biológica comum, fazendo com que ambos se liguem ao mesmo receptor (LAPTHORN et al., 1994).

\subsubsection{Mecanismo de Ação}

Após a aplicação da hCG, existe um padrão bifásico da meia vida, sendo que a primeira ocorre entre 5 e 9 horas, chamada de fase rápida e segunda inicia-se de 24 a 33 horas (STENMAN et al., 2006), sendo a fase lenta. Esta diferença de meia vida se deve à presença do acido siálico na molécula, conferindo uma menor metabolização pelo fígado, aumentando o período de permanência no plasma (HERSHMAN, 2004)

A hCG se liga a um receptor específico na membrana da célula alvo tanto no trato reprodutivo como no restante do organismo, o receptor de hCG/LH. São receptores de alta afinidade por serem membros da família A tipo rodopsina/ $\beta_{2}$ adrenérgico (GPCR) ligados à proteína G. Ele apresenta um grande domínio extracelular e um pequeno intracelular, ligados por hélices transmembranas (MENON; MENON, 2012).

A ativação do receptor ocorre pela quebra das pontes de hidrogênio presentes nas hélices internas do receptor, levando a uma mudança de conformação, que ativará a 
proteína $G$ e consequentemente a adenilatociclase, aumentando os níveis de AMPc intracelular. Tanto a adenilatociclase como o AMP cíclico vão causar fosforilação de proteínas, consequentemente estas proteínas interagem com o DNA, levando à ativação de genes (MENON; MENON, 2012).

A hCG apresenta atividade tipo LH na maioria das espécies e promove a ovulação e desenvolvimento do corpo lúteo (PATTON; STOUFFER, 1991). Seu efeito em cavalos é mimetizar o LH, além disso de aumenta as concentrações endógenas de LH após sua administração (GINTHER et al., 2010).

A maior meia vida da hCG e maior potência (6 a $8 \times$ a do $L H$ ) permitem uma ocupação estável e efetiva de seus receptores, e seu clearance é menor (FILICORI et al., 2005).

Além dos efeitos acima mencionados, alguns estudos demonstraram ação tireotrópica da hCG em humanos e hamsters e uma alta sensibilidade do receptor de TSH (hormônio tireoestimulante) equino ao hCG. Com isso, Rizzo et al. (2009) delinearam um experimento no qual 40 éguas divididas em dois grupos foram inseminadas. Um primeiro grupo recebeu hCG quando um folículo pré ovulatório foi detectado e um segundo grupo recebeu solução salina. Concentrações de $\mathrm{T}_{3}$ e $\mathrm{T}_{4}$ foram mensuradas antes da aplicação e 2, 6, 24 hs, 3 e 6 dias após o tratamento. $0 \mathrm{~T}_{4}$ aumentou e permaneceu elevado por 2 dias no grupo que recebeu hCG, sugerindo um efeito da hCG. Este trabalho nos mostra que outras ações, além daquelas conhecidas e esperadas podem estar ocorrendo com a utilização da hCG.

\subsubsection{Utilização da hCG em outras Espécies}

Em animais domésticos, a ação tipo LH da hCG é maior do que do LH endógeno, tornando sua utilização interessante, pois apresenta uma meia vida maior, persistindo por mais tempo na circulação. A ligação da hCG na membrana das células luteais mais longa foi demonstrada por Schmitt et al. (1996) que marcaram a hCG com substância radioativa e perceberam que a ligação dela era maior nas células luteais comparado com 
o $\operatorname{LH}(22,8 \pm 2,3 \mathrm{~h}$ e $0,4 \pm 0,2 \mathrm{~h})$ tornando o efeito estimulatório da hCG maior durante a fase luteal.

Estudos utilizando hCG durante a fase luteal visando uma melhoria nos índices reprodutivos foram realizados em diversas espécies. Entretanto, os resultados encontrados na literatura são controversos no que diz respeito à verdadeira eficiência da hCG neste aspecto e os mecanismos envolvidos. A seguir, serão citados alguns dos trabalhos que mostraram efeitos positivos e a ausência de efeitos nas diferentes espécies.

Em bovinos, alguns trabalhos sugerem que a hCG possui uma importante e potente ação LH que aumenta a duração do corpo lúteo. Supõe-se então que a administração de hCG após a inseminação em momentos específicos pode estimular a função do CL (efeito luteotrófico), aumentando consequentemente a produção de progesterona (SIANANGAMA; RAJAMAHENDRAN, 1992), induzindo a formação de CL acessórios no início da fase luteal (RAJAMAHENDRAN; SIANANGAMA, 1992) e reduzindo a produção de estrógenos com um efeito positivo na sobrevivência embrionária (HANSEL; BLAIR, 1996; THATCHER et al., 2006), além de modificar a dinâmica de ondas foliculares aumentando a frequência de perfil com 3 ondas (DIAZ et al., 1998).

O efeito luteotrófico é atribuído às alterações que ocorrem no CL. A diferenciação das células da teca e granulosa para células luteais grandes e pequenas e a de células luteais pequenas para grandes são estimuladas pela indução da ovulação do folículo dominante pela hCG (FARIN et al., 1988; SIANANGAMA; RAJAMAHENDRAN, 1992). Esta mudança do corpo lúteo faz com que aumente sua capacidade esteroidogênica (SIANANGAMA; RAJAMAHENDRAN, 1992; SCHMITT et al., 1996; MACHADO et al., 2008).

A maioria dos receptores de LH estão nas células luteais pequenas (FITZ et al., 1982) e estas são transformadas em células luteais grandes durante o desenvolvimento do CL (SIANANGAMA; RAJAMAHENDRAN, 1992; DIAZ et al., 1998), aumentando sua área, volume e diâmetro (RAJAMAHENDRAN; SIANANGAMA, 1992; SIANANGAMA; RAJAMAHENDRAN, 1992; SANTOS et al., 2001).

Em um estudo em bovinos verificou-se um aumento nas concentrações plasmáticas de progesterona nos dias 5 a 12 do ciclo estral quando os animais não apresentavam corpos lúteos acessórios (DE RENSIS et al., 2008; MACHADO et al., 2008), demonstrando este efeito estimulatório no CL. Corroborando com este trabalho, o 
tratamento com hCG aumentou o peso total do CL em ovelhas e bovinos (NEPHEW et al., 1994; SCHMITT et al., 1996) e os autores acreditam que as respostas pareceram ser devido ao efeito direto desta gonadotrofina na hipertrofia e/ou aumento de fluxo sanguíneo para o CL (FARIN et al., 1986).

Beindorff et al. (2009) em trabalho in vivo em vacas demonstrou um aumento de fluxo sanguíneo no CL 1 hora após a aplicação da hCG (3000UI no dia 7). Entretanto, este aumento não foi mais detectado às $3 \mathrm{~h}$ após o tratamento. 0 aumento de concentração de progesterona só foi estatístico entre 6 e 48h após a aplicação. Aparentemente a hCG aumentou mais a concentração de progesterona às $48 \mathrm{~h}$ mas não apresentou diferença estatística. De acordo com os resultados encontrados neste estudo e em estudos prévios, um efeito da hCG no CL e não a formação de CLs acessórios foi o causador do aumento da progesterona (BEINDORFF et al., 2009).

Para fortalecer está hipótese, analisando tecido luteal de ratos, foi notado um aumento de concentração de progesterona após $200 \mathrm{~min}$ da exposição à hCG (NORJAVAARA et al., 1987). Um efeito direto da hCG na síntese luteal de progesterona foi encontrado em modelo de microdiálise do corpo lúteo. Foi demonstrado que o padrão de secreção de progesterona é dependente da localização da célula dentro do CL (BEINDORFF et al., 2009), sendo que um aumento foi notado na progesterona nas áreas centrais em reposta a 150UI/mL hCG, enquanto a parte periférica não apresentou resposta. Surpreendentemente, partes periféricas perfundidas com Ringer mostraram um aumento de progesterona comparado com os níveis basais. Após este momento, os níveis aumentaram, mas não significativamente ou mostraram valores estáveis. Estes resultados claramente indicaram um efeito direto positivo da hCG no tecido luteal com subsequente aumento de síntese de progesterona (BEINDORFF et al., 2009).

Outros estudos mostraram um efeito positivo da hCG nas taxas de prenhez quando aplicada nos dias 5 a 7 após a inseminação artificial (IA) em vacas (SIANANGAMA; RAJAMAHENDRAN, 1992; SANTOS et al., 2001). Em vacas repetidoras de cio também houve um incremento nas taxas de prenhez quando aplicada nos dias 5 e 6 pós IA (KHORAMIAN et al., 2011).

De acordo com Stevenson et al. (2008) a hCG em vacas de leite foi capaz de aumentar a concentração plasmática de progesterona nos animais que tiveram formação de CLs acessórios quando aplicada no diagnóstico de gestação, mas não reduziu a perda embrionária comparada com animais controle. 
Por outro lado, outros estudos nos quais a hCG foi aplicada entre os dias 5 e 14 pós IA, perceberam aumento na taxa de prenhez e sobrevivência embrionária em bovinos (KERBLER et al., 1997; SANTOS et al., 2001).

Em propriedades nas quais os índices de prenhez são baixos, notou-se uma melhora com a utilização da hCG (GOMEZ-BRUNET et al., 2007). No caso de bovinos de leite que sabidamente sofrem com os efeitos de estresse térmico nos meses quentes do ano, a hCG aplicada no momento da IA teve um efeito positivo refletido em menor perda embrionária (DE RENSIS et al., 2008). Talvez o efeito seja mais evidente quando os animais encontram-se em condições de estresse.

Nishigai et al. (2002) encontraram diferença entre as taxas de prenhez de receptoras bovinas quando receberam hCG no dia 6 comparado com aquelas que eram controle ou receberam hCG no dia 1, reiterando desta forma que a formação de CL acessório e aumento na concentração de progesterona reduzem mortalidade embrionária em bovinos.

Em cabras, animais tratados com hCG tanto no d0 e 1 como no d0, 1 e 2 tiveram as concentrações plasmáticas de progesterona superiores no dia 2 sugerindo que a hCG tenha alterado a proporção de células luteais pequenas e grandes. Desta forma, mudando a produção total de progesterona pelo CL - $80 \%$ da progesterona luteal é produzida pelas células luteais grandes (NISWENDER et al., 2000). Em cabras, o efeito luteotrófico da hCG reportado por Saharrea et al. (1998), foi notado uma vez que nenhuma cabra superovulada sofreu regressão luteal no dia 6 pós ovulação quando tratadas com hCG, problema comum encontrado nesta espécie. Em concordância com estes resultados, Shabankareh et al. (2012) também demonstraram o efeito positivo do tratamento com hCG pós ovulação, refletido em maior concentração plasmática de progesterona e nenhum dos animais superovulados tratados sofreu lise precoce do corpo lúteo.

Khan et al. (2003) aplicou hCG 150UI em borregas no dia da cobertura após protocolo de sincronização de estro e encontrou um crescimento aumentado do concepto, maior área de placentação e maior número de cordeiros nascidos comparado com os animais do grupo controle. Mais tarde, este mesmo grupo aplicou hCG no dia 12 pós cobertura e avaliou a função ovariana e a performance reprodutiva dos animais, sendo um grupo coberto durante a estação reprodutiva e outro no anestro. Os 
resultados mostraram que CLs acessórios foram formados em ovelhas e a sobrevivência embrionária aumentou, porém este efeito não foi notado em borregas.

Em búfalas, a hCG também foi utilizada com o intuito de aumentar a concentração de progesterona, aumentar taxa de prenhez e reduzir a perda embrionária. Um primeiro experimento no qual foi aplicada hCG no dia 5 pós IA, a concentração de progesterona foi significativamente maior do que o grupo controle no dia 15 , entretanto não houve diferença na taxa de prenhez e perda embrionária (CAMPANILE et al., 2007). Em um segundo experimento, o momento da aplicação da hCG foi mais tardio, já no dia 25 dos animais gestantes. A taxa de perda embrionária foi significativamente reduzida comparada com os animais controle (CAMPANILE et al., 2008). Da mesma forma, Pandey et al. (2013) encontraram melhor perfil luteal, concentração plasmática de progesterona e taxa de prenhez comparado com o grupo controle.

Além destes efeitos já bem estudados e conhecidos, um paradigma deve ser mudado, de que LH e hCG são hormônios reguladores de gônadas somente (RAO, 2001). Evidências demonstraram que existem receptores de LH/hCG extragonadais, sugerindo possíveis outras ações destes hormônios (FILICORI et al., 2005).

Tecidos não gonadais possuem menor quantidade de receptores comparados com os gonadais entretanto em humanos, a ocupação de menos de 10\% dos receptores induz máxima resposta biológica das gônadas. Portanto os menores níveis destes receptores em outros tecidos podem ser funcionalmente equivalentes. Em suínos, foi demonstrada a presença de receptores de hCG/LH no miométrio e endométrio (ZIECIK; STANCHEV; TILTON, 1986), assim como no útero em humanos (RESHEF et al., 1990).

Em humanos, a ativação do receptor causou maior expressão de COX-2, estimulou a diferenciação de células estromais, modulou as citocinas pró e anti implantacionais, aumentou o fluxo sanguíneo por vasodilatação e angiogênese e inibiu contrações miometriais (RAO, 2001; ZIECIK et al., 2007). Ainda em humanos, na ampola do oviduto, a ativação do receptor resultou no aumento da COX-2, aumentou PGE 2 e síntese de glicoproteínas que promovem maturação dos gametas, fertilização, crescimento do embrião e desenvolvimento e transporte no momento adequado do embrião para o útero (RAO, 2001).

Além disso, a hCG parece afetar a espessura do endométrio e receptividade uterina independente da função ovariana (FILICORI et al., 2005). Em mulheres, a aplicação de hCG para induzir a ovulação provoca um incremento de fluxo sanguíneo 
uterino (TOTH et al., 1994; WASEDA et al., 2003), além de facilitar o primeiro passo na angiogênese que é o aumento da permeabilidade vascular (NEULEN et al., 1995). Também promoveu o relaxamento da musculatura lisa e vasodilatação miometrial (KEAY et al., 2004).

A administração da hCG para porcas na fase luteal mostrou que ela pode diretamente afetar o fluxo sanguíneo uterino (ZIECIK et al., 1986). E em ratos, in vivo, a hCG dilatou as artérias uterina e mesentérica (HOYER; NISWENDER, 1985) e provocou vasodilatação nas artérias uterinas de ratas prenhes ou não gestantes (HERMESTEINER et al., 1999), além da vasculatura uterina em humanos (JAUNIAUX et al., 1992).

In vitro, células da microvasculatura uterina endotelial responderam a doses de hCG com aumento da formação de capilares, mas não as células da macrovascularização, talvez pela ativação da proteína quinase C (ZYGMUNT et al., 2002), que possui um importante papel na formação de capilares e fase de sobrevivência da angiogênese (DAVIS et al., 1993; XIA et al., 1996; ILAN et al., 1998). A hCG também pareceu regular a expressão do gene de VEGF no ovário e em macrófagos (NEULEN et al., 1995; ZYGMUNT et al., 2002), indicando a importância da hCG como um fator vasculo-angiogênico (FILICORI et al., 2005)

Baseado nos trabalhos encontrados na literatura, ainda existe dúvida com relação aos efeitos sobre o CL e fertilidade do tratamento com hCG nas diferentes espécies e novas pesquisas para conhecer melhor os efeitos extragonadais ainda devem ser realizadas.

\subsubsection{Utilização da hCG em Equinos}

Em equinos a hCG vêm sendo utilizada há mais de 70 anos para induzir ovulação (NEWCOMBE, 2011), sendo uma das drogas mais importantes na manipulação farmacológica do ciclo estral da égua. Entretanto sua aplicação no diestro com o intuito de melhorar a capacidade esteroidogênica do CL é uma abordagem recente, que ainda requer pesquisas (FLEURY, 2004). Nos tópicos seguintes estes dois aspectos serão discutidos. 
2.5.4.1 Adiantamento de ovulação

A determinação do momento ideal para inseminar uma égua se torna difícil devido ao estro longo, por isso alguns artifícios são utilizados (MCCUE et al., 2004). A hCG foi a primeira droga utilizada para causar ovulação em éguas, já em 1939 (DAY,5 1939 apud MCKINNON; MCCUE, 2011, p. 1858). A hCG em equinos é geralmente utilizada para programar a ovulação em um específico intervalo de tempo (MCKINNON; MCCUE, 2011). Esta programação é utilizada nos casos em que a IA com sêmen refrigerado e congelado é necessária, com o intuito de reduzir os custos e facilitar o manejo do animal; utilizar sêmen de garanhões com alta demanda; reduzir o intervalo entre múltiplas ovulações assincrônicas (NEWCOMBE, 2011), garantir apenas uma IA para éguas com endometrite pós cobertura, sincronizar doadora e receptora em programas de TE (BRADECAMP, 2011), permitir a aspiração folicular para recuperação de oócito para técnicas assistidas de reprodução (GINTHER, 1992; CARNEVALE, 2011), entre outros.

Alguns autores acreditam que o termo indução de ovulação seria incorreto no contexto da ovulação porque na maioria dos casos, o folículo iria ovular nos próximos 2 a 4 dias espontaneamente. Portanto os agentes chamados de indutores de ovulação causam na verdade um adiantamento da ovulação (NEWCOMBE, 2007).

Pré requisito para uma boa resposta à aplicação destes agentes é que a égua esteja em estro, com folículos pré ovulatórios de 32 a 35 mm ou mais (GINTHER, 1992; CARNEVALE, 2004), apresentar sinais de cio, relaxamento cervical e edema endometrial (GREEN et al., 2007; MCKINNON; MCCUE, 2011). Algumas raças (como Shire) e éguas individuais ovulam folículos maiores e por isso o tratamento quando o diâmetro for de 32 a 35 mm pode não ser eficiente, devido a uma maturação insuficiente (SAMPER, 2001).

\footnotetext{
${ }^{5}$ DAY, F.T. Ovulation and descent of the ovum in the fallopian tube of the mare after treatment with gonadotrophic hormones. The Journal of Agricultural Science, v.29, p. 459-469, 1939.
} 
A utilização da hCG em geral garante que a ovulação irá ocorrer em um intervalo aproximado de 36 às 48h (GINTHER, 1992; MCCUE et al., 2004; EVANS et al., 2006; NEWCOMBE, 2007; SQUIRES, 2008).

Comercialmente está disponível como uma preparação congelada e liofilizada em frascos de 5000 a 10000 unidades internacionais (UI), com um solvente. As utilizações intravenosa, intramuscular e subcutânea são eficazes. A dose é empírica e varia de 1000 a 5000UI. De acordo com Newcombe (2007), nenhuma das vias apresenta vantagens sobre as demais. Muitos veterinários usam 1500UI apesar de 750UI poderem ser tão efetivas quanto outras doses (NEWCOMBE, 2007; DAVIES MOREL; NEWCOMBE, 2008; NEWCOMBE, 2011).

Vários trabalhos demonstraram a eficiência da hCG em programar a ovulação dentro do intervalo esperado, tornando esta uma ferramenta fundamental no manejo reprodutivo de equinos (BARBACINI et al., 2000; BLANCHARD; BRINSKO; RIGBY, 2002).

Entretanto alguns pontos negativos foram percebidos, como uma importante influência da idade, com uma diminuição da resposta com o seu avanço. Os dados obtidos por este grupo foram que das éguas com menos de 6 anos, 8\% não responderam; entre 6 e 10 anos, 14\%; entre 11 e 15 anos, 18\%; entre 16-20 anos, 21\% e mais que 20 anos, 26\% (MCCUE et al., 2004).

Outro ponto a ser avaliado é uma possível relação da sua utilização com maior perda embrionária e menores taxas de nascimento, como foi notado em éguas PSI (ZUÑIGA, 2005).

Urquieta et al. (2009) encontraram CLs menores a partir de folículos pré ovulatórios menores durante os primeiros dias pós ovulação, assim como foi encontrado por Bergfelt (2000) que indicaram que o CL tem um tamanho 65-80\% do folículo pré ovulatório. Isto pode explicar o menor tamanho dos CLs entre 1 e 3 dias pós ovulação nas éguas tratadas com hCG, e que talvez o CL pequeno e insuficiente pudesse afetar a manutenção da gestação. A taxa de prenhez no primeiro ciclo neste experimento no grupo tratado com hCG foi numericamente diferente do grupo controle, sendo $57 \%$ e $83,3 \%$ respectivamente $(12 / 21$ e 10/12). Os pesquisadores sugerem que, apesar de não haver diferença estatística pelo número pequeno de animais, um efeito negativo da hCG na fertilidade em éguas pode ocorrer. A justificativa para este decréscimo na taxa de prenhez foi o menor diâmetro folicular, o que poderia refletir em uma insuficiente maturação oocitária. Entretanto essa diminuição não poderia ser atribuída à 
insuficiência luteal primária, pois os CLs dos grupos tiveram desenvolvimento e função normais quando avaliados por ultrassonografia e mensuração de progesterona plasmática. Eles propuseram que talvez estes efeitos tenham relação com a indução da ovulação de folículos antes do tamanho ovulatório (URQUIETA et al., 2009).

\subsubsection{2 hCG no diestro}

As primeiras publicações a respeito da aplicação de hCG no diestro datam de meados dos anos 70. Allen (1983) encontrou que a aplicação da hCG no final do diestro e início da gestação provocaram luteólise e consequente perda embrionária. A hipótese por eles aventada foi de uma provável estimulação da produção da $\mathrm{PGF}_{2 a}$ endometrial pelo LH.

Mais tarde, Kelly et al. (1988) testaram os efeitos da hCG in vitro e in vivo e mostraram que o tratamento com 1000UI hCG nos dias 3, 4 e 5 após o estro resultaram em aumento de progesterona do dia 7 ao dia 14 em éguas e também um aumento da produção in vitro de progesterona com a adição de hCG às células luteais. A explicação para este efeito encontrado foi uma possível alteração na composição das células luteais ou aumento do número de células produtoras de progesterona. Michel et al. (1986) detectaram um aumento nas concentrações de progesterona mais cedo nos animais que receberam hCG comparando-se com GnRH ou salina.

Com o raciocínio de que substâncias luteotróficas poderiam ser alternativa para provocar um aumento nas concentrações de progesterona e tendo os resultados prévios positivos acima citados como ponto de partida, Paccamonti et al. (1991) aplicaram 1000UI de hCG IM em éguas nos dias 0, 1 e 2 pós ovulação e avaliaram as concentrações circulantes de progesterona até o retorno ao estro ou até dia 25 pós ovulação. Eles encontraram concentrações menores no dia 7 no grupo tratado com hCG do que no grupo controle. A ideia dos autores seria de um resgate com o uso da hCG de um CL cuja formação e função tenham sido afetadas entretanto os resultados encontrados não confirmaram a hipótese proposta. Eles propuseram que o CL pudesse não estar responsivo ao hCG no período logo após a ovulação, uma saturação dos receptores de LH 
com o LH endógeno, tornando-os incapazes de responder à aplicação de hCG, baixo número de receptores de LH ou baixa afinidade dos receptores. Com isso, eles sugerem que a suplementação com progesterona possa ser preferível, uma vez que não depende da capacidade de resposta ao hCG ou não.

Baseando-se no princípio dos trabalhos realizados com bovinos e outras espécies no qual um efeito benéfico da hCG na formação de CLs acessórios, nas concentrações plasmáticas de progesterona, e nas taxas de prenhez foi notado, Fleury et al. (2007) utilizaram a hCG em éguas. No estudo, a hCG foi aplicada no dia da TE e as taxas de prenhez foram numericamente diferentes $(25,7 \%$ mais altas no dia 16$)$ comparadas com as do grupo controle. Os autores propuseram que houve um efeito luteotrófico uma vez que as concentrações de progesterona foram maiores no grupo tratado com hCG apesar de não terem sido formados corpos lúteos acessórios.

Seguindo a linha de pesquisa iniciada, Souza (2006) aplicaram hCG em éguas para induzir a ovulação ou no dia 1 pós ovulação e mensuraram as concentrações plasmáticas de progesterona e avaliaram as características uterinas e cervicais no dia 6 pós ovulação. Uma maior concentração de progesterona foi encontrada nos dois grupos tratados com hCG no dia 4 pós ovulação, mostrando um aumento mais precoce nos níveis de progesterona. A porcentagem das éguas tratadas com hCG que apresentaram características uterinas e cervicais consideradas adequadas para a utilização como receptoras de embrião no dia 6 pós ovulação foi estatisticamente maior do que o controle. Os resultados foram $57,1 \%$ das éguas no grupo controle apresentavam características adequadas para TE, comparado com 89,3\% do grupo que recebeu hCG no dia 1 e 78,57\% do grupo que recebeu hCG para induzir a ovulação.

Fundamentado nestes resultados encorajadores da utilização da hCG acima descritos, Hartman (2011) utiliza 3000UI por via intramuscular no dia da TE em seu programa comercial no Texas, em associação com aplicação de flunixin meglumine e antibioticoterapia.

Hendriks, Colenbrander e Stout (2006) não encontraram efeito da aplicação da hCG no dia 7 pós ovulação no fluxo sanguíneo uterino e ovariano e nas concentrações de progesterona. Os autores concluíram que não houve efeito luteotrófico e nem luteolítico da hCG aplicada neste momento do diestro.

Um trabalho recente realizado pelo grupo de McCue et al. (2012) aplicou hCG, deslorelina ou solução salina no momento da transferência do embrião em alguns 
programas comerciais de TE. Os resultados encontrados mostraram que não houve efeito positivo traduzido em incremento da taxa de gestação com a aplicação da deslorelina, entretanto a hCG reduziu significantemente a taxa de prenhez $(88,5 \%$ placebo; $86,9 \%$ deslorelina e $72,1 \%$ hCG), contrariando os resultados encontrados por Fleury et al. (2007).

Um número pequeno de trabalhos utilizando a hCG no diestro foi realizado com éguas comparado com o grande número de trabalhos publicados com bovinos. Pode-se notar com os resultados apresentados dos trabalhos que até hoje muito pouco se conhece sobre os efeitos e mecanismos de ação da hCG em éguas, e ainda há muitas perguntas para serem respondidas.

Vale a pena relatar alguns trabalhos realizados utilizando análogos do GnRH objetivando os mesmos efeitos citados da hCG em éguas, com o intuito de instigar um questionamento e trazer ideias a respeito dos resultados divergentes encontrados e propor possíveis respostas para as dúvidas encontradas com a utilização da hCG.

Newcombe, Martinez e Peters (2001) utilizou um protocolo que consistia na aplicação de 20-40mg de buserelina entre os dias 8 e 12 pós ovulação. Foram tratados neste estudo 2346 éguas e um aumento de aproximadamente $10 \%$ na taxa de prenhez foi detectado. Os autores reforçam a ideia de que 10\% de aumento na taxa de prenhez é importante na questão de eficiência reprodutiva, sendo este valor extremamente significativo.

Outro grupo testou a aplicação de buserelina no dia 10 em 191 éguas e avaliou as concentrações de LH e progesterona, além das taxas de gestação. Encontraram um aumento nos níveis de LH, entretanto a concentração de progesterona não se mostrou diferente. Além disso, as taxas de prenhez foram 10\% maiores no grupo tratado, porém não houve diferença estatística (KANITZ et al., 2007). 0 mecanismo pelo qual o GnRH aumenta as taxas de prenhez é ainda desconhecido, uma vez que a progesterona aparentemente não se modifica, porém ele pode ter também um efeito luteotrófico indireto, por estimular a secreção endógena do LH (PYCOCK; NEWCOMBE, 1996). 


\subsubsection{Formação de Anticorpos}

Como a hCG possui um alto peso molecular e é uma glicoproteína, anticorpos podem ser formados após repetidos tratamentos (ROSER et al., 1979; WILSON et al., 1990; SAMPER, 2008). Não existe mais a dúvida quanto à formação dos anticorpos com a frequente utilização da hCG, a questão atual centraliza-se no efeito das aplicações da hCG e da formação de anticorpos sobre a confiabilidade da indução de ovulação. Isto se deve aos resultados conflitantes encontrados na literatura, com alguns estudos apontando para uma perda na eficácia da hCG após a aplicação em vários ciclos (WILSON et al., 1990; MCCUE et al., 2004; GREEN et al., 2007; SAMPER, 2008; NEWCOMBE, 2011) enquanto outros relatam não haver refratariedade após tratamentos repetidos (BARBACINI et al., 2000; GASTAL et al., 2006).

Sullivam et al. (1973) realizaram um experimento com 15 éguas no qual os animais foram tratados com hCG por ciclos 3 estrais consecutivos e observou-se um atraso de 1 a 2 dias no $3^{\circ}$ ciclo.

Durante os meses de março a outubro, 12 éguas foram consecutivamente todos os ciclos com hCG. Destas, 5 apresentaram níveis de anticorpos significantes após 2 a 5 aplicações. A meia vida dos anticorpos variou de 1 a vários meses. entretanto, sua produção não provocou refratariedade ovulatória pela ausência de reação cruzada com o LH endógeno (ROSER et al., 1979; NEWCOMBE, 2011).

Blanchard et al. (2003) não detectaram alteração na eficiência da hCG em éguas que receberam ate 4 aplicações na mesma estação de monta. Wilson et al. (1990) encontraram anticorpos mas não houve efeito sobre o tempo para a ovulação até o 5ํㅗ tratamento. No ano seguinte, as mesmas éguas tiveram até o $6^{0}$ tratamento $53 \mathrm{~h}$ para a ovulação, 62h após o 7ํㅜ 88 horas para as éguas com 10 tratamentos. Baseado nos experimentos realizados, uma resposta variável com relação aos anticorpos foi encontrada e altos títulos de anticorpos não foram correlacionados com intervalo maior para a ovulação.

Green et al. (2007) avaliando 580 éguas encontraram que 80\% ovularam em 48 horas quando feitos ate 2 tratamentos, mas apenas $58 \%(n=109)$ após o $3^{\circ}$. Animais com 6 a 8 tratamentos ovularam $67 \%$ das vezes $(n=18)$. 
Newcombe e Wilson (2007) avaliaram retrospectivamente animais que foram tratados com 2500UI de hCG por 7 estações de monta consecutivas. Os dados mostraram que dos animais que receberam tratamento de 5 a 8 vezes, 83,5\% ovularam no intervalo esperado e daqueles que receberam 9 a 16 tratamentos ovularam 83,2\%. Não houve diferença entre os dois grupos. Um animal recebeu 16 tratamentos durante as 7 estações consecutivas e ovulou dentro do período esperado em $100 \%$ das vezes. Contrariamente, McCue et al. (2004) notaram um decréscimo na resposta à hCG já a partir do $2^{\text {o }}$ ciclo tratado.

De acordo com Siddiqui et al. (2009), 42\% dos animais expostos previamente apresentou anticorpos para hCG. Algumas éguas (34\%) mesmo apresentando anticorpos, responderam ao tratamento com hCG e ovularam dentro de 48h. Os anticorpos foram eficientes na neutralização da hCG, uma vez que em 16 éguas não foi detectada hCG 30h após o tratamento. De acordo com um trabalho recente, apenas em $42 \%$ dos casos o efeito variável da hCG pode ser atribuído à presença de anticorpos. As éguas com anticorpos tinham folículos com menor porcentagem de fluxo sanguíneo na parede comparado com o grupo negativo. Além disso, apenas 1 oócito dos animais do grupo com alto nível de anticorpos para hCG havia sofrido maturação no momento da coleta, podendo este inclusive já se apresentar maduro porque poderia estar próximo da ovulação independente da aplicação da hCG. Mas este baixo número de oócitos maduros indica uma eficácia muito baixa de ação da hCG na presença de seus anticorpos (SIDDIQUI et al., 2009).

Com base no acima citado, deve-se ter conhecimento de que a aplicação de hCG causa a formação de anticorpos em alguns indivíduos e que eles podem afetar a resposta esperada ao tratamento.

\subsection{ULTRASSONOGRAFIA DOPPLER}

A seguir serão abordados os princípios, conceitos da ultrassonografia Doppler, além dos estudos que vêem sendo realizados em equinos. 


\subsection{Princípios e Conceitos}

Ultrassom é definido como qualquer frequência de som acima da capacidade auditiva, ou seja, $20000 \mathrm{~Hz}$. As ondas sonoras são produzidas pela vibração de cristais piezoelétricos do transdutor, sendo as vibrações causadas por pulsos elétricos. Uma parte das ondas volta ao transdutor com a frequência alterada de acordo com a estrutura que encontrou e é convertida para corrente elétrica e aparece como eco na tela do ultrassom. 0 transdutor envia e recebe os ecos que são mostrados como variações de cinza na tela (RANTANEN; EWING, 1981; PYCOCK, 2011). A primeira utilização em veterinária foi em 1966 para detectar a gestação em ovelhas (LINDHAL, ${ }^{6} 1966$ apud MEDAN; ABD EL-ATY, 2010, p. 123).

Em ultrassonografia Doppler o transdutor é o objeto estacionário e as hemácias são os refletores em movimento que retornaram os ecos emitidos. Quando um raio de ultrassom (US) encontra um objeto em movimento tal ocorre com a hemácia no fluxo vascular, a frequência do eco é alterada. A frequência Doppler será a diferença entre a frequência do eco recebido para a frequência das ondas transmitidas. A frequência aumenta quando o objeto se aproxima da probe, sendo então o shift Doppler positivo. 0 contrário, quando o objeto se afasta da probe, a frequência diminui, sendo o shift Doppler negativo. A medida das alterações do eco retornado permite que a direção e velocidade do fluxo sejam determinados (GINTHER, 2007; MEDAN; ABD EL-ATY, 2010).

0 ângulo com o qual as ondas de ultrassom intersectam ou impactam o caminho do fluxo sanguíneo é chamado de ângulo Doppler ou ângulo de insonação. As velocidades sanguíneas são diretamente proporcionais ao valor da frequência do Shift Doppler e indiretamente proporcional ao cosseno do ângulo Doppler.

Dois tipos de modo Doppler na reprodução são utilizados, o ColorFlow e o espectral pulsado. No modo espectral pulsado, o fluxo sanguíneo em um vaso específico é avaliado colocando-se um cursor na imagem em modo B ou no modo, no lúmen do vaso para representar o ângulo de insonação dos raios. Um gráfico espectral se forma que representa a mudança de velocidades ao longo do tempo, sendo representativo do ciclo cardíaco. Mensuram-se as velocidades no pico sistólico (PSV), final diastólico (EDV) e média das velocidades máximas durante o ciclo cardíaco (TAMV) ao longo de cada

${ }^{6}$ LINDHAL, I.L. Detection of pregnancy in sheep by means of ultrasound. Nature, v. 212, p.642-643, 1966. 
ciclo cardíaco mostrado. A PSV representa o ponto máximo no gráfico que representa também o maior shift Doppler. Similarmente, o máximo valor no ponto mais baixo antes do próximo aumento sistólico é o EDV ou velocidade diastólica final. TAMV é a média das velocidades máximas ao longo do ciclo (parte superior do gráfico). Além destes, os índices Doppler de pulsatilidade (PI) e resistividade (RI) são razões das velocidades que indicam aumento ou diminuição de resistência vascular distal ao ponto de mensuração. RI é PSV menos EDV sobre PSV e PI é PSV-EDV sobre TAMV. Portanto, RI e PI independem do ângulo de insonação e são úteis quando o vaso é tortuoso para acomodar um cursor de ângulo. RI é mais utilizado por facilitar o raciocínio, sendo que uma menor resistência indica maior facilidade de fluxo para a determinada estrutura. Alto PI indica diminuída perfusão para o órgão distal ao ponto de mensuração. Existe uma alta correlação entre PI e RI, sendo que somente se faz necessária a utilização de uma delas. Situações específicas podem determinar uma indicação para utilização de um dos dois índices. PI deve ser usada nos casos em que o fluxo é ausente ou praticamente ausente durante a diástole. Já o RI é mais indicado nos casos em que ocorre um fluxo vascular contínuo durante a diástole. Os aspectos negativos deste modo são a restrição da área de análise para apenas uma pequena porção e a dificuldade em obter um espectro bom. Os movimentos do animal e da víscera tornam mais difícil a técnica (GINTHER; UTT, 2004; GINTHER, 2007).

A avaliação da imagem Color Flow pode ser feita de forma objetiva ou subjetiva. Uma imagem com vascularização máxima é escolhida e os pixels coloridos contados por programas de computador, fornecendo uma medida quantitativa da perfusão. Uma desvantagem é trabalhar com imagens únicas e não fazer avaliação em tempo real. Uma vez que a determinação da imagem a ser mensurada é feita pelo avaliador, pode haver influência neste momento (GINTHER, 2007).

O outro modo de avaliação é a subjetiva no qual escores de avaliação são dados para a vascularização mínima (1) à máxima (4). Este método facilita a identificação do perfil e a análise estatística durante um período e entre os grupos experimentais. 0 ponto negativo é a subjetividade do avaliador, entretanto pode-se torná-la objetiva gravando as imagens para posterior análise sem conhecimento do tratamento e do momento do ciclo ou por um segundo operador que desconheça as informações daquela imagem. Essa avaliação por Color tem grande utilidade clínica e em pesquisa, pois foca 
no tecido ou estrutura de interesse e pode ser realizada rapidamente em tempo real (GINTHER, 2007; FERREIRA; MEIRA, 2011).

No modo Color, pontos coloridos nas imagens bidimensionais representam áreas de fluxo sanguíneo, permitindo a avaliação subjetiva da extensão da perfusão vascular de uma estrutura durante o escaneamento em tempo real. Uma avaliação objetiva utilizando a mensuração de pixels coloridos pode ser feita em uma determinada imagem selecionada (GINTHER; UTT, 2004).

Entretanto, movimentos do animal, da parede abdominal, órgãos e transdutor podem fazer com que a manutenção dos cursores espectrais no local do vaso escolhido ou na avaliação Color sejam difíceis, provocando artefatos (GINTHER, 2007).

Quando é sabido o ângulo de insonação, o diâmetro do vaso e a velocidade média do fluxo, pode-se calcular o volume de fluxo sanguíneo em $\mathrm{mL} / \mathrm{min}$. Entretanto essa mensuração é muito difícil de ser realizada nos vasos do trato reprodutivo (SILVA, 2009).

\subsubsection{Doppler na Reprodução em Equinos}

A aplicação da ultrassonografia em tempo real no estudo da reprodução em animais representa um avanço que revoluciona o conhecimento da biologia reprodutiva. As informações geradas ajudam a esclarecer diversos processos reprodutivos complexos como a dinâmica folicular, função luteal e desenvolvimento embrionário e fetal (SILVA, 2009; MEDAN; ABD EL-ATY, 2010). Os primeiros estudos com US modo B em equinos foram feitos por Palmer e Driancourt (1980), quando uma série de estudos caracterizando os folículos, CL, útero ao longo do ciclo estral começaram a ser feitos.

As tecnologias disponíveis na atualidade com relação à ultrassonografia, modo $\mathrm{B}$ e Color Doppler têm grande valor para a pesquisa, diagnóstico e prognóstico em reprodução equina, podendo ser utilizados separados ou em conjunto (BERGFELT; ADAMS, 2011).

A ultrassonografia Doppler Colorido vem sendo utilizada e tem causado grande impacto na medicina humana por mais de duas décadas, diferente do que ocorre em 
reprodução e em pesquisa animal na qual ainda está em seu início. Ela associa a informação sobre fluxo sanguíneo à imagem do modo B em anatomia e função. (GINTHER; UTT, 2004). Em 1998, McKinnon demonstrou a possibilidade de sua utilização na avaliação do ovário e gestação. A tecnologia tem avançado e aparelhos portáteis associando o modo B e o modo Color Doppler têm sido desenvolvidos, o que permite de uma forma mais completa a avaliação estrutural e funcional do corpo lúteo ao longo do ciclo estral e início da gestação (GINTHER, 1992; GINTHER, 2007).

$\mathrm{Na}$ década de 90, alguns estudos foram publicados utilizando Doppler na reprodução em equinos. Na década passada, ainda existia uma concentração destes experimentos a alguns grupos, e o foco básico era a fisiologia reprodutiva básica. 0 atual cenário encontrado é uma grande quantidade de laboratórios utilizando a ultrassonografia Doppler, ainda com enfoque em fisiologia, mas já apresentando uma visão aplicada (SILVA et al., 2006; SILVA, 2009).

Ela poderia auxiliar em diversas situações encontradas diariamente pelo clinico, como decidir se um folículo na época de transição vai ovular ou não, determinar a proximidade da ovulação, avaliar o status funcional do CL, avaliar a possibilidade de perda embrionária, avaliar a vasculatura de um folículo pré ovulatório e prever a qualidade oocitária, avaliar a qualidade do endométrio para TE e detecção de fluxo sanguíneo alterado (GINTHER, 2007; GINTHER et al., 2007a).

A ultrassonografia Doppler transretal começou a ser utilizada para investigar mecanismos reprodutivos em éguas por Bollwein et al. (2002), Acosta et al. (2004), Silva et al. (2006) e Ferreira, Gastal e Ginther (2008). Antigamente, mudanças no corpo lúteo durante o ciclo estral em éguas só poderiam ser monitoradas usando a ultrassonografia modo B (GINTHER, 1992) ou por meio da mensuração dos níveis de progesterona circulantes (MCCUE et al., 1999; ARRUDA et al., 2001). Atualmente o fluxo sanguíneo pode ser visualizado e analisado, correlacionando-o com os outros aspectos.

A avaliação do fluxo sanguíneo uterino e do corpo lúteo durante o ciclo estral da égua após a aplicação de hCG ainda não foi realizada e poderá trazer novas informações a respeito dos mecanismos de ação da hCG para aumentar a produção de progesterona pelo corpo lúteo e melhorar as taxas de prenhez. 


\subsubsection{Ovário}

Mudanças hemodinâmicas estão envolvidas no remodelamento cíclico do tecido ovariano que ocorre durante o crescimento folicular, ovulação e formação e regressão do CL (ACOSTA et al., 2004). A ultrassonografia Doppler é uma poderosa ferramenta para avaliar a função vascular ovariana, permitindo a observação do fluxo sanguíneo em uma área do folículo pré ovulatório (GASTAL; GASTAL; GINTHER, 2006), ou no CL (BOLLWEIN et al., 2002, 2003).

Nos ovários acontece uma série dos principais eventos reprodutivos na égua e por eles são produzidos o estrógeno e a progesterona, responsáveis pelas mudanças no trato reprodutivo ao longo do ciclo estral. Com isto, entende-se o motivo pelo qual tanta atenção é direcionada para eles nos estudos com US Doppler. Avaliações espectrais e com Color Flow são possíveis, sendo folículos, CL, vasos do CL e pedículo ovariano as estruturas a serem avaliadas (GINTHER, 2007).

Uma intensa angiogênese ocorre no CL durante o ciclo estral (HANSEL; BLAIR, 1996), sendo ela fundamental tanto para a biossíntese da progesterona como para a secreção de outros hormônios esteroides pelas células luteais (CARR et al., 1982). Desta forma, pode-se supor que a circulação sanguínea seja vital para uma função adequada do CL (BOLLWEIN et al., 2002). Neste primeiro estudo, curiosamente o fluxo sanguíneo luteal diminuiu no meio do diestro, antecipando em alguns dias a queda plasmática da progesterona. Em mulheres, este mesmo declínio da progesterona no meio do diestro também é descrito (BOLLWEIN et al., 2002).

Apesar de fornecer vários dados sobre as velocidades e padrões do fluxo sanguíneo em éguas, a artéria ovariana não permite a colocação de um cursor com correção de ângulos para a mensuração das velocidades absolutas, tornando apenas as medidas de PI e RI úteis na sua avaliação (GINTHER; UTT, 2004).

No folículo, existem duas camadas vasculares, a teca externa composta de arteríolas e vênulas e a teca interna com uma grande rede capilar, o que possibilita uma avaliação com Doppler. Os eventos do desenvolvimento folicular vêm sendo estudados (ACOSTA et al., 2004; ACOSTA; BEG; GINTHER, 2004), apresentando um potencial de aplicabilidade clínica. Um exemplo é a possibilidade de prever se um folículo durante a fase de transição será ou não ovulatório baseado no seu fluxo sanguíneo, de acordo com 
achados de que o fluxo nos folículos anovulatórios é menor comparado com os folículos ovulatórios (ACOSTA; BEG; GINTHER, 2004).

Acosta et al. (2004) avaliaram o fluxo sanguíneo dos folículos pertencentes a uma onda folicular e conseguiram notar que o desvio do diâmetro entre os dois maiores folículos era antecedido por uma alteração de fluxo sanguíneo em 1 (área de fluxo sanguíneo) a 2 dias (velocidades de fluxo sanguíneo).

Outro achado interessante estudando o folículo pré ovulatório foi uma diminuição de fluxo sanguíneo nas 4 horas que antecedem a ovulação e mais especificamente na região apical (área onde ocorrerá a ruptura folicular) (GASTAL; GASTAL; GINTHER, 2006), podendo facilitar o manejo reprodutivo, em especial com a utilização do sêmen congelado, por exemplo.

Em trabalho realizado por Gastal et al. (2006), os efeitos da hCG sobre os sinais Doppler coloridos e ecotextura foram avaliados. No grupo tratado com hCG, um aumento na espessura da granulosa e ecogenicidade e um decréscimo no estradiol durante as 36 horas após o tratamento foi observado comparado com o controle.

A extensão da vascularização da parede do folículo pré-ovulatório detectada foi positivamente associada com a taxa de prenhez em humanos (BHAL et al., 2001). Em equinos, houve uma associação entre aumento no fluxo sanguíneo ao folículo pré ovulatório na hora 0 (hCG) e diminuição no índice de resistência e pulsatilidade e aumento nos sinais de Doppler na parede folicular com taxa de prenhez. As éguas que comparativamente tiveram maior vascularização se tornaram gestantes e as com menor vascularização ficaram vazias (SILVA et al., 2006).

Na US humana, o fluxo sanguíneo do corpo lúteo vem sendo estudado há vários anos (ZALUD; KURJAK, 1990; BOURNE et al., 1996). Nestes estudos, não só foram notadas diferenças ao longo do ciclo, mas também variações individuais na circulação do CL (GLOCK; BRUMSTED, 1995). Estes achados trouxeram à tona a discussão sobre uma possível relação entre uma perfusão sanguínea luteal insuficiente e uma falha na fase luteal em mulheres (TINKANEN, 1994).

Bollwein et al. (2002) foram os primeiros a realizar um estudo com o objetivo de correlacionar a área do CL, a perfusão sanguínea luteal e a produção plasmática de progesterona. Foi notado um aumento da circulação luteal dos dias 0, 1 e 2 até o dia 5 . Entre os dias 5 a 7 ela se manteve constante e diminui a partir de então até o dia 15. Além disso, houve uma relação paralela do aumento do número de pixels no CL com a 
concentração plasmática de progesterona. No dia 7 foram encontrados os maiores valores de concentração plasmática de progesterona, sendo que a vascularização máxima antecedeu em 2 dias, ocorrendo no d5, ou seja, uma queda na circulação luteal antecedeu a queda de progesterona circulante. A área do CL foi máxima no dia 2 pós ovulação e a partir de então diminui até o dia 15. Diferenças de fluxo sanguíneo individuais também foram notadas enquanto entre ciclos não foi notada diferença. A área do CL variou individualmente, mas independente do estágio e do número do ciclo (1ำ ou $2^{\underline{o}}$ ). A concentração de progesterona foi diferente ao longo dos dias do ciclo, entretanto não houve diferença individual e entre ciclos do mesmo animal. Detectou-se alta correlação entre fluxo sanguíneo do CL e concentração de progesterona plasmática (BOLLWEIN et al., 2002).

Bourne et al. (1996) relacionaram a queda de fluxo sanguíneo luteal com o início da inervação vegetativa do CL. Essa inervação pode permitir que a $\mathrm{PGF}_{2 \ltimes}$ afete os vasos do CL no momento da luteólise (HAMBERGER, 1980). Nos primeiros dias do ciclo, os vasos sanguíneos do CL são desprovidos de células musculares e inervação, tornando-os maximamente dilatados sem possibilidade de regulação de fluxo sanguíneo luteal, sendo apenas dependente da pressão sanguínea (BOURNE et al., 1996).

Apesar de fornecer importante informação sobre o fluxo sanguíneo no CL, não se pode determinar a concentração plasmática de progesterona pela ultrassonografia Doppler (BOLLWEIN et al., 2002).

Independente da concentração da progesterona, mulheres cujos CLs apresentavam menor fluxo sanguíneo apresentaram menor chance de se tornarem gestantes (BABER et al., 1988).

Ainda estudando a vascularização do CL, Ginther et al. (2007) também encontraram um aumento da vascularização durante o desenvolvimento do CL até o dia 6, corroborando com o estudo descrito anteriormente. No dia 8 foi encontrado o fluxo sanguíneo do CL máximo. Uma importante conclusão deste grupo foi a semelhança de resultados de fluxo sanguíneo entre os grupos apesar da diferença nos parâmetros mensurados. O experimento de Bollwein et al. (2002) utilizou a contagem de pixels coloridos da imagem, enquanto este grupo utilizou a atribuição de porcentagem de vascularização do CL, que é uma técnica mais facilmente aplicável a campo. 
Outro aspecto importante encontrado foi que éguas gestantes e não gestantes no dia 7 pós ovulação não apresentaram diferenças vascularização do CL e nos índices PI e RI (SILVA et al., 2006).

Araújo et al. (2009) avaliaram a perfusão vascular do trato reprodutivo de éguas e perceberam que RI e PI eram menores no pedículo ovariano ipsilateral ao CL, indicando uma maior perfusão sanguíneo para o ovário contendo o $\mathrm{CL}$, assim como foi observado em mulheres (MIYAZAKI et al., 1998). Baseado em estudos com fluxo sanguíneo, o CL tem consideravelmente mais fluxo por unidade de tecido que outros órgãos. Em coelhos, a resistência vascular no estroma ovariano é 10 vezes maior do que no CL (WILTBANK et al., 1990).

Além do desenvolvimento do CL, o evento da luteólise também foi avaliado. Os resultados encontrados mostraram uma importante diferença entre a luteólise em equinos e bovinos. Em vacas, um aumento de fluxo no CL antecipa a lise, o que não foi confirmado em éguas. Apenas $24 \mathrm{~h}$ após a aplicação da $\mathrm{PGF}_{2 \alpha}$ ocorreu uma diminuição de fluxo e a queda de progesterona circulante começou antes do que qualquer mudança no fluxo sanguíneo pudesse ser notada (GINTHER et al., , 2007).

A última estrutura estudada no ovário que ainda não foi discutida são os folículos persistentes anovulatórios (FPA). Encontraram no dia anterior a não ovulação um fluxo sanguíneo folicular maior nos FPAs do que nos folículos que ovularam subsequentemente. Entretanto alguns indivíduos que ovularam apresentaram grande quantidade de vascularização, tornando difícil determinar apenas por essa avaliação, o destino do folículo (GINTHER et al., 2006). A presença de pontos de vascularização no ápice do folículo parece estar associada com falha de ovulação ou evacuação septada do folículo (GINTHER, 2007). A vascularização do FPA após sua formação parece a de um CL normal, eventualmente apresentando uma artéria em banda hiperecogênica no meio da estrutura, possivelmente por ter sido levada a essa região durante o desenvolvimento do FPA (GINTHER, 2007). 


\subsubsection{2 Útero}

O útero também tem sido um dos objetos de estudo da ultrassonografia Doppler em equinos. Já em 1998, Bollwein et al., publicaram um trabalho que mensurou RI na artéria uterina em éguas ao longo do ciclo estral. Eles não encontraram diferenças entre as artérias dos dois lados e perceberam uma alteração em RI entre éguas pluríparas e nulíparas, sendo maior nas primeiras. Também encontraram nos dias 0 e 10 pós ovulação maior RI comparado com os dias 5, 15 e 20, mostrando alterações ao longo do ciclo estral, mas não entre os indivíduos.

Avaliando os cornos uterinos, não foram encontradas diferenças na vascularização entre cornos ipsi ou contralateral ao CL em éguas não cobertas (SHARP, 2000).

Outro aspecto uterino abordado sob o ponto de vista hemodinâmico foi a interação do plasma seminal, diluente e sêmen com o endométrio. Aparentemente somente o diluente não alterou as variáveis analisadas, diferindo do sêmen e plasma seminal. Os autores sugeriram que a inflamação do endométrio e componentes vasodilatadores do plasma seminal foram os prováveis causadores da alteração do fluxo notada no endométrio (BOLLWEIN; SOWADE; STOLLA, 2003).

Ferreira, Gastal e Ginther (2008) estudaram o fluxo sanguíneo uterino em éguas com ou sem cistos uterinos. Os resultados mostraram que existe uma diminuição no fluxo da área cística. Quando os animais foram agrupados em pequena ou grande área cística, a hemodinâmica uterina não foi alterada no primeiro grupo e o fluxo era diminuído no segundo grupo.

Muitos aspectos uterinos ainda podem ser avaliados com esta nova técnica, aliando outra visão de avaliação às técnicas já utilizadas previamente. 


\subsubsection{Gestação}

A gestação em equinos já foi estudada por alguns pesquisadores utilizando a ultrassonografia Doppler. Alguns dos trabalhos serão apresentados a seguir.

Éguas gestantes ou não gestantes não apresentaram vascularização endometrial diferente até o dia 8 pós ovulação. Já entre os dias 12 a 16 uma diferença foi notada, sendo o fluxo endometrial maior nas gestantes. Foi concluído que existem mudanças transitórias na perfusão vascular endometrial acompanhando a localização da vesícula embrionária (SILVA et al., 2005).

A partir do dia 11 pós ovulação, RI e PI foram menores em artérias uterinas de éguas gestantes comparadas com éguas não gestantes. Entre os dia 15 a 29 um maior fluxo sanguíneo, menor RI e maior TAMV foram encontradas para a artéria uterina ipsilateral ao concepto. Uma variação individual de fluxo sanguíneo foi encontrada nestes animais (BOLLWEIN et al., 2003, 2004).

Silva e Ginther (2006) estudaram os aspectos de fluxo sanguíneo durante o processo de fixação e orientação do embrião no útero e detectaram uma indicação vascular precoce na futura posição do embrião em relação ao endométrio. Foi possível encontrar fluxo sanguíneo no embrião a partir do dia 17 a 20. Entretanto a velocidade de detecção deve ser baixada $(4 \mathrm{~cm} / \mathrm{s})$ para permitir a avaliação, pois com velocidades mais altas o fluxo não é detectado (GINTHER, 2007).

Descrevendo um caso de perda embrionária, os autores notaram que os batimentos cardíacos e a vascularização endometrial estavam diminuídas a partir do dia 24, mas a perda ocorreu somente no dia 31. A concentração de progesterona e fluxo sanguíneo luteal estavam dentro dos padrões esperados para a fase de gestação. Fica evidente, portanto, a importância de estudos avaliando perdas embrionárias e vascularização endometrial (GINTHER, 2007).

Ferreira (2012) realizaram um experimento no qual a influência da idade e grau de degeneração endometrial sobre a vascularização uterina foi avaliada. Os resultados mostraram um efeito negativo de ambos na hemodinâmica uterina no início da gestação.

Éguas em final de gestação receberam suplementação com arginina com a intenção de aumentar o fluxo sanguíneo uterino. Os exames foram conduzidos no final da gestação e logo após o parto. Todos os animais apresentaram diminuição de fluxo 
sanguíneo para o útero imediatamente após o parto. 0 tratamento foi capaz de aumentar o fluxo sanguíneo para o corno gravídico e surpreendentemente reduziu a duração da gestação, sem efeitos negativos sobre o potro nascido (MORTENSEN; KELLY; WARREN, 2011). Este estudo demonstrou a possibilidade de realizar mensurações na artéria uterina no final da gestação e a segurança da suplementação da arginina em éguas prenhes .

Este mesmo grupo, ainda com interesse na gestação, estudou os dias 16 a 80 em éguas submetidas a exercício moderado e mediu o fluxo sanguíneo e desenvolvimento embrionário e fetal. Nos animais em exercício foi percebida uma diminuição no fluxo sanguíneo, porém não causando consequente alteração na gestação em desenvolvimento. Curiosamente percebeu-se um aumento no crescimento fetal destes animais (MORTENSEN et al., 2010).

Fica evidente frente ao revisado na literatura, que a ultrassonografia Doppler está sendo cada vez mais utilizada por diversos grupos na Reprodução em equinos e muitas pesquisas podem ser realizadas para determinar aplicações práticas e obter respostas fisiológicas. 
Hípóteses 


\section{HIPÓTESES}

As hipóteses propostas no presente estudo são:

1. A hCG aplicada para induzir a ovulação aumenta o fluxo sanguíneo no útero e no corpo lúteo, torna a morfoecogenicidade uterina mais homogênea, aumenta o tônus uterino e cervical e aumenta a concentração sérica de progesterona;

2. A hCG aplicada no dia da ovulação (d0) aumenta o fluxo sanguíneo no útero e no corpo lúteo, torna a morfoecogenicidade uterina mais homogênea, aumenta o tônus uterino e cervical e aumenta a concentração sérica de progesterona;

3. A hCG aplicada para no 5 dia pós ovulação (d5) aumenta o fluxo sanguíneo no útero e no corpo lúteo, torna a morfoecogenicidade uterina mais homogênea, aumenta o tônus uterino e cervical e aumenta a concentração sérica de progesterona. 
objetivos 


\section{OBJETIVOS}

Diante do exposto, e baseado nos resultados advindos da literatura, bem como os obtidos previamente pelo nosso grupo de pesquisa, os objetivos do presente estudo foram:

- Avaliar os efeitos da aplicação da hCG para induzir a ovulação sobre o fluxo sanguíneo uterino e ovariano, tônus uterino e cervical, morfoecogenicidade uterina, bem como, concentrações séricas de progesterona;

- Avaliar os efeitos da aplicação da hCG no dia 0 (dia da ovulação) sobre o fluxo sanguíneo uterino e ovariano, tônus uterino e cervical, morfoecogenicidade uterina, bem como concentrações séricas de progesterona;

- Avaliar os efeitos da aplicação da hCG no dia 5 (5ํ dia pós ovulação) sobre o fluxo sanguíneo uterino e ovariano, tônus uterino e cervical, morfoecogenicidade uterina, bem como concentrações séricas de progesterona. 
Materiais e Métodos 


\section{MATERIAL E MÉTODOS}

O presente trabalho consistiu em um estudo preliminar e um estudo principal. Esta seção irá pormenorizar os materiais e métodos utilizados tanto no estudo preliminar como no estudo principal.

\subsection{LOCAL E PERÍODO DO EXPERIMENTO}

O estudo preliminar foi realizado na Fazenda Santa Rita, localizada no município de Piracaia- SP, durante os meses de Abril e Maio de 2011. 0 estudo principal foi realizado no mesmo local, durante os meses de Dezembro de 2011 a Abril de 2012.

\subsection{ANIMAIS}

Os animais utilizados no estudo preliminar foram 16 éguas e no estudo principal 12 éguas da raça Mangalarga ou cruza Mangalarga, entre 3 e 14 anos de idade, em bom estado corporal. Um exame clínico reprodutivo foi realizado e foram descartados aqueles que apresentaram quaisquer alterações ovarianas ou uterinas. Ainda, somente animais que apresentaram pelo menos dois ciclos estrais regulares foram incluídos no experimento. Todos os animais haviam recebido, no máximo, uma aplicação prévia de hCG.

\subsection{MANEJO DOS ANIMAIS}

As éguas foram mantidas em piquetes de gramínea Coast Cross (Cynodon dactyolon (L) Pers) e receberam $2 \mathrm{~kg}$ de concentrado diariamente. Sal mineral e água estavam disponíveis ad libitum. 


\subsection{DELINEAMENTO EXPERIMENTAL}

Os dois estudos serão individualmente descritos abaixo.

\subsubsection{Tratamentos}

Nos dois estudos realizados, os animais foram aleatoriamente divididos em 4 grupos experimentais. Somente houve diferença no número de animais, sendo que no estudo preliminar foram utilizados 4 animais, cada animal somente fez parte de um grupo de tratamento e no estudo principal foram utilizados 12 animais, e cada animal foi submetido aleatoriamente a todos os grupos.

G1 (CONTROLE), grupo controle, não foi aplicada a hCG em nenhum momento do ciclo.

G2 (hCG INDUÇÃo OVULAÇÃo): Administração de 2500 UI de hCG intravenoso (Vetecor ${ }^{\circledR}$, Hertape Claire, Espanha, I.V.) quando um folículo atingiu diâmetro igual ou maior a $35 \mathrm{~mm}$, com a presença de edema endometrial.

G3 (hCG d0): Administração de 2500 UI de hCG (Vetecor ${ }^{\circledR}$, I.V.) no dia zero (dia da ovulação).

G4 (hCG d5): Administração de 2500 UI de hCG (Vetecor ${ }^{\circledR}$, I.V.) 5 dias após ovulação. 


\subsubsection{Avaliação do Sistema Reprodutivo}

Os dados foram coletados diariamente entre o dia 0 (dia da ovulação) e o dia 15 (15ํ dia pós ovulação). Todas as avaliações do trato reprodutivo das éguas foram realizadas por um mesmo técnico, que desconhecia os grupos aos quais os animais pertenciam para evitar influência nas análises realizadas.

\subsubsection{Tônus uterino e cervical}

A avaliação do tônus uterino e cervical foi realizada diariamente entre o dia da ovulação e 15 dias após a ovulação (d0 a d15). Durante a palpação transretal, a compressão digital do útero foi realizada, como descrito por Hayes e Ginther (1986). 0 escore variou de 1 a 4, sendo tônus 1 atribuído para o útero flácido e 4 para o útero com o tônus máximo, firme. 0 tônus cervical foi avaliado palpando-se por compressão o assoalho do reto sobre a cérvix, e o escore 1 (mínimo) era dado para a cérvix flácida a 4 (máximo) para a cérvix tubular (Ginther 1992 apud Andrews Mckenzie, 1941).

5.4.2.2 Avaliação ultrassonográfica utilizando modo B

A avaliação ultrassonográfica por modo B foi utilizada para realizar o controle folicular, determinação da ovulação e avaliação do útero e do corpo lúteo. Abaixo serão descritos cada um dos aspectos examinados detalhadamente.

\subsection{Controle da ovulação}

O aparelho de ultrassom M5 VET (Mindray Medical International Limited, China) com transdutor linear multifrequencial ( 6 a $8 \mathrm{Mhz}$ ) foi utilizado para os exames. 
Quando em estro, as éguas foram submetidas a exames ultrassonográficos diários utilizando o modo B, até a ocorrência da ovulação (dia0). Somente no grupo G2, após a detecção de um folículo $\geq 35 \mathrm{~mm}$, com edema uterino evidente, 2500UI de hCG intravenosa foram aplicadas. 0 controle folicular continuou como nos demais grupos até o momento da ovulação.

A partir do dia da detecção da ovulação, todas as éguas (pertencentes aos 4 grupos) foram submetidas a exames ultrassonográficos diários com o modo B e o modo Doppler Colorido, do dia 0 ao dia 15.

\subsection{Morfoecogenicidade uterina}

A avaliação da morfoecogenicidade uterina foi realizada entre o dia 0 e o dia 15 utilizando-se o modo B do aparelho de ultrassom M5 VET. A classificação utilizada foi: escore 1 (útero homogêneo, ecogênico, com pouca diferença entre miométrio e endométrio e com formato tubular), 2 (útero heterogêneo, com mais diferença entre miométrio e endométrio do que o escore 1, formato tubular), 3 (maior diferença entre miométrio e endométrio do que os escores 1 e 2, mais heterogêneo, sendo o edema endometrial ausente) e 4 (útero heterogêneo, pouco ecogênico, com grande diferença entre miométrio e endométrio, com formato pouco tubular, já havendo presença de dobra endometrial) (HAYES; GINTHER, 1986 modificado segundo ALONSO, 2007).

\subsection{Corpo lúteo}

O diâmetro do corpo lúteo foi mensurado diariamente entre o dia da ovulação e 15 dias após ( $\mathrm{d} 0$ a d15), sendo calculada a média da medida em duas imagens transversais congeladas. A área do CL também foi mensurada pela ferramenta do aparelho M5VET de medida de área. $\left(\mathrm{cm}^{2}\right)$. 
5.4.2.3 Avaliação ultrassonográfica utilizando o modo Doppler Colorido

Em todas as avaliações ultrassonográficas o aparelho M5 VET foi utilizado. As configurações do aparelho utilizadas para os exames de Doppler foram: ganho 62, IP4, filtro $100 \mathrm{~Hz}, 4,1 \mathrm{~cm} / \mathrm{s}$ de detecção de fluxo.

\subsection{Corpo lúteo}

O fluxo sanguíneo do CL foi avaliado diariamente entre o dia 0 e o dia 15 por Color Doppler, atribuindo uma nota de 0-100\% com relação aos pontos de fluxo sanguíneo na periferia do CL, em um exame de 1 minuto (GINTHER et al., 2007a), conforme mostrado na figura 1. A análise do pedículo ovariano por escores de 1 a 4 (1 mínimo a 4 máximo) também foi realizada, de acordo com os padrões da figura 2.

Somente no estudo principal foi mensurado o RI de um vaso do pedículo ovariano utilizando-se o modo espectral (GINTHER; UTT, 2004). 
Figura 1- Vascularização do CL

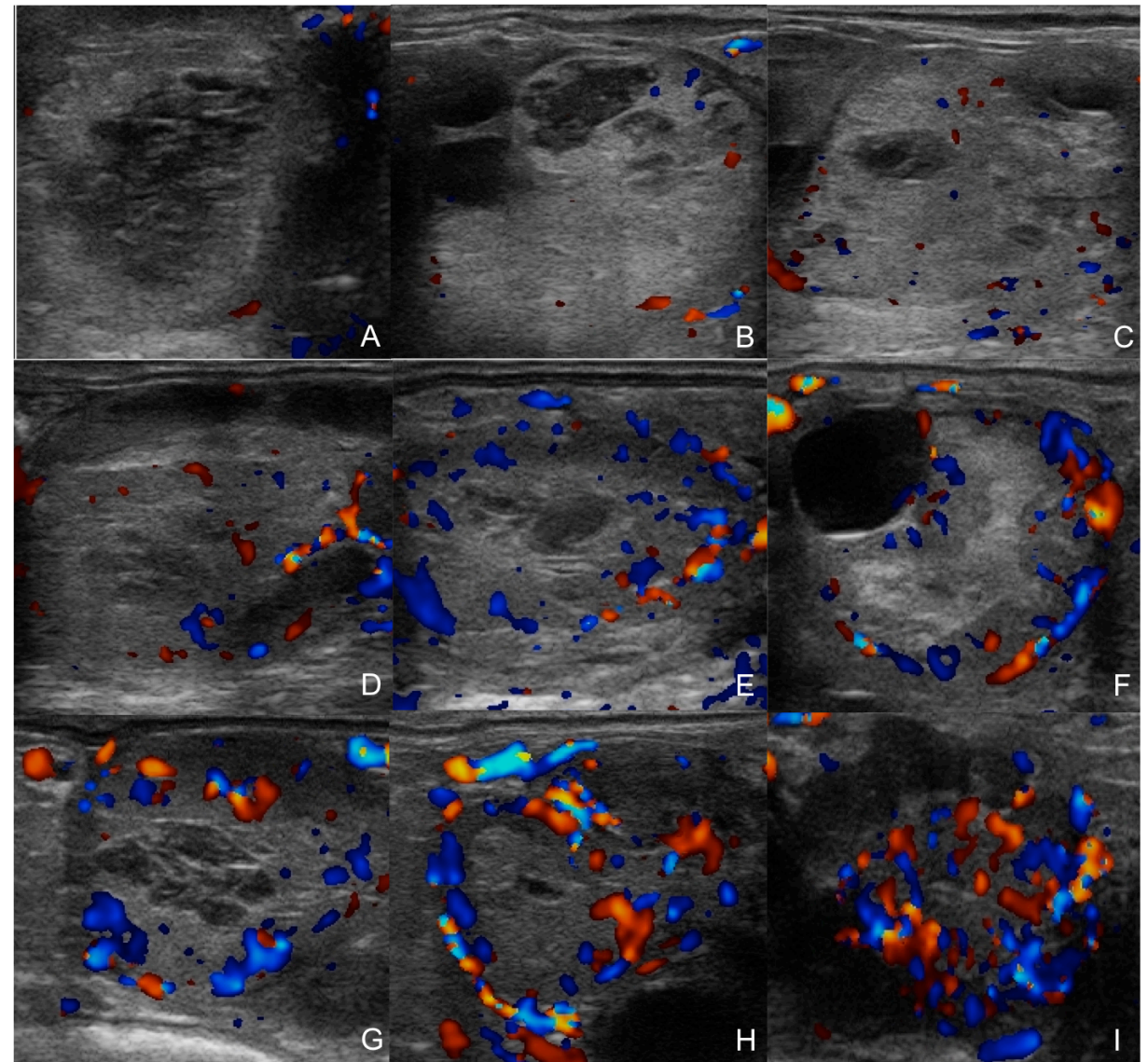

Fonte: Alonso, 2012

Notas: A- 5\% de vascularização; B- 10\% de vascularização; C- 20\% de vascularização; D - 30\% de vascularização; E- 50\% de vascularização; F- 60\% de vascularização; G- 70\% de vascularização; H- 80\% de vascularização; I- 90\% de vascularização 
Figura 2 - Escores de Vascularização do pedículo ovariano

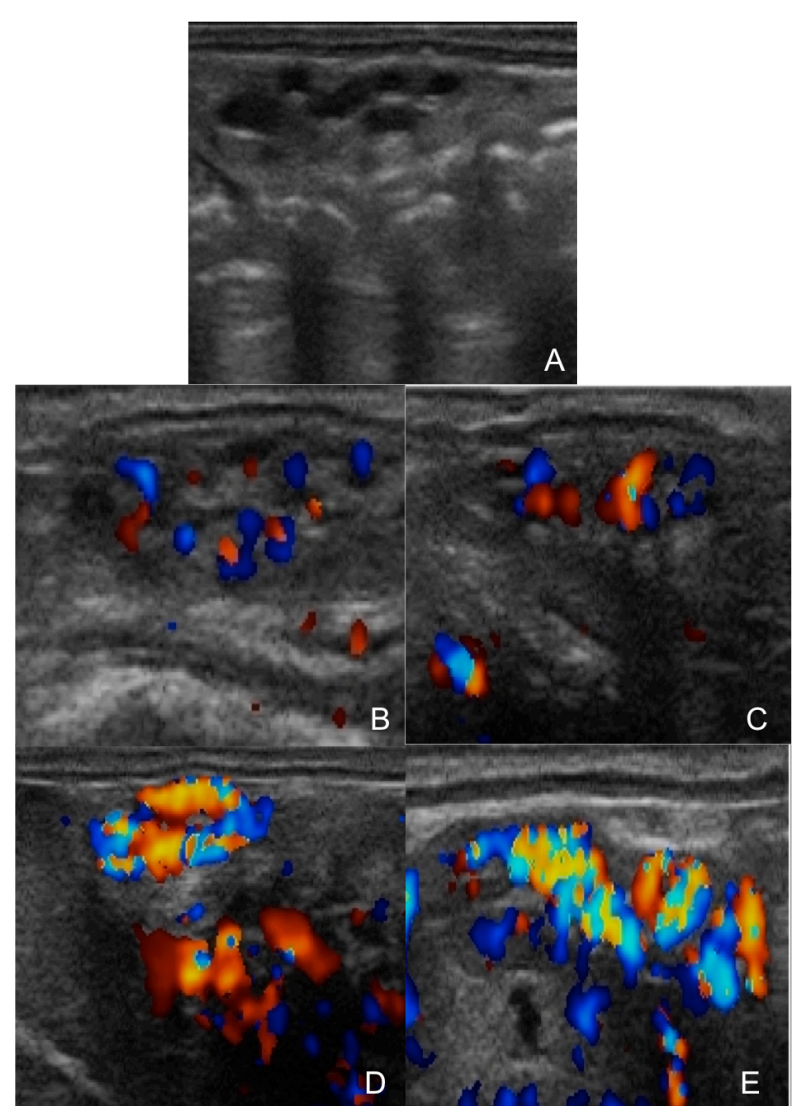

Fonte: Alonso, 2012

Notas: A - Escore 1; B - Escore 2; C - Escore 3; D - Escore 4

\subsection{Endométrio e mesométrio}

A partir do dia 0 até 15 dias após a ovulação utilizou-se o modo Color Doppler para avaliar o endométrio e mesométrio, sempre bilateralmente, utilizando a classificação descrita por Ginther (2007a), sendo 1 (vascularidade mínima) a 4 (vascularidade máxima) (Figuras 3 e 4). 0 lado correspondente ao ovário com o CL será denominado ipsilateral, e o contralateral corresponde ao corno contrário ao CL.

O RI foi mensurado por modo Doppler espectral nas artérias do mesométrio dos dois cornos uterinos somente no estudo principal. 0 valor obtido resultou da média de 3 ciclos cardíacos diferentes entre uma sequência de três espectros Doppler seguidos e idênticos (SILVA et al., 2005; FERREIRA et al., 2008). 
Figura 3- Escores de vascularização do endométrio

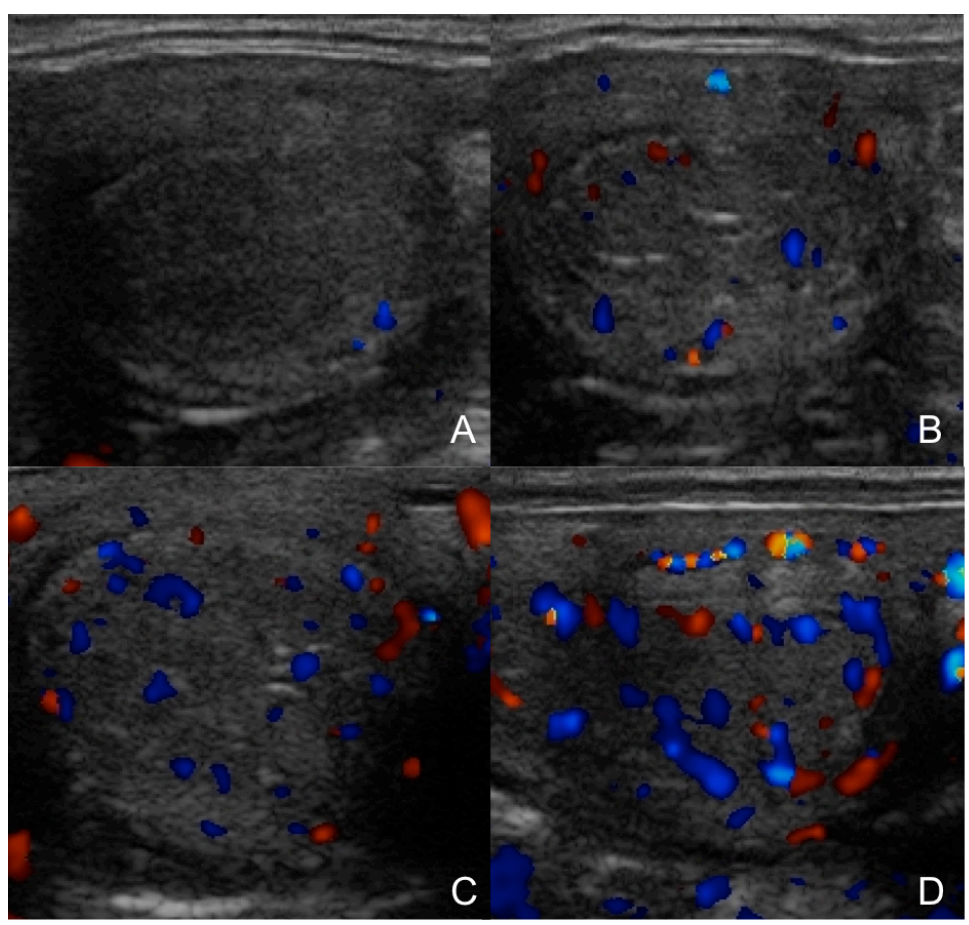

Fonte: Alonso, 2012

Notas: A - Escore 1; B - Escore 2; C - Escore 3; D - Escore 4

Figura 4 - Escores de vascularização do mesométrio

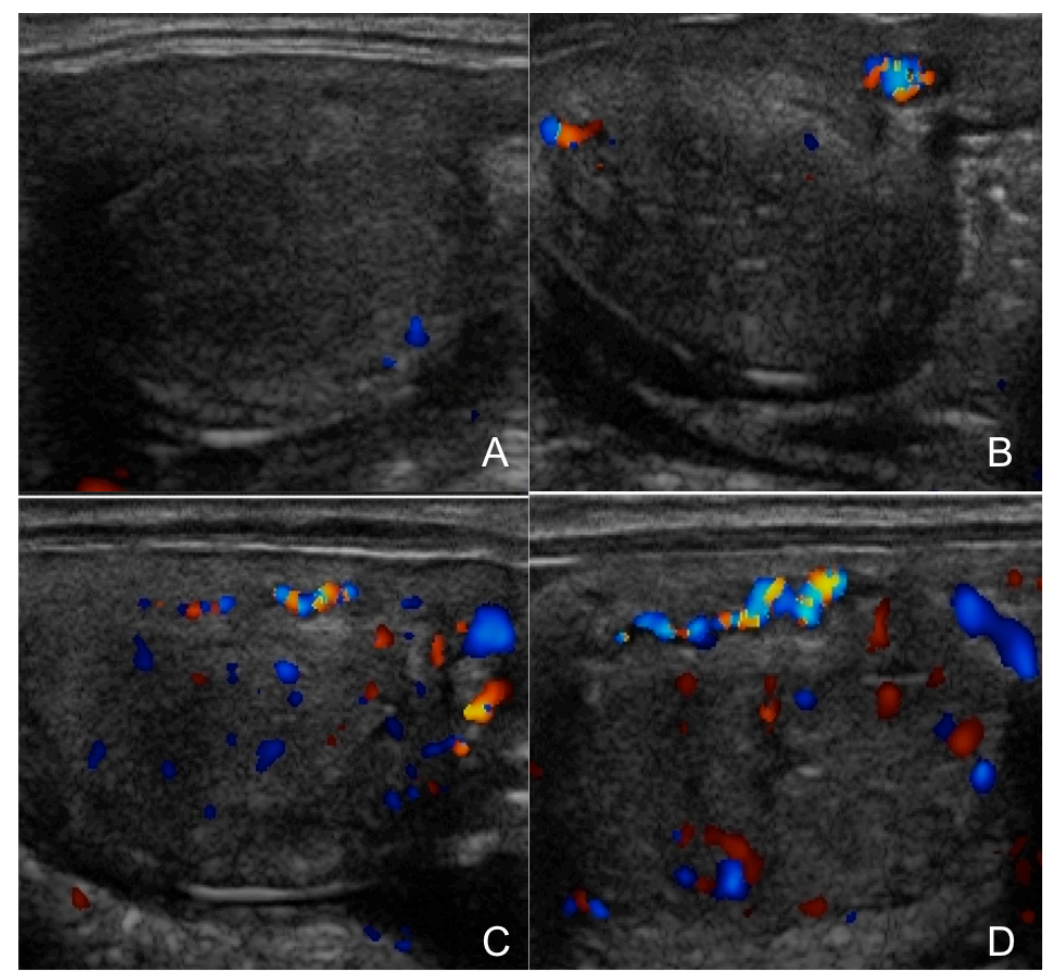

Fonte: Alonso, 2012

Notas: A - Escore 1; B - Escore 2; C - Escore 3; D - Escore 4 


\subsection{ENSAIOS HORMONAIS}

Diariamente, antes do acompanhamento ultrassonográfico, foram coletadas amostras de sangue obtidas por punção da veia jugular, com auxílio de um tubo vacutainer sem anticoagulante. Estas amostras foram coletadas aproximadamente no mesmo horário, entre o dia da ovulação e 15 após ovulação. 0 sangue foi então centrifugado e o soro separado e armazenado a $-20^{\circ} \mathrm{C}$ até posterior análise. Os ensaios de progesterona foram realizados por radioimunoensaio no LDH (Laboratório de Dosagens Hormonais) da Faculdade de Medicina Veterinária e Zootecnia da USP. 0 kit utilizado foi o COAT-A-COUNT, da Siemens. Os coeficientes de variação e nível mínimo detectável nos ensaios realizados estão descritos na tabela 1 abaixo:

Tabela 1 - Sensibilidade, dose mínima detectável, coeficiente de variação intra ensaio e coeficiente de variação inter ensaio dos ensaios de progesterona - São Paulo - 2012

\begin{tabular}{ccccc}
\hline ENSAIO & Sensibilidade $\%$ & Dose (ng/mL) & $\begin{array}{c}\text { CV Intra Ensaio } \\
\text { (baixo) }\end{array}$ & $\begin{array}{c}\text { CV Intra } \\
\text { Ensaio } \\
\text { (alto) }\end{array}$ \\
\hline 1 & 95 & 0,01 & $7,32 \%$ & $8,65 \%$ \\
2 & 95 & 0,005 & $9,66 \%$ & $0,03 \%$ \\
3 & 96 & 0,003 & $5,41 \%$ & $4,04 \%$ \\
4 & 96 & 0,003 & $3,04 \%$ & $6,23 \%$ \\
5 & 95 & 0,003 & $5,04 \%$ & $3,23 \%$ \\
CV Inter ensaio & 95 & 0,003 & $5,1 \%$ & $1,85 \%$ \\
\hline
\end{tabular}

\subsection{ANÁLISE ESTATÍSTICA}

Os dados paramétricos (diâmetro, área do corpo lúteo e concentração sérica de progesterona) foram examinados para normalidade com o teste Kolmogorov-Smirnov. Quando a normalidade do teste foi significante $(p<0,05)$, os dados foram transformados em logaritmos naturais. Comparações entre os grupos tratados e controle foram analisados para efeitos de grupo, dia e interação do grupo com o dia. 0 procedimento misto do SAS (versão 9.2; SAS Institute, Inc., Cary, NC, USA) foi usado com repetida 
Figura 1- Vascularização do CL

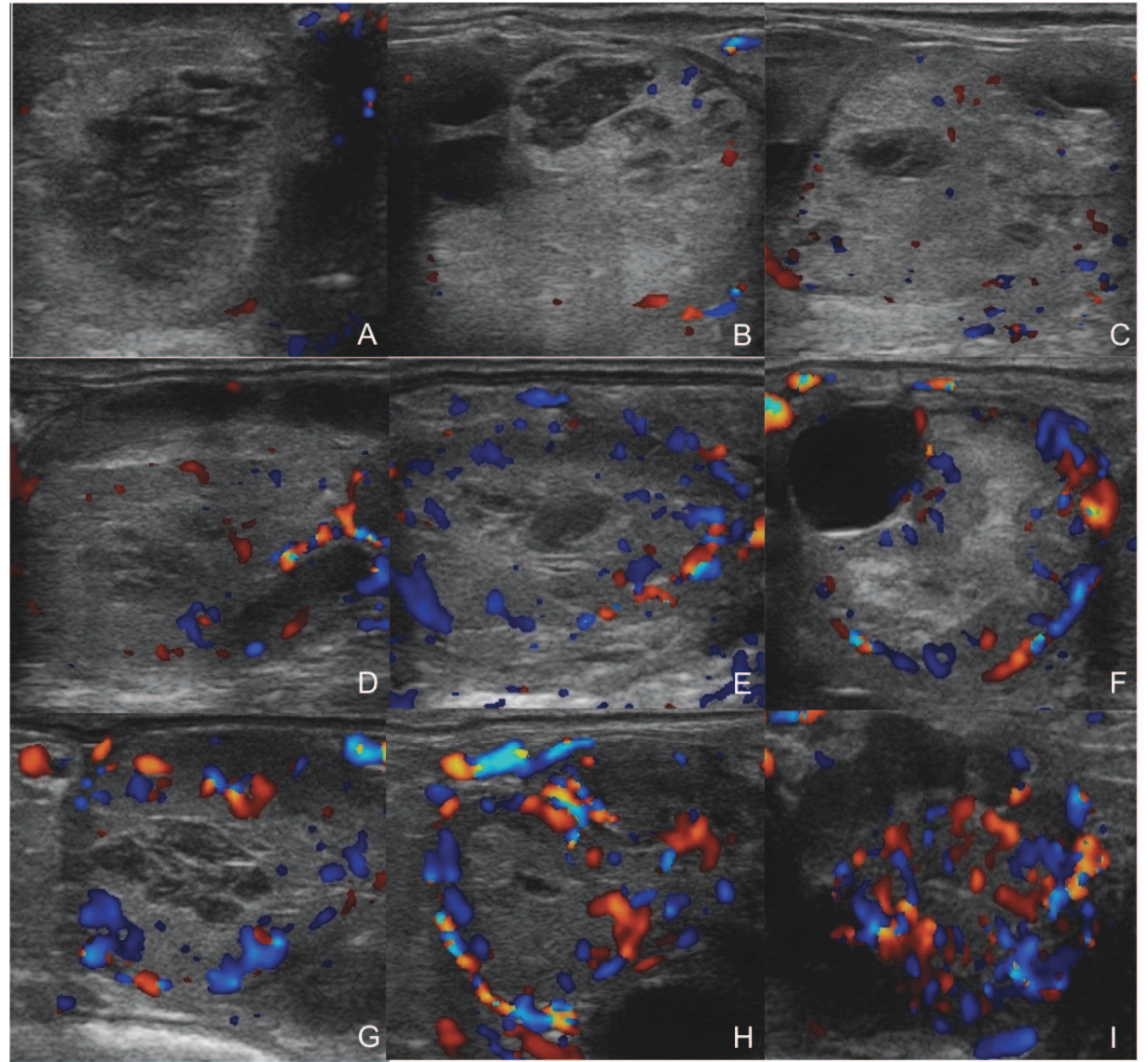

Fonte: Alonso, 2012

Notas: A- 5\% de vascularização; B- 10\% de vascularização; C- 20\% de vascularização; D - 30\% de vascularização; E- 50\% de vascularização; F- 60\% de vascularização; G- 70\% de vascularização; H- 80\% de vascularização; I- 90\% de vascularização 
Figura 2 - Escores de Vascularização do pedículo ovariano

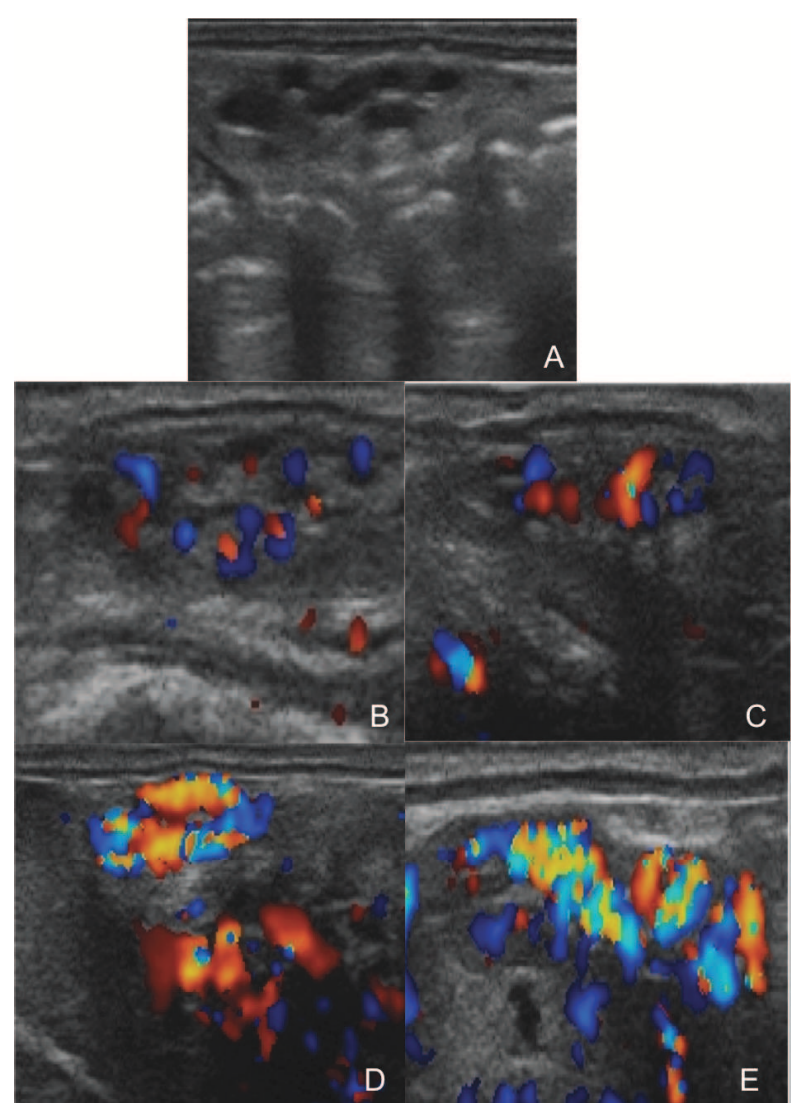

Fonte: Alonso, 2012

Notas: A - Escore 1; B - Escore 2; C - Escore 3; D - Escore 4

\subsection{Endométrio e mesométrio}

A partir do dia 0 até 15 dias após a ovulação utilizou-se o modo Color Doppler para avaliar o endométrio e mesométrio, sempre bilateralmente, utilizando a classificação descrita por Ginther (2007a), sendo 1 (vascularidade mínima) a 4 (vascularidade máxima) (Figuras 3 e 4). 0 lado correspondente ao ovário com o CL será denominado ipsilateral, e o contralateral corresponde ao corno contrário ao CL.

O RI foi mensurado por modo Doppler espectral nas artérias do mesométrio dos dois cornos uterinos somente no estudo principal. 0 valor obtido resultou da média de 3 ciclos cardíacos diferentes entre uma sequência de três espectros Doppler seguidos e idênticos (SILVA et al., 2005; FERREIRA et al., 2008). 
Figura 3- Escores de vascularização do endométrio

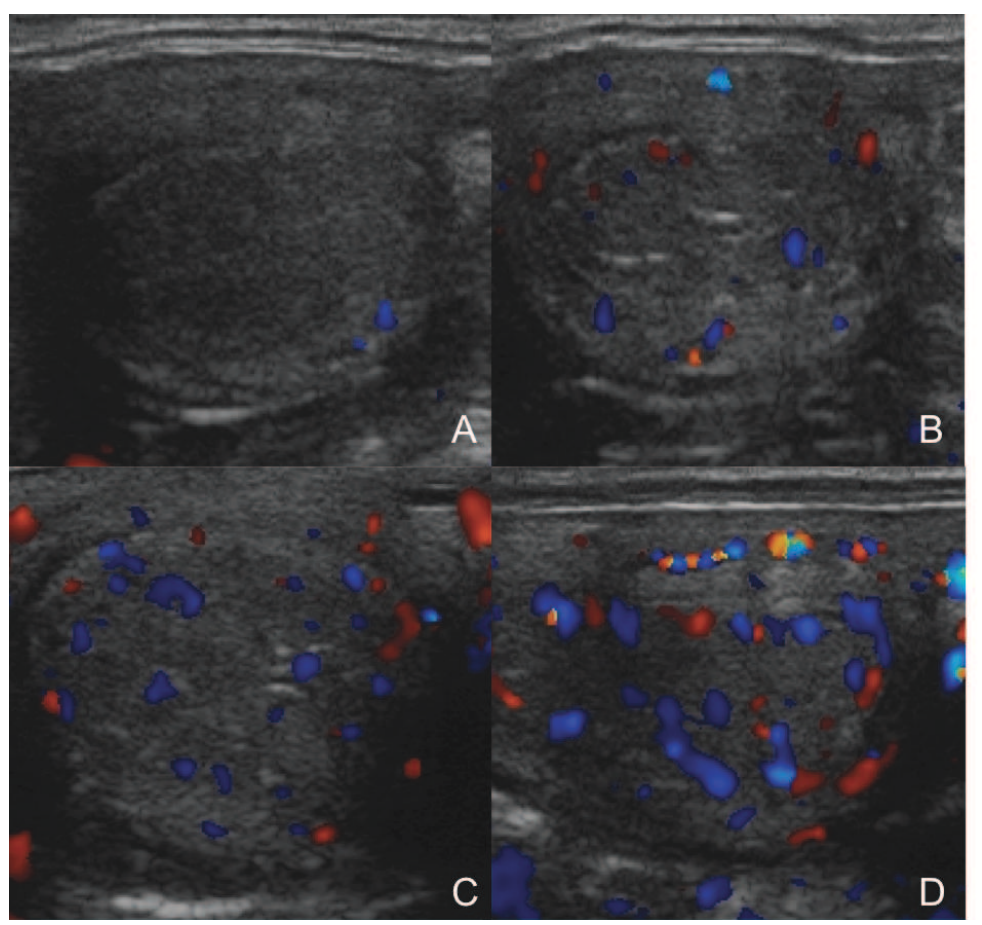

Fonte: Alonso, 2012

Notas: A - Escore 1; B - Escore 2; C - Escore 3; D - Escore 4

Figura 4 - Escores de vascularização do mesométrio

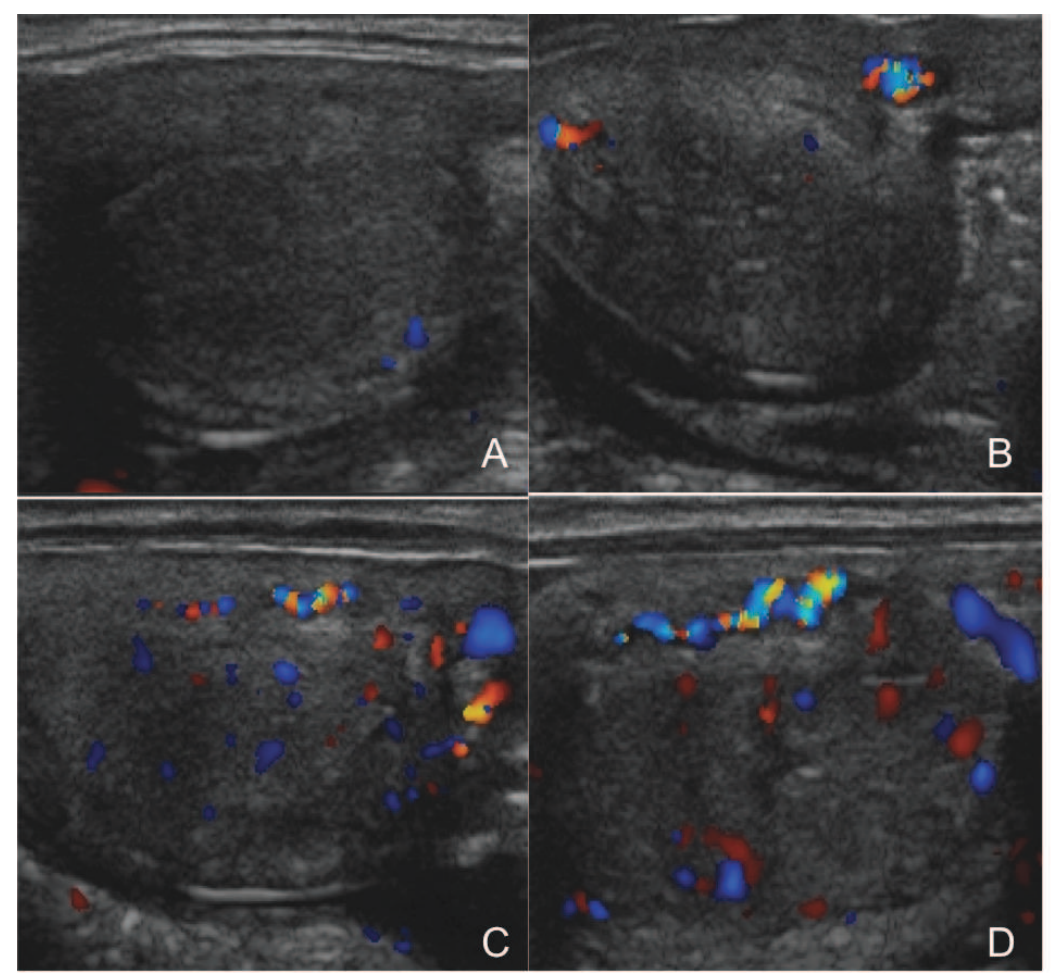

Fonte: Alonso, 2012

Notas: A - Escore 1; B - Escore 2; C - Escore 3; D - Escore 4 


\subsection{ENSAIOS HORMONAIS}

Diariamente, antes do acompanhamento ultrassonográfico, foram coletadas amostras de sangue obtidas por punção da veia jugular, com auxílio de um tubo vacutainer sem anticoagulante. Estas amostras foram coletadas aproximadamente no mesmo horário, entre o dia da ovulação e 15 após ovulação. 0 sangue foi então centrifugado e o soro separado e armazenado a $-20^{\circ} \mathrm{C}$ até posterior análise. Os ensaios de progesterona foram realizados por radioimunoensaio no LDH (Laboratório de Dosagens Hormonais) da Faculdade de Medicina Veterinária e Zootecnia da USP. 0 kit utilizado foi o COAT-A-COUNT, da Siemens. Os coeficientes de variação e nível mínimo detectável nos ensaios realizados estão descritos na tabela 1 abaixo:

Tabela 1 - Sensibilidade, dose mínima detectável, coeficiente de variação intra ensaio e coeficiente de variação inter ensaio dos ensaios de progesterona - São Paulo - 2012

\begin{tabular}{ccccc}
\hline ENSAI0 & Sensibilidade \% & Dose $(\mathrm{ng} / \mathrm{mL})$ & $\begin{array}{c}\text { CV Intra Ensaio } \\
\text { (baixo) }\end{array}$ & $\begin{array}{c}\text { CV Intra } \\
\text { Ensaio } \\
\text { (alto) }\end{array}$ \\
\hline $\mathbf{1}$ & 95 & 0,01 & $7,32 \%$ & $8,65 \%$ \\
2 & 95 & 0,005 & $9,66 \%$ & $0,03 \%$ \\
3 & 96 & 0,003 & $5,41 \%$ & $4,04 \%$ \\
4 & 96 & 0,003 & $3,04 \%$ & $6,23 \%$ \\
5 & 95 & 0,003 & $5,04 \%$ & $3,23 \%$ \\
6 & 95 & 0,003 & $5,1 \%$ & $1,85 \%$ \\
CV Inter ensaio & - & - & $2,97 \%$ & $0,17 \%$ \\
\hline
\end{tabular}

\subsection{ANÁLISE ESTATÍSTICA}

Os dados paramétricos (diâmetro, área do corpo lúteo e concentração sérica de progesterona) foram examinados para normalidade com o teste Kolmogorov-Smirnov. Quando a normalidade do teste foi significante $(p<0,05)$, os dados foram transformados em logaritmos naturais. Comparações entre os grupos tratados e controle foram analisados para efeitos de grupo, dia e interação do grupo com o dia. 0 procedimento misto do SAS (versão 9.2; SAS Institute, Inc., Cary, NC, USA) foi usado com repetida 
Figura 1- Vascularização do CL

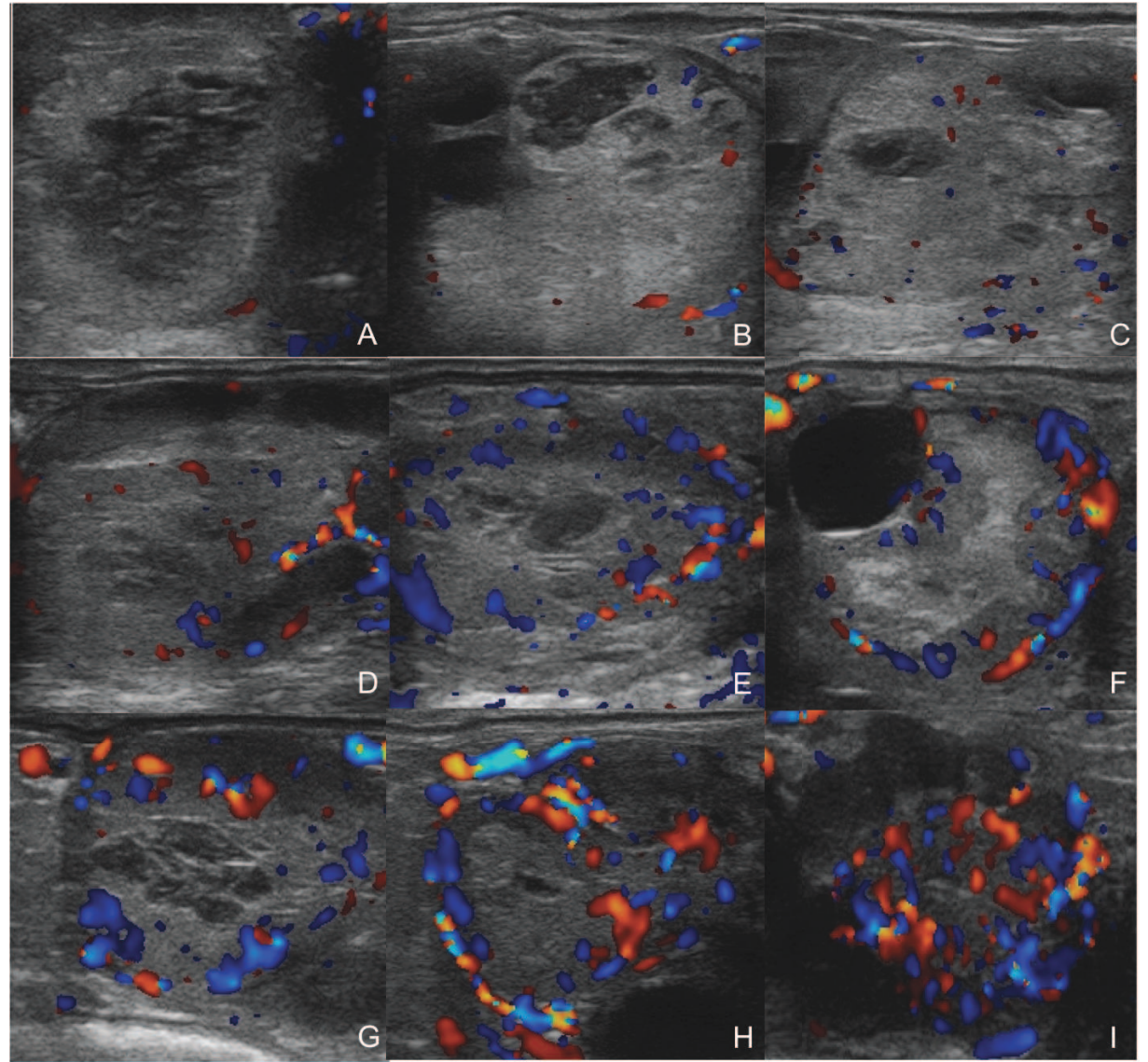

Fonte: Alonso, 2012

Notas: A- 5\% de vascularização; B- 10\% de vascularização; C- 20\% de vascularização; D - 30\% de vascularização; E- 50\% de vascularização; F- 60\% de vascularização; G- 70\% de vascularização; H- 80\% de vascularização; I- 90\% de vascularização 
Figura 2 - Escores de Vascularização do pedículo ovariano

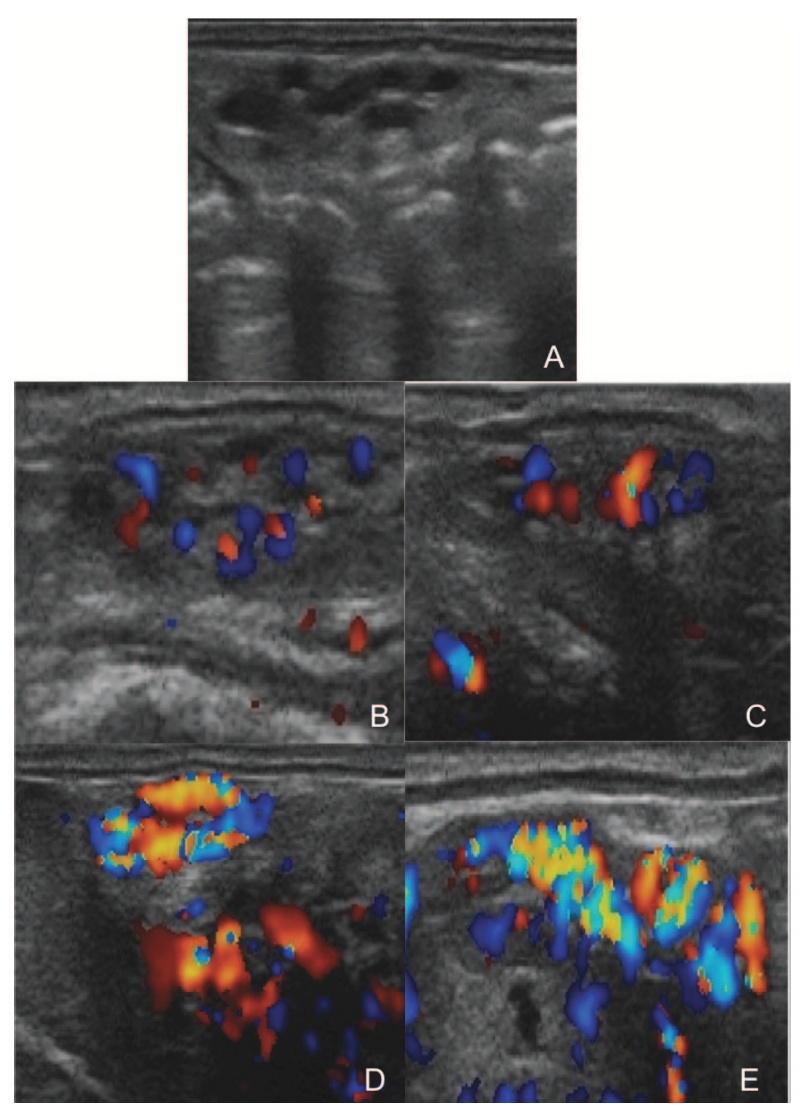

Fonte: Alonso, 2012

Notas: A - Escore 1; B - Escore 2; C - Escore 3; D - Escore 4

\subsection{Endométrio e mesométrio}

A partir do dia 0 até 15 dias após a ovulação utilizou-se o modo Color Doppler para avaliar o endométrio e mesométrio, sempre bilateralmente, utilizando a classificação descrita por Ginther (2007a), sendo 1 (vascularidade mínima) a 4 (vascularidade máxima) (Figuras 3 e 4). 0 lado correspondente ao ovário com o CL será denominado ipsilateral, e o contralateral corresponde ao corno contrário ao CL.

O RI foi mensurado por modo Doppler espectral nas artérias do mesométrio dos dois cornos uterinos somente no estudo principal. 0 valor obtido resultou da média de 3 ciclos cardíacos diferentes entre uma sequência de três espectros Doppler seguidos e idênticos (SILVA et al., 2005; FERREIRA et al., 2008). 
Figura 3- Escores de vascularização do endométrio

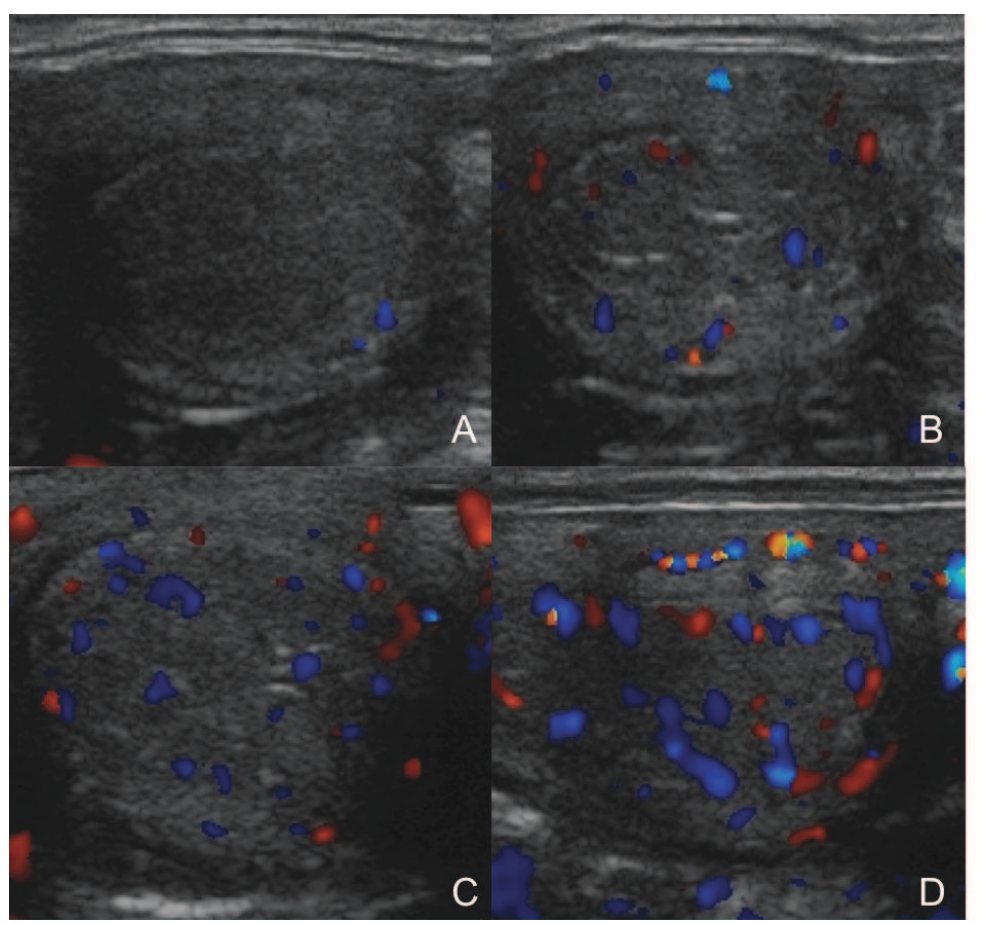

Fonte: Alonso, 2012

Notas: A - Escore 1; B - Escore 2; C - Escore 3; D - Escore 4

Figura 4 - Escores de vascularização do mesométrio

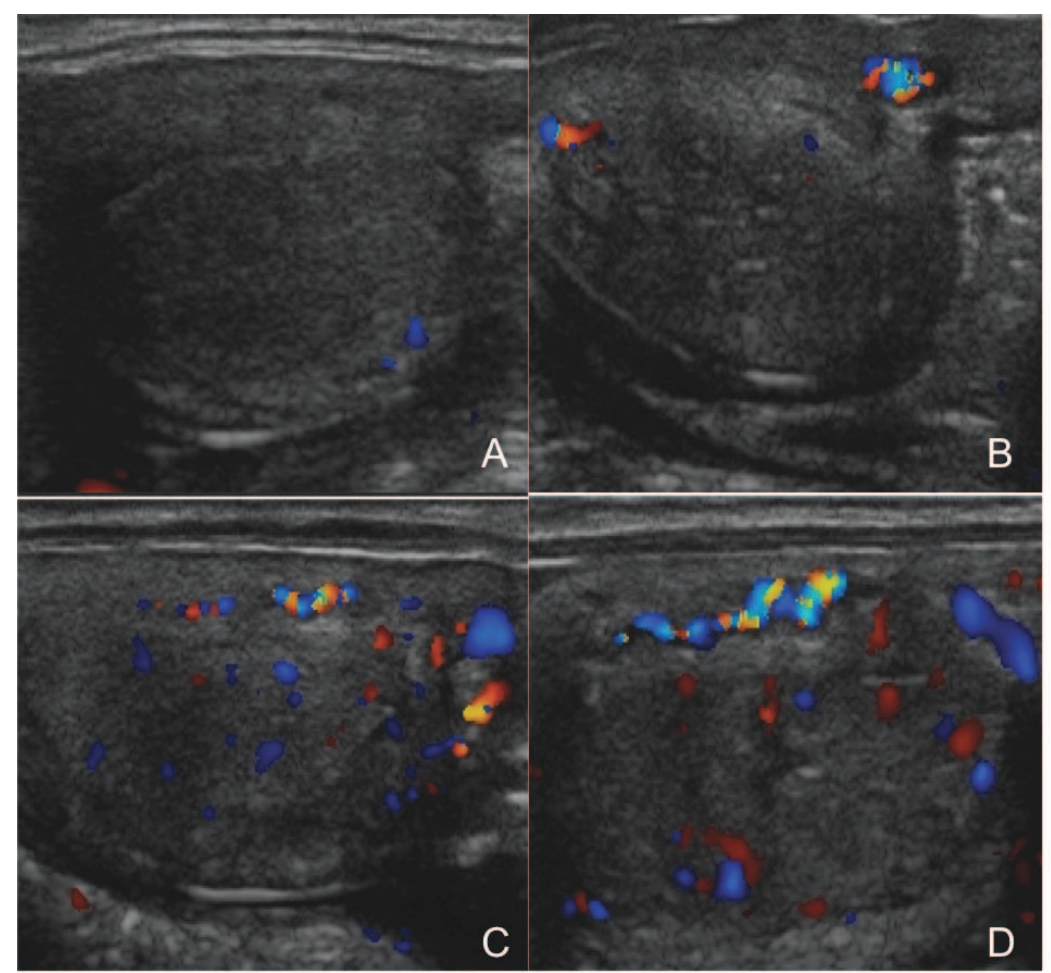

Fonte: Alonso, 2012

Notas: A - Escore 1; B - Escore 2; C - Escore 3; D - Escore 4 


\subsection{ENSAIOS HORMONAIS}

Diariamente, antes do acompanhamento ultrassonográfico, foram coletadas amostras de sangue obtidas por punção da veia jugular, com auxílio de um tubo vacutainer sem anticoagulante. Estas amostras foram coletadas aproximadamente no mesmo horário, entre o dia da ovulação e 15 após ovulação. 0 sangue foi então centrifugado e o soro separado e armazenado a $-20^{\circ} \mathrm{C}$ até posterior análise. Os ensaios de progesterona foram realizados por radioimunoensaio no LDH (Laboratório de Dosagens Hormonais) da Faculdade de Medicina Veterinária e Zootecnia da USP. 0 kit utilizado foi o COAT-A-COUNT, da Siemens. Os coeficientes de variação e nível mínimo detectável nos ensaios realizados estão descritos na tabela 1 abaixo:

Tabela 1 - Sensibilidade, dose mínima detectável, coeficiente de variação intra ensaio e coeficiente de variação inter ensaio dos ensaios de progesterona - São Paulo - 2012

\begin{tabular}{ccccc}
\hline ENSAI0 & Sensibilidade \% & Dose $(\mathrm{ng} / \mathrm{mL})$ & $\begin{array}{c}\text { CV Intra Ensaio } \\
\text { (baixo) }\end{array}$ & $\begin{array}{c}\text { CV Intra } \\
\text { Ensaio } \\
\text { (alto) }\end{array}$ \\
\hline $\mathbf{1}$ & 95 & 0,01 & $7,32 \%$ & $8,65 \%$ \\
2 & 95 & 0,005 & $9,66 \%$ & $0,03 \%$ \\
3 & 96 & 0,003 & $5,41 \%$ & $4,04 \%$ \\
4 & 96 & 0,003 & $3,04 \%$ & $6,23 \%$ \\
5 & 95 & 0,003 & $5,04 \%$ & $3,23 \%$ \\
6 & 95 & 0,003 & $5,1 \%$ & $1,85 \%$ \\
CV Inter ensaio & - & - & $2,97 \%$ & $0,17 \%$ \\
\hline
\end{tabular}

\subsection{ANÁLISE ESTATÍSTICA}

Os dados paramétricos (diâmetro, área do corpo lúteo e concentração sérica de progesterona) foram examinados para normalidade com o teste Kolmogorov-Smirnov. Quando a normalidade do teste foi significante $(p<0,05)$, os dados foram transformados em logaritmos naturais. Comparações entre os grupos tratados e controle foram analisados para efeitos de grupo, dia e interação do grupo com o dia. 0 procedimento misto do SAS (versão 9.2; SAS Institute, Inc., Cary, NC, USA) foi usado com repetida 
afirmação para contar para a auto correlação entre as mensurações sequenciais. Dados não paramétricos (escores da vascularidade do Doppler, morfoecogenicidade uterina, tônus uterino e cervical) foram analisados para potenciais diferenças com o procedimento Glimmix do SAS para determinar os efeitos principais e interações. Um histograma foi feito e uma distribuição Gaussiana foi selecionada como sendo a melhor e utilizada no procedimento Glimmix. Quando houve efeito de dia ou interação foi significante para os dados paramétricos ou não paramétricos, diferenças entre os dias selecionados foram examinadas com o teste $t$ de Student pareado; diferenças entre grupos ou lado do útero em um dia foram examinados com teste não pareado e pareado, respectivamente. Uma probabilidade de $P<0,05$ indicou que a diferença era significante. Os dados estão apresentados como Média \pm Erro Padrão da Média, a menos que indicado. 
Resultados 


\section{RESULTADOS}

\subsection{RESULTADOS DO ESTUDO PRELIMINAR}

A morfoecogenicidade uterina não foi diferente entre os grupos, entretanto houve efeito de dia $(p<0,0001)$. Ela reduziu significativamente entre os dias 0 e $1(p<0,05)$ e atingiu seu valor mínimo no d3. Houve um aumento significativo entre o dia 3 e o dia 6 $(\mathrm{p}<0,05)$. A partir de então, houve um aumento numérico entretanto não estatístico entre o dia 6 até o dia 15 (p>0,05) (Gráfico 1).

Gráfico 1 - Média \pm erro padrão do escore de morfoecogenicidade uterina das éguas nos diferentes tratamentos entre os dias 0 a 15 pós ovulação - Piracaia - 2011

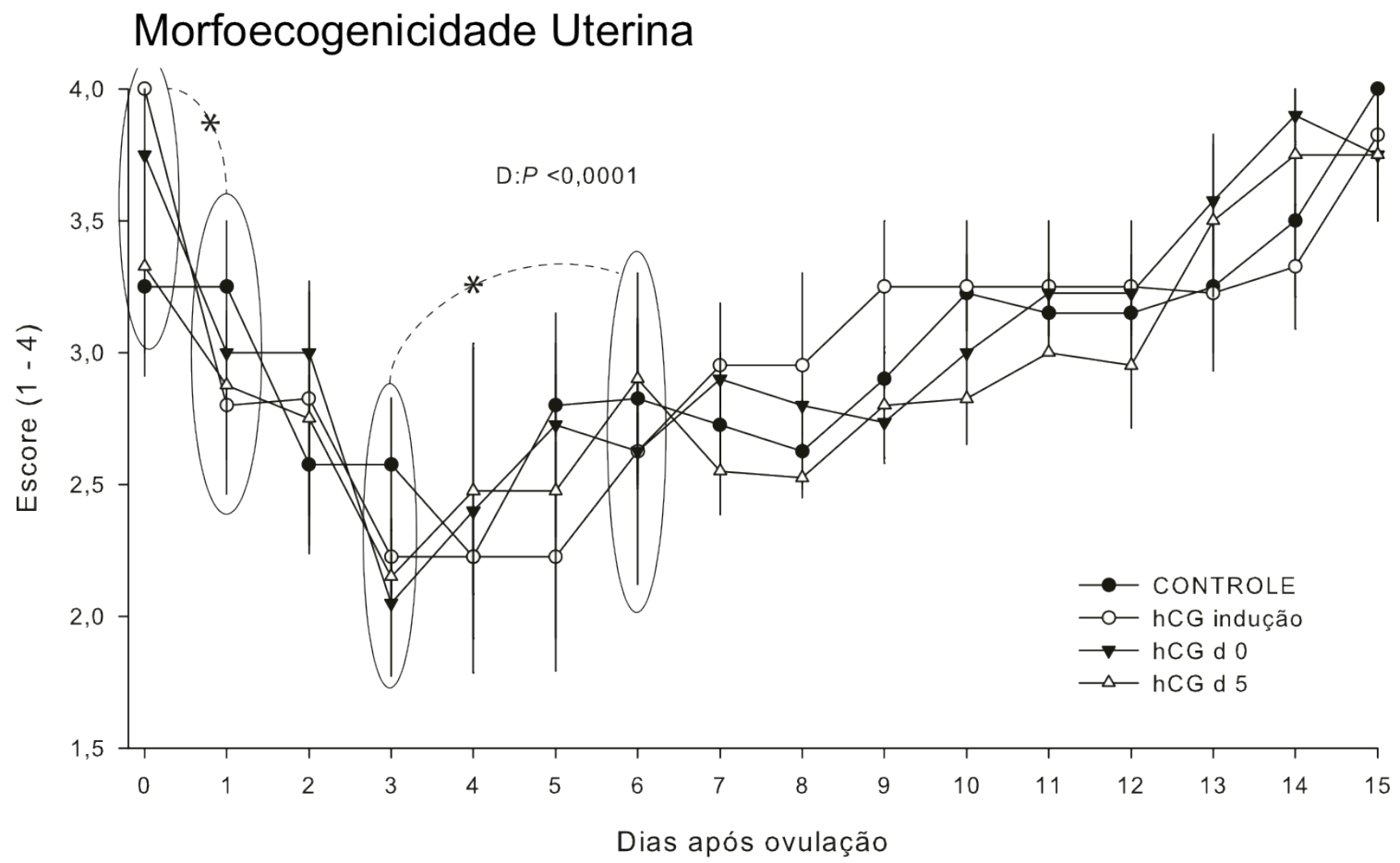

Nota: *Asterisco indica diferença estatística, $\mathrm{P}<0,05$

0 tônus do útero apresentou tendência estatística de efeito de tratamento $(\mathrm{p}<0,0572)$, sendo o grupo controle aquele com os menores escores ao longo dos dias. Houve efeito do dia nesta característica $(\mathrm{p}<0,0001)$. No dia 0 e 1 , o útero estava flácido, e não houve diferença estatística entre estes dias $(p>0,05)$. Houve um aumento significativo $(\mathrm{p}<0,05)$ entre os dias 1 e 2 , atingindo o valor máximo no dia 4 pós 
ovulação. Entre o dia 4 e 5 houve um decréscimo estatisticamente significativo. Do dia 5 em diante houve um decréscimo gradual ao longo dos dias, até o dia 15 quando os valores do escore de tônus estavam baixos novamente, entretanto não foi encontrada diferença estatística entre estes dias ( $p>0,05)$ (Gráfico 2).

Gráfico 2 - Média \pm erro padrão do escore de tônus uterino das éguas nos diferentes tratamentos entre os dias 0 a 15 pós ovulação - Piracaia - 2011

Tônus Uterino

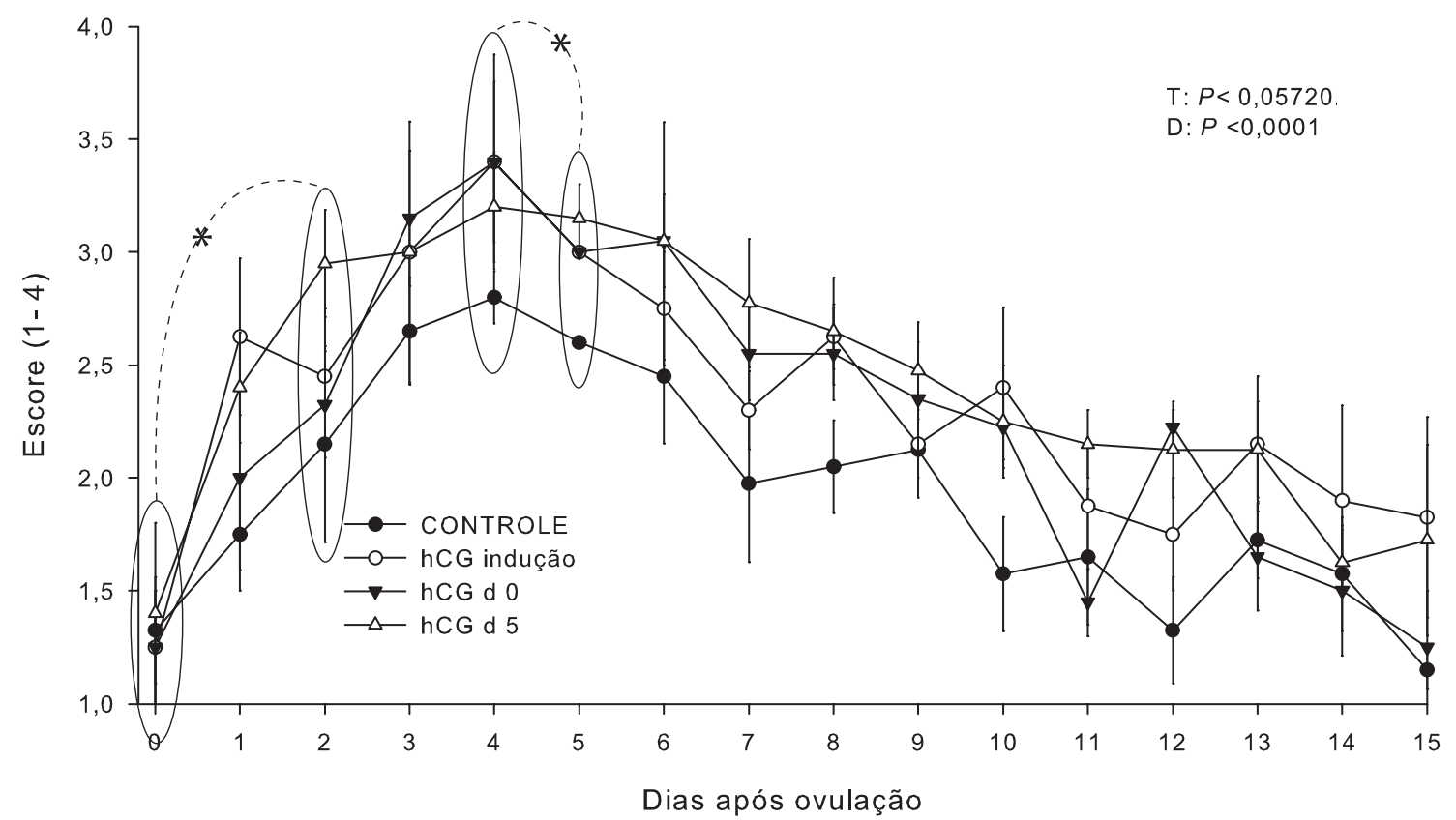

Nota: *Asterisco indica diferença estatística, $\mathrm{P}<0,05$

0 tônus cervical se comportou de forma semelhante a tensão uterina, onde também foi detectado efeito de dia com p<0,0001. Porém, não foi encontrado efeito de tratamento para esta característica $(\mathrm{p}>0,05)$. Houve um incremento de tônus entre o dia da ovulação e o dia 1 , sendo significativo estatisticamente $(\mathrm{p}<0,05)$. Um aumento entre o dia 1 e o dia 6 ocorreu e teve significado estatístico. Um decréscimo entre os dias 6 e 8 foi encontrado, sendo estatisticamente diferente. A partir do dia 8 até o dia 15 não houve diferença estatística entre os escores de tônus cervical ( $\mathrm{P}>0,05)$ (Gráfico 3). 
Gráfico 3 - Média \pm erro padrão do escore de tônus cervical das éguas nos diferentes tratamentos entre os dias 0 a 15 pós ovulação - Piracaia - 2011

\section{Tônus Cervical}

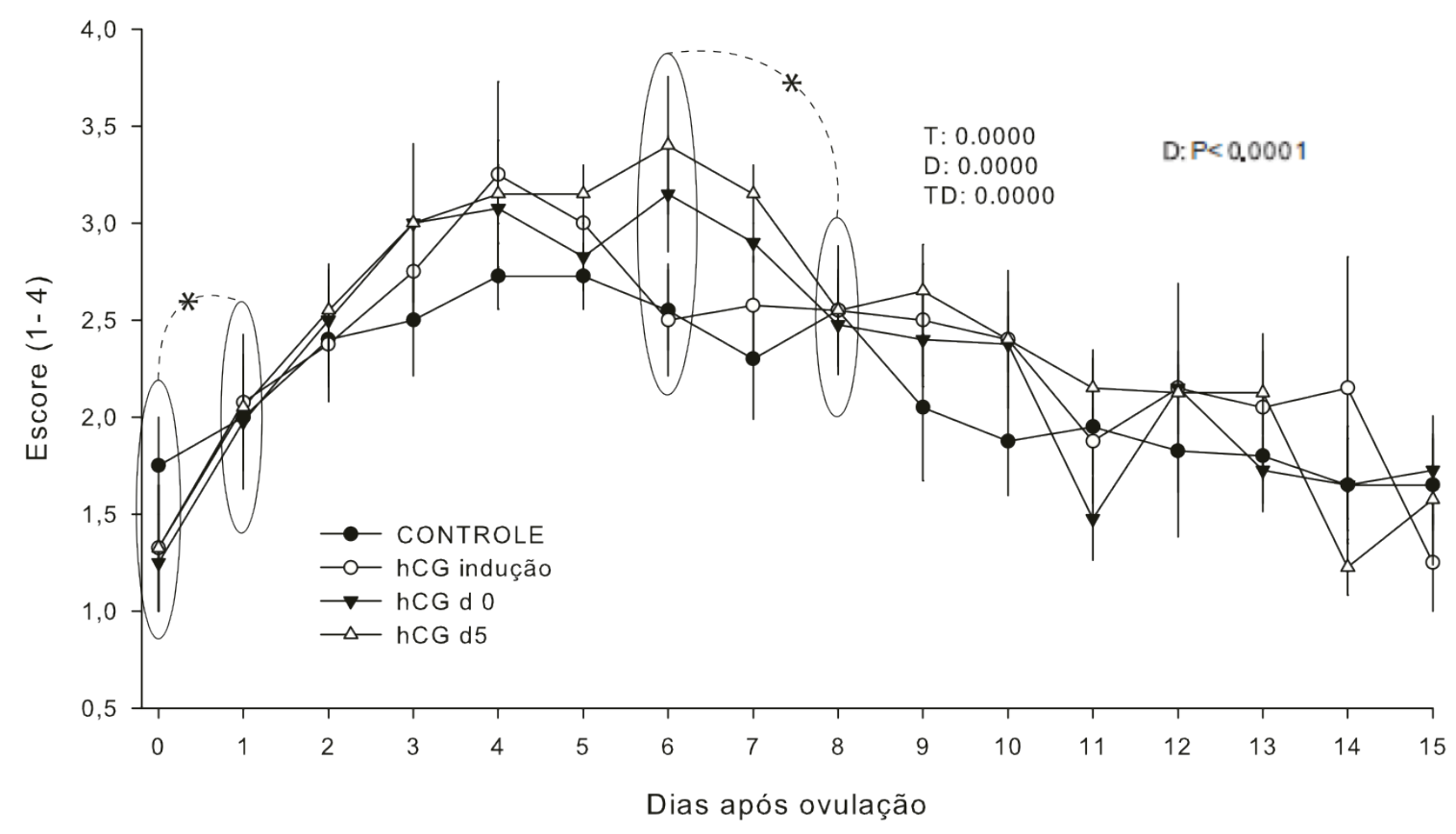

Nota: *Asterisco indica diferença estatística, $\mathrm{P}<0,05$

A área do CL também sofreu efeito do dia $(\mathrm{p}<0,0001)$ e não apresentou efeito do tratamento $(\mathrm{p}>0,05)$. Entre os dias 0 e 2 um aumentou na área foi notado, com significado estatístico $(\mathrm{p}<0,05)$. Entre os dias 6 e 7 uma diminuição aconteceu na área do $\mathrm{CL}$, sendo estatisticamente diferente $(\mathrm{p}<0,05)$. Deste momento em diante um decréscimo na área ocorreu até o d15, entretanto não foi detectada diferença estatística entre os dias $(p>0,05)$ (Gráfico 4). 
Gráfico 4 - Média \pm erro padrão da área do corpo lúteo das éguas nos diferentes tratamentos entre os dias 0 a 15 pós ovulação - Piracaia - 2011

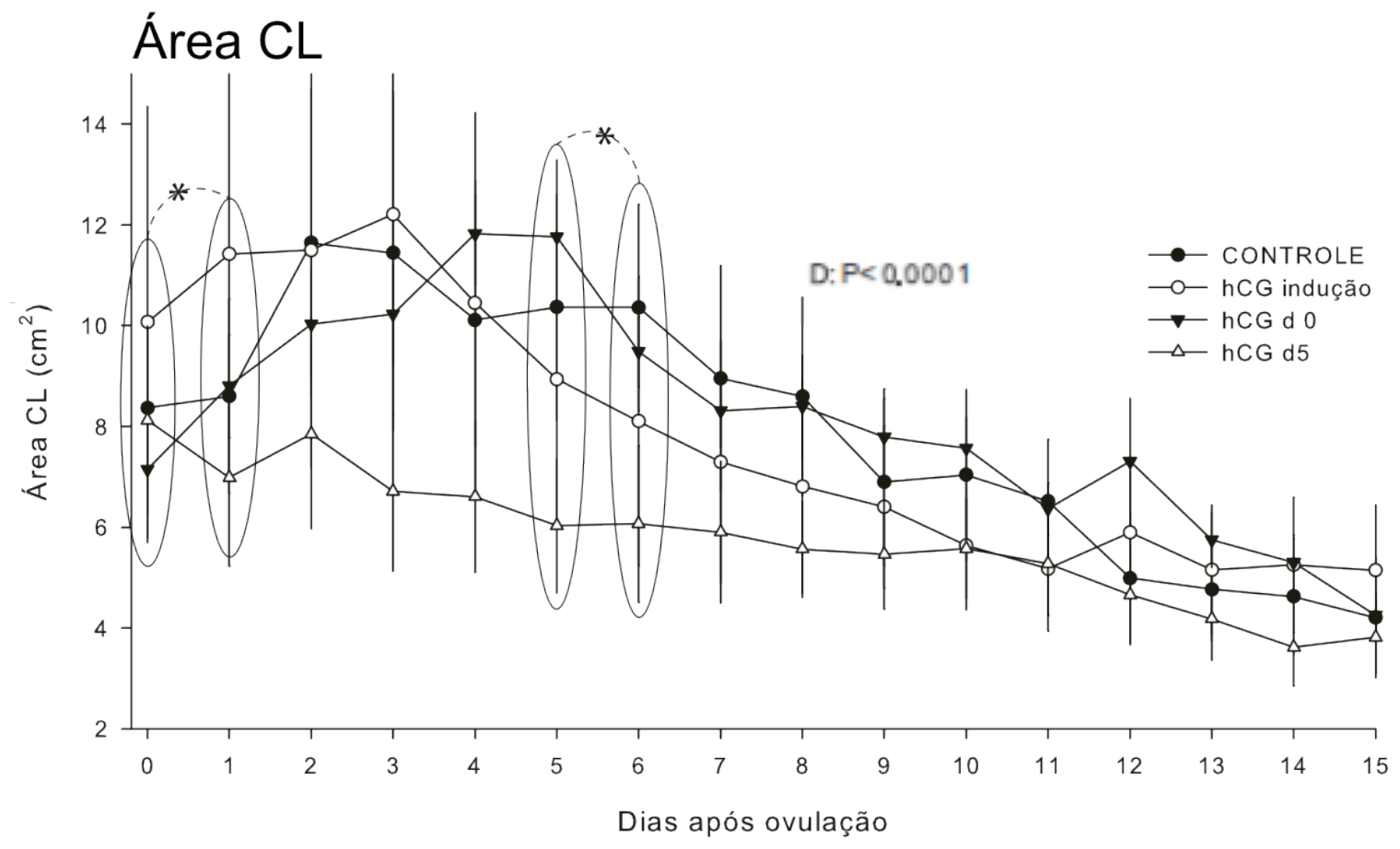

Nota: *Asterisco indica diferença estatística, $\mathrm{P}<0,05$

0 diâmetro do CL apresentou efeito de dia ( $\mathrm{p}<0,0001)$, mas não de tratamento $(p>0,05)$. Somente entre o d1 e d7 houve um decréscimo estatístico no diâmetro. A partir do d7, o diâmetro do CL diminuiu ao longo dos dias (Gráfico 5). 
Gráfico 5- Média \pm erro padrão do diâmetro do corpo lúteo das éguas nos diferentes tratamentos entre os dias 0 a 15 pós ovulação - Piracaia - 2011

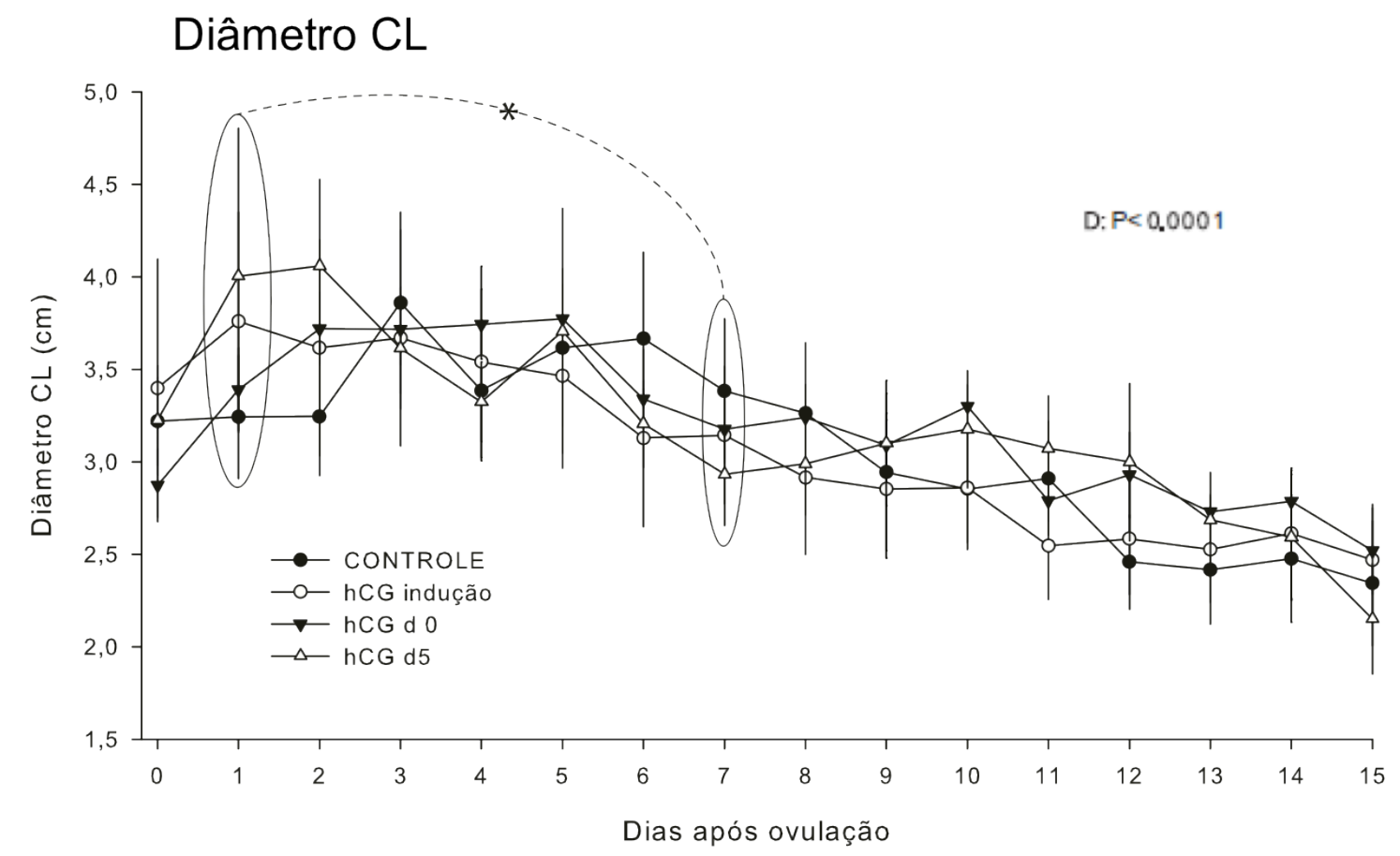

Nota: *Asterisco indica diferença estatística, $\mathrm{P}<0,05$

A porcentagem de vascularização do CL apresentou efeito de dia $(\mathrm{p}<0,0001)$. Entretanto também foi detectado um efeito de tratamento $(\mathrm{p}<0,0001)$. 0 grupo G3 (hCG d0) apresentou uma vascularização mais alta significativamente com relação ao grupo Controle e G4 (hCG d5) no dia 11 e no dia 15. No dia 14 pós ovulação o grupo G3 era estatisticamente diferente do controle, com maior vascularização $(\mathrm{p}<0,0001)$. No d15 o grupo hCG d0 teve valor de vascularização superior que os grupos controle e hCG no d5, com significado estatístico $(\mathrm{p}<0,0001)$. Ao longo dos dias a vascularização aumentou entre os dias 0 e 2, atingindo valores máximos no dia 5 pós ovulação. Somente houve diferença estatística entre os dias 5 e 13 pós ovulação, quando um decréscimo foi visto. (Gráfico 6). 
Gráfico 6 - Média \pm erro padrão da porcentagem de vascularização do corpo lúteo das éguas nos diferentes tratamentos entre os dias 0 a 15 pós ovulação - Piracaia - 2011

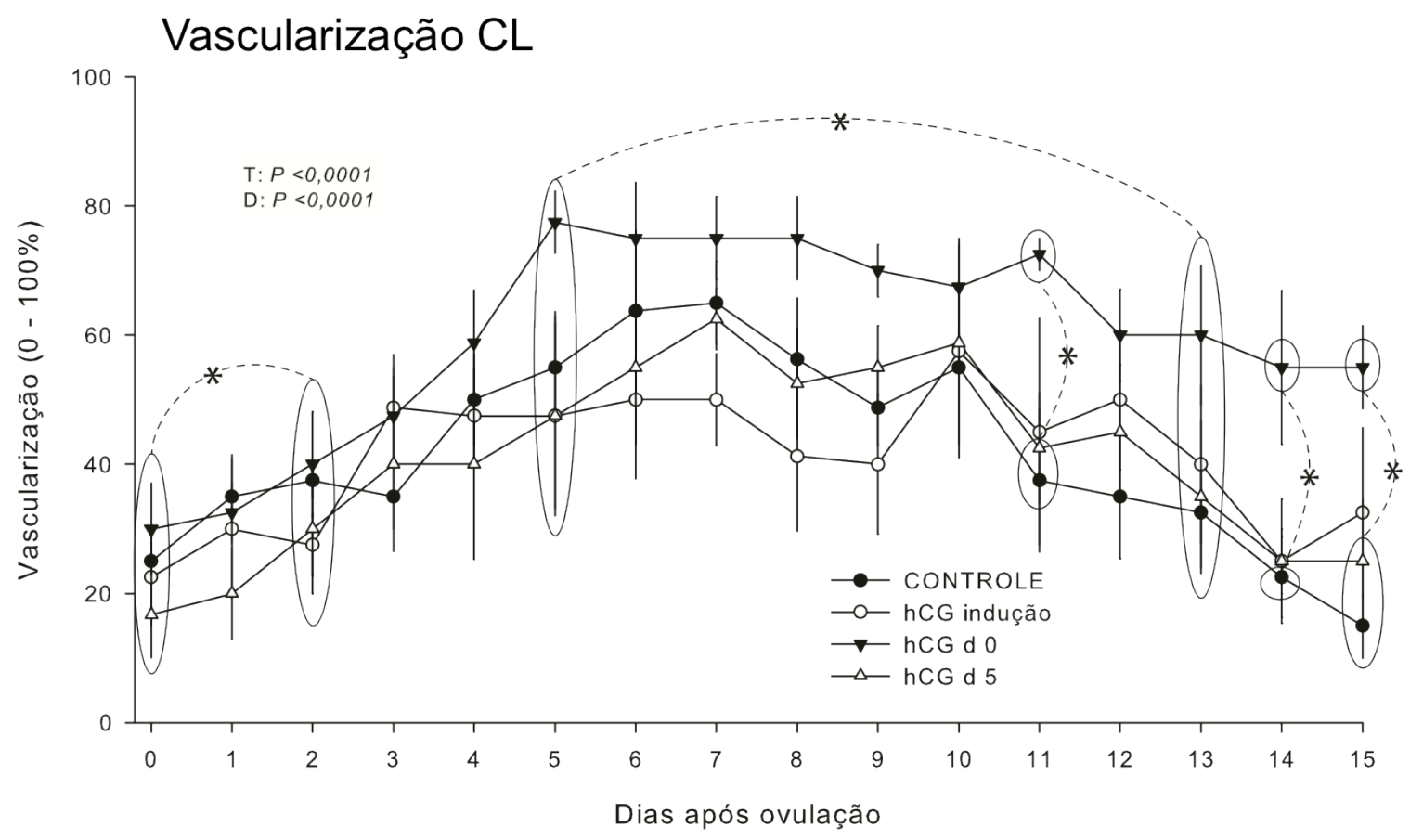

Nota: *Asterisco indica diferença estatística, $\mathrm{P}<0,05$

Os escores de vascularização do pedículo ovariano foram avaliados. Um efeito de dia $(p<0,0001)$ foi encontrado. Também um efeito de tratamento pode ser visto $(\mathrm{p}<0,0476)$. Entre os dias 0 e 3 houve um aumento da vascularização do pedículo, que se manteve constante até o dia 14 pós ovulação, quando sofreu uma queda $(p<0,05)$ (Gráfico 7). 
Gráfico 7 - Média \pm erro padrão do escore de vascularização do pedículo ovariano em éguas nos diferentes tratamentos entre os dias 0 a 15 pós ovulação - Piracaia - 2011

\section{Vascularização do Pedículo Ovariano}

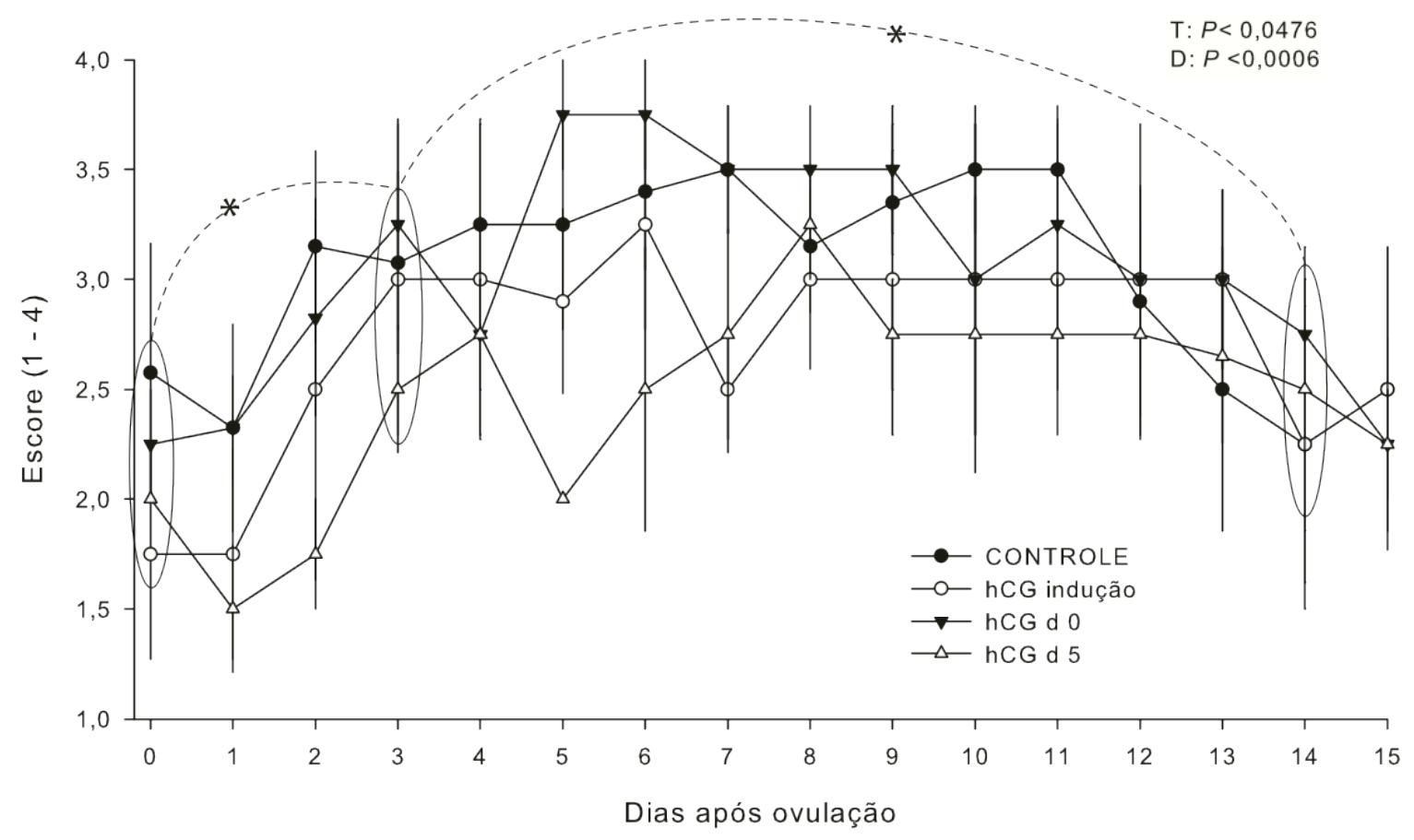

Nota: *Asterisco indica diferença estatística, $\mathrm{P}<0,05$

Os dados do endométrio ipsilateral e contralateral ao CL foram comparados e não houve diferença estatística entre eles. Desta forma, a média dos escores dos dois cornos foi realizada e considerou-se o valor do endométrio geral. 0 efeito de dia foi detectado $(\mathrm{p}<0,0001)$ e não o de tratamento $(\mathrm{p}>0,05)$. Entre os dias 0 e 1 , houve um aumento na vascularização endometrial significativo $(\mathrm{p}<0,05)$. Apesar do aumento numérico dos escores, somente foi detectado aumento significativo do escore entre os dias 1 e 4 pós ovulação. Um decréscimo foi encontrado entre os dias 4 e 9 pós ovulação, com significado estatístico ( $\mathrm{p}<0,05)$ (Gráfico 8). 
Gráfico 8 - Média \pm erro padrão do escore de do endométrio nas éguas nos diferentes tratamentos entre os dias 0 a 15 pós ovulação - Piracaia - 2011

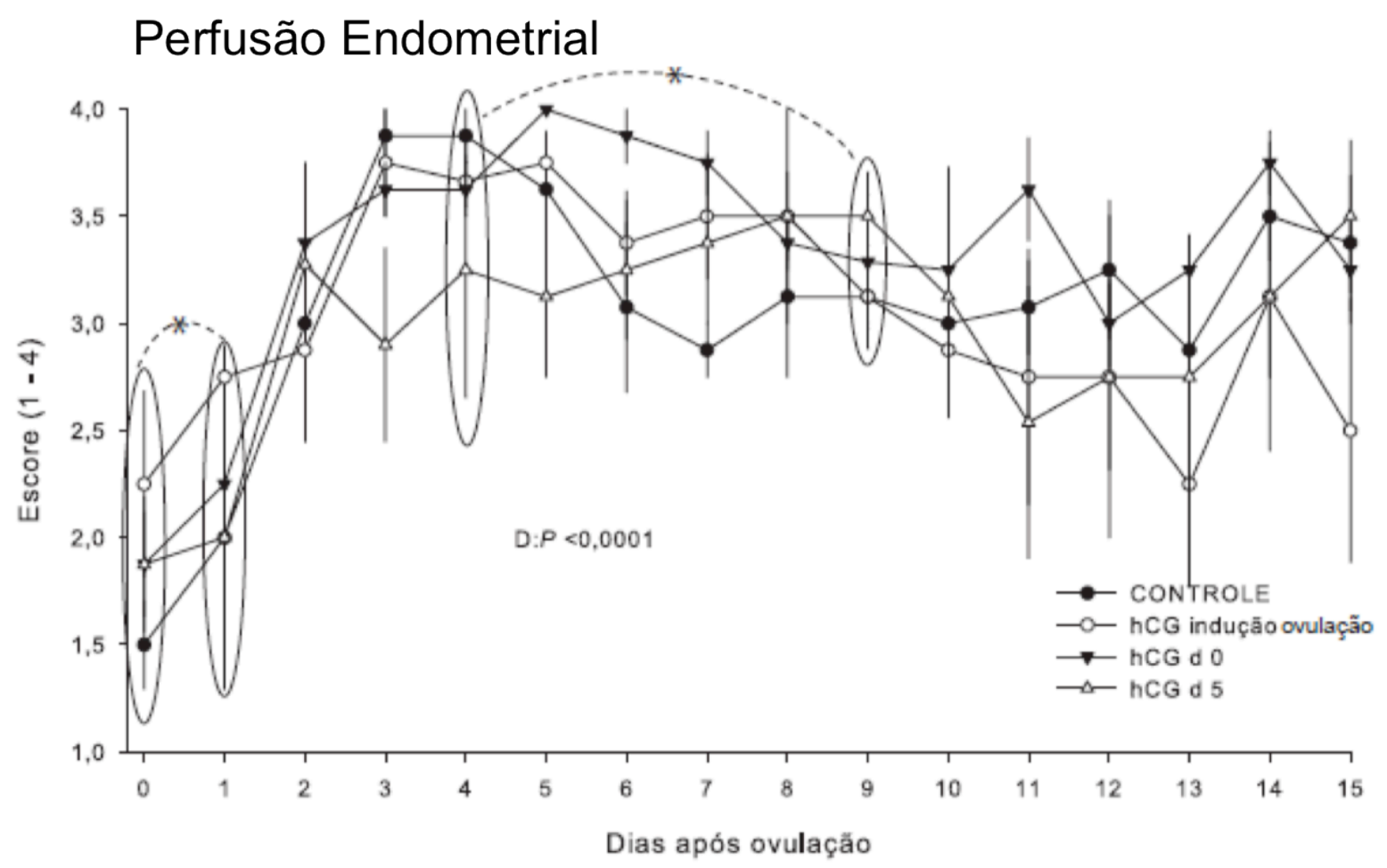

Nota: *Asterisco indica diferença estatística, $\mathrm{P}<0,05$

Os escores de vascularização dos mesométrios contra e ipsilateral ao CL também foram avaliados para verificar se havia ou não diferença estatística entre eles. Uma diferença entre os dois foi detectada, e desta forma, eles serão aqui considerados separadamente. 0 mesométrio contralateral apresentou efeito do dia $(p<0,0001)$, porém não houve efeito de tratamento $(p>0,05)$. Um aumento significativo da vascularização ocorreu entre os dias 0 e 1 pós ovulação. Uma diminuição da vascularização foi encontrada entre os dias 4 e 8 pós ovulação, sendo estatisticamente significante $(\mathrm{p}<0,05)$ (Gráfico 9). 
Gráfico 9 - Média \pm erro padrão do escore de vascularização do mesométrio contralateral nas éguas nos diferentes tratamentos entre os dias 0 a 15 pós ovulação - Piracaia - 2011

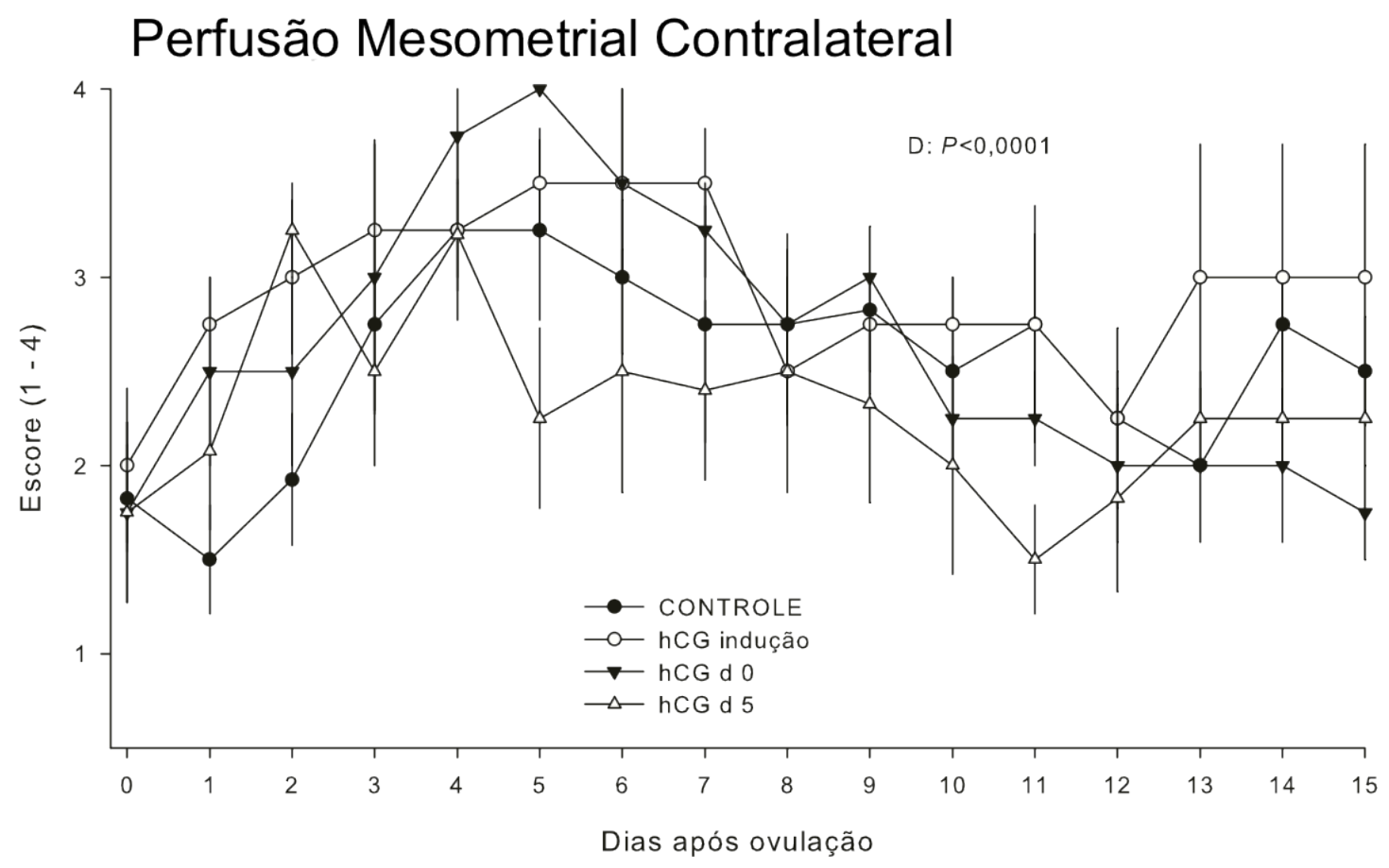

Nota: *Asterisco indica diferença estatística, $\mathrm{P}<0,05$

0 mesométrio ipsilateral ao CL, semelhante ao anterior apresentou efeito de dia $(\mathrm{p}<0,0001)$ e não apresentou efeito de tratamento $(\mathrm{p}>0,05)$. Entre os dias 0 e 2 um aumento de vascularização se iniciou, com significado estatístico $(p<0,05)$. Um decréscimo entre os dias 5 e 8 que diferiu estatisticamente aconteceu $(p<0,05)($ Gráfico $10)$. 
Gráfico 10 - Média \pm erro padrão do escore de vascularização do mesométrio ipsilateral nas éguas nos diferentes tratamentos entre os dias 0 a 15 pós ovulação - Piracaia - 2011

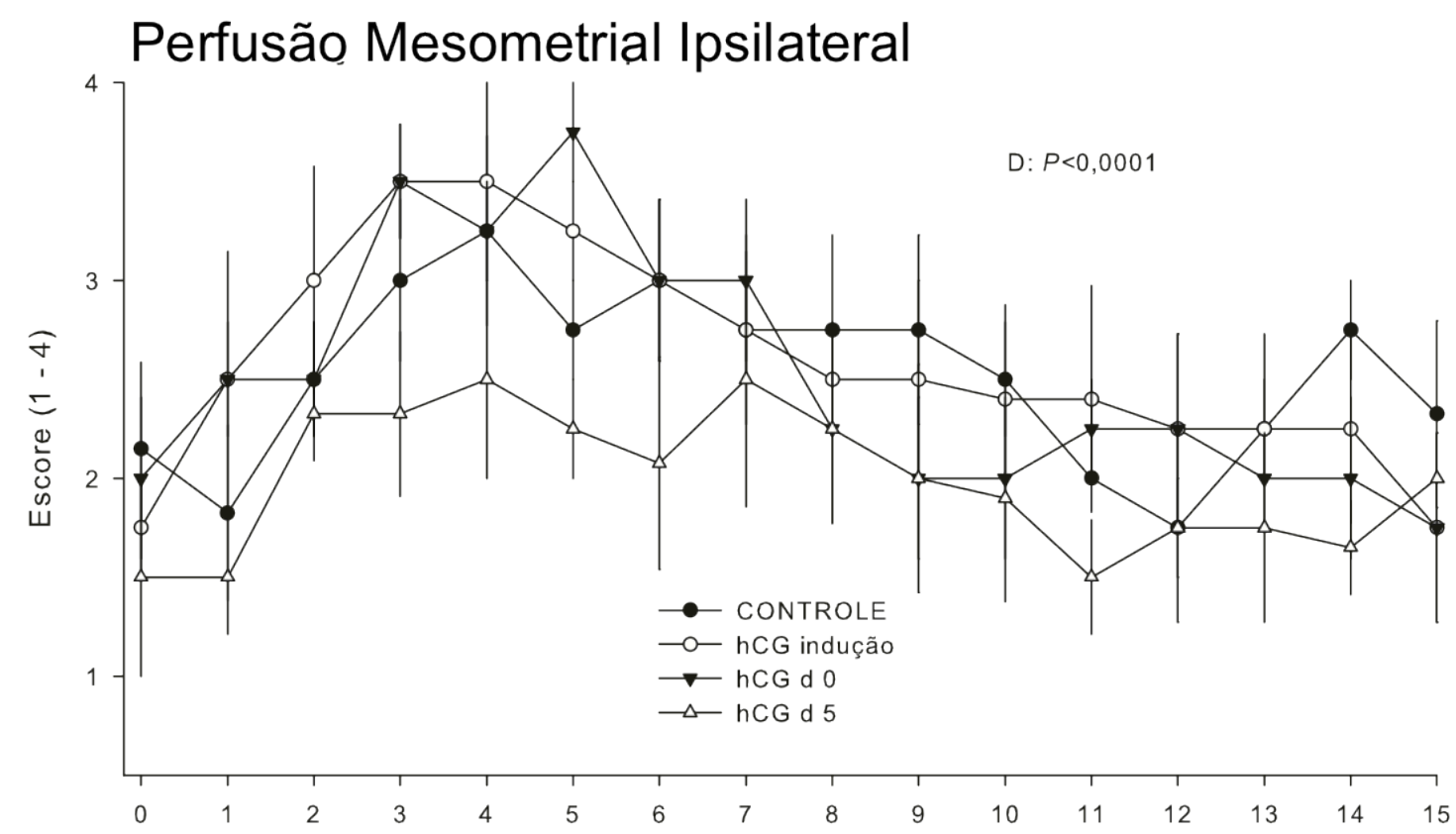

Nota: *Asterisco indica diferença estatística, $\mathrm{P}<0,05$

As concentrações séricas de progesterona não sofreram efeito de tratamento, apenas efeito de dia. Houve um aumento entre os dias 0 e 1 pós ovulação, que continuou até atingir os valores máximos nos dias 5 até 10 pós ovulação. A partir de então, uma diminuição foi encontrada que permaneceu até o dia 15 pós ovulação (Gráfico 11). 
Gráfico 11 - Concentração sérica de progesterona nas éguas nos diferentes tratamentos entre os dias $0 \mathrm{a}$ 15 pós ovulação - Piracaia - 2011

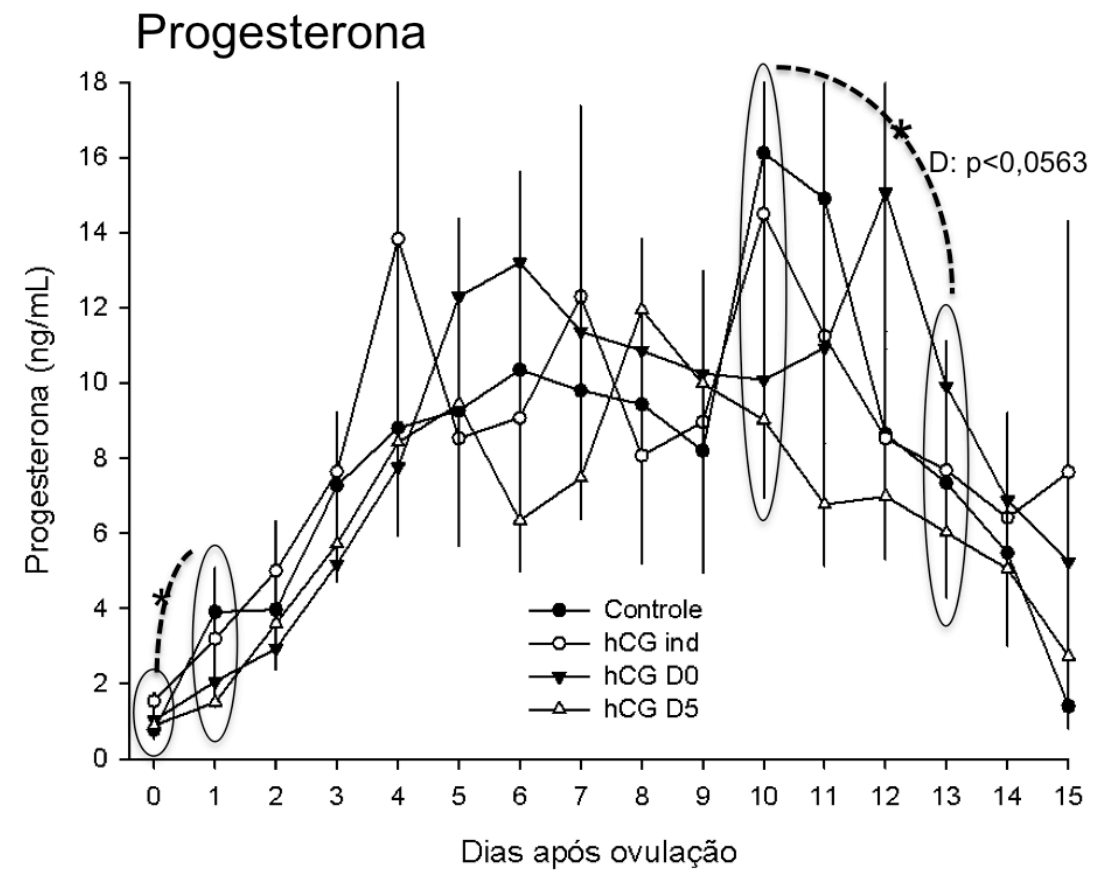

Nota: *Asterisco indica diferença estatística, $\mathrm{P}<0,05$

\subsection{RESULTADOS DO ESTUDO PRINCIPAL}

A primeira análise estatística realizada na segunda etapa do experimento foi com relação a comparação da concentração sérica de progesterona entre os animais que apresentaram ovulação simples e ovulação dupla, independente dos grupos aos quais pertenciam. 0 motivo pelo qual houve a necessidade desta comparação foi que os animais teriam diferença na progesterona o que, consequentemente, poderia influenciar nas características analisadas e dois corpos lúteos distintos estariam presentes.

No experimento, doze animais foram utilizados, sendo que cada um teve quatro ciclos (um em cada grupo de tratamento), totalizando portanto 48 ciclos. Destes, cinco apresentaram dupla ovulação, sendo um animal em três ciclos e dois animais em ciclos individuais. Estas duplas ovulações ocorreram nos dias 1, 2, 3, 6 e 8 pós ovulação.

Apesar da análise de grupo não ter detectado diferença estatística, foi detectada interação de grupo e dia $(\mathrm{p}<0,05)$. A progesterona aumentou a partir do dia 0 e o valor 
máximo foi atingido no dia 5 e permaneceu em platô até o dia 10. A partir de então, entre o dia 10 e 12 pós ovulação já foi notada uma queda significativa nas concentrações de progesterona $(\mathrm{p}<0,05)$ (Gráfico 12$)$.

Os animais com dupla ovulação apresentaram um aumento significativo nas concentrações séricas de progesterona entre os dias 0 e 2 pós ovulação $(P<0,05)$, atingindo valor máximo no dia 5 que manteve-se constante até o dia 12 . Somente entre os dias 12 e 15 que foi detectada uma queda significativa de progesterona nestes animais $(p<0,05)$. Entre os grupos foi encontrada tendência a diferença $(p<0,0599)$ no dia 2 e diferença significativa nas concentrações séricas de progesterona nos dias 3 $(\mathrm{p}<0,05), 4(\mathrm{p}<0,05)$ com o grupo com ovulações simples com maiores concentrações de progesterona e nos dias $13(\mathrm{p}<0,05)$ e $14(\mathrm{p}<0,05)$ uma maior concentração de progesterona no grupo com ovulação dupla (Gráfico 12).

Gráfico 12 - Média \pm erro padrão da concentração sérica de progesterona nas éguas com ovulação simples e dupla entre os dias 0 a 15 pós ovulação - Piracaia - 2012

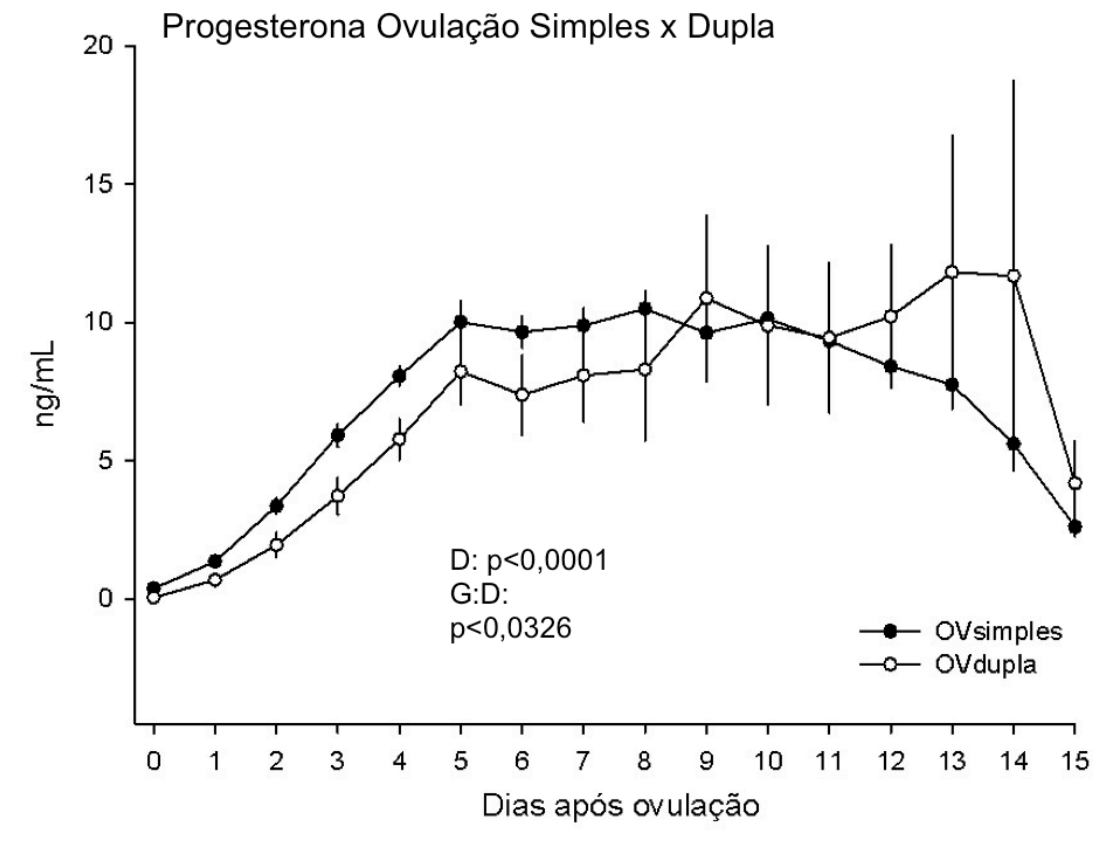

A morfoecogenicidade uterina não sofreu efeito de tratamento, somente foi detectada uma tendência a um efeito de dia. Pode ser notado pelo gráfico que no dia da ovulação, os animais apresentam edema endometrial, com morfoecogenicidade próxima a 4. Uma maior homogeneidade ocorreu ao longo dos dias 1 a 12 pós ovulação. Somente 
o grupo que recebeu hCG no dia 5 apresentou uma maior heterogeneidade na morfoecogenicidade uterina no dia 6 pós ovulação, e em seguida voltou a se comportar como os demais grupos, mas esta diferença não teve significado estatístico. A partir do dia 13 existe um aumento na heterogeneidade uterina, que retorna ao valor máximo no dia 15 em todos os grupos (Gráfico 13).

Gráfico 13 - Média \pm erro padrão do escore de morfoecogenicidade uterina das éguas nos diferentes tratamentos entre os dias 0 a 15 pós ovulação - Piracaia - 2012

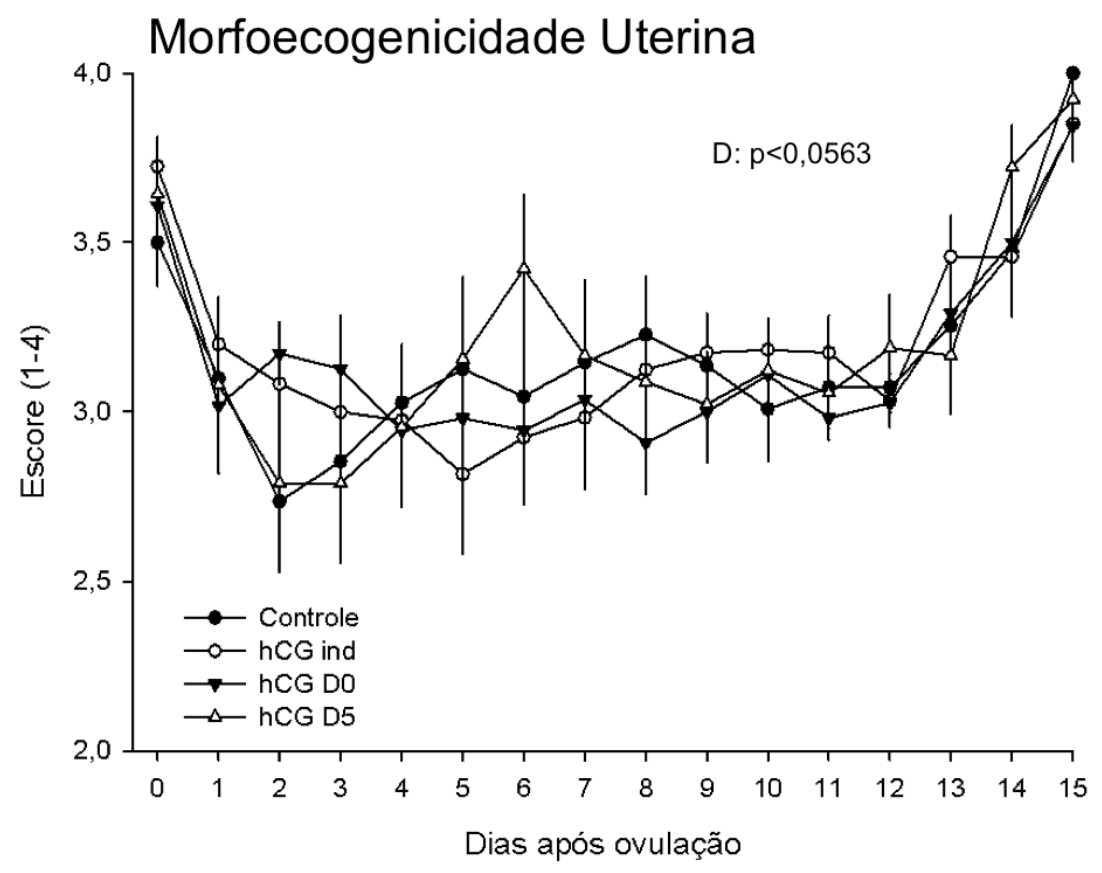


Gráfico 14 - Média \pm erro padrão do escore de tônus uterino das éguas nos diferentes tratamentos entre os dias 0 a 15 pós ovulação. - Piracaia - 2012

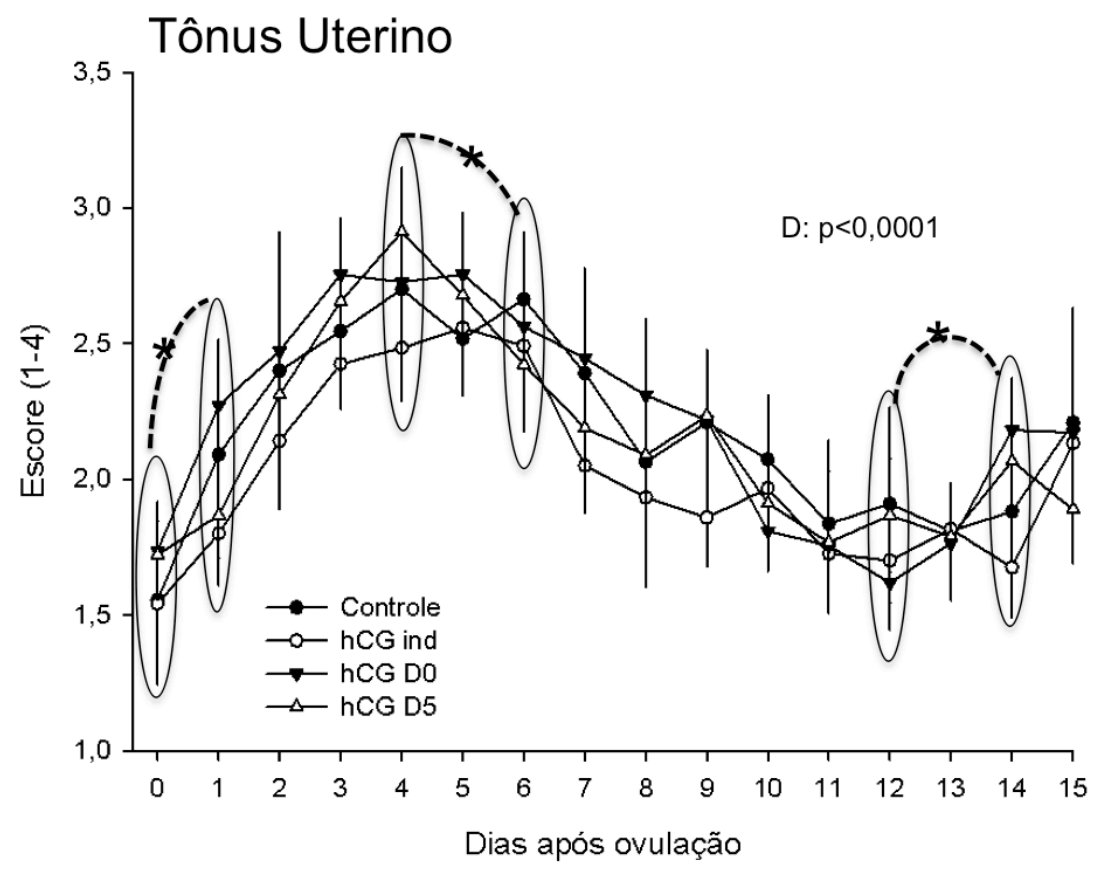

Quando avaliada a característica de tônus uterino, somente efeito de dia foi detectado e não de tratamento. No dia da ovulação, o tônus uterino se apresentava flácido. Um aumento significativo foi encontrado entre os dias 0 e 1, que se manteve até o dia 4, quando atingiu valor máximo. Uma diminuição estatisticamente significante foi encontrada entre os dias 4 e 6 pós ovulação, e continuo a diminuir até o dia 12. Entre os dias 12 e 14 um aumento significativo foi detectado, e este aumento se manteve no dia 15 (Gráfico 14). 
Gráfico 15 - Escore de tônus cervical das éguas nos diferentes tratamentos entre os dias 0 a 15 pós ovulação - Piracaia - 2012

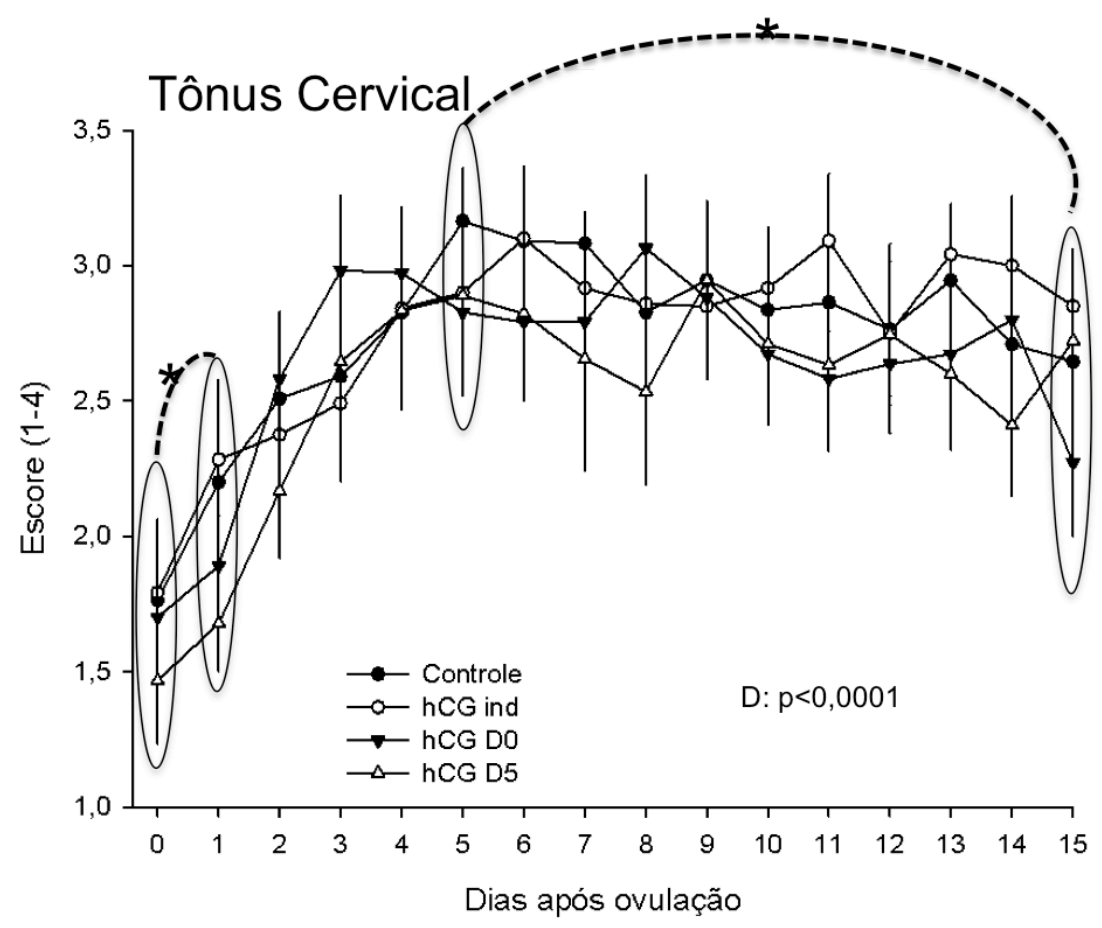

Nota: *Asterisco indica diferença estatística, $\mathrm{P}<0,05$

Não foi evidenciado efeito de tratamento na avaliação do tônus cervical, entretanto foi detectado efeito de dia $(\mathrm{p}<0,0001)$. 0 escore estava baixo (flácido) no dia 0 , já sofrendo um aumento no dia 1 pós ovulação $(\mathrm{p}<0,05)$. Este aumento foi contínuo até o dia 5, quando os valores mantiveram-se constantes. Somente foi detectado uma queda no tônus cervical quando comparados o dia 5 e o dia 15 pós ovulação $(p<0,05)$ (Gráfico 15). 
Gráfico 16 - Área do corpo lúteo das éguas nos diferentes tratamentos entre os dias 0 a 15 pós ovulação. (Asterisco indica diferença estatística, p<0,05) - Piracaia - 2012

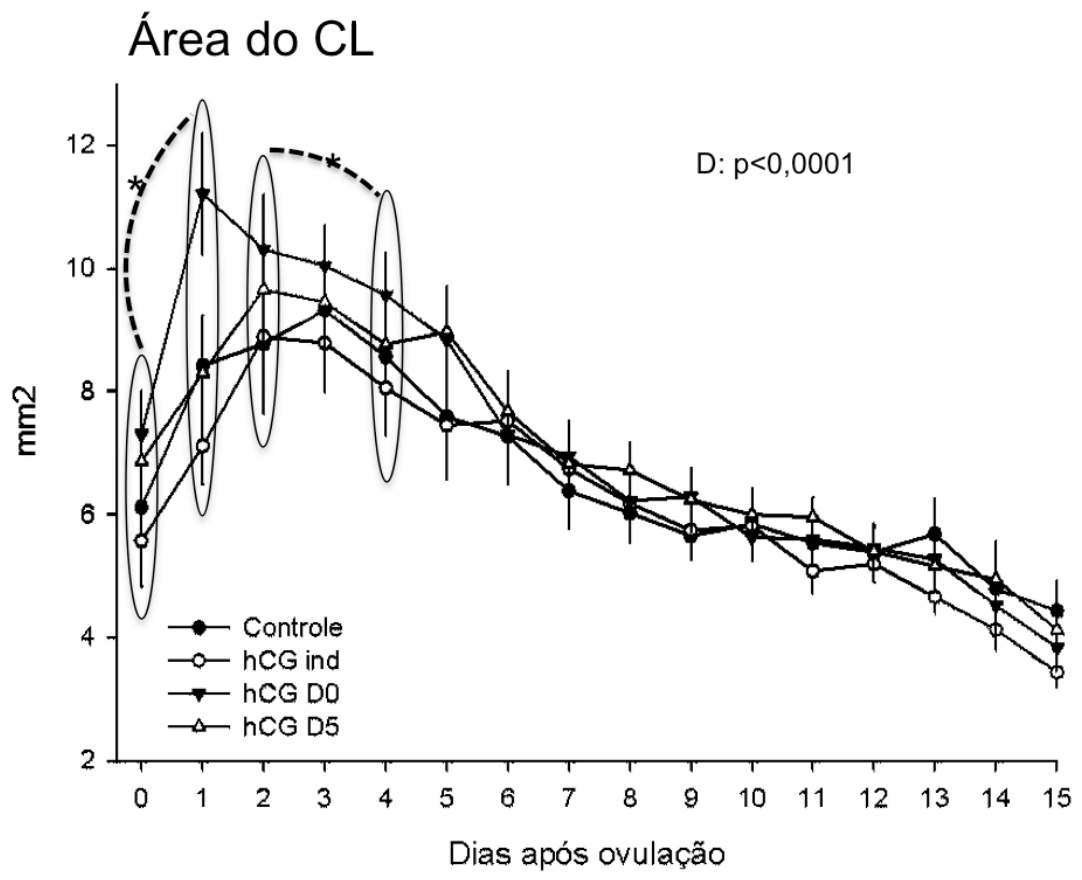

Nota: *Asterisco indica diferença estatística, $\mathrm{P}<0,05$

Efeito de dia ocorreu na área do corpo lúteo $(\mathrm{p}<0,0001)$, entretanto efeito de tratamento não foi detectado. A área sofreu um aumento entre os dias 0 e 1 pós ovulação significativo $(\mathrm{p}<0,0001)$. Entre os dias 3 e 4 uma diminuição foi encontrada $(p<0,05)$, e uma queda lenta nos valores até o dia 15 ocorreu a partir de então (Gráfico 16). 
Gráfico 17- Diâmetro do corpo lúteo das éguas nos diferentes tratamentos entre os dias 0 a 15 pós ovulação - Piracaia - 2012

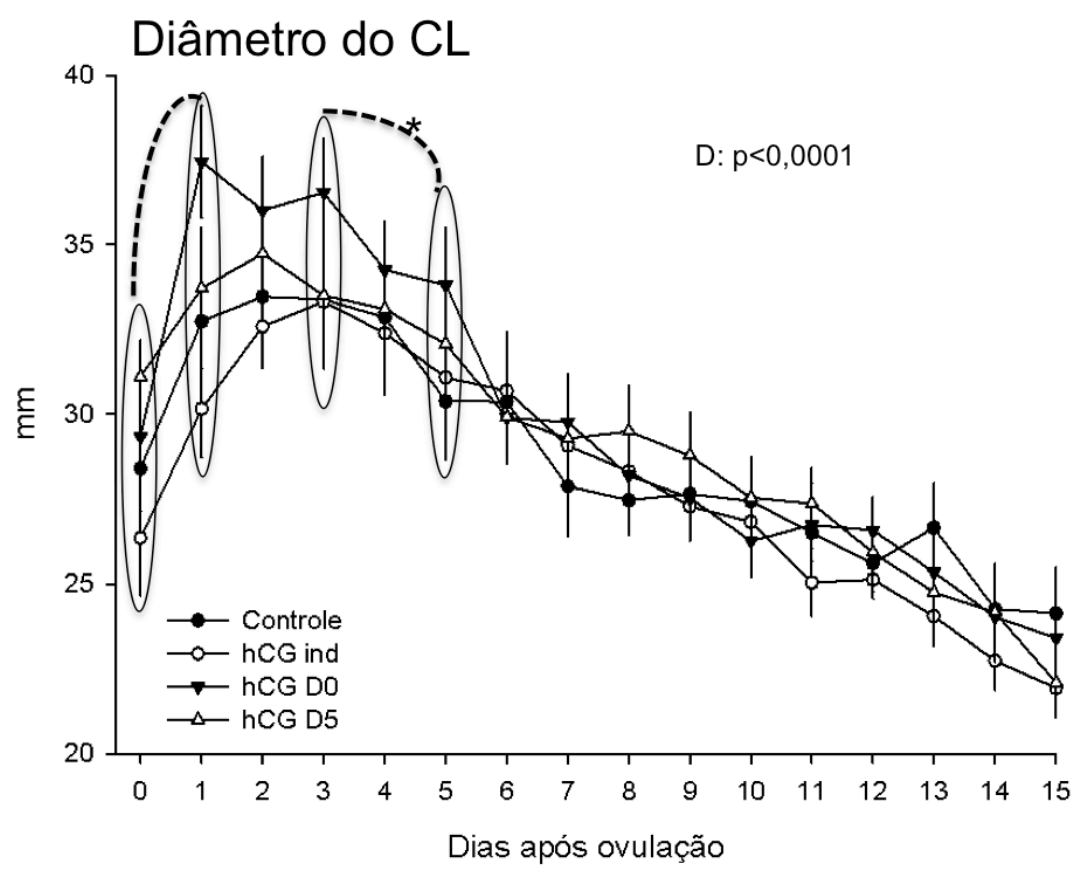

Nota: *Asterisco indica diferença estatística, $\mathrm{P}<0,05$

Com relação ao diâmetro do corpo lúteo, também não houve efeito de tratamento, somente de dia $(p<0,0001)$. Um aumento foi encontrado entre os dias 0 e 1 $(\mathrm{p}<0,0001)$. Entre os dias 3 e 5 inicia-se uma queda lenta $(\mathrm{p}<0,0004)$ que permanece até o dia 15 pós ovulação (Gráfico 17). 
Gráfico 18 - Porcentagem de vascularização do corpo lúteo das éguas nos diferentes tratamentos entre os dias 0 a 15 pós ovulação - Piracaia - 2012

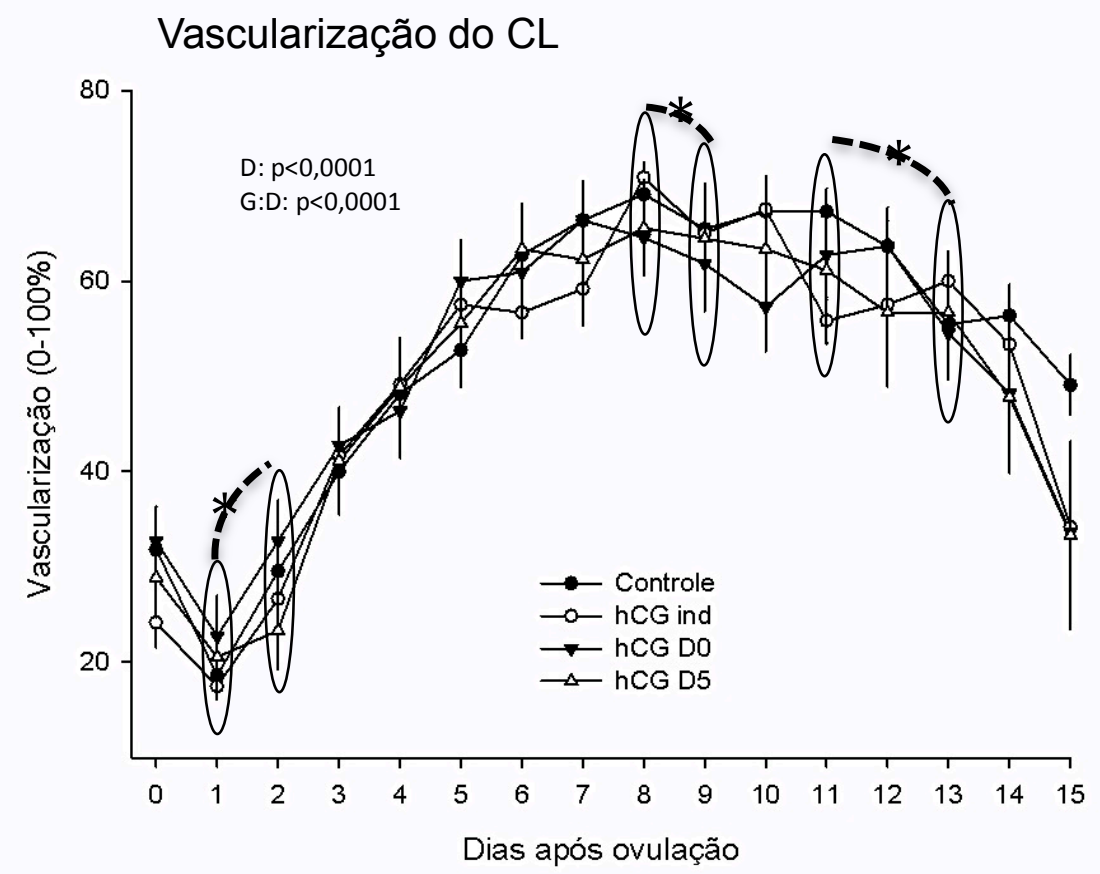

Nota: *Asterisco indica diferença estatística, $\mathrm{P}<0,05$

A vascularização do corpo lúteo também sofreu efeito de dia $(\mathrm{p}<0,0001)$, além de uma interação entre tratamento e dia também ter sido detectada $(p<0,0001)$. A vascularização iniciou com valores baixos e sofreu um aumento estatisticamente significante entre os dias 1 e $2(\mathrm{p}<0,05)$, e manteve este aumento até o dia 8. Já entre os dias 8 e 9 uma queda de vascularização ocorreu $(p<0,05)$, então a vascularização se manteve constante até o dia 11, quando uma segunda diminuição foi encontrada $(\mathrm{p}<0,05)$. A queda foi continua até o dia 15 pós ovulação (Gráfico 18). 
Gráfico 19 - Escore de vascularização do pedículo ovariano em éguas nos diferentes tratamentos entre os dias 0 a 15 pós ovulação - Piracaia - 2012

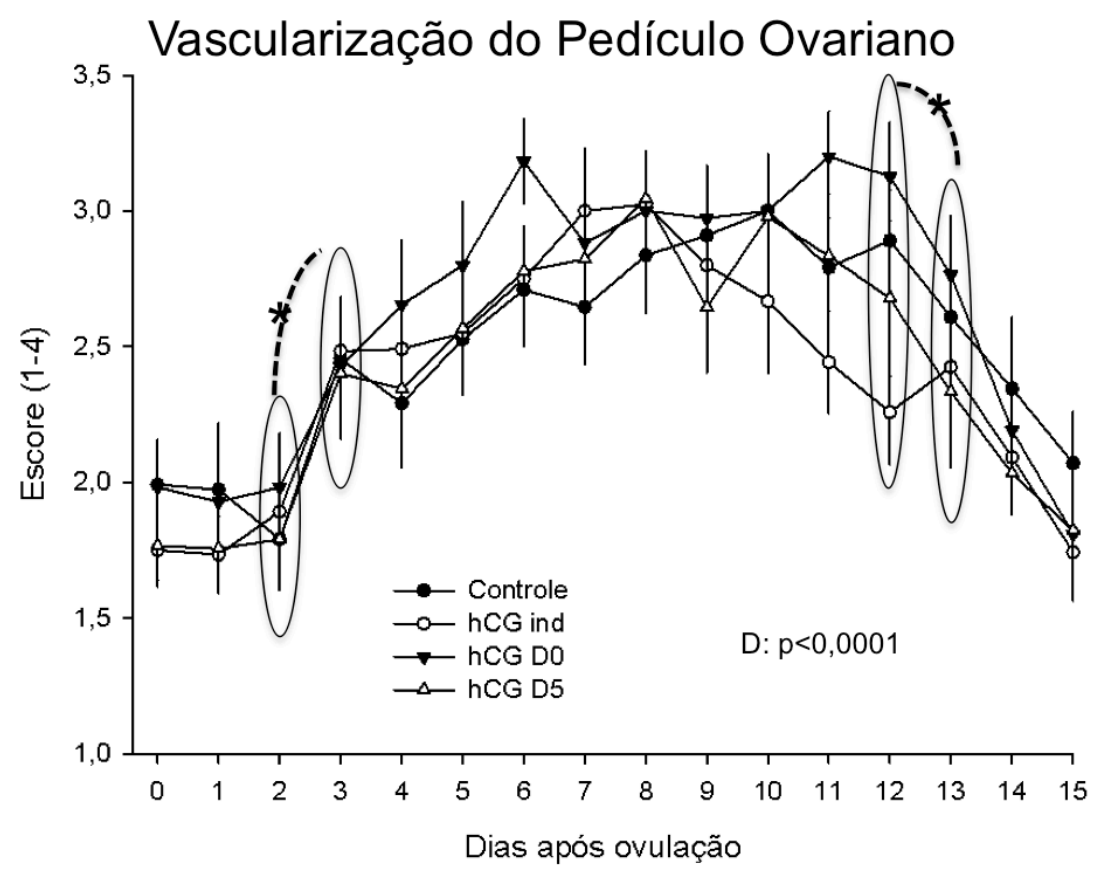

Nota: *Asterisco indica diferença estatística, $\mathrm{P}<0,05$

Avaliando-se a vascularização do pedículo ovariano, o efeito de dia foi encontrado $(\mathrm{p}<0,0001)$ mas não efeito de grupo. Valores baixos foram encontrados no dia da ovulação, até o dia 2. Um aumento aconteceu entre os dias 2 e 3 ( $\mathrm{p}<0,0001)$, chegando aos valores máximos no dia 6 que se mantiveram constantes até o dia 12. Uma queda foi detectada entre os dias 12 e 13, e continuo até o dia 15 pós ovulação (Gráfico 19). 
Gráfico 20 - Índice de resistência do pedículo ovariano em éguas nos diferentes tratamentos entre os dias 0 a 15 pós ovulação - Piracaia - 2012

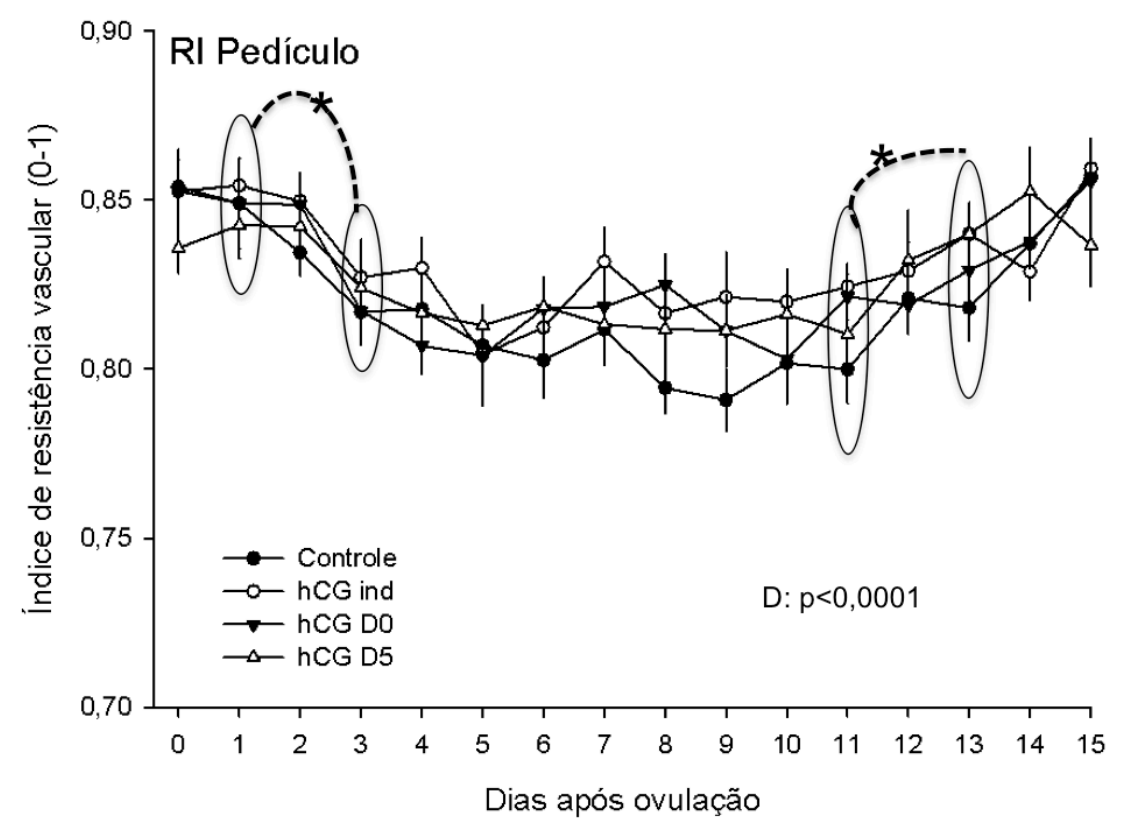

Nota: *Asterisco indica diferença estatística, $\mathrm{P}<0,05$

Da mesma forma, efeito de dia ocorreu $(\mathrm{p}<0,0001)$ e não de grupo no índice de resistência do pedículo ovariano. Os valores estavam altos no dia 0 e 1 pós ovulação. Entre os dias 1 e 3 houve uma diminuição nos valores estatisticamente significante $(\mathrm{p}<0,0001)$. Os valores foram estáveis até o dia 11, e sofreram um aumento entre o dia 11 e 13 pós ovulação, e esta elevação ocorreu até o dia 15 (Gráfico 20). 
Gráfico 21 - Escore de perfusão endometrial nas éguas nos diferentes tratamentos entre os dias 0 a 15 pós ovulação - Piracaia - 2012

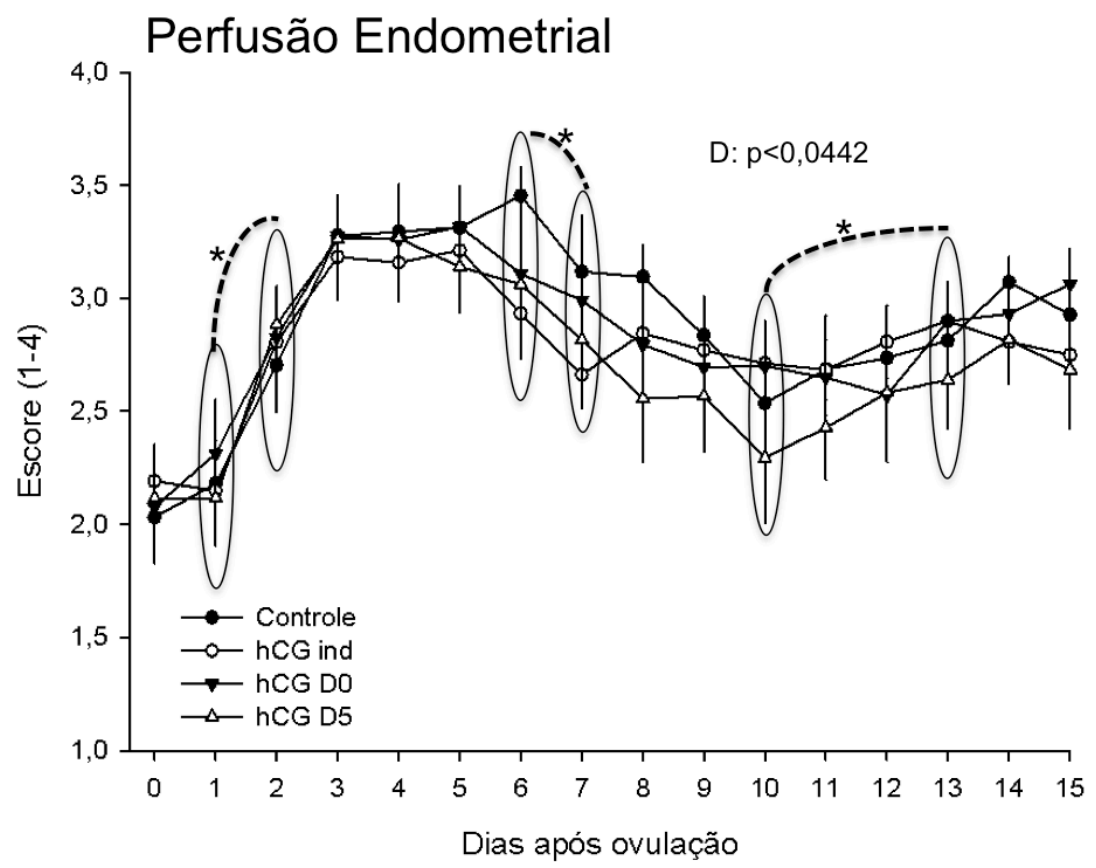

Nota: *Asterisco indica diferença estatística, $\mathrm{P}<0,05$

Uma análise estatística para avaliar se existia diferença entre a vascularização endometrial do corno ipisilateral e contralateral ao corpo lúteo foi realizada previamente e não detectou nenhuma diferença. Por este motivo, a média dos valores dos cornos foram calculadas para a realização da avaliação. Efeito de dia também foi encontrado na perfusão endometrial $(\mathrm{p}<0,05)$, enquanto não houve efeito de grupo. A perfusão estava baixa no dia da ovulação e no dia 1, no dia 2 ocorreu um aumento significativo $(\mathrm{p}<0,0001)$. Os valores mantiveram-se elevados até o dia 6. Entre o dia 6 e o dia 7 um decréscimo significativo $(\mathrm{p}<0,05)$ foi encontrado, se estendendo até o dia 10. Entre os dias 10 e 13, um novo aumento estatisticamente significativo foi detectado $(\mathrm{p}<0,05)$, que continuou até o dia 15 (Gráfico 21). 
Gráfico 22 - Escore de vascularização mesometrial nas éguas nos diferentes tratamentos entre os dias 0 a 15 pós ovulação - Piracaia - 2011

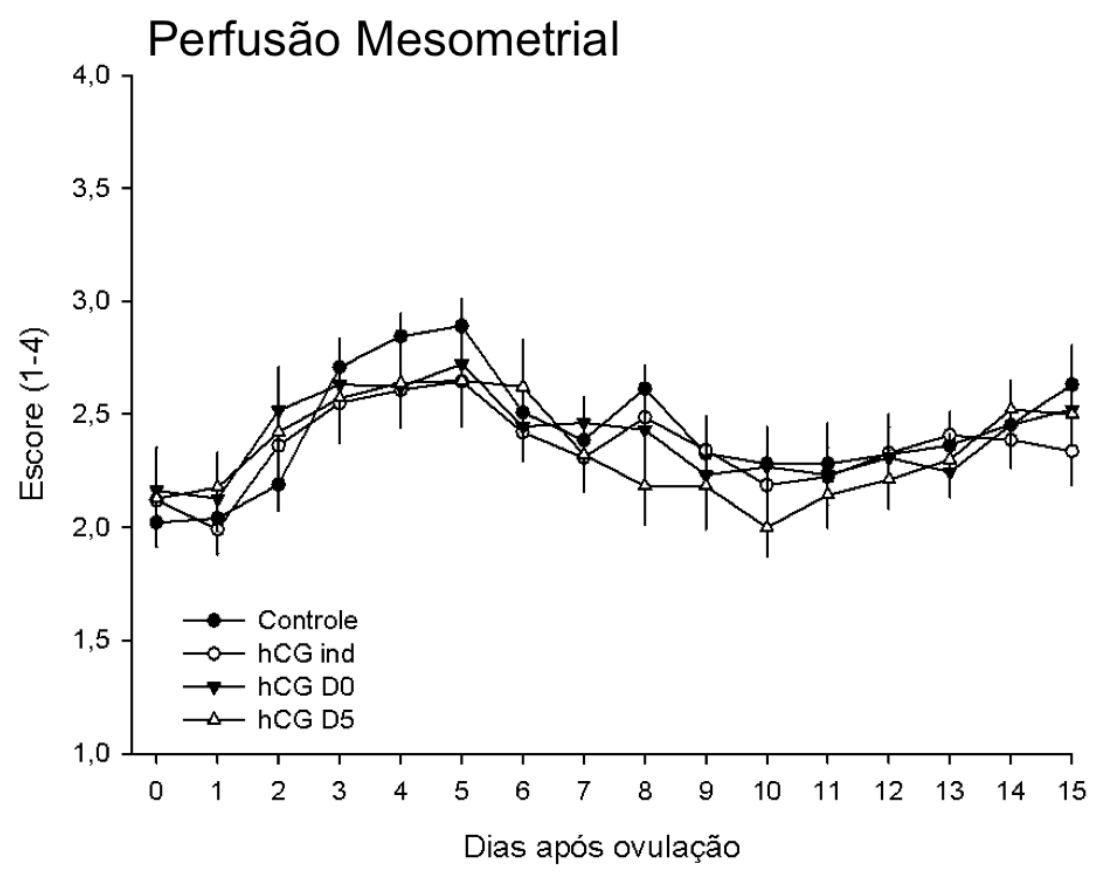

Nota: *Asterisco indica diferença estatística, $\mathrm{P}<0,05$

Da mesma forma que ocorreu para o endométrio, foi realizada a comparação entre mesométrio ipsilateral e contralateral. Também não foi encontrada diferença entre eles, e as médias obtidas foram utilizadas para posterior análise. Diferente entretanto do que detectou-se para o endométrio, para vascularização mesometrial não foi detectado efeito de dia e de grupo. Pode-se notar pelo gráfico que os valores estavam mais baixos entre os dias 0 e 1 pós ovulação, aumentaram até o dia 5, quando novamente começaram a decrescer até o dia 10. No dia 11 um aumento pode ser notado, continuando até o dia 15 (Gráfico 22). 
Gráfico 23 - Índice de resistência mesometrial nas éguas nos diferentes tratamentos entre os dias 0 a 15 pós ovulação - Piracaia - 2012

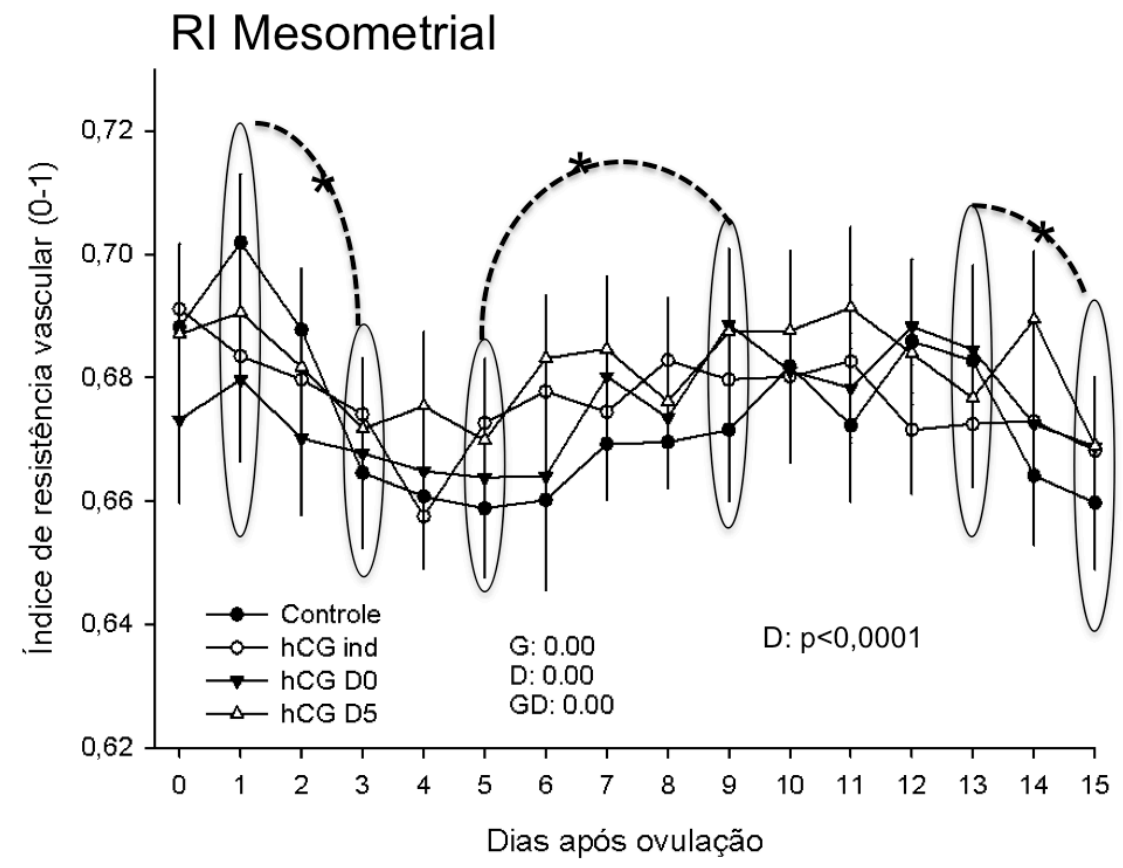

Nota: *Asterisco indica diferença estatística, $\mathrm{P}<0,05$

O índice de resistência do mesométrio foi mensurado, e a análise encontrou um efeito de dia $(\mathrm{p}<0,0001)$, mas não efeito de grupo. Entre os dias 0 e 1 o índice de resistência estava mais elevado, e entre os dias 1 e 3 uma queda com diferença estatística ocorreu $(\mathrm{p}<0,0091)$, permanecendo baixo até o dia 5 . Um aumento significativo ocorreu entre os dias 5 e $9(\mathrm{p}<0,05)$, persistindo nos mesmo valores até o dia 13. Um a diminuição aconteceu entre os dias 13 e 15, também com significado estatístico $(\mathrm{p}<0,05)$ (Gráfico 23). 
Gráfico 24 -- Concentração sérica de progesterona nas éguas nos diferentes tratamentos entre os dias 0 a 15 pós ovulação - Piracaia - 2012

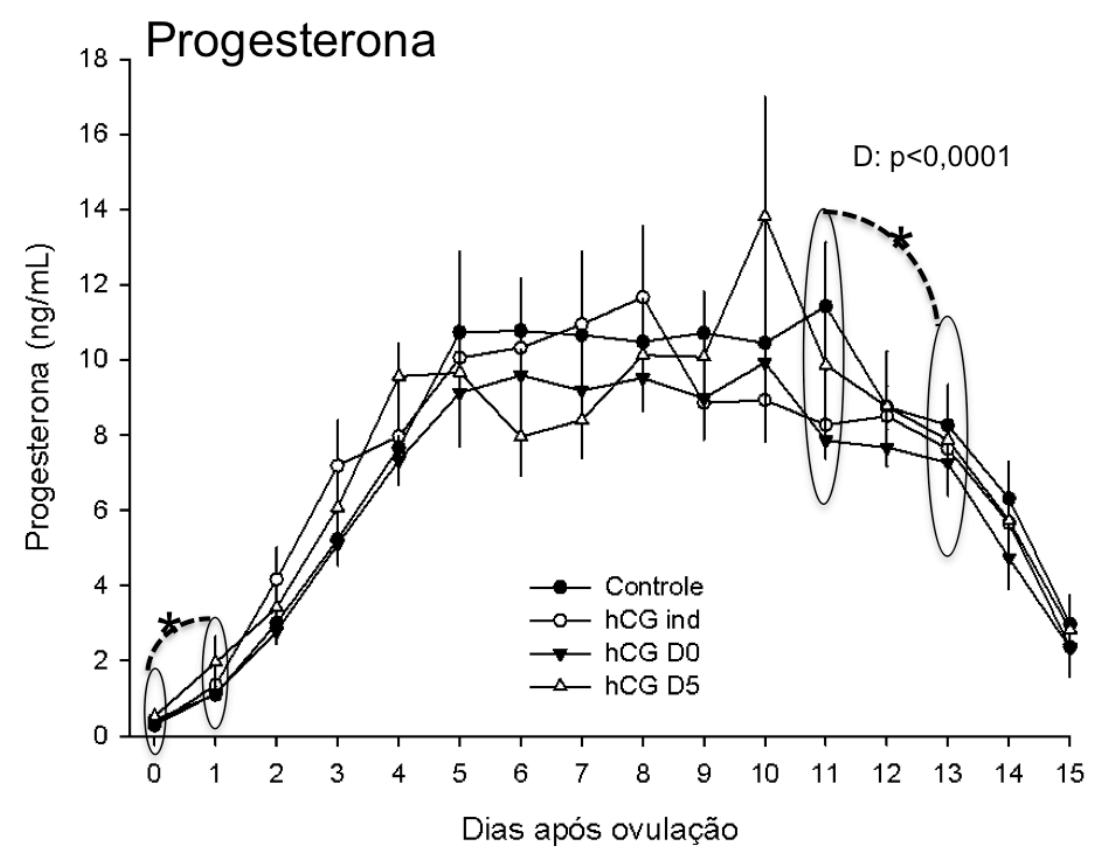

Nota: *Asterisco indica diferença estatística, $\mathrm{P}<0,05$

A concentração sérica de progesterona também não apresentou efeito de grupo, mas houve efeito de dia $(\mathrm{p}<0,0001)$. Já entre os dias 0 e 1 houve um aumento significativo de progesterona $(\mathrm{p}<0,0001)$, que continuou até o dia 5 . Entre os dias 5 e 11, os níveis mantiveram-se constantes. Entre os dias 12 e 14, uma diminuição da concentração de progesterona foi encontrada $(\mathrm{p}<0,05)$, que persistiu até o dia 15 (Gráfico 24). 
Díscussão 


\section{DISCUSSÃO}

Este é um trabalho inédito que relata os efeitos da utilização da hCG em éguas em três diferentes momentos do ciclo, indução de ovulação, no dia da ovulação e no dia 5 pós ovulação durante dezesseis dias consecutivos, desde a ovulação até o dia 15 pós ovulação. Neste experimento foram avaliados aspectos relacionados às características tônus uterino e cervical, morfoecogenicidade uterina, vascularização mesometrial, endometrial e luteal, além das características morfológicas e funcionais (concentração sérica de progesterona) do corpo lúteo. Com isso, pode ser avaliada de forma ampla o resultado dos tratamentos durante um período maior, desde a formação até o início da lise do corpo lúteo.

Esta abordagem abrangente vai trazer novos argumentos para o debate que existe na literatura e entre os veterinários envolvidos na área de reprodução acerca de tratamentos realizados nas éguas receptoras de embrião no dia da TE (FLEURY, 2004; SOUZA; 2006; KOBLISCHKE et al., 2010; HARTMANN, 2011; MCCUE et al., 2012) e nas éguas que vão levar suas gestações a termo no dia da cobertura e durante o diestro (PYCOCK; NEWCOMBE, 1996; NEWCOMBE; MARTINEZ; PETERS, 2001).

De acordo com Hartman (2011), este é o aspecto mais controverso da TE e a área mais pesquisada. Cada profissional utiliza um diferente protocolo de acordo com os custos e resultados benéficos que acreditam alcançar devido ao tratamento utilizado, abrangendo antiinflamatórios não esteroidais como o ácido meclofenâmico (KOBLISCHKE et al., 2008), vedaprofeno (KOBLISCHKE et al., 2010) e flunixin meglumine (HARTMAN, 2011); antibióticos (HARTMAN, 2011); hCG (HARTMAN, 2011; FLEURY, 2004), deslorelina (MCCUE et al., 2012) e progestágenos (DELUCA et al., 2011).

0 presente trabalho foi dividido em estudo preliminar, durante o qual um menor número de ciclos foi utilizado para que a técnica fosse aperfeiçoada. Durante o estudo principal, todas as avaliações, incluindo a utilização da técnica de Doppler espectral foram realizadas, e um maior número de ciclos foi avaliado.

Durante o estudo preliminar, nenhuma das éguas apresentou dupla ovulação. 0 total de ciclos avaliados durante o estudo principal foi 48 , sendo que cada um dos doze animais passou por todos os quatro tratamentos. Entretanto, como descrito na 
literatura, houve a ocorrência de duplas ovulações em alguns destes ciclos (GINTHER, 1992). Os dias pós ovulação nos quais as duplas ovulações ocorreram foram dia 1, 2, 3, 6 e 8. Destes 5 ciclos, 3 foram de um mesmo indivíduo e os outros dois de animais diferentes. Diversos trabalhos mostraram uma maior concentração circulante de progesterona nos animais com ovulação dupla (SQUIRES et al., 1987; GINTHER, 1992; NAGY et al., 2004), podendo a concentração maior encontrada nestes animais interferir com a análise do efeito do tratamento da hCG. Desta forma, a primeira análise que foi realizada nos resultados foi a comparação da concentração sérica de progesterona das éguas que apresentaram ovulação dupla ou simples com o intuito de decidir se elas seriam retiradas dos grupos aos quais pertenciam. Com a clara diferença demonstrada no comportamento dos perfis de progesterona, sofrendo uma queda dos níveis dois dias mais tarde nos animais que apresentaram ovulação dupla, e a interação significativa do grupo com o dia, determinou-se que estes animais seriam retirados dos seus respectivos grupos. Com isto, os grupos antes formados por 12 animais cada, permaneceram da seguinte forma: grupo controle com $n=11$, grupo hCG para induzir a ovulação com $n=12$, hCG no dia 0 com n=11 e hCG no dia 5 com $n=9$.

A primeira variável analisada no experimento foi a morfoecogenicidade uterina ao longo dos dias. Os níveis circulantes dos hormônios esteroides vão afetar a anatomia ultrassonográfica do útero (GINTHER, 1992) e por este motivo havia a hipótese de que se o tratamento com hCG pudesse aumentar as concentrações de progesterona, consequentemente poderia tornar o útero mais homogêneo. Este efeito seria benéfico uma vez que éguas receptoras com o útero com aspecto mais homogêneo apresentaram maiores taxas de prenhez comparadas com aquelas com aspecto mais heterogêneo (ALONSO, 2007).

Pelehach et al. (2002) demonstraram um efeito direto da progesterona na dissipação do edema endometrial. Entretanto, o tratamento com hCG não provocou nenhum efeito sobre esta característica, concordando com os resultados de Souza, (2006) nos quais os animais tratados com hCG para induzir a ovulação ou no dia 1 pós ovulação também não apresentaram alteração da morfoecogenicidade uterina. No estudo preliminar, houve efeito de dia, diferindo do estudo principal. Entretanto, apesar de não ter sido estatisticamente detectado efeito de dia, pode-se notar morfoecogenicidade heterogênea no dia da ovulação, sendo compatível com o baixo nível de progesterona circulante neste momento, semelhante ao encontrado no estudo 
preliminar. Em seguida, já no dia 1, o útero ficou com aspecto de diestro, perdendo o edema como esperado e acompanhando o aumento na concentração de progesterona, permanecendo desta forma até o dia 13, quando novamente houve uma maior heterogeneidade, voltando no dia 15 a valores semelhantes ao dia 0 . No dia 15, as concentrações de progesterona já estão retornando aos valores de estro, compatíveis com o acontecimento da luteólise (Al-ZI'ABI et al., 2002), justificando desta forma o aspecto novamente heterogêneo encontrado.

O tônus uterino foi avaliado pois existe uma relação positiva entre taxa de prenhez e tônus firme uterino, reportado por diversos autores. Alonso (2007) encontrou maior taxa de prenhez em receptoras que apresentavam maior tônus uterino no momento da TE comparado com animais com menor tônus, em concordância com Carnevale et al. (2001). McCue et al. (1999) encontraram uma relação entre tônus uterino bom e excelente com concentração plasmática de progesterona mais alta $(10 \pm$ 4,2 ng/mL) comparado com éguas com tônus uterino fraco e pobre $(6,5 \pm 4,3 \mathrm{ng} / \mathrm{mL})$. Já Alonso (2007) não detectou relação entre concentração sérica de progesterona e o tônus uterino das éguas nos dias 4 e 8 pós ovulação.

No presente trabalho foi hipotetizado que um efeito da hCG na concentração de progesterona poderia levar a um incremento no tônus uterino. Outra possibilidade que foi levantada seria de um efeito direto da hCG nos receptores extragonadais, como em humanos no qual a espessura do endométrio e receptividade uterina foram por ela influenciados (FILICORI et al., 2005). Contudo, no presente trabalho foi encontrada tendência de diferença no estudo preliminar de efeito de tratamento, entretanto não foi confirmado no estudo principal, sendo que a hCG nos diferentes momentos do ciclo não aumentou o tônus uterino. Provavelmente a diferença de resultado entre os dois estudos se deve ao pequeno número de animais utilizados e ao efeito individual, uma vez que cada animal somente foi submetido a um dos tratamentos na primeira etapa. Outra possível explicação poderia ser atribuída ao momento durante o qual o estudo preliminar foi realizado, já durante o outono. Apesar dos animais terem se mantido cíclicos após a realização do experimento, é descrita na literatura uma alteração hormonal e de ciclicidade neste período de transição de outono (KING, 2011). Alguns autores mostram um declínio do LH precoce, iniciando a partir de janeiro até abril, e um decréscimo ainda maior entre abril e julho (HART et al., 1984), e um efeito positivo no tônus pode ter ocorrido nos animais que receberam hCG. 
Caso o incremento de tônus uterino ocorresse, o tratamento de receptoras com hCG poderia levar a uma melhoria nas características uterinas destas, que refletiria em maior taxa de prenhez. Os resultados aqui encontrados também corroboram com os encontrados por Souza (2006), onde não foi encontrado efeito positivo da utilização da hCG para indução da ovulação ou no dia 1 pós ovulação no tônus uterino.

O tônus uterino sofreu efeito de dia nos dois estudos, sendo que no dia da ovulação os valores eram mínimos, representando útero flácido, uma vez que o edema do endométrio causa um afrouxamento dos tecidos, aumentado o diâmetro dos cornos, que se tornam achatados à palpação retal, como descrito na literatura (GINTHER, 1992). A primeira mudança detectada ao longo dos dias foi um aumento do tônus entre o dia 0 e 1 pós ovulação, provavelmente devido à ação dos níveis em ascensão de progesterona, provocando a dissipação do edema endometrial, conforme sugerido por Pelehach et al. (2002). Este aumento continuou até atingir valor máximo no dia 4 pós ovulação, diferindo dos resultados descritos por Bonafos et al. (1994) no qual o pico foi detectado no dia 6 pós ovulação. Entre o dia 4 e dia 6, ocorreu o início da diminuição do tônus uterino, chegando aos seus valores mínimos nos dias 12 e 13, diferente do valor mínimo do dia 10 do experimento de Bonafos et al. (1994). Entre os dias 12 e 14 um novo aumento foi detectado, que continuou até o dia 15. Bonafos et al. (1994) encontraram o pico no dia 13, contrário do tônus baixo encontrado no presente estudo neste mesmo momento. Uma provável explicação para a diminuição do tônus no dia 13 e aumento a partir deste momento seria a queda da concentração de progesterona no dia 12 e 13. A partir do dia 14, os níveis de progesterona estão baixos, entretanto ainda não estão em valores basais e são associados à elevação da concentração circulante de estrógeno pelo folículo dominante da onda que se tornará ovulatória, causando um aumento no tônus uterino, assemelhando-se ao aumento encontrado na gestação (HAYES; GINTHER, 1986).

0 tônus cervical também foi avaliado ao longo dos dias 0 a 15 pós ovulação, característica também relacionada aos resultados de prenhez nas éguas receptoras de embrião. De acordo com Carnevale et al. (2000), éguas com baixo tônus cervical não são desejáveis para receber um embrião, apresentando piores taxas de prenhez.

Os resultados encontrados neste estudo sugeriram que o tratamento das éguas com hCG nos diferentes momentos não causou mudança desta característica em relação às éguas controle. Todavia, Souza (2006) relatou um aumento da porcentagem de éguas 
com tônus cervical 3 e 4 (85,71\% dos animais) no dia 6 pós ovulação no grupo que recebeu 2500UI no dia 1 pós ovulação quando comparado com o grupo controle e grupo que recebeu hCG para induzir a ovulação (46,43\% em ambos). Este autor sugeriu um efeito positivo da aplicação da hCG, visto que é relatado que éguas com tônus uterino e cervical bom e excelente apresentam maiores taxas de prenhez (CARNEVALE et al., 2000; ALONSO, 2007). Possivelmente, o efeito encontrado por Souza (2006) pode ter sido causado por um efeito individual nos grupos, pois os animais não eram os mesmos em cada grupo. No experimento aqui relatado, os animais foram submetidos a todos os tratamentos, o que pode ter eliminado este efeito de indivíduo. Este achado reforça o resultado encontrado para tônus uterino, levando a crer que não exista influência do tônus do sistema reprodutivo da égua com o tratamento com hCG nos momentos aqui realizados.

A variação do tônus cervical é considerada importante e confiável como parâmetro das mudanças morfológicas do trato reprodutivo da égua, sendo útil para determinar o momento do ciclo no qual a égua se encontra (GINTHER, 1992). A maior flacidez é encontrada próximo à ocorrência da ovulação, da mesma forma que foi percebida no presente trabalho. Entre os dias 0 e 1 já houve um aumento do tônus, provavelmente causado pelo aumento nos níveis circulantes de progesterona. 0 valor máximo foi alcançado no dia 5 e somente no dia 15 começou novamente um declínio. Esta diminuição deve estar relacionada ao início do processo de luteólise, que causará a redução da progesterona e consequente flacidez novamente na cérvix.

Com o objetivo de avaliar o efeito da hCG sobre o CL, a área do CL foi mensurada utilizando a ferramenta disponível no aparelho de ultrassom. Normalmente, a área é pequena no dia da ovulação, aumenta até o dia 2, permanecendo alta até o dia 4, quando uma queda gradual é iniciada e continuada até o dia 15 pós ovulação (BERGFELT, ADAMS, 2007). Assim como as características avaliadas acima, a área também não apresentou alteração nos grupos submetidos aos tratamentos em relação ao grupo controle. Entretanto, ao observar o gráfico notamos uma maior área do CL no grupo que recebeu hCG no dia 0 entre os dias 1 e 4 pós ovulação, apesar de não haver significado estatístico. Alguns autores sugerem uma alteração na composição do corpo lúteo devido ao tratamento com hCG (HANSEL; BLAIR, 1996; FLEURY, 2004), no qual ocorre uma transformação de células luteais pequenas em grandes, que são as responsáveis pela maior parte da esteroidogênese do corpo lúteo, explicando a maior produção de 
progesterona. Considerando que as células luteais grandes no CL equino são cerca de 4 vezes maior que as células luteais pequenas (42 vs $11 \mu \mathrm{m}$, respectivamente) (WATSON; SERTICH, 1990), um aumento da área do CL seria esperado caso esta transformação ocorresse. Talvez uma mudança nas células tenha ocorrido, o que pode ter causado este aumento numérico da área do CL.

0 efeito de dia ocorreu, sendo que houve um aumento na área entre os dias da ovulação e dia 1, correspondendo à formação do corpo lúteo. Os maiores valores ocorreram entre os dias 2 e 3. Conforme o CL vai ser organizando, sua área já inicia uma diminuição entre os dias 2 e 4, que continua progressivamente até o dia 15, quando a menor área ao longo do período avaliado foi encontrada. Os dados aqui descritos estão portanto, de acordo com os relatos da literatura (BERGFET; ADAMS, 2007; BERGFELT; ADAMS, 2011). Esta diminuição tão precoce é paradoxal ao que ocorre na produção de progesterona (ARRUDA et al., 2001), cujos valores máximos só serão alcançados no dia 5 e se mantêm constantes até o dia 11 pós ovulação. Uma provável explicação para esta diminuição da área é a organização das células que compõem a estrutura luteal, apesar do aumento da vascularização e do número de células luteais grandes durante seu desenvolvimento.

Da mesma forma que a área, o diâmetro também não sofreu efeito do tratamento com hCG, assim como foi encontrado por FLEURY (2004). Apesar de novamente podermos notar entre os dias 1 e 5 pós ovulação um aumento numérico, da mesma forma como foi encontrada na área do CL. Reafirmando um possível efeito do tratamento com hCG no dia 0 na composição celular do CL, o que poderia ter acarretado este aumento do tamanho da estrutura. Ao longo do ciclo foi observado efeito de dia, sendo que entre o dia da ovulação e o dia 1 já houve um aumento detectado, sendo os maiores valores encontrados entre os dias 1 e 4, quando iniciou-se a queda constante até o dia 15. Estes resultados estão de acordo com os dados descritos na literatura, e acredita-se que estes valores maiores no início do desenvolvimento luteal (dia 0 a dia 5) sejam coincidentes com a maturação funcional da glândula, quando também são encontrados valores crescentes de progesterona circulante (BERGFELT; ADAMS, 2011). Os valores relativamente constantes entre os dias 5 a 10, apesar de menores do que os atingidos no início da sua formação, refletem a capacidade máxima funcional do CL, estando com máxima produção de progesterona. Ainda de acordo com os mesmos autores, a partir do dia 10 uma diminuição da área e diâmetro ocorrem em paralelo à 
diminuição da capacidade secretória do CL, resultado também demonstrado pelos valores encontrados nos animais do presente estudo.

Vale ressaltar que somente avaliar o diâmetro e área do CL de forma isolada não fornecem informação precisa a respeito de sua capacidade funcional ou idade, estes parâmetros devem estar associados à vascularização, ecogenicidade e produção de progesterona (BERGFELT; ADAMS, 2011).

Uma vez que foi detectado efeito da hCG sobre fluxo sanguíneo uterino em porcas (ZIECIK; STANCHEV; TILTON, 1986), ratas (RAO; ALSIP, 2001) e do sugerido efeito na angiogênese (TSAMPALAS et al., 2010), a vascularização do corpo lúteo ao longo dos dias foi acompanhada. Utilizou-se a porcentagem do CL que apresentava sinais Doppler, conforme descrito e validado por Ginther et al. (2007), mostrando a vantagem de ser uma avaliação em tempo real e com menor desconforto ao qual o animal é submetido durante a realização do exame. A hipótese proposta foi de um efeito direto da hCG na angiogênese do corpo lúteo, aumentando a vascularização e com isso haveria um maior aporte de substrato para a síntese de progesterona e para a distribuição sistêmica da progesterona produzida.

No estudo preliminar, houve efeito de tratamento, sendo que a vascularização do CL no grupo que recebeu hCG no dia 0 permaneceu elevada por um período maior, e foi estatisticamente maior comparado aos outros grupos nos dias 11, 13 e 15 pós ovulação. Porém, este resultado não se repetiu no estudo principal, sendo que a aplicação da hCG nos três momentos utilizados não causou nenhum efeito detectável na vascularização do corpo lúteo avaliado pela ultrassonografia Doppler. Assim como ocorreu com o tônus uterino, no qual uma tendência do efeito do tratamento foi detectada inicialmente e não foi aparente no estudo principal, o número reduzido de animais no estudo preliminar, e somente um tratamento por animal pode ter sido responsável por esta diferença.

Os corpos lúteos estudados apresentaram um aumento de vascularização durante o período de sua formação (dias 0 a 8), quando a máxima vascularização foi atingida, momento no qual também a máxima concentração de progesterona foi atingida. Bollwein et al. (2002) encontraram vascularização máxima ao redor do dia 6 pós ovulação, assim como Ginther et al. (2007), corroborando com os resultados encontrados no presente estudo durante o qual os valores máximos foram atingidos entre os dias 6 e 8 pós ovulação. Entre os dias 8 e 9 já foi notada uma diminuição na vascularização, anterior à queda da concentração plasmática de progesterona, 
reduzindo os valores ao longo dos dias, até o dia 15. Esta queda na vascularização provavelmente está associada com a redução na produção de progesterona. No período préluteolítico (14 dias pós ovulação) e luteolítico (entre dias 15 e 17 pós ovulação) (GINTHER et al., 2007) ocorre uma maior queda da vascularização luteal, compatível com estes momentos fisiológicos.

A vascularização do pedículo ovariano ipsilateral ao corpo lúteo foi avaliada de forma subjetiva, atribuindo-se um escore de 1 a 4 (1-mínimo e 4- máximo) e objetiva (índice de resistência). Os valores encontrados reforçaram os resultados da vascularização do corpo lúteo, visto que nos primeiros dias a vascularização estava baixa, com maior índice de resistência. Em seguida, a vascularização sofreu um aumento e houve uma queda no índice de resistência (permitindo maior aporte sanguíneo), que perpetuou durante os dias de máxima vascularização do corpo lúteo. Ou seja, maior aporte sanguíneo ao pedículo ovariano, maior chegada de sangue à estrutura luteal (BERGFELT; ADAMS, 2011). Em concordância com os resultados encontrados nas demais características avaliadas, e principalmente de vascularização do CL, não houve efeito do tratamento com hCG. A hCG utilizada para induzir a ovulação ou no dia da ovulação pode não ter causado efeito pois neste momento do ciclo dos animais, um nível alto de LH ocorre (ALEXANDER; IRVINE, 2011) porém um nível mínimo atingido deve ser suficiente para que ocorra a vascularização do CL normal, não causando qualquer efeito aditivo uma maior quantidade de LH ou hCG. Já no caso da hCG administrada no dia 5 pós ovulação, momento no qual espera-se que o LH esteja atingindo novamente níveis basais (EVANS; IRVINE, 1975), provavelmente ela não exerça efeito sobre a vascularização do CL pois esta já encontra-se estabelecida e provavelmente o efeito trófico do LH sobre o CL já deixou de existir.

Uma análise comparando a vascularização do corno ipsi e contralateral ao corpo lúteo foi realizada previamente para detectar possíveis diferenças. Porém, assim como anteriormente relatado por Silva et al. (2005), não foram encontradas diferenças nos valores para os diferentes cornos. Portanto, a vascularização endometrial foi considerada a média dos dois cornos. A vascularização endometrial foi outro aspecto analisado durante o experimento, pois existem relatos de influência direta da hCG em humanos na implantação e manutenção da gestação (HERMSTEINER et al., 1999), diminuição da atividade mioelétrica (ZIECIK; DERECKA-RESZKA; RZUCIDLO, 1992), redução das gap junctions miometriais (ETA, AMBRUS, RAO, 1994), provocando 
quiescência uterina e em ratos causou efeito direto vasodilatador e reduziu a resistência da artéria uterina e mesentérica (HERMSTEINER et al., 1999).

Nenhuma alteração no padrão de vascularização uterina ao longo dos dias entre os grupos foi encontrada, mais uma vez não sendo detectado o efeito da hCG, assim como relatado por Hendriks et al. (2006) que aplicaram hCG no dia 7 pós ovulação.

No dia da ovulação, a perfusão endometrial encontrava-se baixa, sendo o menor valor encontrado ao longo dos dias examinados. Um aumento significativo foi encontrado entre os dias 1 e 2, sendo os valores máximos entre os dias 3 a 5, em concordância com os resultados de Ignácio et al. (2012) e Bollwein et al. (1998), provavelmente ocorrendo de forma simultânea com a primeira onda folicular que se desenvolve no início do diestro, causando um aumento nos níveis circulantes de estrógeno (SILVA et al., 2005).

Curiosamente, Bollwein et al. (2004) administrou benzoato de estradiol no dia 5 e 10 pós ovulação para éguas e não encontrou um aumento do fluxo sanguíneo uterino nestes animais. 0 resultado encontrado contrariou a hipótese inicial dos autores e eles sugeriram que talvez a longa meia vida do estrógeno utilizado possa ter reduzido a resposta à terapia ou que o alto nível circulante de progesterona tenha inibido o efeito da administração de estrógeno.

Uma outra possibilidade que poderia explicar o aumento da perfusão endometrial neste período inicial do diestro seria um maior aporte sanguíneo para permitir a ação da progesterona sobre o útero, causando as alterações de tônus e secreção pelas glândulas endometriais em preparação para uma provável gestação. Como é conhecido, a expressão máxima de receptores de estrógeno e progesterona no endométrio da égua cíclica acontece durante o estro, pelo efeito do estrógeno. Com o aumento dos níveis de progesterona, a expressão de ambos os receptores diminui (HARTT et al., 2005), sugerindo talvez que o efeito da progesterona sobre seu receptor uterino seja de maior importância neste momento inicial. Entre os dias 5 e 6 é iniciado um declínio na perfusão endometrial, até o dia 10. Entre os dias 10 e 13, um novo aumento ocorreu na vascularização endometrial, até o dia 15 em todos os grupos, assim como encontrado na literatura (GINTHER, 2007).

O mesométrio foi avaliado utilizando-se a mensuração objetiva, com a medida do índice de resistência das artérias mesometriais, conforme demonstrado por Ferreira (2012), e subjetiva atribuindo-se os escores de 1 a 4 (mínimo e máximo, 
respectivamente) (GINTHER, 2007). As duas avaliações se comportaram de forma inversa, quando houve redução no índice de resistência, um aumento da perfusão mesometrial aconteceu, como esperado, o que valida a avaliação subjetiva realizada. $\mathrm{Ou}$ seja, a relação negativa entre RI e vascularização mesometrial concorda com resultados prévios (GINTHER; UTT, 2004; SILVA, et al., 2005; FERREIRA, 2012). Da mesma forma que ocorreu com a perfusão endometrial, houve um aumento (não estatístico) a partir do dia 2, com diminuição a partir do dia 5 até o dia 10, onde o valor foi o menor do período avaliado. Em seguida, um aumento novamente ocorreu, até o dia 15. Estes resultados concordantes entre o comportamento do fluxo sanguíneo tanto ao mesométrio como endométrio eram esperados, uma vez que a vascularização mesometrial é responsável pelo aporte sanguíneo ao útero (endométrio e miométrio). Com isto, novamente pode ser inferida a possibilidade de relação entre este aumento e a onda folicular que ocorre neste momento do ciclo estral (SILVA et al., 2005; IGNÁCIO et al., 2012).

Por fim, a avaliação da concentração sérica de progesterona foi analisada ao longo dos dias. A hipótese inicial seria de um aumento em relação ao grupo controle com a utilização do tratamento com hCG baseado nos resultados prévios encontrados por diferentes grupos. Fleury (2004) relatou uma maior concentração de progesterona no grupo que recebeu hCG no dia da TE em relação aos grupos controle, e tratados com norgestomet. Souza (2006) utilizaram hCG para induzir ovulação e no dia 1 pós ovulação e detectaram concentrações de progesterona nos dias 0 e 4 pós ovulação maiores estatisticamente do que o grupo controle, o que levou a crer em uma luteinização mais precoce durante a formação do CL. Kelly et al. (1988) aplicaram hCG nos dias 3, 4 e 5 após o estro que resultou em aumento das concentrações de progesterona até o dia 14.

Entretanto, não foi encontrado efeito do tratamento com hCG nos diferentes dias do ciclo estral sobre esta característica no presente estudo. Provavelmente este resultado encontrado se deve ao adequado nível de LH necessário para a formação do CL ter ocorrido e que a hCG aplicada não provocou nenhum efeito benéfico de alteração da formação, luteinização e secreção de progesterona pelo CL. Além disso, a falha primária da formação do CL, com uma inadequada vascularização, provocada por baixa concentração de LH, com consequente reduzida produção de progesterona não parecem ocorrer durante a estação ovulatória em éguas. 
No grupo que recebeu hCG para induzir a ovulação, pode-se sugerir que independente do nível ovulatório endógeno não ter sido ainda atingido, a dose aplicada foi suficiente e adequada para causar a ovulação do folículo e formação de um CL normal e funcional, como demonstrado por tamanho, vascularização e produção de progesterona normais como encontrado por Urquieta et al. (2009).

O grupo que recebeu hCG no dia da ovulação, provavelmente já apresentava os níveis fisiológicos crescentes de $\mathrm{LH}$, que foram responsáveis pela ocorrência natural da ovulação e da subsequente formação do CL. Similarmente ao grupo citado anteriormente, um nível adequado de LH causa o processo normal de luteinização e produz um CL normal, não havendo quaisquer efeito benéfico de aplicar a hCG com o objetivo de se ligar ao receptores de LH/hCG e melhorar o processo. Talvez, o efeito proposto por Fleury (2004) de alteração na composição celular do CL com a aplicação de hCG, aumentando o número de células luteais grandes por transformação das células luteais pequenas não deve ter ocorrido visto que nenhum efeito sobre as concentrações de progesterona foi encontrado.

Na literatura, é descrito um aumento do número de receptores de LH no corpo lúteo de 21 vezes entre os dias 1 e 14 pós ovulação juntamente com um aumento na afinidade destes receptores pelo LH em 5 vezes (ROSER; EVANS, 1983). Provavelmente permitindo que mesmo com os baixos níveis de LH presentes neste momento do ciclo, seu papel na regulação luteal seja desempenhado de forma adequada. Este fato também reforça a provável ineficácia de aplicar hCG neste momento, pois o efeito almejado já foi atingido com o LH endógeno em baixíssimas concentrações.

Outra hipótese possível para explicar a ausência de efeito da aplicação da hCG neste momento é que os receptores da família G, da qual o receptor de LH/hCG faz parte, tem como característica sofrer downregulation por estímulo agonista prolongado, sendo que ele é internalizado e posteriormente degradado por lisossomos (ASCOLI, 1984; GHINEA et al., 1992). Com isso, a hCG aplicada não causaria efeito por não haver receptores para se ligar.

A inadequada formação do CL durante a estação ovulatória não foi demonstrada nos trabalhos realizados, talvez explicando o motivo da ausência de efeito da aplicação da hCG na concentração de progesterona. Por outro lado, o desenvolvimento insuficiente luteal já foi reportado em associação à ovulações provocadas durante os períodos de transição ou anovulatórios, nos quais os níveis de LH eram menores do que durante o 
período ovulatório. Nestes casos, uma maior perda embrionária foi encontrada nos animais que estavam em inatividade ovariana ao início do tratamento com GnRH, associada à baixo LH e baixas concentrações de progesterona antecedendo 6 dias as perdas (GINTHER, 1992). Possivelmente o tratamento destes animais com hCG durante períodos fisiológicos nos quais os níveis de LH estão reduzidos seria positivo, causando a formação de um CL funcional e com duração normal, reduzindo as perdas embrionárias. Estudos nos quais a hCG fosse aplicada em ciclos nos quais um CL inadequado, resultante da ovulação com baixos níveis de LH e com baixa produção de progesterona poderiam trazer informações interessantes com relação ao resgate desta estrutura e taxa de prenhez nestes animais.

Com isso fica clara a diferença do efeito da utilização da hCG durante a fase luteal em equinos em relação às espécies bovina, bubalina, caprina e ovina, nas quais a hCG parece desempenhar uma mudança no CL e no perfil progesterônico (NEPHEW et al., 1994; SCHMITT et al., 1996; SAHARREA et al., 1998; SANTOS et al., 2001; KHAN et al., 2003; CAMPANILE et al., 2008; BEINDORFF et al., 2009).

Com os resultados encontrados em todos os aspectos avaliados no presente estudo, não foram encontrados efeitos provocados pela aplicação da hCG para induzir a ovulação, no dia da ovulação ou no dia 5 pós ovulação durante a estação ovulatória, nas características avaliadas durante este estudo, sendo contrários aos resultados encontrados por alguns autores (FLEURY, 2004; SOUZA, 2006) e em concordância com outros (HENDRIKS; COLENBRANDER; STOUT, 2006). Somente foi detectado um aumento não estatístico nas dimensões do CL (diâmetro e área), mas que não se refletiu em aumento nas concentrações séricas de progesterona nestes animais.

Além destes aspectos, não podemos deixar de mencionar a possibilidade da ação da hCG em outros locais ou mecanismos, tais como o mencionado efeito sobre os receptores de TSH (RIZZO et al., 2009) e os receptores extragonadais de hCG/LH reportados (PARAKARAINEN et al., 2007), que talvez poderiam apresentar efeitos em outras características que não foram avaliadas no presente estudo.

Portanto, levando-se em consideração resultados das pesquisas anteriores tanto em equinos como em outras espécies, novos estudos deveriam ser realizados para avaliar os efeitos da hCG em éguas. Talvez outros aspectos que não foram avaliados, tais como taxa de prenhez pudessem ter sido afetados pela aplicação da hCG. McCue et al. (2012) encontraram uma redução estatística na taxa de prenhez em éguas que 
receberam hCG no dia da TE comparado com o grupo controle ou tratado com $50 \mu \mathrm{g}$ de deslorelina, contrastando com o aumento numérico alcançado por Arruda e Fleury (2004).

Não pode deixar de ser evidenciada a complexidade da regulação do CL durante seu breve, porém fundamental período de existência no ovário da égua, na qual uma série de fatores estão envolvidos e sobre os quais muito pouco é sabido. O LH é apenas um dos envolvidos no seu processo de formação. O número de trabalhos sobre CL em equinos é infinitamente menor do que encontramos na literatura sobre bovinos, ovinos e ratos. Fica claro que um campo enorme de pesquisa existe e é necessário para entendermos melhor acerca desta importante estrutura essencial para a continuação da espécie.

Os resultados atualmente encontrados na literatura de taxa de prenhez pós TE sem a utilização de quaisquer tratamentos são satisfatórios (ALONSO, 2007; LOPES et al., 2011; MCCUE et al., 2012), apesar de muitos utilizarem tratamentos no dia da TE com o intuito de aumentar estas taxas (ALLEN, 2001; HARTTMAN, 2011). Podemos então sugerir maiores estudos nesta área de grande importância e pouco estudada para que estes tratamentos sejam feitos com base científica e não somente resultado empírico. 


\section{Conclusões}




\section{CONCLUSÕES}

- a hCG (2500UI, I.V.) aplicada para induzir a ovulação não provoca incremento no fluxo sanguíneo no útero e no corpo lúteo, não torna a morfoecogenicidade uterina mais homogênea, não causa aumento do tônus uterino e cervical e não afeta as concentrações de progesterona;

- a hCG (2500UI, I.V.) aplicada para no dia da ovulação não provoca incremento no fluxo sanguíneo no útero e no corpo lúteo, não torna a morfoecogenicidade uterina mais homogênea, não causa aumento do tônus uterino e cervical e não afeta as concentrações de progesterona;

- a hCG (2500UI, I.V.) aplicada no $5^{\circ}$ dia pós ovulação não provoca incremento no fluxo sanguíneo no útero e no corpo lúteo, não torna a morfoecogenicidade uterina mais homogênea, não causa aumento do tônus uterino e cervical e não afeta as concentrações de progesterona. 
Referências 


\section{REFERÊNCIAS}

ACOSTA, T. J.; BEG, M. A.; GINTHER, O. J. Aberrant blood flow area and plasma gonadotropin concentrations during the development of dominant-sized transitional anovulatory follicles in mares. Biology of Reproduction, v. 642, p. 637-642, 2004.

ACOSTA, T. J.; GASTAL, E. L.; GASTAL, M. O.; BEG, M. A.;GINTHER, O. J. Differential blood flow changes between the future dominant and subordinate follicles precede diameter changes during follicle selection in mares. Biology of Reproduction, v. 71, p. 502-507, 2004.

ACTON, S.; RIGOTTI, A.; LANDSCHULZ, K. T.; XU, S.; HOBBS, H. H.; AND KRIEGER, M. Identification of scavenger receptor SR-BI as a high-density lipoprotein receptor. Science, v. 271, p. 518-520, 1996.

ADAMS, G. P.; KASTELIC, J. P.; BERGFELT, D. R.; GINTHER, J. O. Effect of uterine inflammation and ultrasonically-detected uterine pathology on fertility in the mare. Journal of Reproduction Fertility, p. 445-454, 1987. Supplement, 35.

AGUILAR, J.; HANKS, M.; SHAW, D. J.; ELSE, R.; WATSON, E. Importance of using guarded techniques for the preparation of endometrial cytology smears in mares.

Theriogenology, v. 66, p. 423-430, 2006.

ALEXANDER, S. L.; IRVINE, C. H. G. Effect of graded doses of gonadotrophin-releasing hormone on serum LH concentrations in mares in various reproductive states: comparison with endogenously generated LH pulses. Journal of Endocrinology, v. 110, p. 19-26, 1986.

ALEXANDER, S. L.; IRVINE, C. H. G. GnRH secretion in the mare. Animal Reproduction Science, v. 42, n. 1-4, p. 173-180, 1996.

ALEXANDER, S. L.; IRVINE, C. H. G. FSH and LH. In: MCKINNON, A. O.; SQUIRES, E. L.; VAALA, W. E.; VARNER, D. D. Equine reproduction. 2. ed. [S.l.]: Wiley Blackwell, 2011. p. $1619-1630$.

AL-GUBORY, K. H.; GARREL, C.; FAURE, P.; SUGINO, N. Roles of antioxidants enzymes in corpus luteum rescue from reactive oxygen species-induced oxidative stress.

Reproductive Biomedical Online, v. 25, n. 6, p. 551-560, 2012.

ALLEN, A. W. Blood progesterone concentrations in pregnant and non-pregnant mares. Equine Veterinary Journal, v. 6, n. 2, p. 87-93, 1974.

ALLEN, W. E. The effect of human chorionic gonadotrophin and exogenous progesterone on luteal function during early pregnancy in pony mares. Animal Reproduction Science, v. 6, p. 223-228, 1983.

ALLEN, W. R. The physiology of early pregnancy in the mare. In: PROCEEDINGS OF THE AMERICAN ASSOCIATION OF EQUINE PRACTIOTIONERS, 46., 2000, San Antonio (TX). 
Proceedings... San Antonio (TX): American Association of Equine Practitioners, 2000. p. 338-354.

ALLEN, W. R. Luteal deficiency and embryo mortality in the mare. Reproduction in domestic animals, v. 36, n. 3-4, p. 121-31, 2001.

ALLEN, W. R.; WILSHER, S. A review of implantation and early placentation in the mare. Placenta, v. 30, p. 1005-1015, 2009.

ALMEIDA, F. Q. D.; SILVA, V. P. Revista Brasileira de Zootecnia Progresso científico em equideocultura na 1 a década do século XXI. Revista Brasileira de Zootecnia, v. 39, p. 119-129, 2010. Suplemento especial.

ALONSO, M. A. Efeito das características uterinas e dia do ciclo na taxa de prenhez e níveis séricos de progesterona em éguas candidatas à receptora de embrião. 2007, 72 f. Dissertação (Mestrado em Reprodução Animal)- Faculdade de Medicina Veterinária e Zootecnia, Universidade Estadual Paulista, Botucatu, 2007.

AL-ZI'ABI, M. O.; WATSON, E. D.; FRASER, H. M. Angiogenesis and vascular endothelial growth factor expression in the equine corpus luteum. Reproduction, v. 125, n. 2, p. 259-270, 2003.

AL-GUBORY, K. H.; GARREL, C.; FAURE, P.; SUGINO, N. Roles of antioxidant enzymes in corpus luteum rescue from reactive oxygen species-induced oxidative stress.

Reproductive Biomedicine Online, v. 25, n. 6, p. 551-560, 2012.

ARAUJO, R. R.; GINTHER, 0. J. Vascular perfusion of reproductive organs in pony mares and heifers during sedation with detomidine or xylazine. American Journal of Veterinary Medicine, v. 70, n. 1, p. 141-148, 2009.

ARRUDA, R. A.; FLEURY, P. D. C. Pregnancy rates and plasma progesterone concentrations in embryo recipient mares receiving hormone treatments. In: INTERNATIONAL SYMPOSIUM ON EQUINE EMBRYO TRANSFER, 6., 2004, Rio de Janeiro. Proceedings... Reino Unido, UK: Havemeyer Foundation, 2005. p. 95-96. Havemeyer Foundation Monograph Series no. 14.

ARRUDA, R. A.; VISINTIN, J. A.; FLEURY, J. J.; GARCIA, A. R.; MADUREIRA, E. H.; CELEGHINI, E. C. C.; NEVES NETO, J. R. Existem relações entre tamanho e morfoecogenicidade do corpo lúteo detectados pelo ultra-som e os teores de progesterona plasmática em receptoras de embriões equinos? Brazilian Journal of Veterinary Animal Science, v. 38, n. 5, p. 233-239, 2001.

AURICH, C. Reproductive cycles of horses. Animal Reproduction Science, v. 124, n. 3-4, p. 220-228, 2011.

BABER, R. J.; MCSWEENEY, M. B.; GILL, R. W.; PORTER, R. N.; PICKER, R. H.; WARREN, P. $\mathrm{S}$. Transvaginal pulsed Doppler ultrasound assessment of blood flow to the corpus luteum in IVF patients following embryo transfer. Brazilian Journal of Gynecology, v. 95, p. 1226-230, 1988. 
BAE, S.; WATSON, E. D. A light microscopic and ultrastructural study on the presence and location of oxytocin in the equine endometrium. Theriogenology, v. 60, n. 5, p. 909921, 2003.

BALL, B.A. Embryonic loss in mares: incidence, possible causes and diagnostic considerations. Veterinary Clinic of North America Equine Practice, v. 4, p. 263-290, 1988.

BARBACINI, S.; ZAVAGLIA, G.; GULDEN, P.; MARCHI, V.; NECCHI, D. Retrospective study on the efficacy of hCG in an equine artificial insemination programme using frozen semen. Equine Veterinary Education, v. 12, n. 6, p. 312-317, 2000.

BATRA, S. Effect of estrogen and progesterone treatment on calcium uptake by the myometrium and smooth muscle of the lower urinary tract. European Journal of Pharmacology, v. 127, p. 37-42, 1986.

BEG, M. A.; GINTHER, O. J. Follicle selection in cattle and horses: role of intrafollicular factors. Reproduction, v. 132, p. 365-377, 2006.

BEG, M. A.; BERGFELT, D. R. Corpus luteum development. In: MCKINNON, A. O.; SQUIRES, E. L.; VAALA, W. E.; VARNER, D. D. Equine reproduction. 2. ed. [S.l.]: Wiley Blackwell, 2011. p. 2009-2019.

BEINDORFF, N.; HONNENS, A.; PENNO, Y.; PAUL, V.; BOLLWEIN, H. Effects of human chorionic gonadotropin on luteal blood flow and progesterone secretion in cows and in vitro - microdialyzed corpora lutea. Theriogenology, v. 72, p. 528-534, 2009.

BERGFELT, D. R. Anatomy and physiology of the mare. In: SAMPER, J. C. Equine breeding management and artificial insemination. Philadelphia: W.B. Saunders Company, 2000. p. 165-177.

BERGFELT, D. R. Anatomy and physiology of the mare In: SAMPER, J. C. Equine breeding management and artificial insemination. 2. ed. St. Luis: Saunders, 2009. p. 113-131.

BERGFELT, D. R.; ADAMS, G. P. Luteal Development. In: MCKINNON, A. O.; SQUIRES, E. L.; VAALA, W. E.; VARNER, D. D. Equine reproduction. 2. ed. [S.l.]: Wiley Blackwell, 2011. p. 2055-2064.

BERGFELT, D. R.; ADAMS, G. P. Ovulation and corpus luteum development. In: SAMPER, J.; PYCOCK, J.; MCKINNON, A. O. Current therapy in equine reproduction. [S.l.]: Saunders, 2007. p. 1-13.

BERGFELT, D. R.; MANN, B. G.; SCHWARTZ, N. B.; GINTHER O. J. Circulating concentrations of immunoreactive inhibin and FSH during the estrous cycle of mares. Journal of Equine Veterinary Science, v. 11, p. 319-22, 1991.

BERGFELT, D. R.; WOODS, J. A.; GINTHER, O. J. Role of the embryonic vesicle and progesterone in embryonic loss in mares. Journal of Reproduction Fertility, v. 95, p. 339-347, 1992. 
BERISHA, B.; SCHAMS, D. Ovarian function in ruminants. Domestic Animal Endocrinology, v. 29, n. 2, p. 305-317, 2005.

BHAL, P. S.; PUGH, N. D.; GREGORY, L.; O'BRIEN, S.; SHAW, R. W. Perifollicular vascularity as a potential variable affecting outcome in stimulated intrauterine insemination treatment cycles: a study using transvaginal power Doppler. Human Reproduction, v. 16, p. 1682-1689, 2001.

BIELINSKA, M.; BOIME, I. Glycosylation of human chorionic gonadotropin in mRNAdependent cell-free extracts: post-translational processing of an asparigine-linked mannose rich oligosaccharide. In: PROCEEDINGS OF NATIONAL ACADEMY OF SCIENCES, 76., 1979. Proceedings ... : National academy of sciences, 1979. p. 12081212.

BISHOP, C. V.; STORMSHAK, F. Non-genomic actions of progesterone and estrogen in regulating reproductive events in domestic animals. The Veterinary Journal, v. 176, n. 3, p. 270-280, 2008.

BLANCHARD, T. L.; BRINSKO, S. P.; RIGBY, S. L. Effects of deslorelin or hCG administration on reproductive performance in first postpartum estrus mares. Theriogenology, v. 58, n. 1, p. 550-554, 2002.

BLANCHARD, T. L.; VARNER, D. D.; SCHUMACHER, J.; LOVE, C. C.; BRINSKO, S. P.; RIGBY, S. L. Manipulation of estrus in the mare. In: Manual of equine reproduction. 2. ed. [S.l.]: Mosby, 2003. p. 17-30.

BOERBOOM, D.; BROWN, K. A.; VAILLANCOURT, D.; POITRAS, P.; GOFF, A. K.; WATANABE, K.; DORE, M.; SIROIS, J. Expression of key prostaglandin synthases in equine endometrium during late diestrus and early pregnancy. Biology of Reproduction, v. 70, p. 391-399, 2004.

BOLLWEIN, H.; MAIERL, J.; MAYER, R.; STOLLA, R. Transrectal color doppler sonography of the A. uterina in cyclic mares. Theriogenology, v. 49, p. 1483-1488, 1998.

BOLLWEIN, H.; MAYER, R.; WEBER, F.; STOLLA, R. Luteal blood flow during the estrous cycle in mares. Theriogenology, v. 65, p. 2043-2051, 2002.

BOLLWEIN, H.; SOWADE, C.; STOLLA, R. The effect of semen extender, seminal plasma and raw semen on uterine and ovarian blood flow. Theriogenology, v. 60, p. 607-616, 2003.

BOLLWEIN, H. Transrectal Doppler sonography of uterine blood flow during early pregnancy in mares. Theriogenology, v.60, n. 4, p. 597-605, 2003.

BOLLWEIN, H. Transrectal Doppler sonography of uterine and umbilical blood flow during pregnancy in mares. Theriogenology, v. 6, n. 2-3, p. 499-509, 2004.

BONAFOS, L. D.; CARNEVALE, E. M.; SMITH, C. A.; GINTHER, O. J. Development of uterine tone in nonbred and pregnant mares. Theriogenology, v. 42, p. 1247-1255, 1994. 
BOTTARI, S. P.; VOKAER, A.; KAIVEZ, E.; LESCRAINER, J. P.; VAUQUELIN, G. P. Differential regulation of alpha-adrenergic receptor subclasses by gonadal steroids in human myometrium. The Journal of Clinical Endocrinology and Metabolism, v. 57, p. 937941, 1983.

BOURNE, T. H.; HAGSTROM, H.; HAHLIN, B.; JOSEFSSON, B.; GRANBERG, S.; HELLBERG, P. Ultrasound studies of vascular and morphological changes in the human corpus luteum during the menstrual cycle. Fertility and Sterility, v. 65, p. 753-758, 1996.

BOWEN-SHAUVER, J. M.; GIBORI, G. The corpus luteum of pregnancy. In: ADASHI, E. Y.; LEUNG, P. C. K. The ovary. New York: Raven Press. 2004. p. 201-232.

BRADECAMP, E. A. Synchronization of ovulation. In: MCKINNON, A. O.; SQUIRES, E. L.; VAALA, W. E.; VARNER, D. D. Equine Reproduction. 2. ed. [S.l.]: Wiley Blackwell, 2011.p. 1870-1878.

BRINSKO, S. P.; BALL, B. A.; MILLER, P. G.; THOMAS, P. G.; ELLINGTON, J. E. In vitro development of day 2 embryos obtained from young, fertile mares and aged, subfertile mares. Journal of Reproduction Fertility, v. 102, p. 371-378, 1994.

BROADLEY, C.; MENZIES, G. S.; BRAMLEY, T. A.; WATSON, E. D. Isolation of cell populations from the mare corpus luteum: comparison of mechanical and collagenase dissociation. Journal of Reproduction and Fertility, v. 102, p. 7-15, 1994.

CAMPANILE, G.; PALO, R. D.; NEGLIA, G.; VECCHIO, D.; GASPARRINI, B. Corpus luteum function and embryonic mortality in buffaloes treated with a GnRH agonist, hCG and progesterone. Theriogenology, v. 67, p. 1393-1398, 2007.

CAMPANILE, G.; VECCHIO, D.; DI PALO, R.; NEGLIA, G.; GASPARRINI, B.; PRANDI, A.; ZICARELLI, L.; D'OCCHIO, M. J. Delayed treatment with GnRH agonist, hCG and progesterone and reduced embryonic mortality in buffaloes. Theriogenology, v. 70, n. 1 , p. 1544-1549, 2008.

CANISSO, I. F.; BELTAIRE, K. A.; BEDFORD-GUAUS, S. J. Premature luteal regression in a pregnant mare and subsequent pregnancy maintenance with the use of oral altrenogest. Equine Veterinary Journal, v. 45, p. 97-100, 2013.

CARNEVALE, E. M.; RAMIREZ, R. J.; SQUIRES, E.L.; ALVARENGA, M. A.; VANDERWALL, D. K.; MCCUE, P. M. Factors affecting pregnancy rate and early embryonic death after equine embryo transfer. Theriogenology, v. 54, p. 965-979, 2000.

CARNEVALE, E. M. Oocyte transfer and gamete intrafallopian transfer in the mare. Animal Reproduction Science, v. 82-83, p. 617-624, 2004.

CARNEVALE, E. M. Mature oocyte collection. In: MCKINNON, A. O.; SQUIRES, E. L.; VAALA, W. E.; VARNER, D. D. Equine reproduction. 2. ed. [S.l.]: Wiley Blackwell, 2011. p. 2936-2940. 
CARR, B. R.; MACDONALD, P. C.; SIMPSON, E. R. The role of lipoproteins in the regulation of progesterone secretion by the corpus luteum. Fertility and Sterility, v. 38, p. 303311, 1982.

CHAPPELL, P. E.; LYDON, J. P.; CONNEELY, O. M.; O.MALLEY, B. W.; LEVINE, J. E. Endocrine effects in mice carrying a null mutation for the progesterone receptor gene. Endocrinology, v. 138, p. 4147-4152, 1997.

CHEW, B. P.; HOLPUCH, D. M.; O'FALLON, J. V. Relative concentrations of vitamin A and carotene in bovine and porcine plasma liver, corpora lutea and follicular fluid. Journal of Dairy Science, v. 67, p. 1316, 1984.

COLE, L. A. New discoveries in the biology and detection of human chorionic gonadotrophin. Reproductive Biology and Endocrinology, v. 7-8, 2008. doi:10.1186/1477-7827-7-8. Disponível em: <http://www.ncbi.nlm.nih.gov/pubmed/19171054>. Acesso em: 15/09/2012.

CROWELL-DAVIS, S. L. Sexual behavior of mares. Hormones and behavior, v. 52,n. 1, p. 12-17, 2007.

CUERVO-ARANGO, J.; DOMINGO-ORTIZ, R. Systemic treatment with high doses of flunixin-meglumine is able to block ovulation in mares by inducing hemorrhage and luteinisation of follicles. Theriogenology, v. 75, p. 707-714, 2011.

CUERVO-ARANGO, J.; NEWCOMBE, J. R. Repeatability of preovulatory follicular diameter and uterine edema pattern in two consecutive cycles in the mare and how they are influenced by ovulation inductors. Theriogenology, v. 69, p. 681-687, 2008.

DAELS, P. F.; HUGHES, J. P. The Normal Estrous Cycle. In: MCKINNON, A. O.; VOSS, J. L. Equine reproduction. Philadelphia: Lea \& Febiger, 1993. p. 121-132.

DAVIES MOREL, M. C.; NEWCOMBE, J. R. The efficacy of different hCG dose rates and the effect of hCG treatment on ovarian activity: ovulation, multiple ovulation, pregnancy, multiple pregnancy, synchrony of multiple ovulation in the mare. Animal Reproduction Science, v. 109, p. 89-99, 2008.

DAVIS, C. M.; DANEHOWER, S. C.; LAURENZA, A.; MOLONY, J. L. Identification of a role of the vitronectin receptor and protein kinase $C$ in the induction of endothelial cell vascular formation. Journal of Cell Biochemistry, v. 51, p. 206-218, 1993.

DAVISON, .A.; MCMANUS, C. J.; FITZGERALD, B. P. Gonadotropin response to naloxone in the mare: effect of the time of year and reproductive status. Biology of Reproduction, $v$. 59, p. 1195-1199, 1998.

DELUCA, C. A.; MCCUE, P. M.; PATTEN, M. L.; SQUIRES, E. L. Effect of a nonsurgical embryo transfer procedure and/or altrenogest therapy on endogenous progesterone concentration in mares. Journal of Equine Veterinary Science, v. 37, p. 51-62, 2011. 
DE RENSIS, F.; VALENTINI, R.; GORRIERI, F.; BOTTARELI, E.; LOPEZ-GATIUS, F. Inducing ovulation with hCG improves the fertility of dairy cows during the warm season. Theriogenology, v. 69, p. 1077-1082, 2008.

DHARMARAJAN, A. M.; BRUCE, N. W.; AND MEYER, G. T. Quantitative ultrastructural characteristics relating to transport between luteal cell cytoplasm and blood in the corpus luteum of the pregnant rat. American Journal of Anatomy, v. 172, p. 87-99, 1985.

DIAZ, T.; SCHMITT, E. J. P.; DE LA SOTA, R. L.; THATCHER, M. J.; THATCHER,W. W. Human chorionic gonadotropin-induced alterations in ovarian follicular dynamics during the estrous cycle of heifers. Journal of Animal Science, v. 76, p. 1929-1936, 1998.

DIAZ, F. J.; WILTBANK, M. C. Acquisition of luteolytic capacity : Changes in prostaglandin $\mathrm{F} 2 \mathrm{a}$ regulation of steroid hormone receptors and estradiol biosynthesis in pig corpora lutea. Biology of Reproduction, v. 70, p. 1333-1339, 2004.

DICKSON, S. E.; FRASER, M. Inhibition of early luteal angiogenesis by gonadotrophinreleasing hormone antagonist treatment in the primate. Journal of Clinical and Endocrinology and Metabolism, v. 85, p. 2339-2344, 2000.

DONADEU, F. X.; GINTHER, O. J. Effect of number and diameter of follicles on plasma concentration of inhibin and FSH in mares. Reproduction, v. 121, p. 897-903, 2001.

DONADEU, F. X.; WATSON, E. D. Seasonal changes in ovarian activity: lessons learnt from the horse. Animal Reproduction Science, v. 100, 225-242, 2007.

DOUGLAS R. H.; BURNS, P. J.; HERSHMAN, L. Physiological and commercial parameters for producing progeny from subfertile mares by embryo transfer. Equine Veterinary Journal, v. , p. 111-114, 1985, Supplemento 3.

ESPEY, L. L.; LIPNER, H. Ovulation. In: KNOBIL, E.; NEILL, J. D. The physiology of reproduction. 2. ed. New York: Raven Press, 1994. p. 725-780.

ESPEY, L. L.; BELLINGER, A. S.; HEALY, J. A. Ovulation: an inflammatory cascade of gene expression. In: ADASHI, E. Y.; LEUNG, P. C. K. The ovary. New York: Raven Press. 2004. p. $145-165$.

ETA, E.; AMBRUS, G.; RAO, C. V. Direct regulation of human myometrial contractions by human chorionic gonadotrophin. Journal of Clinical Endocrinology Metabolism, v. 79, p. 1582-1586, 1994.

EVANS, M. J.; GASTAL, E. L.; SILVA, L. A.; GASTAL, M. O.; KITSON, N. E.; ALEXANDER, S. L.; IRVINE, C. H. G. Plasma LH concentrations after administration of human chorionic gonadotropin to estrous mares. Animal Reproduction Science, v. 94, p. 191-194, 2006.

FARIN, C. E.; MOELLER, C. L.; SAWYER, H. R.; GAMBONI, F.; NISWENDER, G. D. Morphometric analysis of cell types in the ovine corpus luteum throughout the estrous cycle. Biology of Reproduction, v. 35, p. 1299-1308, 1986. 
FERREIRA-DIAS, G.; BRANCO, V.; ROBERTO DA COSTA, R.; PESSA, P.; ROBALO SILVA, S. Quantitative luteal cell composition and progesterone production in the mare. Reproduction in Domestic Animals, v. 37, n. 4, p. 231-232, 2002.

FERREIRA-DIAS, G.; BRAVO, P. P.; MATEUS, L. Microvascularization and angiogenic activity of equine corpora lutea throughout the estrous cycle. Domestic Animal Endocrinology, v. 30, p. 247-259, 2006.

FERREIRA-DIAS, G.; COSTA, A. S.; MATEUS, L.; KORZEKWA, A. J.; GALVÃO, A. Nitric oxide stimulates progesterone and prostaglandin $\mathrm{E} 2$ secretion as well as angiogenic activity in the equine corpus luteum. Reproduction in Domestic Animals, v. 40, n. 1, p. 1-9, 2011.

FERREIRA-DIAS, G.; COSTA, A. S.; MATEUS, L.; KORZEKWA, A.; REDMER, D. A.; SKARZYNSKI, D. J. Proliferative processes within the equine corpus luteum may depend on paracrine progesterone actions. Journal of Physiology and Pharmacology, v. 57, p. 139-151, 2006. Suplemento, 8.

FERREIRA-DIAS, G.; MATEUS, L.; COSTA, A. S.; SOLA, S. R. M.; RAMALHO, R. M.; CASTRO, R. E.; RODRIGUES, C. M. P. Progesterone and caspase- 3 activation in equine cyclic corpora lutea. Reproduction in Domestic Animals, v. 42, p. 380-386, 2007.

FERREIRA-DIAS, G.; SKARZYNSKI, D. J. Some aspects of regulation of luteal function and luteolysis in equine corpora lutea. Pferdeheilkunde, v. 24, p. 10-14, 2008.

FERREIRA, J. C. Influência as alterações degenerativas endometriais e da idade na hemodinâmica do trato reprodutivo de éguas após a inseminação artificial durante as fases iniciais desenvolvimento embrionário. 2012. 178 f. Tese (Doutorado em Medicina Veterinária)- Faculdade de Medicina Veterinária e Zootecnia, Universidade Estadual Paulista Júlio de Mesquita Neto, Botucatu, 2012.

FERREIRA, J. C.; GASTAL, E. L.; GINTHER, O. J. Uterine blood flow and perfusion in mares with uterine cysts: effect of the size of the cystic area and age. Reproduction, v. 135, p. 541-550, 2008.

FERREIRA, J. C.; MEIRA, C. Aplicação da ultrassonografia colorida Doppler em programas de transferência de embriões equinos. Ciência Rural, v. 41, n. 6, p. 1063-1069, 2011.

FILICORI, M.; FAZLEABAS, A.T.; HUHTANIEMI, I.; LICHT, P.; RAO, C. V.; TESARIK, J.; ZYGMUNT, M. Novel concepts of human chorionic gonadotropin : reproductive system interactions and potential in the society, Fertility and Sterility, v. 84, n. 2, p. 275-284, 2005.

FITZGERALD, B. P.; MCMANUS, C. J. Photoperiodic versus metabolic signals as determinants of seasonal anestrus in the mare. Biology of Reproduction, v. 63, p. 335$340,2000$.

FITZGERALD, B. P.; SCHMIDT, M. J. Absence of an association between melatonin and reproductive activity in mares during the nonbreeding season. Biology of

Reproduction Monograph, v. 1, p. 425-434, 1995. 
FLEURY, P. D. C. Taxa de prenhez e concentrações plasmáticas de progesterona em éguas receptoras de embrião submetidas a diferentes tratamentos hormonais no dia da inovulação. 2004. 66 f. Dissertação (Mestrado em Qualidade e Produtividade Animal)- Faculdade de Zootecnia e Engenharia de Alimentos, Universidade de São Paulo, Pirassununga, 2004.

FLEURY, P. D. C.; ALONSO, M. A.; SOUZA, F. A. C.; ANDRADE, A. F. C.; ARRUDA, R. P. Uso da gonadotrofina corionica humana (hCG) visando melhorar as características reprodutivas e fertilidade de receptoras de embriões equinos. Revista Brasileira de Reprodução Animal, Belo Horizonte, v. 31, n. 1, p. 27-31, 2007.

FRASER, H. M.; DICKSON, S. E.; LUNN, S. F.; WULFF, C.; MORRIS, K. D.; CARROLL, V. A.; BICKNELL, R. Suppression of luteal angiogenesis in the primate after neutralization of vascular endothelial growth factor. Endocrinology, v. 141, p. 995-1000, 2000.

FRASER, H. M.; LUNN, S. F. Regulation and manipulation of angiogenesis in the primate corpus luteum. Reproduction, v. 121, p. 355-362, 2001.

GALVÃO, A.; SKARZYNSKI, D. J.; ZÓSTEK, A.; SILVA, E.; TRAMONTANO, A.; MOLLO, A.; MATEUS, L.; FERREIRA-DIAS, G. Cytokines tumor necrosis factor-a and interferon participate in modulation of the equine corpus luteum autocrine and paracrine factors. Journal of Reproductive Immunology, v. 93, p. 28-37, 2012.

GARCIA, M. C.; FREEDMAN, L. J.; GINTHER, O. J. Interaction of seasonal and ovarian factors in the regulation of LH and FSH secretion in the mare. Journal of Reproduction and Fertility, v. , p. 103-11, 1979, Supplemento 27.

GARZA, F .J.; THOMPSON, D. L.; FRENCH, D. D.; WIEST, J. J.; GEORGE, R. L.; ASHLEY, K. B.; JONES, L. S.; MITCHELL, P. S.; MCNEILL, D. R. Active immunization of intact mares against gonadotropin-releasing hormone: differential effects on secretion of luteinizing hormone and follicle-stimulating hormone. Biology of Reproduction, v. 35, p. 347-352, 1986.

GASTAL, E. L. Ovulation: Part 2. Ultrasonographic morphology of the preovulatory follicle. In: MCKINNON, A. O.; SQUIRES, E. L.; VAALA, W. E.; VARNER, D. D. Equine Reproduction. 2. ed. [S.l.]: Wiley Blackwell, 2011. p. 2032-2054.

GASTAL, E. L.; GASTAL, M. O.; BEG, M. A.; GINTHER, O. J. Interrelationships among follicles during the common-growth phase of a follicular wave and capacity of individual follicles for dominance in mares. Reproduction, v. 128, p. 417-422, 2004.

GASTAL, E. L.; GASTAL, M. O.; BERGFELT, D. R.; GINTHER, O. J. Role of diameter differences among follicles in selection of a future dominant follicle in mares. Biology of Reproduction, v. 57, p. 1320-1327, 1997.

GASTAL, E. L.; GASTAL, M. O.; GINTHER, O. J. Relationship of changes in B-mode echotexture and colour-Doppler signals in the wall of the preovulatory follicle to changes in systemic oestradiol concentrations and the effects of human chorionic gonadotrophin in mares. Reproduction, v. 131, n. 4, p. 699-709, 2006. 
GASTAL, E. L.; GASTAL, M. O.; GINTHER, O. J. The suitability of echotexture characteristics of the follicular wall for identifying the optimal breeding day in mares. Theriogenology, v. 50, p. 1025-1038, 1998.

GASTAL, E. L.; GASTAL, M. O.; NOGUEIRA, G. P.; BERGFELT, D. R.; GINTHER, O. J. Temporal interrelationships among luteolysis, FSH and LH concentrations and follicle deviation in mares. Theriogenology, v. 53, p. 925-940, 2000.

GIANGRANDE, P. H.; MCDONNEL, D. P. The A and B isoforms of the human progesterone receptor: two functionally different transcription factors encoded by a single gene.

Recent Prog Hormonal Research, v. 54, p. 291-313, 1999.

GINTHER, O. J. Intrauterine movement of the early conceptus in barren and postpartum mares, Theriogenology, v. 21, p. 633-44, 1984.

GINTHER, O. J Folliculogenesis during the transitional period and early ovulatory season in mares. Journal of Reproduction and Fertility, v. 90, p. 311-320, 1990.

GINTHER, O. J. Reproductive biology of the mare: basic and applied aspects. 2. ed: CrossPlains, WI: Equiservices, 1992.

GINTHER, O. J. Major and minor follicular waves during the equine estrous cycle. Journal of Equine Veterinary Science, v. 13, p. 18-25, 1993.

GINTHER, O. J. Selection of the dominant follicle in cattle and horses. Animal Reproduction Science, v. 60-61, p. 61-79, 2000.

GINTHER, O. J. Ultrasonic imaging and animal reproduction: horses. Cross Plains, WI: Equiservices, 1995. Book 2.

GINTHER, O. J. Ultrasonic imaging and animal reproduction: color-doppler ultrasonography. Cross Plains, WI: Equiservices Publishing, 2007. Book 4.

GINTHER, O. J. The mare: A 1000-pound guinea pig for study of the ovulatory follicular wave in women, Theriogenology, v. 77, p. 818-828, 2012.

GINTHER, O. J.; ALMAMUN, M.; SHAHIDUZZAMAN, A. K.; BEG, M. A. Disruption of the periovulatory LH surge by a transient increase in circulating 17 beta-estradiol at the time of ovulation in mares. Animal Reproduction Science, v. 117, n. 1-2, p. 178-182, 2010.

GINTHER, O. J.; BEG, M. A. Dynamics of circulating progesterone concentrations before and during luteolysis: a comparison between cattle and horses. Biology of Reproduction, v. 86, n. 6, p. 1-12, 2012.

GINTHER, O. J.; BEG, M. A.; BERGFELT, D. R.; DONADEU, F. X.; KOT, K. Follicle selection in monovular species. Biology of Reproduction, v. 65, p. 638-47, 2001.

GINTHER, O. J.; BEG, M. A.; DONADEU, F. X.; BERGFELT, D. R. Mechanism of follicle deviation in monovular farm species. Animal Reproduction Science, v. 78, p. 239-257, 2003. 
GINTHER, O. J.; BEG, M. A.; GASTAL, E. L.; GASTAL, M. O.; COOPER, D. A. Treatment with human chorionic gonadotropin (hCG) for ovulation induction is associated with an immediate 17-estradiol decrease and a more rapid LH increase in mares. Animal Reproduction Science, v. 114, n. 1, p. 311-317, 2009.

GINTHER, O. J.; GARCIA, M. C.; BERGFELT, D. R.; LEITH, G. S.; SCRABA, S. T. Embryonic loss in mares: interovulatory pregnancy rate, length of intervals, and progesterone concentrations associated with loss during days 11 to 15 . Theriogenology, v. 24, n. 4, p. 409-417, 1985.

GINTHER, O. J.; BERGFELT, D. R. Associations between FSH concentrations and major and minor follicular waves in pregnant mares. Theriogenology, v. 38, p. 807-821, 1992.

GINTHER, O. J.; GASTAL, E. L.; GASTAL, M. O.; BEG, M. A. Critical role of insulin-like growth factor system in follicle selection and dominance in mares, Biology of Reproduction, v. 70, p. 1374-79, 2004b.

GINTHER, O. J.; GASTAL, E. L.; GASTAL, M. O.; BEG, M. A. Regulation of circulating gonadotropins by the negative effects of ovarian hormones in mares. Biology of Reproduction, v. 73, p. 315-323, 2005.

GINTHER, O. J.; GASTAL, E. L.; GASTAL, M. O.; BEG, M. A. Conversion of a viable preovulatory follicle into a hemorrhagic anovulatory follicle in mares. Animal Reproduction, v. 3, n. 1, p. 29-40, 2006b.

GINTHER, O. J.; GASTAL, E. L.; GASTAL, M. O.; BEG, M. A. Intrafollicular effect of IGF1 on development of follicle dominance in mares. Animal Reproduction Science, v. 105, p. 417-423, 2008.

GINTHER, O. J.; GASTAL, E. L.; GASTAL, M. O.; BERGFELT, D. R.; BAERWALD, A. R.; PIERSON, R. A. Comparative study of the dynamics of follicular waves in mares and women. Biology of Reproduction, v. 71, p. 1195-1201, 2004.

GINTHER, O. J.; GASTAL, E. L.; GASTAL, M. O.; UTT, M. D.; BEG, M. A. Luteal blood flow and progesterone production in mares. Animal Reproduction Science, v. 99, p. 213220, 2007a.

GINTHER, O. J.; UTT, M. D. Doppler ultrasound in equine reproduction: principles, techniques, and potential. Journal of Equine Veterinary Science, v. 24, n. 12, p. 516526, 2004.

GINTHER, O. J.; UTT, M. D.; BEG, M. A.; GASTAL, E. L.; GASTAL, M. O. Negative effect of estradiol on luteinizing hormone throughout the ovulatory luteinizing hormone surge in mares. Biology of Reproduction, v. 77, p. 543-50, 2007b.

GINTHER, O. J.; UTT, M. D.; BERGFELT, D. R.; BEG, M. A. Controlling interrelationships of progesterone/LH and estradiol/LH in mares. Animal Reproduction Science, v. 95, n. 12, p. 144-150, 2006a.

GLOCK, J. L.; BRUMSTED, J. R. Color flow pulsed Doppler ultrasound in diagnosing luteal phase defect. Fertility Sterility, v. 64, p. 500-504, 1995. 
GOMEZ-BRUNET, A. G.; SANTIAGO-MORENO, J.; MONTORO, V.; GARDE, J.; PONS, P.; GONZÁLEZ-BULNES, A.; LÓPEZ-SEBASTIÁN, A. Reproductive performance and progesterone secretion in estrus-induced Manchega ewes treated with hCG at the time of AI. Small Ruminant Research, v. 71, p. 117-122, 2007.

GREAVES, H. E.; KALARIOTES, V.; CLEAVER, B.D.; POTER, M. B.; SHARP, D. C. Effects of ovarian input on GnRH and LH secretion immediately postovulation in pony mares. Theriogenology, v. 55, p.1095-1106, 2001.

GREEN, J. M.; RAZ, T.; EPP, T.; CARLEY, S. D.; CARD, C. E. Relationships between uteroovarian parameters and the ovulatory response to human chorionic gonadotrophin (hCG) in mares. In: PROCEEDINGS OF THE AMERICAN ASSOCIATION OF EQUINE PRACTIONERS, 2007, Orlando, Florida. Proceedings... 2007. p.563-567.

GRIFFIN, P. G.; GINTHER, O. J. Dynamics of uterine diameter and endometrial morphology during the estrous cycle and early pregnancy in mares, Animal Reproduction Science, v. 25, n. 2, p. 133-142, 1991.

HAFEZ, E. S. E.; HAFEZ, B. Reproduction in Farm Animals. 7. ed. Philadelphia: Williams e Wilkins, 2000.

HAMBERGER, L.; DENNEFORS, B.; HAMBERGER, B.; JANSEN, P.O.; NILSON, L.; SJOGREN, A. Is vascular innervations a prerequisite for PG-induced luteolysis in the CL? In: SAMUELSSON, B.; RAMWELL, P. W.; PAOLETTI, R. Advances in prostaglandin and thromboxane research. New York: Raven Press, 1980. p.1365-1368.

HANSEL, W.; BLAIR, R. M. Bovine corpus luteum: a historic overview and implications for future research. Theriogenology, v. 45, p. 1267-1294, 1996.

HART, P. J.; SQUIRES, E. L.; IMEL, K. L.; NETT, T. M. Seasonal variation in hypothalamic content of gonadotropin-releasing hormone (GnRH), pituitary receptors for $\mathrm{GnRH}$, and pituitary content of luteinizing hormone and follicle-stimulating hormone in the mare. Biology of Reproduction, v. 30, n. 5, p. 1055-1062, 1984.

HARTT, L. S.; CARLING, S. J.; JOHNSON, G. A.; VANDERWALL, D. K.; OTT, T. L. Temporal and spatial associations of oestrogen receptor alpha and progesterone receptor in the endometrium of cyclic and early pregnant mares. Reproduction, v. 130, p. 241-250, 2005.

HAYES, K. E. N.; GINTHER, O. J. Role of progesterone and estrogen in development of uterine tone in mares. Theriogenology, v. 25, n. 4, p. 581-590, 1986.

HAYES, K. E. N.; PIERSON, R. A.; SCRABA, S. T.; GINTHER, O. J. Effects of oestrous cycle and season on ultrasonic uterine anatomy in mares. Theriogenology, v. 24, p. 465-477, 1985.

HEIDLER, B.; AURICH, J. E.; POHL, W.; AURICH, C. Body weight of mares and foals, estrous cycles and plasma glucose concentration in lactating and non-lactating Lipizzaner mares. Theriogenology, v. 61, p. 883-893, 2004. 
HENDRIKS, W. K.; COLENBRANDER, B.; STOUT, T. A. E. Effect of administering PGF $2 \alpha$ or hCG on day 7 after ovulation on ovarian, uterine and luteal blood flow in the mare. Animal Reproduction Science, v. 94, p. 223-225, 2006.

HENNEKE, D.R.; POTTER, G.D.; KREIDER, J.L.; YEATES, B.F. Relationships between condition score, physical measurements and body fat percentage in mares. Equine Veterinary Journal, v. 15, p.371-372, 1983.

HERMSTEINER, M.; ZOLTAN, D. R.; DOETSCH, J.; RASCHER, W.; KUENZEL, W. Human chorionic gonadotropin dilates uterine and mesenteric resistance arteries in pregnant and nonpregnant rats. Pflugers Archive, v. 439, p. 186-194, 1999.

HERSHMAN, J. M. Physiological and pathological aspects of the effect of human chorionic gonadotropin on the thyroid. Best Practice Research Endocrinology and Metabolism, v. 18, n. 2, p. 249-265, 2004.

HINRICHS K.; KENNEY, R. M.; SHARP, D. C. Differences in protein content of uterine fluid related to duration of progesterone treatment in ovariectomized mares used as embryo recipients. Equine Veterinary Journal, v. , p. 49-55, 1989. Supplemento, 8.

HOLTAN, D. W.; SQUIRES, E. L.; LAPIN, D. R.; GINTHER, O. J. Effect of ovariectomy on pregnancy in mares. Journal of Reproduction and Fertility, v. 27, p. 457-463, 1979, Supplemento 27.

HOYER, P. B.; NISWENDER, G. D. The regulation of steroidogenesis is different in the two types of ovine luteal cells. Canadian Journal of Physiology and Pharmacology, v. 63, p. 240-248, 1985.

HUGHES, J. P.; STABENFELDT, G. H.; EVANS, J. Clinical and endocrine aspects of the estrous cycle of the mare. In: PROCEEDINGS OF THE AMERICAN ASSOCIATION OF EQUINE PRACTIONERS, 1972. Proceedings... 1972. p. 119.

HWANG, J.; MENON, K. M. Characterization of low density and high density lipoprotein receptors in the rat corpus luteum and regulation by gonadotropin. Journal of Biological Chemistry, v. 258, p. 8020-8027, 1983.

IBGE. INSTITUTO BRASILEIRO DE GEOGRAFIA E ESTATÍSTICA. Produção da pecuária municipal. 2010. Disponível em: <http://www.ibge.gov.br/home/> Acesso em: $24 / 5 / 2010$.

IGNÁCIO, F. S.; CANESIN, H. S.; PANTOJA, J. C. F.; ROMANO, R. M.; NOVAES FILHO, L. F.; FERREIRA, J. C.; MEIRA, C. Uterine hemodynamic evaluation of the beginning of diestrous in mares, v. 32, n. 7, p. 06-407, 2012.

ILAN, N.; MAHOOTI, S.; MADRI, J. A. Distinct signal transduction pathways are utilized during the tube formation and survival phases of in vitro angiogenesis. Journal of Cell Science, v. 111, p. 3621-3631, 1998.

IRVINE, C. H. G.; SUTTON, P.; TURNER, J. E.; MENNICK, P. E. Changes in plasma progesterone concentrations from Days 17 to 42 of gestation in mares maintaining or losing pregnancy. Equine Veterinary Journal, v. 22, p. 104-106, 
1990.

IRVINE, C. H. G.; ALEXANDER, S. L.; MCKINNON, A. O. Reproductive hormone profiles in mares during the autumn transition as determined by collection of jugular blood at $6 \mathrm{~h}$ intervals throughout ovulatory and anovulatory cycles. Journal of Reproduction Fertility, v. 118, p. 101-109, 2000.

JABLONKA-SHARIFF, A.; GRAZUL-BILSKA, A. T.; REDMER, D. A.; REYNOLDS, L. P. Growth and cellular proliferation of ovine corpora lutea throughout the estrous cycle.

Endocrinology, v. 133, p. 1871-1879, 1993.

JAUNIAUX, E.; JURKOVIC, D.; DELOGNE-DESNOEK, J.; MEURIS, S. Influence of human chorionic gonadotrophin, oestradiol and progesterone on uteroplacental and corpus luteum blood flow in normal early pregnancy. Human Reproduction, v. 7, p .14671473, 1992.

KANITZ, W.; SCHNEIDER, F.; HOPPEN, H.-O.; UNGER, C.; NÜRNBERG, G.; BECKER, F. Pregnancy rates, LH and progesterone concentrations in mares treated with a GnRH agonist. Animal Reproduction Science, v. 97, n. 1-2, p. 55-62, 2007.

KASTELIC, J. P.; ADAMS, G. P.; GINTHER, O. J. Role of progesterone in mobility, fixation, orientation, and survival of the equine embryonic vesicle. Theriogenology, v. 27, n. 4, p. 655-663, 1987.

KAYNARD, A. H.; PERIMAN, L. M.; SIMARD, J.; MELNER, M. H. Ovarian 3 $\beta$-hydroxisteroid dehydrogenase and sulfated glycoprotein-2 gene expression are differentially regulated by the induction of ovulation, pseudopregnancy, and luteolysis in the immature rat. Endocrinology, v. 130, p. 2192-2200, 1992.

KEAY, S. D.; VATISH, M.; KARTERIS, E.; HILLHOUSE, E. W.; RANDEVA, H. S. The role of hCG in reproductive medicine. International Journal of Obstetrics and Gynecology, v. 111, p. 1218-1228, 2004.

KELLY C. M.; HOYER, P. B.; WISE, M. E. In-vitro and in-vivo responsiveness of the corpus luteum of the mare to gonadotrophin stimulation. Journal of Reproduction and Fertility, v. 84, p. 593-600, 1988.

KERBAN, A.; DORÉ, M.; SIROIS, J. Characterization of cellular and vascular changes in equine follicles during hCG-induced ovulation. Journal of Reproduction and Fertility, v. 117, n. 1, p. 115-123, 1999.

KERBLER, T. L.; BUHR, M. M.; JORDAN, L. T.; LESLIE, K. E.; WALTON, J. S. Relationship between maternal plasma progesterone concentration and interferon -tau synthesis by the conceptus in cattle. Theriogenology, v. 47, p. 703-714, 1997.

KHAN, T.; HASTIE, P. M.; BECK, N. F. G.; KHALID, M. hCG treatment on day of mating improves embryo viability and fertility in ewe lambs. Animal Reproduction Science, v. 76, n. 1, p. 81-89, 2003. 
KHORAMIAN, B.; FARZANEH, N.; GAROUSSI, M. T.; MOHRI, M. Research in veterinary science comparison of the effects of gonadotropin-releasing hormone, human chorionic gonadotropin or progesterone on pregnancy per artificial insemination in repeatbreeder dairy cows. Research in Veterinary Science, v. 90, n. 2, p. 312-315, 2011.

KING, S. S. Autumnal transition out of the breeding season. In: MCKINNON, A. O.; SQUIRES, E. L.; VAALA, W. E.; VARNER, D. D. Equine reproduction. 2. ed. [S.I.]: Wiley Blackwell, 2011. p. 1732-1753.

KING, S. S.; DILLE, E. A.; MARLO, T.; ROSER, J. F.; JONES, K. L. Ovarian prolactin activity: evidence of location and production. Animal Reproduction Science, v. 121S, p. S51S53, 2010.

KING, S.S.; NEQUIN, L. G.; DRAJE, S.; HEBNER, T. S. ROSER, J. F.; EVANS, J. W. Progesterone levels correlate with impending anestrus in the mare. Journal of Equine Veterinary Science, v. 8, p.109-11, 1988.

KING, S. S.; NEUMANN, K. R.; NEQUIN, L. G.; WEEDMAN, B. J. Time of onset and ovarian state prior to entry into winter anestrus Journal of Equine Veterinary Science, v. 13, p. 512-515, 1993.

KING, S. S.; ROSER, J. F.; JONES, K. L. Follicular fluid prolactin and the periovulatory prolactin surge in the mare. Journal of Equine Veterinary Science, v. 28, n. 8, p. 468472, 2008.

KNOWLES, J. E.; SQUIRES, E. L.; SHIDELER, R. K.; TARR, S. F.; NETT, T. M. Relationship of progesterone to early pregnancy loss in mares. Journal of Equine Veterinary Science, v. 13 , n. 9, p. 528-533, 1993.

KORZEKWA, A.; WOCLAWEK-POTOCKA, I.; OKUDA, K.; ACOSTA, T. J.; SKARZYNSKI, D. J. Nitric oxide in bovine corpus luteum: possible mechanisms of action in luteolysis.

Journal of Animal Science, v. 78, p. 233-242, 2007.

KOTWICA, J.; REKAWIECKI, R.; DURAS, M. Stimulatory influence of progesterone on its own synthesis in bovine corpus luteum. Bull Veterinary Institute Polawy, v. 48, p. 139$145,2004$.

KRISANS, S. K. Cell compartmentalization of cholesterol biosynthesis. Annals of the New York Academy of Sciences, v. 804, p. 142-164, 1996.

LAPTHORN, A. J.; HARRIS, D. C.; LITTLEJOHN, A.; LUSTBADER, J. W.; CANFIELD, R. E.; MACHIN, K. J.; MORGAN, F. J.; ISAACS, N. W. Crystal structure of human chorionic gonadotropin. Nature, v. 369, p. 455-461, 1994.

LEI, Z. M.; CHEGINI, N.; RAO, C. V. Quantitative cell composition of human and bovine corpora lutea from various reproductive states Biology of Reproduction, v. 44,p. 1148-1156, 1991.

LINDAHL, I. L. Detection of pregnancy in sheep by means of ultrasound. Nature, v. 212, p. 642-643, 1966. 
LOFSTEDT, R. M. Diestrus. In: MCKINNON, A. O.; SQUIRES, E. L.; VAALA, W. E.; VARNER, D. D. Equine reproduction. 2. ed. [S.l.]: Wiley Blackwell, 2011. p. 1728-1731.

LOFSTEDT, R. M.; IRELAND, W. P. Measuring sphere-like structures using transrectal ultrasonography. Veterinary Radiology Ultrasound, v. 41, p. 178-180, 2000.

LOPES, E. P.; SIQUEIRA, J. B.; PINHO, R. O.; GUIMARÃES, J. D.; ROCHA, A. N.; CARVALHO, G. R.; TORRES, C. A. A. Reproductive parameters in Mangalarga Marchador mares in a commercial embryo transfer programme. Reproduction in Domestic Animals, v. 46, p. 261-267, 2011.

LUNENFELD, B. Historical perspectives in gonadotrophin therapy. Human reproduction update, v. 10, n. 6, p. 453-467, 2004.

MACHADO, R.; BERGAMASCHI, M.A.C.M.; BARBOSA, R.T.; DE OLIVEIRA, C. A.; BINELLI, M. Ovarian function in Nelore (Bos taurus indicus) cows after post-ovulation hormonal treatment. Theriogenology, v. 69, p. 798-804, 2008.

MASLAR, I. A. P.; POWERS-CRADDOCK, R.; ANSBACHER, C. Decidual prolactin production by organ cultures of human endometrium: effects of continuous and intermittent progesterone treatment. Biology of Reproduction, v. 34, p. 741-750, 1986.

MCCUE, P. M.; ARNOLD, L. K.; CARROLL, B. S.; BURDEN, C. A.; GRAGG, D. M.; SCOFIELD, D. B.; HATZEL, J. N.; FERRIS, R. A. Administration of deslorelin or hCG at the time of embryo transfer: effect on pregnancy rates in recipient mares. Journal of Equine Veterinary Science, v. 32, n. 7, p. 415, 2012. Trabalho apresentado no $8^{\text {th }}$ International Symposium in Equine Embryo Transfer, 2012.

MCCUE, P.; HUDSON, J. J.; BRUEMMER, J. E.; SQUIRES, E. L. Efficacy of hCG at inducing ovulation: a new look at an old issue. In: ANNUAL CONVENTION OF THE AMERICAN ASSOCIATION OF EQUINE PRACTITIONERS, 50, 2004, Denver, Colorado, USA. Proceedings... 2004. p. 510-513.

MCCUE, P. M.; SCOGGIN, C. F.; LINDHOLM, A. R. G. Estrus. In: MCKINNON, A. O.; SQUIRES, E. L.; VAALA, W. E.; VARNER, D. D. Equine reproduction. 2. ed. [S.l.]: Wiley Blackwell, 2011. p. 1716-1727.

MCCUE, P. M.; VANDERWALL, D. K.; KEITH, S. L.; SQUIRES, E. L. Equine embryo transfer: influence of endogenous progesterone concentrations in recipients on pregnancy outcome. Theriogenology, v. , n. , p. 267, 1999.

MCKINNON, A. O.; MCCUE, P. M. Induction of ovulation. In: MCKINNON, A. O.; SQUIRES, E. L.; VAALA, W. E.; VARNER, D. D. Equine reproduction. 2. ed. [S.l.]: Wiley Blackwell, 2011. p. 1858-1869.

MEDAN, M. S.; ABD EL-ATY, A. M. Advances in ultrasonography and its application in domestic ruminants and other farm animals reproduction. Journal of Advanced Research, v. 1, p. 123-128, 2010. 
MEDEIROS, S. F. D.; NORMAN, R. J. Human choriogonadotrophin protein core and sugar branches heterogeneity: basic and clinical insights. Human Reproduction Update, $v$. 15, n. 1, p. 69-95, 2009.

MENON; K. M. J.; MENON, B. Structure, function and regulation of gonadotropin receptors - A perspective. Molecular and Cellular Endocrinology, v. 356, p. 88-97, 2012.

MICHEL, T. H.; ROSSDALE, P. D.; CASH, R. S. G. Efficacy of human chorionic gonadotrophin and gonadotrophin releasing hormone for hastening ovulation in Thoroughbred mares. Equine Veterinary Journal, v. 18, p. 438-442, 1986.

MIYAMOTO, A.; SHIRASUNA, K.; SASAHARA, K. Local regulation of corpus luteum development and regression in the cow : Impact of angiogenic and vasoactive factors. Domestic Animal Endocrinology, v. 37, p. 159-169, 2009.

MIYAZAKI, T.; TANAKA, M.; MIYAKOSHI, K.; MINEGISHI, K.; KASAI, K.; YOSHIMURA, Y. Power and Color Doppler ultrasonography for the evaluation of the vasculature of the human corpus luteum. Human Reproduction, v. 13, p. 2836-2841, 1998.

MORRESEY, P. R. How hormones work. In: MCKINNON, A. O.; SQUIRES, E. L.; VAALA, W. E.; VARNER, D. D. Equine reproduction. 2. ed. [S.l.]: Wiley Blackwell, 2011. p. 16011607.

MORRIS, L. H. A.; ALLEN, W. R. An overview of low dose insemination in the mare. Reproduction in Domestic Animals, v. 37, p. 206-210, 2002.

MORTENSEN, C. J.; ANTON, J.; KELLEY, D. E.; PRATT, S. E.; SMITH, R.; BIRRENKOTT, G.; VERNON, K. L. Uterine blood flow characteristics of exercised pregnant mares measured by Doppler ultrasonography. Animal Reproduction Science, v. 121S, p. 364-366, 2010.

MORTENSEN, C. J.; KELLEY, D. E.; WARREN, L. K. Supplemental l-arginine shortens gestation length and increases mare uterine blood flow before and after parturition. Journal of Equine Veterinary Science, v. 31, n. 9, p. 514-520, 2011.

MÜLLER, K.; ELLENBERGER, C.; SCHOON, H. Histomorphological and immunohistochemical study of angiogenesis and angiogenic factors in the ovary of the mare. Research in Veterinary Sciences, v. 1, p. 1-11, 2009.

MURPHY, B. D. Luteinization. In: ADASHI, E. Y.; LEUNG, P. C. K. The ovary. New York: Raven Press. 2004. p. 185-195.

NAGY, P.; GUILLAUME, D.; DAELS, P. Seasonality in mares. Animal Reproduction Science, v. 60-61, p. 245-262, 2000.

NAGY, P.; HUZENICZA, G.; REICZIGEL, J.; JUHÁSZ J.; KULCSÁR, M.; BÁVARY, K.; GUILLAUME, D. Factors affecting ma progesterone concentration and the retrospective determination of time of ovulation in cyclic mares. Theriogenology, v. 61, p. 203-214, 2004. 
NEELY, D. P.; KINDAHL, H.; STABENFELDT, G. H.; EDQVIST, L. E.; HUGHES, J. P. Prostaglandin release patterns in the mare. Physiological, pathophysiological and therapeutic responses. Journal of Reproduction and Fertility, v. 27, p. 181-191, 1979, Supplemento, 27.

NEPHEW, K. P.; CARDENAS, H.; MCCLURE, K. E.; OTT, T. L.; BAZER, F. W.; POPE, W. F. Effects of administration of human chorionic gonadotrophin or progesterone before maternal recognition of pregnancy on blastocyst development and pregnancy in sheep. Journal of Animal Science, v. 72, n. 2, p. 453-458, 1994.

NEQUIN, L. G.; KING, S. S.; ROSER, J. F.; SODERSTROM, B. L.; CARNEVALE, E. M.; NEUMANN, K. R. Uncoupling of the equine reproductive axes during transition into anoestrus. Journal of Reproduction Fertility, v. 56, p. 153-161, 2000, Supplemento, 56.

NEULEN, J.; RACZEK, S.; POGORZELSKI, M.; GRUNWALD, K.; YEO, T. K.; DVORAK, H. F.; WEICH, H. A.; BRECKWOLDT, M. Secretion of vascular endothelial growth factor/vascular permeability factor from human luteinized granulosa cells is human chorionic gonadotrophin dependent. Molecular Human Reproduction, v. 4, n. 3, p. 203-206, 1998.

NEULEN, J.; YAN, Z.; RACZEK, S.; WEINDEL, K.; KECK, C.; WEICH, H. A. Human chorionic gonadotropin-dependent expression of vascular endothelial growth factor/vascular permeability factor in human granulosa cells: importance in ovarian hyperstimulation syndrome. Journal of Clinical Endocrinology Metabolism, v. 80, p. 1967-1971, 1995.

NEWCOMBE, J. R. Observations on early pregnancy diagnosis and early embryonic loss in the mare. Irish Veterinary Journal, v. 50, p. 534-536, 1997.

NEWCOMBE, J. R. The follicle: practical aspects of follicle control. In: SAMPER, J.C.; PYCOCK, J. F.; MCKINNON, A. O. Current Therapy in Equine Reproduction. [S.l.], Saunders Elsevier, 2007, p. 14-21.

NEWCOMBE, J. R.; MARTINEZ, T. A.; PETERS, A. R. The effect of the gonadotropinreleasing hormone analog, buserelin, on pregnancy rates in horse and pony mares. Theriogenology, v. 55, p. 1619-1631, 2001.

NEWCOMBE, J. R.; WILSON, M. C. The effect of repeated treatment with human chorionic gonadotrophin to induce ovulation in mares. In: PROCEEDINGS OF THE BRITISH EQUINE VETERINARY ASSOCIATION, 46., 2007, Proceedings... Edinburgh, Scotland: British Equine Veterinary Association, 2007. p. 291.

NEWCOMBE, J. R. Human chorionic gonadotrophin. In: MCKINNON, A. O.; SQUIRES, E. L.; VAALA, W. E.; VARNER, D. D. Equine reproduction. 2. ed. [S.l.], Wiley Blackwell, 2011. p. 1804-10.

NISHIGAI, M.; KAMOMAE, H.; TANAKA, T.; KANEDA, Y. Improvement of pregnancy rate in Japanese Black cows by administration of hCG to recipients of transferred frozenthawed embryos. Theriogenology, v. 58, n. 8, p. 1597-606, 2002. 
NISWENDER, G. D. Molecular control of luteal secretion of progesterone. Reproduction, v. 123, p. 333-339, 2002.

NISWENDER, G. D.; JUENGEL, J. L.; SILVA, P. J.; ROLLYSON, M. K.; INTUSH, E. W. M. C. Mechanisms Controlling the Function and Life Span of the Corpus Luteum.

Physiological Reviews, v. 80, n. 1, p. 1-30, 2000.

NORJAVAARA, E.; OLOFSSON, J.; GAFVELS, M.; SELSTAM, G. Redistribution of ovarian blood flow after injection of human chorionic gonadotropin and luteinizing hormone in the adult pseudopregnant rat. Endocrinology, v. 120, p.107-114, 1987.

NORMAN, R. J.; BRANNSTROM, M. White cells and the ovary-incidental invaders or essential effectors? Journal of Endocrinology, v.140, p. 333-336, 1994.

PACCAMONTI, D. L.; RODRIGUEZ, H. F.; MYERS, M. W.; EILITS, B. E.; GODKE, R. A. Effects of $\mathrm{PGF}_{2 \alpha}$ or hCG administration during the early luteal phase on progesterone secretion in the mare. In: PROCEEDINGS OF AMERICAN ASSOCIATION OF EQUINE PRACTITIONERS, 37., 1991, Denver, Colorado. Proceedings... Colorado, American Association of Equine Practitioners, 1991. p. 151-9.

PADYKULA, H. A.; COLES, L. G.; OKULICZ, W. C.; RAPAPORT, S. I.; MCCRACKEN, J. A.; KING, N. W.; LONGCOPE, C.; KAISERMAN-ABRAMOF, I. R. The basalis of the primate endometrium: a bifunctional germinal compartment. Biology of Reproduction, v. 40, p. 681-690, 1989.

PALMER, E.; DRIANCOURT, M. A. Use of ultrasonic echography in equine gynecology, Theriogenology, v. 13, n. 3, p. 202-216, 1980.

PALMER, E.; DRIANCOURT, M. A. Some interactions of season of foaling, photoperiod and ovarian activity in the equine. Livestock Production Science, v. 10, p. 197-210, 1983.

PALMER, E.; GUILLAUME, D. Photoperiodism in the equine species-what is a long night? Animal Reproduction Science, v. 28, p. 21-30, 1992.

PANDEY, A. K.; GHUMAN, S. P. S.; DHALIWAL, G. S.; KUMAR, A.; AGARWAL, S. K. Impact of busereline acetate or hCG administration on day 12 post-ovulation on subsequent luteal profile and conception rates in buffalos (Bubalus bubalis). Animal Reproduction Science, v. 136, p. 260-267, 2013.

PAPA, F. O.; LOPES, M. D.; ALVARENGA, M. A.; MEIRA, C.; LUVIZOTTI, M. C. R.; LANGONI, H.; RIBEIRO, E. F.; AZEVEDO, A. E.; BONFIN, A. C. Early embryonic death in mares: clinical and hormonal aspects. In: INTERNATIONAL SYMPOSIUM ON EQUINE REPRODUCTION, 6., 1994, Caxambu, 1994.

PARAKARAINEN, T.; AHTIAINEN, P.; ZHANG, F.; RULLI, S.; POUTANEN, M.; HUHTANIEMI, I. Extragonadal LH/hCG action- not time to rewrite textbooks. Molecular and Cellular Endocrinology, v. 269, p. 9-16, 2007. 
PARKINGTON, H. C. Electrical properties of the costo-uterine muscle of the guinea-pig. Journal of Physiology, v. 335, p. 15-27, 1983.

PATE, J. L.; CONDON, W. A. Effects of serum and lipoproteins on steroidogenesis in cultured bovine luteal cells. Molecular Cellular Endocrinology, v. 28, p. 551-562, 1982.

PATTON, P. E.; STOUFFER, R. L. Current understanding of corpus luteum of women and non-human primates. Clinical Obstetric Gynecology, v. 34, p. 127-143, 1991.

PEDREROS, M.; RATTO, M.; GUERRA, G. Expression of functional melatonin $\mathrm{MT}_{1}$ receptors in equine luteal cells: in vitro effects of melatonin on progesterone secretion. Reproduction, Fertility and Development, v. 23, p. 417-423, 2011.

PELEHACH, L. M.; GREAVES, H. E.; PORTER, M. B.; DESVOUSGES, A.; SHARP, D. C. The role of estrogen and progesterone in the induction and dissipation of uterine edema in mares. Theriogenology, v. 58, p. 441-444, 2002.

PIERSON, R. A. Foliculogenesis and ovulation. In: MCKINNON, A.O.; VOSS, J.L. Equine reproduction. [S.l]: Williams e Wilkins, 1993. p. 161-171.

PINTO, C. R. F. Progestagens and Progesterone In: MCKINNON, A. O.; SQUIRES, E. L.; VAALA, W. E.; VARNER, D. D. Equine reproduction. 2. ed. [S.l.]: Wiley Blackwell, 2011. p. 1811-1819.

PLOTKA, E. D.; FOLEY, C. W.; WITHERSPOON, D. M.; SCHMOLLER, G. C.; GOESTSCH, D. D. Periovulatory changes in peripheral plasma progesterone and oestrogen concentrations in the mare. American Journal of Veterinary Research, v. 36, p. 1359-1362, 1975.

PYCOCK, J. F. Breeding management of the problem mare In: SAMPER, J. C. Equine breeding management and artificial insemination. 2. ed. St Louis: W.B. Saunders Company, 2009. p.139-164.

PYCOCK, J. F. Ultrasonography. In: MCKINNON, A. O.; SQUIRES, E. L.; VAALA, W. E.; VARNER, D. D. Equine reproduction. 2. ed. [S.l.]: Wiley Blackwell, 2011. p. 1914-1921.

PYCOCK, J. F.; DIELEMAN, S.; DRIFJHOUT, P.; VAN DER BRUG, Y.; OEI, C.; VAN DER WEIJDEN, G. C. Correlation of plasma concentrations of progesterone and estradiol with ultrasound characteristics of the uterus and duration of estrous behavior in the cycling mare Reproduction in Domestic Animals, v. 30, p. 224, 1995.

PYCOCK J. F.; NEWCOMBE, J. R. The effect of the gonadotrophin-releasing hormone analog, buserelin, administered in diestrus on pregnancy rates and pregnancy failure in mares. Theriogenology, v. 46, p. 1097-1101, 1996.

RANTANEN, N. W.; EWING, R.L. Principles of ultrasound application in animals. Veterinary Radiology, v. 22, n. 5, p.196-203, 1981.

RAO, C. V. Multiple novel roles of luteinizing hormone. Fertility and Sterility, v. 76, p. 1097-1100, 2001. 
RAO, C. V.; ALSIP, N. L. Use of the rat model to study hCG/LH effects on uterine blood flow. Seminars in Reproductive Medicine, v. 19, p. 75-85, 2001.

RAO, C. V.; LEI, Z. M. The past, present and future of nongonadal LH/hCG actions in reproductive biology and medicine review. Molecular and Cellular Endocrinology, v. 269, n. 1, p. 2-8, 2007.

REDMER, D. A.; REYNOLDS, L. P. Angiogenesis in the ovary. Reviews of Reproduction, v. 1, p.182-192, 1996.

RESHEF, E.; LEI, Z. M.; RAO, CH. V.; PRIDHAM, D. D.; CHEGINI, N.; LUBORSKY, J. L. The presence of gonadotropin receptors in nonpregnant human uterus, human placenta, fetal membranes, and decidua. Journal of Clinical Endocrinology Metabolism, v. 70, p. 421-430, 1990.

REYNOLDS, L.; GRAZUL-BILSKA, A.; REDMER, D. Angiogenesis in the corpus luteum. Endocrine , v. 12, p. 1-9, 2000.

REYNOLDS, L.; KILLILEA, S. D.; GRAZUL-BILSKA, A. T.; REDMER, D. A. Mitogenic factors of corpora lutea. Progress in Growth Factor Research, v. 5, p. 159-175, 1994.

REYNOLDS, L. P.; REDMER, D. A. Growth and development of the corpus luteum. Journal Reproduction Fertility, v. 54, p. 181-191, 1999, Supplement.

RICHARDS, J. S. Hormonal control of gene expression in the ovary. Endocrinology Reviews, v. 15, p. 725-751, 1994.

RICHARDS, J. S.; RUSSELL, D. L.; ROBKER, R. L.; DAJEE, M.; ALLISTON, T. N. Molecular mechanisms of ovulation and luteinization. Molecular and cellular endocrinology, $\mathrm{v}$. 145, n. 1-2, p. 47-54, 1998.

RILEY, C. M.; BEHRMAN, H. R. Oxygen Radicals and Reactive Oxygen Species in Reproduction. Proceedings of Society for Experimental Biology and Medicine, v. 198, p. 781-91, 1991.

RIZZO, A.; MUTINATI, M.; SPEDICATO, M.; MINOIA, G.; TRISOLINI, C.; PUNZI, S.; ROSCINO, M.T.; JIRILLO, F.; SCIORSCI, R. Thyreotropic effect of human chorionic gonadotrophin (hCG) in mares at estrus. Immunopharmacology and Immunotoxicology, v. 31, n. 2, p. 299-303, 2009.

ROBERTO DA COSTA, R. P.; BRANCO, V.; PESSA, P.; ROBALO SILVA. J.; FERREIRA-DIAS, G. Progesterone receptors and proliferating cell nuclear antigen expression in the equine luteal tissue. Journal of Reproduction Fertility Development, v. 17, p. 659-666, 2005.

ROBKER, R. L.; RUSSELL, D. L.; YOSHIOKA, S.; SHARMA, S. C.; LYDON, J. P.; O’MALLEY, B. W.; ESPEY, L. L. Ovulation: a multi-gene, multi-step process. Steroids, v. 65, n. 10-11, p. 559-570, 2000.

ROSER, J. F.; EVANS, J. W. Luteal luteinizing hormone receptors during the postovulatory period in the mare. Biology of Reproduction, v. 29, p. 499-510, 1983. 
ROSER, J. F.; KEIFER, B. L.; EVANS, J. W.; The development of antibodies to human chorionic gonadotrophin following its repeated injection in the cyclic mare. Journal of Reproduction and Fertility, v. 27, p. 173-179, 1979.

ROTCHILD, I. The regulation of the mammalian corpus luteum. Records Program Hormone Research , v. 37, p. 183-198, 1981.

RUEDA, B.; HENDRY, I.; HENDRY, W.; STORMSHAK, F.; SLAYDEN, O.; DAVIS, J. Decreased progesterone levels and progesterone receptor antagonists promote apoptotic cell death in bovine luteal cells. Biology of Reproduction, v. 62, p. 269-276, 2000.

SAHARREA, A.; VALENCIA, J.; BALCÁZAR, A. Premature luteal regression in goats superovulated with PMSG: effect of hCG or GnRH administration during the early luteal phase. Theriogenology, v.50, p.1039-1052, 1998.

SAMPER, J. C. Management and fertility of mares bred with frozen semen. Animal Reproduction Science, v. 68, p. 219-228, 2001.

SAMPER, J. C. Induction of estrus and ovulation: why some mares respond and others do not. Theriogenology, v. 70, n. 3, p. 445-447, 2008.

SANTOS, J.E., THATCHER, W. W., POOL, L., OVERTON, M.W. Effect of human chorionic gonadotropin on luteal function and reproductive performance of high-producing lactating Holstein dairy cows. Journal Animal Science, v.79, p. 2881-94, 2001.

SAWYER, H. R.; OLSON, P. N.; GORELL, T. A. Effects of progesterone on the oviductal epithelium in estrogen-primed prepubertal beagles: light and electron microscopic observations. American Journal of Anatomy, v. 169, p. 75-87, 1984.

SAYASITH, K.; BOUCHARD, N.; DORÉ, M.; SIROIS, J. Cloning of equine prostaglandin dehydrogenase and its gonadotropin-dependent regulation in theca and mural granulose cells of equine preovulatory follicles during the ovulatory process.

Reproduction, v. 133, p .455-466, 2007.

SCHMITT, E. J.;BARROS, C. M.; FIELDS, P. A.; FIELDS, M. J.; DIAZ, T.; KLUGE, J. M.; THATCHER, W.W. A cellular and endocrine characterization of the original and induced corpus luteum after administration of a gonadotropin-releasing hormone agonist or human chorionic gonadotropin on day five of the estrous cycle. Journal of Animal Science, v. 74, p. 1915-1929, 1996.

SEEDORF, U.; ELLINGHAUS, P.; ROCH NOFER, J. Sterol carrier protein 2. Biochim Byophis Acta, 1486, p,45-54, 2000.

SESSIONS, D.R.; REDDY, S.E.; VICK, M.M.; MURPHY, B.A.; FITZGERALD, B.P. Development of a model for inducing transient insulin resistance in the mare: Preliminary implications regarding the estrous cycle, Journal of Animal Science, v. 82, p.23212328, 2004. 
SEVINGA, M.; SCHUKKEN, Y. H.; HESSELINK, J. W.; JONKER, F. H. Relationship between ultrasonic characteristics of the corpus luteum, plasma progesterone concentration and early pregnancy diagnosis in Friesian mares. Theriogenology, v. 52, p. 585-592, 1999.

SHABANKAREH, H. K.; SEYEDHASHEMI, S. B.; TORKI, M.; KELIDARI, H.;

ABDOLMOHAMMADI, A. Effects of repeated administration of hCG on follicular and luteal characteristics and serum progesterone concentrations in eCG-superovulated Sajabi ewes. Tropical Animal Health Production, v. 44, n. 1, p. 1865-1871, 2012.

SHARP, D. C. Maternal recognition of pregnancy. In: MCKINNON, A. O.; VOSS, J. L. Equine reproduction. Philadelphia: Lea and Febiger, 1993. p. 486-493.

SHARP, D. C. The early fetal life of the equine conceptus. Animal Reproduction Science, v. 60-61, p. 679-689, 2000.

SHARP, D. C. Vernal transition into the breeding season. In: MCKINNON, A. O.; SQUIRES, E. L.; VAALA, W. E.; VARNER, D. D. Equine reproduction. 2. ed. [S.l.]: Wiley Blackwell, 2011. p. 1704-1715.

SHARP, D. C.; DAVIS, S. D. Vernal transition. In: MCKINNON, A.O.; VOSS, J.L.Equine Reproduction. Philadelphia: Lea and Febiger, 1993. p. 133-143.

SHIDELER, R. K.; SQUIRES, E. L.; VOSS, J. L.; EIKENBERRY, D. J.; PICKETT, B. W. Progestogen therapy of ovariectomized pregnant mares. Journal of Reproduction Fertility, v. 32, p. 459-464, 1982.

SIANANGAMA, P. C.; RAJAMAHENDRAN, R. Effect of human chorionic gonadotropin administered at specific times following breeding on milk progesterone and pregnancy rates in cows. Theriogenology, v. 38, p. 85-96, 1992.

SIDDIQUI, M. A. R.; GASTAL, E. L.; GASTAL, M. O.; BEG, M. A.; GINTHER, O. J. Effect of hCG in the Presence of hCG Antibodies on the Follicle, Hormone Concentrations, and Oocyte in Mares, Reproduction in Domestic Animals, v. 44, p. 474-479, 2009.

SILVA, L. A. Uterine and ovarian vascular and architectural changes in equids and bovids; with emphasis on effect of the conceptus. 2009. $282 \mathrm{f}$. Dissertação (Doutorado em Filosofia), University of Florida, Gainesville, 2009.

SILVA, L. A.; GASTAL, E. L.; BEG, M. A.; GINTHER, O. J.Changes in vascular perfusion of the endometrium in association with changes in location of the embryonic vesicle in mares.

Biology of Reproduction, v. 72, p. 755-761, 2005.

SILVA, L. A.; GASTAL, E. L.; GASTAL, M. O.; BEG, M. A.; GINTHER, O. J. Relationship between vascularity of the preovulatory follicle and establishment of pregnancy in mares, Animal Reproduction, v. 3, n. 3, p. 339-346, 2006.

SILVA, L. A.; GINTHER, O. J. An early endometrial vascular indicator of completed orientation of the embryo and the role of dorsal endometrial encroachment in mares.

Biology of Reproduction, v.74, p.337-343, 2006. 
SIROIS, J.; DORE, M. The late induction of prostaglandin G/H synthase-2 in equine preovulatory follicles supports its role as a determinant of the ovulatory process. Endocrinology, v. 138, p. 4427-4434, 1997.

SIROIS, J.; SIMMONS, D. L.; RICHARDS, J. S. Hormonal regulation of messenger ribonucleic acid encoding a novel isoform of prostaglandin endoperoxide $H$ synthase in rat preovulatory follicles. The Journal of Biological Chemistry, v. 267, p. 1158611592, 1992.

SKARZYNSKI, D. J.; FERREIRA-DIAS, G.; OKUDA, K. Regulation of luteal function and corpus luteum regression in cows: hormonal control, immune mechanisms and intercellular communication. Reproduction in Domestic Animals, v. 43, p. 57-65, 2008. Supplement, 2.

SKARZYNSKI, D. J.; OKUDA, K. Sensitivity of bovine corpora lutea to prostaglandin F2a is dependent on progesterone, oxytocin and prostaglandins. Biology of Reproduction, $v$. 60, p. 1292-1298, 1999.

SOUZA, F. A. C. S. Efeitos da gonadotrofina coriônica humana (hCG) sobre as características reprodutivas de fêmeas equinas candidatas a receptoras de embriões. 2006. 64 f. Dissertação (Mestrado em Reprodução Animal)- Faculdade de Medicina Veterinária e Zootecnia, Universidade de São Paulo, Pirassununga, 2006.

SQUIRES, E. L. Hormonal Manipulation of the Mare: A Review. Journal of Equine Veterinary Science, v. 28, n. 11, p. 627-634, 2008.

SQUIRES, E. L. Progesterone. In: MCKINNON, A. O.; VOSS, J. L. Equine reproduction. Philadelphia: Lea and Febiger, 1993. p. 57-64.

SQUIRES, E. L.; MCKINNON, A. O.; CARNEVALE, E. M.; MORRIS, R.; NETT, T. M. Reproductive characteristics of spontaneous single and double ovulating mares and superovulated mares. Journal of Reproduction Fertility Supplement, v. 35, p. 399403, 1987.

STABENFELDT, G. H.; HUGHES, J. P.; EVANS, J. W. Ovarian activity during the estrous cycle of the mare. Endocrinology, v. 90, p. 1379-1384, 1972.

STENMAN, U. H.; TIITINEN, A.; ALFTHAN, H.; VALMU, L. The classification, functions and clinical use of different isoforms of hCG. Human Reproduction, v. 12, p. 769-784, 2006.

STEVENSON, J. S.; TIFFANY, S. M.; INSKEEP, E. K. Maintenance of pregnancy in dairy cattle after treatment with human chorionic gonadotropin or gonadotropin-releasing hormone 1. Journal of Dairy Science, v. 91, n. 8, p. 3092-3101, 2008.

STOCCO, C.; TELLERIA, C.; GIBORI, G. The molecular control of corpus luteum formation , function , and regression. Endocrine Reviews, v. 28, n. 1, p. 117-149, 2007.

STOUFFER, R. L. The functions and regulation of cell populations comprising the corpus luteum during the ovarian cycle. In: ADASHI, E. Y.; LEUNG, P. C. K. The ovary. New York: Raven Press. 2004. p. 169-184. 
STOUFFER, R. L.; MARTÍNEZ-CHEQUER, J. C.; MOLSKNESS, T. A.; XU, F.; HAZZARD, T. M. Regulation and action of angiogenic factors in the primate ovary. Archives of Medical Research, v. 32, p. 567-575, 2001.

STOUT, T. A. E. The early pregnancy in the mare. In: SAMPER, J.C. Equine breeding management and artificial insemination. 2. ed. [S.I.]: Saunders, 2009. p. 223-239.

STOUT, T. A. E. Prostaglandins. In: MCKINNON, A. O.; SQUIRES, E. L.; VAALA, W. E.; VARNER, D. D. Equine Reproduction. 2. ed. [S.l.]: Wiley Blackwell, 2011. p.1642-1647.

STROUD, B.; CALLESEN, H. IETS statement on worldwide ET statistics for 2010. Animal Reproduction, v. 9, n. 3, p. 210-216, 2012.

SULLIVAN, J. J.; PARKER, W. G.; LARSON, L. L. Duration of estrus and ovulation time in nonlactating mares given human chorionic gonadotropin during three successive estrous periods. Journal of American Veterinary Medicine Association, v. 162, p. 895-898, 1973.

SWANN, R. T.; BRUCE, N. W. Oxygen consumption, carbon dioxide production and progestagen secretion in the intact ovary of the day-16 pregnant rat. Journal of Reproduction and Fertility, v. 80, p. 599-605, 1987.

TAMANINI, C.; DE AMBROGI, M. Angiogenesis in developing follicle and corpus luteum. Reproduction in Domestic Animals, v.39, p. 206-216, 2004.

TEZUKA, N.; ALI, M.; CHWALISZ, K.; GARFIELD, R. E. Changes in the transcripts encoding calcium channel subunits of rat myometrium during pregnancy. American Journal of Physiology, v. 269, p. C1008-C1017, 1995.

THATCHER, W. W.; BILBY, T. R.; BARTOLOME, J. A.; SILVESTRE, F.; STAPLES, C. R.; SANTOS, J. E. Strategies for improving fertility in the modern dairy cow.

Theriogenology, v. 65, p. 30-44, 2006.

THOMPSON, D. L. Anestrus In: MCKINNON, A. O.; SQUIRES, E. L.; VAALA, W. E.; VARNER, D. D. Equine reproduction. 2. ed. [S.l.]: Wiley Blackwell, 2011. p. 1696-1703.

TINKANEN, H. The role of vascularization of the corpus luteum in the short luteal phase studied by Doppler ultrasound. Acta Obstetrics Gynecology Scandinavia, v. 73, p. 321323, 1994.

TORTONESE, D. J.; GREGORY, S. J.; EAGLE, R. C.; SNEDDON, C. L.; YOUNG, C. L.; TOWNSEND, J. The equine hypophysis: a gland for all seasons. Reproduction Fertility and Development, v. 13, p. 591-597, 2001.

TOTH, P.; LI, X.; RAO, C. V.; LINCOLN, S. R.; SANFILIPPO, J. S.; SPINNATO II, J. A.; YUSSMAN, M. A. Expression of functional human chorionic gonadotropin/human luteinizing hormone receptor gene in human uterine arteries. Journal. of Clinical Endocrinology Metabolism, v. 79, p. 307-315., 1994 
TOWNSON, D. H.; PIERSON, R. A.; GINTHER, O. J. Characterization of plasma progesterone concentrations for two distinct luteal morphologies in mares. Theriogenology, v. 32, n. 2, p. 197-204, 1989.

TROEDSSON, M. H. T.; LIU, I. K. M.; ING, M. Multiple site electromyography recordings on uterine activity following an intrauterine bacterial challenge in mares susceptible and resistant to chronic uterine infection. Journal of Reproduction Fertility, v. 99, p. 307312, 1993.

TUCKER, K. E.; CLEAVER, B. D.; SHARP, D. C. Does resumption of follicular estradiol synthesis during vernal transition in mares involve a shift in steroidogenic pathways? Biology of Reproduction, v. 48, p. 188, 1993. Supplemento 1.

URQUIETA, B.; DURÁN, M. C.; COLOMA, I.; PARRAGUEZ, V. H. hCG-Induced Ovulation in Thoroughbred Mares Does Not Affect Corpus luteum Development and Function During Early Pregnancy, Reproduction in Domestic Animals, v. 44, p. 859-864, 2009.

VANDERWALL, D.K. Progesterone . In: MCKINNON, A. O.; SQUIRES, E. L.; VAALA, W. E.; VARNER, D. D. Equine reproduction. 2. ed. [S.l.]: Wiley Blackwell, 2011. p. 1637-1641.

VAN NIEKERK, C. H.; MORGENTHAL, J. C.; GERNEKE, W. H. Relationship between morphology of and progesterone production by the corpus luteum of the mare. Journal Reproduction Fertility, v. 23, p. 171-175, 1975. Supplemento.

VEGA, M.; URRUTIA, L.; IÑIGUEZ, G.; GABLER, F.; DEVOTO, L.; JOHNSON, M.C. Nitric oxide induces apoptosis in the human corpus luteum in vitro. Molecular Human Reproduction, v.6, n.8, p.681-687, 2000.

VERHAGE, H. G.; FAZLEABAS, A. T. The in vitro synthesis of estrogen-dependent proteins by the baboon (Papio anubis) oviduct. Endocrinology, v. 123, p. 552-558, 1988.

VOLLER, B. E.; PARRY-WEEKS, L. C.; HOLTAN, D. W. The effect of Regu-Mate, a synthetic progestin, on early pregnancy maintenance, conceptus growth, and corpora lutea development in pregnant pony mares. Equine Veterinary Science, v. 11, p. 46 -50, 1991.

WASEDA, T.; MAKINODA, S.; WATANABE, Y.; SASAKURA, C.; IMAFUKU, N.;HIROSAKI, N. Hemodynamic response of ovarian artery after hCG injection. Molecular Cell

Endocrinology, v. 202, p. 71-75, 2003.

WATSON, E. D.; SERTICH, P.L. Secretion of prostaglandins and progesterone by cells from corpora lutea of mares. Journal of Reproduction Fertility, v. 88, p. 223-229, 1990.

WATSON, E. D. Progesterone and estrogen receptor distribution in the endometrium of the mare. Theriogenology, v. 38, p. 575-580, 1992.

WATSON, E. D. Compartmentalization of steroidogenesis by the equine corpus luteum. Theriogenology, v. 53, p. 1459-66, 2000. 
WATSON, E. D.; AL-ZI'ABI, M. O. Characterization of morphology and angiogenesis in follicles of mares during spring transition and the breeding season. Reproduction, $\mathrm{v}$. 124, p. 227-234, 2002.

WATSON, E. D.; BAE, S.; AL-ZI, M. O.; HOGG, C. O. Expression of mRNA encoding insulinlike growth factor binding protein-2 (IGFBP-2) during induced and natural regression of equine corpora lutea. Theriogenology, v. 64, n. 6, p. 1371-1380, 2005.

WEEDMAN, B. J.; KING, S. S.; NEUMANN, K. R.; NEQUIN, L. G. Comparison off circulating estradiol -17 and folliculogenesis during the breeding season, autumn transition and anestrus in the mare. Journal of Equine Veterinary Science, v. 13, p. 502-505, 1993.

WILLMANN, C.; BUDIK, S.; WALTER, I.; AURICH, C. Influences of treatment of early pregnant mares with the progestin altrenogest on embryonic development and gene expression in the endometrium and conceptus. Theriogenology, v. 76, n. 1, p. 61-73, 2011.

WILLMANN, C.; SCHULER, G.; HOFFMANN, B.; PARVIZI, N. Effects of age and altrenogest treatment on conceptus development and secretion of $\mathrm{LH}$, progesterone and eCG in early-pregnant mares. Theriogenology, v. 75, n. 3, p. 421-428, 2011.

WILSON, C.; DOWNIE, C.; HUGHES, J.; ROSER, J. Effects of repeated hCG injections on reproductive efficiency in mares. Journal of Equine Veterinary Science, v. 10, n. 4, p. 301-308, 1990.

WILTBANK, M. C.; DYSKO, R. C.; GALLAGHER, K. P.; KEYES, P. L. Relationship between blood flow and steroidogenesis in the rabbit corpus luteum. Journal of Reproduction Fertility, v. 84, p. 513-20, 1988.

WONG, W. Y. W.; RICHARDS, J. S. Evidence for two antigenically distinct molecular weight variants of prostaglandin H synthase in the rat ovary. Molecular Endocrinology, v. 5, p. 1269-1279, 1991.

WOODS, G. L.; HILLMAN, R. B.; SCHLAFER, D. H. Recovery and evaluation of embryos from normal and infertile mares. Cornell Veterinary Journal, v. 76, p. 386-394, 1986.

XIA, P.; AIELLO, L. P.; ISHII, H.; JIANG, Z. Y.; PARK, D. J.; ROBINSON, G. S. Characterization of vascular endothelial growth factor's effect on the activation of protein kinase $C$, its isoforms, and endothelial cell growth. Journal of Clinical Investigation, v. 98, p. 2018 2026, 1996.

ZALUD, I.; KURJAK, A. The assessment of luteal blood flow in pregnant and nonpregnant women by transvaginal Color Doppler. Journal of Perinatology Medicine, v. 18, p. 21521, 1990.

ZAVY, M. T. An investigation of the uterine luminal environment of non-pregnant and pregnant pony mares. Journal of Reproduction Fertility, v. 27, p. 403-411, 1979, Supplemento 27.

ZAVY, M. T.; SHARP, D. C.; BAZER, F. W.; FAZLEABAS, A.; SESSIONS, F.; ROBERTS, R. M. Identification of stage-specific and hormonally induced polypeptides in the uterine 
protein secretions of the mare during the oestrous cycle and pregnancy. Journal of Reproduction and Fertility, v. 64, p. 199-207, 1982.

ZAVY, M. T.; VERNON, M. W.; ASQUITH, R. L.; BAZER, F. W.; SHARP, D. C. Effect of exogenous gonadal steroids and pregnancy on uterine luminal prostaglandin $\mathrm{F}$ in mares. Prostaglandins, v. 27, n. 2, p. 311-320, 1984.

ZHENG, J.; REDMER, D. A.; REYNOLDS, L. P. Vascular development and heparin-binding growth factors in the bovine corpus luteum at several stages of the estrous cycle, Biology of Reproduction, v. 49, p. 1177-1189, 1993.

ZIECIK, A. J.; STANCHEV, P. D.; TILTON, J. E. Evidence for the presence of luteinizing hormone/human chorionic gonadotropin-binding sites in the porcine uterus.

Endocrinology, v. 119, p. 1159-1163, 1986.

ZIECIK, A. J.; STANCHEV, P. D.;TILTON, J. E. An Overview of the Past, Present, and Future of Nongonadal LH/hCG Actions in Reproductive Biology and Medicine. Seminars in Reproductive Medicine, v. 19, n. 1, p. 7-17, 2001.

ZIECIK, A. J.; KACZMAREK, M. M.; BLITEK, A.; KOWALCZYK, A. E.; LI, X.; RAHMAN, N. A. Novel biological and possible applicable roles of LH / hCG receptor. Molecular and Cellular Endocrinology, v. 269, p. 51-60, 2007.

ZIECIK, A. J.; DERECKA-RESZKA, K.; RZUCIDLO, S. J. Extragonadal gonadotropin receptors, their distribution and function. Journal of Physiology and Pharmacology, v. 43 , p. 33-49, 1992.

ZUÑIGA, M.P. Fertilidad en yeguas fina sangre de carrera, posterior al uso de gonadotropina corionica humana. 2005. 47f. Memoria para optar al Titulo Profesional de Medico Veterinario, Universidad de Chile, Facultad de Ciencias Veterinarias y Pecuarias.Santiago. Chile, 2005.

ZYGMUNT, M.; HERR, F.; KELLER-SCHOENWETTER, S.; KUNZI-RAPP, K.; MUNSTEDT, K.; RAO, C. V. Characterization of human chorionic gonadotropin as novel angiogenic factor. Journal of Clinical Endocrinology Metabolism, v. 87, p. 5290-5296, 2002. 